


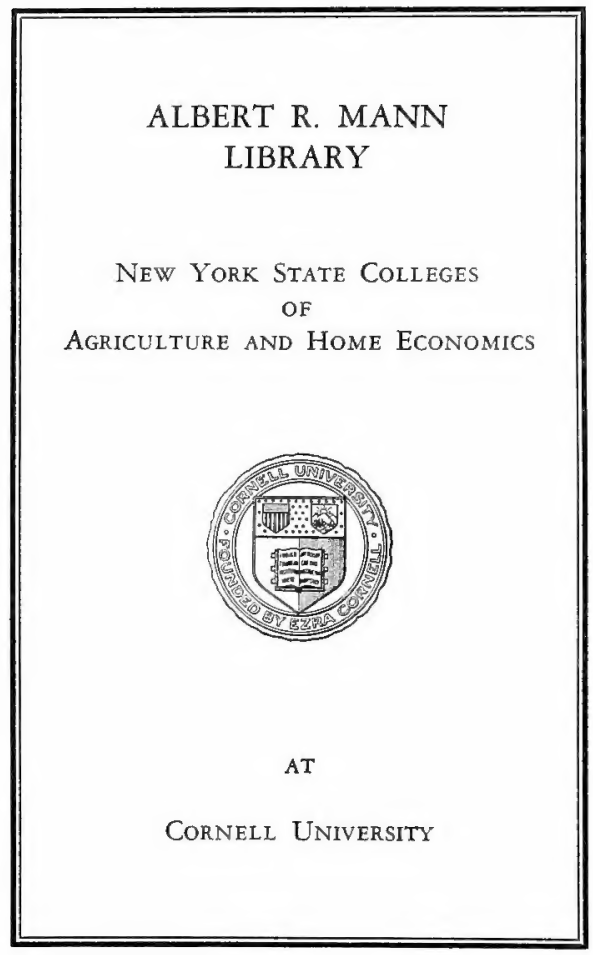




\section{Cornell University Library}

QL 430.5.C41B29

Experiments in the breeding of cerions,

||||||||||||||||||||||||||||||||||||||||||||||||||||||||||||

31924003415431 mann 


\section{Cornell University Library}

The original of this book is in the Cornell University Library.

There are no known copyright restrictions in the United States on the use of the text.

http://www.archive.org/details/cu31924003415431 






\section{DEPARTMENT OF MARINE BIOLOGY \\ $\mathrm{OF}$}

THE CARNEGIE INSTITUTION OF WASHINGTON

ALFRED G. MAYOR, DIRECTOR

VOLUME XIV

EXPERIMENTS IN THE BREEDING OF CERIONS

BY

PAUL BARTSCH

Curator of Marine Invertebrates, United States National Museum

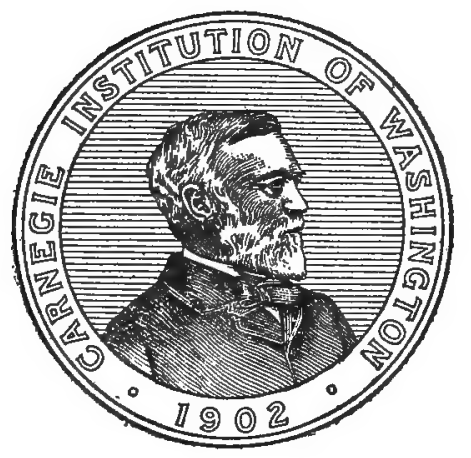

WASHINGTON, D. C.

Published by the Carnegie Institution of Washington 1920 
CARNEGIE INSTITUTION OF WASHINGTON

Publication No. 282

PRESS OF GIBSON BROTHERS, INC.

WASHINGTON, D. C. 


\title{
EXPERIMENTS IN THE BREEDING OF CERIONS.
}

\author{
Bx Patu Bartsch.
}

In 1912, by invitation from the Director of the Marine Biological Laboratory of the Carnegie Institution of Washington, and through the courtesy of the Secretary of the Smithsonian Institution, I had an opportunity to visit the Bahamas and to make personal observations upon the Cerions on New Providence and on Andros in the region of South Bight.

On this expedition we found that Cerions were very abundant wherever they occur, that they live close to the seashore, but nevertheless remain well beyond the reach of the ocean spray. They never, therefore, live outside of the hurricane rampart of the exposed shores. They are usually on the lowland flats, but under favorable circumstances may climb the hills, for example Driggs Hill or Morgan's Bluff at Andros and the sea bluff at Jeremie, Haiti. This partiality to the coast lands is probably responsible for their discontinuous distribution, practically resulting in the formation of isolated colonies, and a great number of closely related forms scattered over the entire Archipelago of the Bahamas.

By taking material gathered from such a colony and noting all measurable characters presented by its members, one obtains a mode different from that which may be secured in a similar manner from an adjacent colony. Each colony, therefore, presents certain slight characters by which we can distinguish its members from those of other colonies.

The question arises, are the forms in the various colonies fixed forms; that is, will generation after generation yield the same mode in measurements, or will changes in the local environment from season to season affect the developing organisms to such an extent as to produce an unending series of slight variations? These were the problems that called for a solution. The hope of throwing some light upon these questions prompted the breeding experiments which were started in 1912 and have been followed up ever since, and upon which the following reports have been published from time to time:

Planting Bahama Cerions upon the Florida Keys, Year Book No. 11 of the Carnegie Institution of Washington, 1912, pp. 129-131.

Report of Results of the Planting of Bahama Cerions on the Florida Keys, Year Book No. 12 of the Carnegie Institution of Washington, 1913, pp. 169-172.

Preliminary Report on the Bahama Cerions planted on the Florida Keys, Year Book No. 13 of the Carnegie Institution of Washington, 1915, p. 196.

Experiments with Cerions in the Florida Keys, Smithsonian Miscellaneous Collections No. 6,1915 , illustrations $38-40$. 
Report on the Bahama Cerions planted on the Florida Keys, Carnegie Inst. Wash. Pub. No. 212, 1915, pp. 203-212, plates 1-8.

Report on Bahama Cerions planted on the Florida Keys, Year Book No. 14 of the Carnegie Institution of Washington, 1915, pp. 194-196.

Report on the Bahama Cerions planted on the Florida Keys, Annual Report of the Director of Department of Marine Biology, Carnegie Institution of Washington, extract from Year Book No. 15 for the year 1916, pp. 179-182.

Visit to the Cerion Colonies in Florida, Smithsonian Miscellaneous Collections, vol. 66, No. 17, 1917, pp. 41-44.

A Visit to the Cerion Colonies in Florida, Smithsonian Miscellaneous Collections, vol. 68, No. 12, June, 1918, pp. 48-49.

The Florida Keys were considered to be a favorable region into which these Bahama forms might be introduced, for these keys stretch for more than 240 miles from Virginia Key on the north to the Dry Tortugas in the Gulf of Mexico, and present quite a range in climatic factors and vegetation. Many of them harbor an indigenous species, Cerion incanum (Binney), which, however, is quite unrelated to those that have been introduced. Furthermore, in selecting sites for our colonies we aimed to avoid placing the introduced forms where the native species existed. Colonies of 500 each were planted on the keys in 1912, as will be seen in the following pages. The shells of the mollusks planted were marked by two parallel file cuts made across two or more ribs. This method of marking has proved very satisfactory.

Two Bahama species were planted in the first introduction. These are what are now termed Cerion casablanca, a new species gathered in the neighborhood of the White House, which was our laboratory during the 1912 cruise, and which is situated between Sharp Rock Point and Driggs Hill, on the southeast side of South Bight, Andros Island. This species has been referred to in the previous reports as the White House type of Cerion. The material of the other species, which I am calling Cerion viaregis in the present paper, was gathered along King's Road, Bastion Point, on the northeast side of South Bight, Andros. The mollusks from this region have been referred to in the past reports as the King's Road type of Cerions. In addition to these two, 73 specimens of a small mottled Cerion (species ?) from Andros were planted on Bird Key. These have since disappeared without leaving any trace of progeny. They will therefore not be referred to again.

An additional importation of 500 specimens of Cerion viareais gathered in 1914 was planted on Loggerhsad Key (Colony F) on June 9 of the same year. On the same date a second colony of mottled Cerions, Cerion (species ?), gathered at Spring Hill, Nassau, by Dr. Mayor in 1914, was made on Loggerhead Key. This colony has also disappeared, a few dead shells only remaining, so it also may be disregarded in our discussion. Our unfortunate experience with the painted Cerions in the Tortugas may indicate that this group does not find the environmental conditions suitable for its maintenance. 
Another introduction was made on Loggerhead Key in 1915. This consisted of 800 specimens of Cerion crassilabris ("Shuttleworth" Sowerby) gathered by Dr. Mayor at Ballena Point, near Guanica Bay, Porto Rico. This will be referred to later as Colony L.

The last introduction was made in 1916, and forms Colony $\mathrm{N}$ on Loggerhead Key. This colony consists of 8,317 specimens of Cerion uva (Linnæus) gathered by Dr. Ralph Arnold at Curaçao, Netherlands West Indies.

Some of these colonies have now produced the second generation of Florida-grown offspring, and it is deemed desirable to put on record a complete account of the results so far attained in these breeding experiments. We shall consider in rotation the colonies of the different species from the north to the south, and give tables of measurements which will show the altitude and the greater and lesser diameter of the specimens. We will also give photographs of all the specimens measured. The numbers given to the specimens measured will also be employed in the photographs, so that the two can readily be connected. It is deemed desirable to publish this large number of figures because the specimens discussed could not be retained as Museum records, for future observations, but had to be used for further breeding. Our photographs, therefore, must take the place of the specimen itself, and convey an idea of whatever variation in outline and sculpture the material grown in Florida may present.

I have selected a larger check series (100 specimens) than in my 1915 report, in which only 10 were used. This was deemed desirable in order to show more definitely the range of variations. This check series of 100 was taken at random from a large number of individuals and it is believed that it well represents all limits of variations.

Cerions may be found on the ground, under the edges of stones, or on top of them, among dead leaves or upon blades of grass, dead stumps, the bases of trees, and on low bushes. They never ascend to any considerable height, for we have rarely found them beyond the reach of the hand above the surface of the ground. When Cerions occupy an exposed position they attach themselves to the support by a thin epiphragm which serves the double purpose of fixing them to the support and preventing desiccation; thus sealed up they appear to be able to estivate for a considerable length of time, and under such conditions are apparently not harmed, even when exposed to the blazing tropical sun for a prolonged period.

Observations made during the years which have intervened between 1912 and 1919 lead me to believe that Cerions are largely nocturnal. They are most active on misty nights. At such times the animals may be seen on the ground, where they dig, with about one-fourth to threefourths of the animal and shell buried below the surface. Animals 
gathered at such times and examined prove to be filled with fungal mycelia, which evidently form a very large part of their food. The specimens kept in captivity, however, have shown a greater range of food selection; paper seems to be particularly to their liking, although they will also feed upon moist cornmeal and other vegetable products; I feel quite certain, however, that in their natural environment their main diet is fungal.

Unlike many other mollusks, instead of hiding away in moist, cool places with the approach of the dry, hot day, they leave their submerged position for a more elevated one, and thus placed they remain until the conditions are again favorable for another foraging expedition. When moving about they carry the shell almost horizontally sloping backward and pointing slightly to the right.

Mating takes place on the ground. All the specimens which I have found in copulation were discovered in the early morning when the conditions of moisture were ideal for Cerion activities. The mating process is not a reciprocal one; that is, an animal is not actively male and female at the same time, but one functions as male and the other as female. The everted male organ is exceedingly long, attaining a length of fully an inch and a half when completely extended. When thus exposed, it reminds one strongly of a curved, flattened, white bristle.

The eggs appear to be deposited at the base of tufts of grass beneath the surface of the ground and, judging from many gatherings of the young in such positions, one is led to believe that a single egg only is deposited at a time. I have never found more than 6 young Cerions (usually 1 to 4 ) at the base of a single small tuft of grass, and these always in different stages of growth, indicating rather long intervals between oviposition. It is hoped that the experiments now in progress in my conservatory will throw definite light upon this point.

I have never found above ground young mollusks having the nepionic whorls only, and by far the larger number of those having attained three postnepionic whorls were dug from the sand about tufts of grass. It is only occasionally that one of this size seeks the characteristic elevated position of the parents.

Our experiments have shown that it takes between 2 and 3 years to produce a new generation of Cerions. We may therefore consider this the time required for an individual to reach full maturity in its development. No definite data are at hand so far to determine the age which Cerions may attain, but many (probably most) of the specimens transplanted from the Bahamas in 1912 are still in good condition, if not destroyed by fire or crabs. 


\section{A COMPARATIVE ANATOMICAL DISCUSSION OF THE FIVE SPECIES OF CERIONS INVOLVED IN THE BREEDING EXPERIMENTS.}

It was deemed desirable that we should have some knowledge of the anatomical structures of the soft parts of the 5 species of Cerions which have been used in our breeding experiments. For that purpose a goodly number of specimens of each species was carried north this year, properly expanded, killed, decalcified, and the anatomical characters subjected to close scrutiny. In the making of these dissections and drawings I have had the assistance of Dr. G. Dallas Hanna, one of my students and former associates.

The 5 species in question are the native species, Cerion incanum (Binney); the specimens used for dissection came from Porgee Key; Cerion uva (Linnæus) from Curaçao; Cerion crassilabris ("Shuttleworth" Sowerby) from Ballena Point, Guanica Bay, Porto Rico; Cerion casablance Bartsch from the White House region, Andros, to which we have referred as the "White House type Cerion" in the past reports, and Cerion viaregis Bartsch from the King's Road, Bastian Point, Andros, referred to in previous reports as the King's Road type Cerion.

Externally no differences worthy of notice excepting shell characters were discovered in these 5 types.

Tentacles and eye-stalks are developed in the manner of all Pulmonates. The locomotive disk, pedal groove, and caudal mucous pore are absent. The skin is covered with a series of white lines, of which those radiating from the mantle collar over the propodium and mesopodium are the most pronounced. These lines are crossed by connecting lines which produce an irregular reticulated pattern. The spaces inclosed in the meshes are dark gray to black on the top of the head, lighter on the sides and on the back of the foot. The genital opening is situated on the right side, beneath and slightly behind the eye-stalk; its orifice is not marked externally by a distinct structure or color pattern in the specimens examined. The breathing pore is opposite the posterior angle of the aperture of the shell. The anus and nephridiopore are on the right side and in contact with the breathing pore.

The mouth is situated at the usual position, on the ventral side of the head. Immediately behind this is the broad opening to the pedal cavity. The pedal cavity narrows quickly and forms part of the inner floor of the body cavity as a membranous duct.

The jaw is more or less strongly arched and provided with a median projection on the concave margin. The latter is scarcely perceptible in Cerion incanum and Cerion crassilabris, but is strongly marked in Cerion viaregis. No vertical markings were noticed in any of the specimens examined and concentric lines when present are very faint. 
Cerion uva is stated by some writers to be without this median projection, but the specimens examined did not agree with this dictum.

The radula presents some interesting variations in the 5 species under consideration. The number of longitudinal tooth rows appears to be practically constant. Cerion uva has 20-1-20, Cerion viaregis 22-1-22, Cerion crassilabris 23-1-23, Cerion casablance 25-1-25, Cerion incanum 27-1-27. These figures represent the rows which can be readily counted. The marginal teeth become mere plates at the extreme lateral margin, especially so in Cerion viaregis and Cerion crassilabris. These plates terminate as irregularly shaped masses which do not appear to be arranged in definite rows. It is therefore somewhat difficult to determine the exact number that can be actually counted in a given species, and this may account for slight differences reported for the same species by different observers. The markings on the marginal teeth can often not be made out with clearness; they appear to be quadrangular, basal in most cases. There is a gradual transition from laterals into the marginal beginning with about the tenth tooth. The laterals are normally bifid with the inner cusp large and rounded and the outer one much smaller and also rounded, but in Cerion casablancoe the smaller one is absent, though a few of the transitional teeth, both laterals and marginals, show two cusps. The lateral teeth are uniformly about twice as long as wide and are placed slightly obliquely away from the rachidian tooth. The rachidian tooth presents considerable difference in the different species. In Cerion crassilabris there are three cusps, the central one appearing to be placed on a lower level than the outside cusps. This same condition seems to obtain in the laterals, the outer cusps being above the inner. In Cerion viaregis there is but a single large rounded central cusp. In Cerion casablancee and Cerion incanum two minute projections are found bordering the median cusp. In Cerion uva the rachidian tooth is broader than long, while in all the other species it is about twice as long as broad. In this, too, the development of the lateral cusps is enormous.

The buccal mass differs little from the usual structure in Pulmonates. The esophagus enters the top of the posterior portion. The two salivary ducts discharge on each side of the esophagus at the junction of the latter with the buccal cavity. The esophagus and the salivary ducts pass beneath the cerebral commissure and over the buccal commissure. The buccal ganglia are firmly attached to the buccal mass, one on each side of the esophagus. The radula sack with the radula organ is situated just below the esophagus and projects backward from the distal end of the buccal mass. It extends from the radula sack, where it is attached, to the distal end of the buccal retractor, where it is inserted. In Cerion incanum the point of this insertion is in the center between the right and left branches of the buccal retractor, while in the other 
species examined it is inserted on its right branch. The buccal retractor (sometimes referred to as pharyngeal retractor) passes through the nerve ring above both the pedal and pleural ganglia, as does the esophagus, but it goes below the buccal commissure, whereas the esophagus passes above it. This muscle spreads out fan-shaped at its anterior end, where it is attached chiefly to the cartilaginous base of the buccal mass. It divides into two distinct parts before reaching the nerve ring or each branch may be further divided. In Cerion uva there are 4 branches on the left and 2 on the right, while in Cerion incanum and Cerion casablancee no definite divisions are found. In Cerion viaregis these divisions are very numerous and in Cerion crassilabris 3 occur on the left side and 2 on the right.

The salivary ducts are very short and lead from a distinctly paired gland. This gland covers the esophagus, to which it is firmly attached for a distance of $6 \mathrm{~mm}$. At the posterior end of the salivary gland the esophagus is firmly attached to the buccal retractor muscle. The same relationship holds good in practically all the species examined.

The esophagus becomes perceptibly constricted as it follows the several muscles backward into the visceral mass behind the salivary glands. The anterior end of the stomach lies immediately behind the pericardium and kidney. The walls of the stomach are remarkable for their great length, narrowness, and thinness. The posterior end of the stomach lies high up in the whorls of the visceral mass and it is at this point that the two lobes of the liver discharge their secretion by distinct ducts. The posterior lobe of the liver occupies the upper whorls of the shell, while the anterior lobe is distributed among the various organs below this. Both lobes are brownish-gray in color. The intestine forms a tube slightly larger than the esophagus and passes forward from the posterior end of the stomach. It makes the characteristic visceral loop back of the pulmonary cavity. In some of the species it is embedded in the albumen gland of the genital system, but in Cerion crassilabris and Cerion viaregis the albumen gland is free and the visceral lobe is rather imperfect. The intestine passes forward on the right side of the pulmonary cavity, to the dorsal wall of which it is firmly attached. In this region it is slightly larger than on the rest of its course and in Cerion incanum and Cerion crassilabris it appears to contain some glandular tissues in this region. The entire length of the alimentary tract amounts to about $85 \mathrm{~mm}$. in Cerion incanum.

The pulmonary cavity occupies more than one whorl of the shell when the animal is expanded. Its dorsal wall is thin, transparent, and unmarked excepting a scarcely perceptible pigmentation along the sides of the pulmonary vein. The pericardium and kidney are situated at the posterior end of the pulmonary cavity. The former is shorter than the kidney, but there is some variation in proportionate lengths. The auricle discharges into the pulmonary vein which passes forward 
to the mantle collar without perceptible branching in any of the species. The kidney lies just to the right of the pericardium and is somewhat pointed anteriorly. It appears as a hollow sack of lightgrajish color, showing the glandular tissue hanging in irregular folds. The kidney is attached to the dorsal wall of the pulmonary cavity and the ureter, joining the latter at the posterior end. The ureter bends to the left as it passes forward, following the ventral side of the intestine to the nephridiopore, which is near the anus.

Considerable difference is shown in the genitalia of the several species examined. Cerion incanum, Cerion casablanca, and Cerion uva in the main agree with the description of Cerion munia chrysalis as described by Pilsbry in the Manual of Conchology. Cerion crassilabris and Cerion viaregis, however, are decidedly different. The terminal element of the system is formed by the atrium. This is broad and capacious in Cerion incanum and Cerion casablancce, and less so in Cerion uva. In Cerion crassilabris and Cerion viaregis it is much larger and much more attenuated than in the rest. In Cerion incanum and Cerion casablancee it is provided with a fleshy protuberance and some longitudinal folds which are evertible in copulation.

The penis is attached to the right side of the atrium and differs considerably in shape and length in the species examined. In Cerion incanum and Cerion casablance it tapers to the upper end. In Cerion uva it is bulbous at the upper end, while in Cerion crassilabris its shape is more or less cylindrical. In Cerion viaregis it is larger at the upper end than in any of the other forms. The retractor muscle is attached to the upper end of the penis sack in every case and is inserted not far back on the floor of the pulmonary carity. In Cerion incanum and Cerion casablancee the vas deferens is attached to the lower end of the penis. Its walls are densely muscular proximally, while distally it develops into a much coiled duct. The lower end has a silky appearance which seems to be due to the circular fibers in its structure. In Cerion uva the insertion of the vas deferens is at the upper end of the penis sack, while in Cerion crassilabris it is at about its center. These two species have the duct doubled back and attached to the ragina for its full length by muscle fibers. This is particularly so at the junction of the vagina with the atrium. In Cerion viaregio the vas deferens is attached to the upper end of the penis sack, but in a different manner than in the other forms examined. The attachment to the vagina in this form is less firm than in the others. (The figures of the gecit,alia in our plates show the organs disentangled in order to bring out details.) In Cerion incanum, Cerion casablancoe, and Cerion crassilabris the vas deferens is attached high up on the genital system, far above the attachment of the spermatic duct. In Cerion uva it is attached about halfway as high up on the vagina as it is in the species just mentioned, while in Cerion viaregis it enters the ragina far below the attachment 
of the spermatic duct. The vagina in all the species examined is attached to the leit side of the atrium and is not clearly differentiated from the oviduct abore; it is without fo'ds. In Cerion incanum, Cerism casablanse, Cerion ura, and Cerion crassilabris the spermatic duc: enters the raving slightl behind the atrium. In all of these it is largest at the lower end. This is $\mathrm{L}:$ pronounced in Cerion incanum and least $\leqslant 0$ in Cerion casablaricc. In Cerion viaregis it is attached about halfway between the atrium and albumen gland. In Cerion incanum, Cerion casablance. and Cerion una the spermatic duct is long $E$ rd slender and prorided with a long flagellum near its upper fourth. This flagellum 'dinerticulum of Pilsbry) is ereferion incanum and is shortest in Cerion uxa. It is variously disposed swerg the riscera, but is not folded in any of the species examined. In Cerion incanum it follo -5 the periphery of the whorls and its upper end is near the apex. This organ is entirely abset in Cerion crassilabris and Cerion viaregis. It has also been recorded absent in Cerion yumaense Pilsbry and Vanitta. The spermatic duct in all the species examined follo the risis and riduct, is which it is adherent. The spermatheca may be globular or slightly elongated. In Cerion viaregis it $:$ entirely absent. In this case it may be possble itsi what we hare called the spermatie duct may in reality be the flagellum, the last remairitg element of the sermatheca.

The vagina is attached at the lower end to the right cephalic retractor muscle by a heary band of muscle, which is in two parts in Cerion incarum. The right ocular retractor is attached to the ragina at the same point in all but Cerion crassilabris, in which it connects directly with the cephalic retractor. The oriduct follows the columella of the sell and is thin and membranous on the periphery, and someriht folded. The glandular tiscue occupies a band along its inner margin. It crntair : gelatinous matter which swells and bursts the walls when the organ is placed in contact with water. These ot ser aticis do not obtain in Cerion viaregis. In it: $:$ form there is no apparent diffenentiation in structure between the ragina and criduct. The former appears $\because$ continue unmodified to the albumen glesd. The albumen $g$ is situated at the upper end of the oriduct and has the loop of the irtestine coiled abot $t$ it in all except Cerion crassilabris and Cerion viaregis, ir which it is free. The hermaphroditic duct enters the concave margin of the albumen gland $\approx:$ a sligh + Iy conroluted tube and follcrs: the columella of the shell upward to the hermaphroditic gland. In Cerion incanum, Cerisn casablance, Cerion usa, and Cerion crassilabris this duct is colored dark brown or black in its lowest portion. In Cerion crassizabris it is swollen in the lower part. In Cerions viaregis it is a simple straight duct without conrolutions or pigment. The hermaphroditic gland :s embedded in the tiszice of the upper lobe of the liver, to which it is firmly attached. The color of the two is the same and 
they are often difficult to distinguish. The organ is composed of a large number of minute tubules.

There are four main muscle bands which follow the columella of the shell far up the interior to their place of attachment; these, in the order of their attachment, are: the columellar, right cephalic, buccal, and left cephalic muscles. The first spreads out in the tissue of the foot back of the opening to the buccal cavity. The right cephalic in Cerion incanum is attached to the shell with the columellar muscle. At its anterior end it is attached to the vagina and the right side of the head. The right tentacular retractor is attached to it. The right ocular retractor is also attached to it in Cerion crassilabris. The buccal retractor and left cephalic retractor are attached to the shell together and are placed slightly above the other two. The former has been described, the latter is attached to the left side of the head and the left tentacular and ocular retractors are attached to it. One right cephalic muscle in a well-expanded example of Cerion incanum was $12 \mathrm{~mm}$. long.

While there is a general similarity in the disposition of nerve structures in all of the species examined, there is also some variation. The length of the cerebral commissure is not constant. In Cerion crassilabris and Cerion viaregis, the cerebral, pleural, and pleuro-pedal commissures are perfectly distinct, while in the other species the first two elements are superficially attached through a portion of their length, the length of the commissure being so short that the ganglia are adjacent. The esophageal ring is large and does not bind the esophagus to the body floor, as in some mollusks. In a specimen of Cerion viaregis in which partial contraction had taken place, the buccal mass had been retracted through the ring. The structure of these elements, especially the cerebro-buccal commissure, would indicate that this was the normal state. The cerebral ganglia in normally expanded animals lie on top of the posterior portion of the buccal mass. The heavy connecting commissure passes over the salivary ducts and the esophagus. This is comparatively long in Cerion uva (Iinnæus) and practically absent in Cerion crassilabris. The shape and size of the two side cerebral ganglia is the same.

There is a forward extension of the optic ganglion (best seen in side views), from which the optic nerve arises. Two nerves arise from the outer side of each ganglion. The upper one is the tentacular, while the lower one passes to the lip of the corresponding side. Both of these, as well as the optic nerve, terminate distally in enlargements which suggest ganglionic development. The cerebro-buccal commissure arises on the lower, inner, and anterior side of the cerebral ganglion. This is not free throughout its length, but becomes firmly bound to the buccal mass before it reaches the buccal ganglion. This condition seems to permit the buccal mass to retract through the nerve ring. 
Each buccal ganglion is situated adjacent to the attachment of the esophagus and the commissure passes beneath this over the buccal retractor muscle. The cerebro-pleural and pedal commissures arise on the ventral side of the cerebral ganglia. In some of the species they are united for a portion of their length, but in Cerion crassilabris and Cerion viaregis they are free throughout. The cerebral pleural commissure lies posterior to the pedal commissure. In some of the species nerves are found arising from the cerebral pleural commissures which pass to the right and left cephalic retractor muscles.

The pleural elements are asymmetrical, a greater development being present on the left side. There are five ganglia in all, two on the right side and three on the left. From the upper two, pleural pedal commissures pass forward to the pedal ganglia. In Cerion incanum, Cerion uva, and Cerion casablancee these nerves are so short as to be scarcely discernible. The two true pleural ganglia are the largest of the series, the left being slightly the larger of the two. From the right one a large nerve arises and passes to the mantle collar, while two large nerves pass from the left to the floor of the pulmonary cavity. Between the left pleural and the upper pleural there is an extra ganglion which may correspond to the abdominal ganglion of certain other mollusks. At all events, it gives rise to a large nerve which passes to the viscera. The two pedal ganglia lie just in front of the pleural ganglia and are practically of equal size and shape. They join indirectly without a commissure. Numerous nerves pass from these to the tissues of the foot, especially in the anterior region.

$A$ very distinct blood-vessel passes between the pleural and pedal elements, which connects the base of the buccal mass with the wall of the mantle covering the visceral mass. It then passes backward beneath the pulmonary cavity, being free throughout most of its length.

The great diversity in the anatomical structure of the five species of Cerions examined might tempt one to generalization, but I believe that it is well to postpone this until a much larger series of species has been examined. It will then be easier to judge what values are to be assigned to the various structural differentiations observed in Cerions.

\section{THE COLONIES INTRODUCED INTO THE FLORIDA KEYS.}

We will take these up under the various species involved and discuss the colonies under each in serial rotation from north to south, $i . e$, from the Biscayne Bay region to the Dry Tortugas.

\section{Cerion viaregis Bartsch.}

Of this species, 100 specimens have been taken at random from a lot of Bahama material collected along King's Road, Bastian Point, Andros. These yield the measurements given in table 1 ; figures of them 
are given on plates $7,8,9$. These specimens are entered as Cat. No. 234722 , U. S. N. M., and No. 21 is selected to serve as the type of this species.

TABLE No. 1.-Check series of Cerion viaregis.

\begin{tabular}{|c|c|c|c|c|c|c|c|c|c|c|c|}
\hline \multirow{2}{*}{$\begin{array}{l}\text { Serial } \\
\text { No. }\end{array}$} & \multirow{2}{*}{$\begin{array}{l}\text { No. of } \\
\text { whorls. }\end{array}$} & \multicolumn{2}{|c|}{$\begin{array}{l}\text { Measurements } \\
\text { of shells. }\end{array}$} & \multirow{2}{*}{$\begin{array}{c}\text { Serial } \\
\text { No. }\end{array}$} & \multirow{2}{*}{$\begin{array}{l}\text { No. of } \\
\text { whorls. }\end{array}$} & \multicolumn{2}{|c|}{$\begin{array}{l}\text { Measurements } \\
\text { of shells. }\end{array}$} & \multirow{2}{*}{$\begin{array}{c}\text { Serial } \\
\text { No. }\end{array}$} & \multirow{2}{*}{$\begin{array}{l}\text { No. of } \\
\text { whorls. }\end{array}$} & \multicolumn{2}{|c|}{$\begin{array}{l}\text { Measurements } \\
\text { of shells. }\end{array}$} \\
\hline & & Alt. & Diam. & & & Alt. & Diam. & & & Alt. & Diam. \\
\hline & & $m m$ & $m m$ & & & $m m$ & $m m$ & & & $m m$. & $m m$ \\
\hline 1 & 10.5 & 28.0 & 12.7 & 36 & 9.6 & 23.0 & 11.0 & 71 & 9.8 & 20.0 & 11.1 \\
\hline 2 & 10.3 & 25.0 & 11.5 & 37 & 10.0 & 22.1 & 10.0 & 72 & 10.0 & 23.0 & 11.9 \\
\hline 3 & 10.0 & 23.0 & 12.1 & 38 & 9.8 & 22.1 & 11.0 & 73 & 9.9 & 24.0 & 11.0 \\
\hline 4 & 9.7 & 20.0 & 9.1 & 39 & 10.0 & 22.4 & 11.5 & 74 & 11.0 & 22.9 & 10.0 \\
\hline 5 & 9.9 & 24.5 & 11.0 & 40 & 10.7 & 23.8 & 11.0 & 75 & 10.0 & 21.5 & 11.0 \\
\hline 6 & 9.1 & 19.4 & 9.0 & 41 & 9.9 & 21.8 & 11.5 & 76 & 10.5 & 21.5 & 11.0 \\
\hline 7 & 10.8 & 24.3 & 11.3 & 42 & 9.9 & 21.7 & 11.0 & 77 & 9.9 & 21.0 & 10.4 \\
\hline 8 & 10.8 & 24.4 & 12.0 & 43 & 9.9 & 23.6 & 11.0 & 78 & 11.0 & 23.6 & 11.0 \\
\hline 9 & 11.0 & 27.0 & 12.0 & 44 & 9.8 & 22.5 & 11.0 & 79 & 10.0 & 21.0 & 11.4 \\
\hline 10 & 10.4 & 24.5 & 13.5 & 45 & 10.3 & 24.5 & 11.5 & 80 & 10.0 & 22.0 & 11.0 \\
\hline 11 & 9.3 & 20.5 & 11.0 & 46 & 10.5 & 22.8 & 11.4 & 81 & 10.0 & 22.7 & 11.4 \\
\hline 12 & 10.5 & 23.8 & 12.0 & 47 & 10.3 & 22.7 & 11.1 & 82 & 9.8 & 21.3 & 10.5 \\
\hline 13 & 10.6 & 22.7 & 11.0 & 48 & 10.5 & 24.0 & 11.8 & 83 & 9.7 & 21.5 & 11.0 \\
\hline 14 & 10.0 & 23.0 & 11.0 & 49 & 9.9 & 19.0 & 11.0 & 84 & 9.9 & 21.8 & 11.0 \\
\hline 15 & 10.1 & 24.4 & 12.0 & 50 & 10.6 & 23.9 & 11.0 & 85 & 9.6 & 21.0 & 11.0 \\
\hline 16 & 9.9 & 22.0 & 12.0 & 51 & 9.6 & 22.0 & 11.8 & 86 & 10.5 & 22.2 & 12.0 \\
\hline 17 & 10.4 & 24.0 & 11.0 & 52 & 10.0 & 22.5 & 10.5 & 87 & 9.8 & 21.1 & 10.9 \\
\hline 18 & 10.0 & 22.5 & 10.5 & 53 & 9.0 & 24.0 & 10.5 & 88 & 9.6 & 20.0 & 11.0 \\
\hline 19 & 11.0 & 25.5 & 11.2 & 54 & 10.2 & 23.0 & 11.5 & 89 & 9.6 & 20.5 & 9.4 \\
\hline 20 & 9.0 & 23.0 & 12.0 & 55 & 10.5 & 22.8 & 12.0 & 90 & 9.8 & 21.5 & 10.5 \\
\hline 21 & 10.0 & 22.9 & 11.0 & 56 & 10.0 & 20.3 & 10.5 & 91 & 10.3 & 23.2 & 10.5 \\
\hline 22 & 10.0 & 22.8 & 10.5 & 57 & 9.3 & 22.0 & 11.0 & 92 & 10.2 & 25.0 & 11.5 \\
\hline 23 & 10.4 & 24.0 & 11.0 & 58 & 10.2 & 24.1 & 11.0 & 93 & 10.4 & 23.2 & 11.6 \\
\hline 24 & 10.1 & 23.9 & 12.0 & 59 & 9.7 & 20.8 & 10.8 & 94 & 9.8 & 21.8 & 10.9 \\
\hline 25 & 10.4 & 24.5 & 12.2 & 60 & 10.0 & 21.5 & 11.5 & 95 & 10.1 & 21.1 & 10.2 \\
\hline 26 & 10.4 & 24.5 & 12.0 & 61 & 10.0 & 21.5 & 11.2 & 96 & 10.6 & 23.0 & 11.1 \\
\hline 27 & 9.8 & 22.5 & 11.4 & 62 & 9.6 & 21.5 & 11.4 & 97 & 10.8 & 23.6 & 11.1 \\
\hline 28 & 9.9 & 24.0 & 11.5 & 63 & 9.7 & 21.4 & 10.9 & 98 & 10.2 & 20.0 & 10.0 \\
\hline 29 & 11.0 & 21.6 & 9.5 & 64 & 9.8 & 21.5 & 11.5 & 99 & 10.4 & 21.5 & 10.5 \\
\hline 30 & 9.9 & 23.5 & 11.9 & 65 & 10.0 & 22.8 & 9.5 & 100 & 10.3 & 21.3 & 10.3 \\
\hline 31 & 10.6 & 23.4 & 12.4 & 66 & 10.0 & 22.0 & 11.5 & & & & \\
\hline 32 & 10.6 & 24.0 & 11.5 & 67 & 10.6 & 22.0 & 11.5 & Average. & 10.08 & 22.56 & 11.13 \\
\hline 33 & 8.8 & 19.0 & 10.5 & 68 & 9.6 & 21.5 & 12.0 & Greatest. & 11.0 & 27.0 & 12.7 \\
\hline 34 & 9.9 & 21.0 & 12.0 & 69 & 9.5 & 21.5 & 10.5 & Least... & 9.1 & 19.0 & 9.0 \\
\hline 35 & 10.6 & 23.5 & 11.0 & 70 & 10.0 & 23.0 & 11.5 & & & & \\
\hline
\end{tabular}

The Colony on the Second Ragged Key North of Sands Key.

The northernmost colony is situated on the Second Ragged Key north of Sands Key. Here 500 of Cerion viaregis were planted on a low sandy ridge on the southeastern end of this small island in 1912. The vegetation at this point is quite variable. Hymenocallis (commonly called $A$ marillis in this general region) forms the most succulent portion of the plant element, while Sporobulus virginicus and Gayoides imberbe and a few scattered, shrubby plants furnish a scant covering for quite a stretch of beach sand. The outer and inner edge of the dune is fringed with a mangrove thicket. There is likewise a lot of piled-up sea drift in places. 
Our visit in 1913 showed that our Cerions had spread over all the above-described territory.

On April 21, 1914, we again visited this plantation and found 55 young of the first generation of Florida-grown individuals, 3 of which had attained adult size; these we figured in the 1915 report, plate III, figures 1 to 3 , bottom row. They are discussed in the text. We transplanted these to a grassy spot about 62 feet northeast of the old plantation on the same key.

From this colony 76 adult shells of the first generation of Floridagrown specimens were gathered in June 1915, measured, and photographed. The measurements are given in table 2 and the photographs on plates 10 and 11 .

TABLE No. 2,-Measurements of the first generation of Florida-grown Cerion viaregis from the second key north of Sands Key.

\begin{tabular}{|c|c|c|c|c|c|c|c|c|c|c|c|}
\hline \multirow{2}{*}{$\begin{array}{l}\text { Serial } \\
\text { No. }\end{array}$} & \multirow{2}{*}{$\begin{array}{l}\text { No. of } \\
\text { whorls. }\end{array}$} & \multicolumn{2}{|c|}{$\begin{array}{l}\text { Measurements } \\
\text { of shells. }\end{array}$} & \multirow{2}{*}{$\begin{array}{c}\text { Serial } \\
\text { No. }\end{array}$} & \multirow{2}{*}{$\begin{array}{l}\text { No. of } \\
\text { whorls. }\end{array}$} & \multicolumn{2}{|c|}{$\begin{array}{l}\text { Measurements } \\
\text { of shells. }\end{array}$} & \multirow{2}{*}{$\begin{array}{l}\text { Serial } \\
\text { No. }\end{array}$} & \multirow{2}{*}{$\begin{array}{l}\text { No. of } \\
\text { whorls. }\end{array}$} & \multicolumn{2}{|c|}{$\begin{array}{l}\text { Measurement } \\
\text { of shells. }\end{array}$} \\
\hline & & Alt. & Diam. & & & Alt. & Diam. & & & Alt. & Diam \\
\hline & & $m m$. & $m m$. & 28 & 100 & $m m$. & $m m$ & 55 & 05 & $m m$. & $m m$. \\
\hline $\begin{array}{l}1 \\
2\end{array}$ & $\begin{array}{l}10.0 \\
10.5\end{array}$ & $\begin{array}{l}21.9 \\
24.9\end{array}$ & $\begin{array}{l}10.6 \\
11.1\end{array}$ & $\begin{array}{l}28 \\
29\end{array}$ & $\begin{array}{r}10.0 \\
9.5\end{array}$ & $\begin{array}{l}20.9 \\
21.7\end{array}$ & $\begin{array}{l}10.5 \\
10.3\end{array}$ & $\begin{array}{l}55 \\
56\end{array}$ & $\begin{array}{r}9.5 \\
11.0\end{array}$ & $\begin{array}{l}21.0 \\
24.9\end{array}$ & $\begin{array}{l}10.2 \\
10.4\end{array}$ \\
\hline 3 & 10.3 & 22.5 & 11.1 & 30 & 10.1 & 25.2 & 10.7 & 57 & 10.7 & 25.8 & 10.6 \\
\hline 4 & 10.0 & 22.7 & 11.0 & 31 & 10.0 & 23.0 & 10.7 & 58 & 9.7 & 23.8 & 11.0 \\
\hline 5 & 9.9 & 22.0 & 9.5 & 32 & 9.8 & 22.9 & 10.0 & 59 & 10.6 & 24.9 & 10.7 \\
\hline 6 & 10.0 & 22.8 & 10.8 & 33 & 10.5 & 23.1 & 10.0 & 60 & 9.7 & 22.0 & 10.6 \\
\hline 7 & 10.5 & 23.2 & 10.8 & 34 & 10.4 & 23.8 & 10.2 & 61 & 9.7 & 22.5 & 10.4 \\
\hline 8 & 10.5 & 24.0 & 11.0 & 35 & 10.4 & 23.7 & 10.0 & 62 & 9.6 & 22.0 & 10.0 \\
\hline 9 & 10.0 & 23.7 & 9.9 & 36 & 10.0 & 23.4 & 10.2 & 63 & 10.6 & 24.0 & 11.2 \\
\hline 10 & 10.0 & 21.5 & 10.0 & 37 & 9.9 & 22.3 & 10.3 & 64 & 9.6 & 22.5 & 11.2 \\
\hline 11 & 10.1 & 23.3 & 10.0 & 38 & 10.4 & 23.0 & 10.0 & 65 & 9.4 & 20.0 & 10.7 \\
\hline 12 & 10.1 & 23.8 & 10.2 & 39 & 10.4 & 24.4 & 10.5 & 66 & 10.0 & 23,5 & 10.6 \\
\hline 13 & 10.5 & 24.5 & 10.0 & 40 & 10.5 & 24.0 & 10.0 & 67 & 10.2 & 21.8 & 10.3 \\
\hline 14 & 10.5 & 23.8 & 9.5 & 41 & 10.4 & 22.8 & 10.2 & 68 & 10.1 & 22.7 & 10.0 \\
\hline 15 & 8.9 & 19.2 & 9.9 & 42 & 10.3 & 23.5 & 10.5 & 69 & 10.1 & 22.9 & 10.0 \\
\hline 16 & 10.0 & 24.9 & 10.3 & 43 & 10.3 & 23.3 & 10.3 & 70 & 9.4 & 21.8 & 10.4 \\
\hline 17 & 9.8 & 21.5 & 10.0 & 44 & 9.5 & 21.0 & 10.0 & 71 & 10.0 & 23.9 & 11.2 \\
\hline 18 & 9.8 & 21.6 & 10.0 & 45 & 9.7 & 22.0 & 10.2 & 72 & 10.6 & 24.0 & 10.0 \\
\hline 19 & 10.5 & 25.0 & 10.1 & 46 & 10.3 & 22.2 & 10.6 & 73 & 10.0 & 22.5 & 10.0 \\
\hline 20 & 9.6 & 22.3 & 10.1 & 47 & 9.1 & 20.0 & 10.5 & 74 & 9.5 & 21.5 & 10.0 \\
\hline 21 & 9.6 & 21.9 & 10.0 & 48 & 10.3 & 22.8 & 10.5 & 75 & 9.8 & 19.5 & 11.0 \\
\hline 22 & 10.1 & 22.5 & 10.0 & 49 & 10.0 & 23.1 & 11.4 & 76 & 9.7 & 22.6 & 11.3 \\
\hline 23 & 10.0 & 23.0 & 10.8 & 50 & 9.9 & 22.5 & 10.0 & & & & \\
\hline 24 & 9.7 & 21.2 & 10.3 & 51 & 10.3 & 23.8 & 10.6 & Average. & 10.03 & 22.82 & 10.4 \\
\hline 25 & 10.1 & 24.0 & 10.5 & 52 & 10.2 & 23.8 & 10.5 & Greatest. & 11.0 & 25.8 & 11.4 \\
\hline 26 & 9.6 & 21.5 & 10.1 & 53 & 10.1 & 22.5 & 11.0 & Least... & 8.9 & 19.2 & 9.5 \\
\hline 27 & 9.9 & 23.9 & 10.7 & 54 & 10.1 & 22.7 & 10.9 & & & & \\
\hline
\end{tabular}

On May 16, 1916, the old planting was doing well. Old and young were up in the vegetation. The old colony occupied almost the same extent of territory that it held the year before. The two other plantings were all doing well.

The planting was not visited in 1917 or 1918. In January 1919, we again examined it and found the first planting flourishing. In the new plantings, however, we did not find the mollusks abundant, 
but we secured 8 individuals belonging to the second generation of Florida-grown specimens, of which table 3 gives measurements. They are figured on plate 24 , middle set of figures.

TABLE No. 3.-Measurements of the second generation of Florida-grown Cerion viaregis from the second key north of Sands Key.

\begin{tabular}{|c|c|c|c|c|c|c|c|c|c|c|c|}
\hline \multirow{2}{*}{$\begin{array}{l}\text { Serial } \\
\text { No. }\end{array}$} & \multirow{2}{*}{$\begin{array}{l}\text { No. of } \\
\text { whorls. }\end{array}$} & \multicolumn{2}{|c|}{$\begin{array}{l}\text { Measurements } \\
\text { of shells. }\end{array}$} & \multirow{2}{*}{$\begin{array}{l}\text { Serial } \\
\text { No. }\end{array}$} & \multirow{2}{*}{$\begin{array}{l}\text { No. of } \\
\text { whorls. }\end{array}$} & \multicolumn{2}{|c|}{$\begin{array}{l}\text { Measurements } \\
\text { of shells. }\end{array}$} & \multirow{2}{*}{ Summary. } & \multirow{2}{*}{$\begin{array}{l}\text { No. of } \\
\text { whorls. }\end{array}$} & \multicolumn{2}{|c|}{$\begin{array}{l}\text { Measurements } \\
\text { of shells. }\end{array}$} \\
\hline & & Alt. & Diam. & & & Alt. & Diam. & & & Alt. & Diam. \\
\hline 1 & 10.0 & $\begin{array}{l}m m . \\
22.6\end{array}$ & $\begin{array}{l}m m . \\
11.2\end{array}$ & 5 & 10.1 & $\begin{array}{l}m m . \\
23.4\end{array}$ & $m m$. & & 10.21 & $\begin{array}{l}m m . \\
22.95\end{array}$ & $\begin{array}{l}m m . \\
10.87\end{array}$ \\
\hline 2 & 10.5 & 23.0 & 10.2 & 6 & 10.0 & $\begin{array}{l}21.8 \\
21.8\end{array}$ & 11.0 & Greatest. & 11.1 & 24.2 & 11.3 \\
\hline 3 & 10.3 & 24.2 & 11.0 & 7 & 9.6 & 21.0 & 10.7 & Least... & 9.6 & 21.0 & 10.2 \\
\hline 4 & 11.1 & 26.4 & 11.3 & 8 & 10.1 & 21.2 & 10.5 & & & & \\
\hline
\end{tabular}

The Colony on Tea Table Key.

On June 1, 1912, we planted 500 specimens of Cerion viaregis on Tea Table Key. These were scattered about the ruins of an old house on the north side of the island. The ground seemed ideal, coarse calcareous beach sand supporting a scanty scattered herbaceous vegetation. When we visited the place on April 27, 1913, where the planting had been made, we found it covered with a rank growth of a malvaceous plant which seemed to be unsuited to the Cerions, for they had all left it and wandered inland, some as much as 100 feet. Most of them expired on this journey, for of the 75 recovered, only 3 were alive; these we placed in a clump of Hymenocallis, about 200 feet northwest of a cordia tree, which is about 100 feet west of the old building where the first planting was made. The aspect of the place where the original planting was made seemed very favorable for Cerions last year, for the malvaceous plants had died and shed their foliage after fruiting.

Our visit on April 22, 1914, showed no living Cerion. At that time the island was completely overrun with crabs, the entire land mass being simply riddled with their burrows. It is quite possible that the small hermit crabs which were also swarming on this key at the time may have carried off the dead shells.

It seems safe to assume that the colony on this key is extinct, as our visits in 1915, 1916, 1917, and 1919 showed no trace of Cerions, and in January 1919 the greater part of the key was covered by a tomato plantation.

\section{The Colony on Duck Kex.}

On June 2, 1912, a planting of 500 specimens of Cerion viaregis was made on the south side of Duck Key. At that time the key was covered by a scattered growth of Uniola paniculata. On our visit on April 28, 1913, this colony was doing well. 
All visits during subsequent years have shown that this little island has become so completely swamped with grass that it has been impossible to determine whether Cerions have survived in large numbers or whether they are multiplying. Occasionally a young tip has been seen, and in 1916 we found one young locally grown specimen. It has therefore been impossible to gain material representing the first and second generations. Not until some time in the future, when drought or some other condition will have overcome the rank grass, will it be possible to determine the true status of this colony.

The Colony on Newfound Harbor Key.

On June 3, 1912, in a low grassy plain in the middle of Newfound Harbor Key, 500 specimens of Cerion viaregis were planted. When visited on April 28, 1913, the place had become densely matted with a luxuriant growth of grass, Sporobolus virginicus, and was quite moist; apparently the low depression in the middle had been flooded by some storm. Fearing that a more serious inundation might kill the members of this colony, a new place was selected for the 145 specimens recovered, of which 14 were dead. The 131 living specimens were carried inland to the sandy ridge, where they were placed between the coconut trees. The tree near which the planting was made was marked by a double cross cut in its trunk.

On April 23, 1914, we again visited Newfound Harbor Key and found that the place of the second planting was swamped with a dense growth of a malvaceous plant, overgrown with a leguminous climber, indicating that a very poor choice of location had been made for this planting last year.

In 1915 this colony was not examined.

On May 22, 1916, the ground where the second planting was made had been completely burned over; only a single specimen of the originally planted material and one locally grown individual were found; but in the low flat where the first planting was made, we found 51 individuals which represent the first generation of the Florida-grown specimens and 3 of the original planting. Among these were 4 shells of hybrids between Cerion viaregis and the native Cerion incanum. These were on bushes which carried both introduced and local forms.

It should be stated that at our first planting on this key, in 1912, no native Cerions appeared.

In 1917 and 1918 this colony was not visited, but on January 19, 1919, when we revisited the place, the Cerion colony in the middle of the plain was doing well. Numerous individuals were present everywhere, but most of the individuals were hybrids between Cerion incanum (Binney) and Cerion viaregis. We gathered a goodly quantity of these, which were taken to Washington and placed in a conservatory for continued close observation and possible selective breeding. The 
details presented by this material will be discussed at another place in this report. The second plantation on the ridge seemed to have recovered from the effects of the fire, but only a few specimens of the King's Road type were there, and absolutely no trace of an admixture with Cerion incanum was shown in any of the specimens.

The Colony on Boca Grande Key.

On June 8, 1912, we planted 500 specimens of Cerion viaregis beneath the U. S. Coast Survey beacon on the northwest end of Boca Grande Key. The ground at this place is the usual coarse-grained calcareous sand supporting a rather luxuriant growth of Uniola paniculata. This colony was doing well on May 1, 1913.

TABLE No. 4.-Measurements of the first generation of Florida-grown Cerion viaregis from Boca Grande Key.

\begin{tabular}{|c|c|c|c|c|c|c|c|c|c|c|c|}
\hline \multirow{2}{*}{$\begin{array}{l}\text { Serial } \\
\text { No. }\end{array}$} & \multirow{2}{*}{$\begin{array}{l}\text { No. of } \\
\text { whorls. }\end{array}$} & \multicolumn{2}{|c|}{$\begin{array}{l}\text { Measurements } \\
\text { of shells. }\end{array}$} & \multirow{2}{*}{$\begin{array}{l}\text { Serial } \\
\text { No. }\end{array}$} & \multirow{2}{*}{$\begin{array}{l}\text { No. of } \\
\text { whorls. }\end{array}$} & \multicolumn{2}{|c|}{$\begin{array}{l}\text { Measurements } \\
\text { of shells. }\end{array}$} & \multirow{2}{*}{$\begin{array}{l}\text { Serial } \\
\text { No. }\end{array}$} & \multirow{2}{*}{$\begin{array}{l}\text { No. of } \\
\text { whorls. }\end{array}$} & \multicolumn{2}{|c|}{$\begin{array}{l}\text { Measurements } \\
\text { of shells. }\end{array}$} \\
\hline & & Alt. & Diam. & & & Alt. & Diam. & & & Alt. & Diam. \\
\hline & 10.9 & $\begin{array}{l}m m . \\
24.8\end{array}$ & $\begin{array}{l}m m . \\
11.0\end{array}$ & 38 & 10.3 & $\begin{array}{l}m m . \\
25.3\end{array}$ & $m m$. & 75 & 10.0 & $\begin{array}{l}m m . \\
22.2\end{array}$ & $\begin{array}{l}m m . \\
10.1\end{array}$ \\
\hline $\begin{array}{l}1 \\
2\end{array}$ & $\begin{array}{l}10.9 \\
10.7\end{array}$ & $\begin{array}{l}24.8 \\
24.2\end{array}$ & $\begin{array}{l}11.0 \\
10.9\end{array}$ & $\begin{array}{l}50 \\
39\end{array}$ & 9.8 & 21.9 & 10.1 & 76 & 10.5 & 24.0 & $\begin{array}{l}10.1 \\
11.2\end{array}$ \\
\hline 3 & 10.1 & 23.4 & 10.7 & 40 & 10.9 & 27.1 & 11.2 & 77 & 10.3 & 23.5 & 11.0 \\
\hline 4 & 11.0 & 26.5 & 10.0 & 41 & 10.3 & 21.8 & 10.0 & 78 & 9.9 & 22.6 & 9.0 \\
\hline 5 & 10.2 & 25.5 & 11.2 & 42 & 9.1 & 21.0 & 10.3 & 79 & 9.8 & 23.1 & 10.0 \\
\hline 6 & 10.4 & 25.4 & 11.4 & 43 & 9.7 & 21.7 & 10.0 & 80 & 9.9 & 21.9 & 10.1 \\
\hline 7 & 10.2 & 23.1 & 10.3 & 44 & 11.1 & 25.8 & 9.6 & 81 & 10.2 & 24.2 & 11.0 \\
\hline 8 & 10.3 & 22.6 & 10.5 & 45 & 10.9 & 23.2 & 11.0 & 82 & 10.3 & 21.6 & 10.1 \\
\hline 9 & 10.2 & 24.1 & 10.8 & 46 & 10.7 & 24.9 & 11.4 & 83 & 10.4 & 24.1 & 10.2 \\
\hline 10 & 10.3 & 22.2 & 9.9 & 47 & 10.3 & 23.6 & 10.5 & 84 & 10.4 & 23.7 & 10.0 \\
\hline 11 & 10.4 & 23.5 & 10.4 & 48 & 10.1 & 24.0 & 10.5 & 85 & 10.3 & 23.9 & 10.3 \\
\hline 12 & 10.4 & 24.2 & 11.3 & 49 & 10.9 & 25.8 & 10.2 & 86 & 10.3 & 24.5 & 10.5 \\
\hline 13. & 10.8 & 23.4 & 10.0 & 50 & 10.3 & 23.5 & 11.5 & 87 & 10.9 & 24.2 & 10.5 \\
\hline 14 & 10.2 & 23.7 & 11.0 & 51 & 9.7 & 21.5 & 10.4 & 88 & 10.6 & 23.0 & 10.0 \\
\hline 15 & 10.1 & 22.5 & 11.3 & 52 & 9.9 & 23.0 & 10.7 & 89 & 10.6 & 26.0 & 11.6 \\
\hline 16 & 10.5 & 25.0 & 10.5 & 53 & 10.6 & 24.7 & 10.5 & 90 & 9.9 & 22.0 & 9.9 \\
\hline 17 & 10.1 & 23.4 & 10.2 & 54 & 10.9 & 25.2 & 10.5 & 91 & 10.4 & 24.0 & 11.4 \\
\hline 18 & 10.4 & 22.2 & 10.5 & 55 & 10.3 & 24.0 & 9.8 & 92 & 10.4 & 22.9 & 10.8 \\
\hline 19 & 9.5 & 21.4 & 10.4 & 56 & 10.7 & 24.7 & 9.9 & 93 & 10.3 & 23.5 & 10.2 \\
\hline 20 & 10.7 & 24.8 & 10.0 & 57 & 10.1 & 24.7 & 10. & 94 & 10.3 & 23.0 & 11.1 \\
\hline 21 & 10.0 & 21.6 & 10.2 & 58 & 10.8 & 24.6 & 10.1 & 95 & 11.1 & 23.7 & 11.0 \\
\hline 22 & 9.9 & 22.0 & 10.0 & 59 & 10.2 & 22.7 & 10.6 & 96 & 10.6 & 25.5 & 11.5 \\
\hline 23 & 10.0 & 23.5 & 10.8 & 60 & 10.6 & 26.4 & 11.0 & 97 & 10.2 & 23.0 & 10.6 \\
\hline 24 & 10.6 & 23.7 & 11.0 & 61 & 11.1 & 26.3 & 11.4 & 98 & 10.7 & 25.8 & 11.3 \\
\hline 25 & 9.9 & 21.9 & 9.7 & 62 & 10.4 & 23.7 & $\begin{array}{r}9.6 \\
\end{array}$ & $\begin{array}{l}90 \\
99\end{array}$ & $\begin{array}{l}10.7 \\
10.7\end{array}$ & 24.5 & 10.0 \\
\hline 26 & 10.9 & 26.5 & 10.7 & 63 & 10.9 & 26.2 & 10.6 & 100 & 9.8 & 21.3 & 10.0 \\
\hline 27 & 10.0 & 21.0 & 9.7 & 64 & 10.5 & 23.9 & 10.4 & 101 & 9.8 & 20.9 & 11.0 \\
\hline 28 & 10.1 & 23.5 & 10.9 & 65 & 10.5 & 24.1 & $\begin{array}{r}9.7 \\
9.7\end{array}$ & 102 & 9.8 & 21.0 & 9.9 \\
\hline 29 & 9.8 & 23.0 & 11.0 & 66 & 9.6 & 22.0 & 9.6 & 103 & 10.8 & 23.7 & 10.9 \\
\hline 30 & 10.3 & 22.5 & 10.3 & 67 & 10.6 & 24,7 & 10.4 & 104 & 11.2 & 26.9 & 11.6 \\
\hline 31 & 9.5 & 20.2 & 10.6 & 68 & 10.2 & 25.2 & 10.7 & 105 & 9.7 & 23.0 & 10.4 \\
\hline 32 & 9.6 & 21.7 & 10.2 & 69 & 9.9 & 22.0 & 10.5 & 106 & 10.3 & 21.7 & $\begin{array}{r}9.6 \\
\end{array}$ \\
\hline 33 & 10.5 & 24.5 & 10.0 & 70 & 9.7 & 20.6 & 10.5 & 107 & 10.3 & 21.8 & 9.4 \\
\hline $\begin{array}{l}34 \\
35\end{array}$ & $\begin{array}{r}10.9 \\
9.7\end{array}$ & $\begin{array}{l}26.8 \\
22.8\end{array}$ & $\begin{array}{r}10.1 \\
9.9\end{array}$ & $\begin{array}{l}71 \\
72\end{array}$ & 10.5 & 25.7 & 10.7 & & & & \\
\hline $\begin{array}{l}30 \\
36\end{array}$ & $\begin{array}{l}9.7 \\
9.9\end{array}$ & $\begin{array}{l}22.8 \\
23.3\end{array}$ & $\begin{array}{r}9.9 \\
10.6\end{array}$ & 72 & $\begin{array}{r}9.9 \\
9\end{array}$ & 21.0 & 9.7 & Averag & 10.31 & 23.57 & 10.46 \\
\hline 37 & 10.3 & 22.4 & 10.0 & 74 & $\begin{array}{l}10.2 \\
10.5\end{array}$ & 22.7 & 9.9 & Greate & 11.2 & 27.1 & 11.6 \\
\hline & & & & & & 25.1 & 10.0 & Least. . & 9.1 & 20.2 & 9.0 \\
\hline
\end{tabular}


On April 29, 1914, it was discovered that the grass had been burned about the beacon and that most of our specimens had been roasted. Quite a number of young, however, were present in the tufts of grass not consumed by fire, and 3 adults and 1 nearly grown of the first Florida-grown generation were found. These are illustrated by the last four figures of the bottom row on plate 3 of the 1915 report.

On June 25, 1915, we again visited Boca Grande Key and collected 119 specimens of the first generation of Florida-grown Cerions; 107 of the adult specimens and 9 of the young, after being marked, measured, and photographed, were replanted on this key about 300 feet south of the beacon, a little nearer the bushes than the shore. A Tournefortia bush standing on the edge of the shore marks the intersecting line opposite which the planting was made. The measurements of these appear in table 4 , and for the figures see plates $12,13,14$.

On June 4, 1916, when we again visited Boca Grande, the beach had been burned over and our second planting, consisting of the first generation of Florida-grown individuals, seemed completely destroyed. In the original planting, however, a few shells were seen on the grass (Uniola paniculata) about the beacon and many more were observed in a little meadow of Sporobolus virginicus, which is separated from the outer beach by a fringe of low bushes. It is possible that this remnant of the colony may rehabilitate this planting.

On July 18, 1917, on revisiting Boca Grande, the colony in the little meadow immediately inside of the fringe of bay cedars near the beacon appeared to be doing well, but no shells were found in the location of the second planting.

On January 6, 1919, we reexamined the planting on Boca Grande and found a few mollusks about the beacon and a goodly number in the little meadow within the fringe of bay cedars, where they had spread for fully 100 feet. No trace of the planting of the first generation of Florida-grown individuals had appeared, and since it is impossible to tell whether the specimens about the beacon belong to the first or second generation, no attempt will be made to utilize them in our discussion. Our experiments for the time being, therefore, have ceased so far as this colony is concerned, and the only further interest that they present will be to see what changes, if any, may occur.

The Colony on Garden Key, Tortugas.

On June 8, 1912, a planting of 138 specimens of Cerion viaregis was made back of a small house on the northeast side of the fort on Garden Key. This planting was visited on May 2, 1913. At this time the place, which is a beach of coarse calcareous sand, was occupied by a sparse growth of Sporobolus virginicus and Uniola paniculata and a rank growth of the goatfoot morning-glory, Ipomoea pes-caprae. I cleared a space of 10 by 20 feet by the use of a pocket knife and recov- 
ered 60 of the planted mollusks. I was told that some visitor had discovered this colony and collected some of the specimens, promising to replace them, but it is not absolutely known whether this had been done. A single young specimen was also discovered at this time, which showed that they were breeding. The place being deemed unsuitable for the colony, the 62 specimens were transplanted to the inside of the fort near the center, where conditions appeared to be much more favorable than in the place first selected. As the fort was about to be abandoned, little fear of interference with this colony was expected.

The Garden Key plantings were examined on April 27, 1914, when it was discovered that the second planting inside of the fort had been completely burned over; 28 dead shells were found, but the rest had disappeared. A visit to the original planting showed 6 living specimens of the original planting, but no young. The place was less overgrown this year than the last. Apparently the cleaning up to which I subjected it then had decreased the morning-glory growth and this gave the Cerions a better chance. We left the 6 specimens in a tuft of grass in this place.

In 1915 no specimens were found in this planting, and in 1916 only a single individual. In neither of these years was there a single trace of Cerions seen on the inside of the fort.

In 1917 and 1918 this planting was not visited, but on January 16, 1919, a careful search was made both within and without the fort, but not a trace of Cerions was discovered, so it is to be feared that this colony has disappeared.

The Colonies on Loggerhead Key, Tortugas.

On this key 10 plantings of Cerion viaregis have been made. They bear the letters $\mathrm{E}, \mathrm{F}, \mathrm{G}, \mathrm{H}, \mathrm{I}, \mathrm{K}, \mathrm{M}, \mathrm{P}, \mathrm{Q}$, and $\mathrm{R}$, and were established in the order listed. We shall discuss them now in this sequence.

The Loggerhead Key Colony E.

On June 8, 1912, in a sandy plain covered by a mixed stand of Uniola paniculata and Sporobolus virginicus, 500 specimens of Cerion viaregis were planted near the south end of the island. The place was marked by a stake.

In May 1913 a large number of young were observed, 55 of which were gathered in 20 minutes in a space of 3 square yards. The young were all about the base of tussocks of grass, some on and some under the surface of the ground.

In April 1914 we gathered 300 young specimens (some of which were figured in the 1915 report, upper figure of plate 5) and 3 full-grown and 3 nearly full-grown individuals (see top row of plate 3 of 1915 report). The young were planted in a small meadow to the northeast of the one in which the present colony is planted. They were marked with a tag 
affixed to a stake bearing the legend "Cerions Z." These represent the initital planting of Colony G. The variations presented by the adult specimens are discussed in the 1915 report.

On June 27, 1915, we found that this colony had spread materially and that many of the snails had taken to the bay cedars bordering the little meadow. Of the first generation of Florida-grown specimens 646 were gathered, 250 of which were photographed and measured. For measurements see table 5, and for the photographs see plates 15-21. These were marked and deposited in the north end of the meadow and the place marked by a stake and a tag bearing the legend: "Cerions, 1915, K." These represent the initital planting of Colony K.

TABLE No. 5.-First generation of Florida-grown Cerion viaregis from Colony $E$.

\begin{tabular}{|c|c|c|c|c|c|c|c|c|c|c|c|}
\hline \multirow{2}{*}{$\begin{array}{l}\text { Serial } \\
\text { No. }\end{array}$} & \multirow{2}{*}{$\begin{array}{l}\text { No. of } \\
\text { whorls. }\end{array}$} & \multicolumn{2}{|c|}{$\begin{array}{l}\text { Measurements } \\
\text { of shells. }\end{array}$} & \multirow{2}{*}{$\begin{array}{l}\text { Serial } \\
\text { No. }\end{array}$} & \multirow{2}{*}{$\begin{array}{l}\text { No. of } \\
\text { whorls. }\end{array}$} & \multicolumn{2}{|c|}{$\begin{array}{l}\text { Measurements } \\
\text { of shells. }\end{array}$} & \multirow{2}{*}{$\begin{array}{l}\text { Serial } \\
\text { No. }\end{array}$} & \multirow{2}{*}{$\begin{array}{l}\text { No. of } \\
\text { whorls. }\end{array}$} & \multicolumn{2}{|c|}{$\begin{array}{l}\text { Measurements } \\
\text { of shells. }\end{array}$} \\
\hline & & Alt. & Diam. & & & Alt. & Diam. & & & Alt. & Diam. \\
\hline 1 & 9.8 & $\begin{array}{l}m m . \\
22.8\end{array}$ & $\begin{array}{c}m m . \\
10.1\end{array}$ & 42 & 10.0 & $\begin{array}{l}m m . \\
24.5\end{array}$ & $\begin{array}{c}m m . \\
10.4\end{array}$ & 83 & 9.7 & $\begin{array}{c}m m . \\
23.6\end{array}$ & $\begin{array}{l}m m . \\
10.3\end{array}$ \\
\hline $\begin{array}{l}1 \\
2\end{array}$ & $\begin{array}{r}9.0 \\
10.2\end{array}$ & 23.2 & 10.6 & 43 & 10.4 & 22.5 & 9.5 & 84 & 10.5 & 24.0 & 10.6 \\
\hline 3 & 10.0 & 21.6 & 10.5 & 44 & 10.6 & 22.5 & 9.1 & 85 & 10.3 & 24.4 & 9.5 \\
\hline 4 & 10.5 & 24.0 & 9.6 & 45 & 10.1 & 22.3 & 10.0 & 86 & 9.5 & 19.8 & 9.3 \\
\hline 5 & 10.9 & 24.1 & 9.8 & 46 & 10.6 & 22.0 & 9.9 & 87 & 9.4 & 20.5 & 10.3 \\
\hline 6 & 10.2 & 23.5 & 10.0 & 47 & 9.5 & 20.6 & 10.2 & 88 & 10.8 & 25.5 & 10.4 \\
\hline 7 & 10.2 & 24.0 & 10.2 & 48 & 10.6 & 26.0 & 9.2 & 89 & 10.4 & 23.0 & 10.5 \\
\hline 8 & 9.6 & 22.7 & 10.3 & 49 & 10.3 & 23.0 & 10.5 & 90 & 9.8 & 20.8 & 9.0 \\
\hline 9 & 10.3 & 23.0 & 10.9 & 50 & 10.3 & 21.8 & 9.6 & 91 & 10.0 & 22.8 & 11.0 \\
\hline 10 & 11.1 & 25.4 & 9.8 & 51 & 10.4 & 23.0 & 9.4 & 92 & 9.8 & 22.7 & 10.1 \\
\hline 11 & 10.2 & 24.6 & 9.1 & 52 & 9.6 & 21.2 & 10.0 & 93 & 10.0 & 20.0 & 10.1 \\
\hline 12 & 9.9 & 22.0 & 9.6 & 53 & 11.2 & 26.7 & 10.8 & 94 & 9.4 & 20.0 & 10.2 \\
\hline 13 & 10.7 & 24.5 & 10.2 & 54 & 9.8 & 23.0 & 10.2 & 95 & 10.3 & 22.5 & 9.7 \\
\hline 14 & 9.7 & 20.9 & 9.5 & 55 & 10.5 & 22.2 & 10.2 & 96 & 9.7 & 21.6 & 9.7 \\
\hline 15 & 10.2 & 23.7 & 10.4 & 56 & 9.7 & 22.4 & 9.7 & 97 & 10.3 & 24.3 & 10.0 \\
\hline 16 & 9.3 & 20.6 & 10.5 & 57 & 10.2 & 21.7 & 10.1 & 98 & 9.9 & 21.5 & 10.2 \\
\hline 17 & 10.2 & 22.7 & 9.8 & 58 & 10.0 & 22.2 & 10.1 & 99 & 9.7 & 21.5 & 10.8 \\
\hline 18 & 10.2 & 22.5 & 11.2 & 59 & 10.4 & 23.0 & 10.2 & 100 & 10.5 & 23.3 & 10.3 \\
\hline 19 & 10.4 & 24.0 & 10.4 & 60 & 11.0 & 24.8 & 10.3 & 101 & 10.1 & 23.0 & 9.5 \\
\hline 20 & 10.4 & 23.4 & 10.6 & 61 & 9.5 & 21.6 & 9.4 & 102 & 10.2 & 22.4 & 9.9 \\
\hline 21 & 10.5 & 24.1 & 9.6 & 62 & 10.3 & 23.4 & 10.1 & 103 & 10.3 & 23.5 & 10.4 \\
\hline 22 & 10.4 & 23.3 & 10.1 & 63 & 10.2 & 22.5 & 10.0 & 104 & 9.5 & 22.5 & 10.5 \\
\hline 23 & 11.7 & 27.9 & 9.7 & 64 & 9.5 & 20.8 & 9.6 & 105 & 10.0 & 22.3 & 9.7 \\
\hline 24 & 10.4 & 23.2 & 9.6 & 65 & 10.2 & 22.4 & 9.8 & 106 & 9.6 & 20.9 & 9.8 \\
\hline 25 & 9.7 & 22.3 & 10.0 & 66 & 10.5 & 24.0 & 10.2 & 107 & 10.2 & 21.0 & 10.3 \\
\hline 26 & 10.1 & 21.3 & 11.2 & 67 & 9.6 & 21.1 & 10.0 & 108 & 10.0 & 24.8 & 11.1 \\
\hline 27 & 10.2 & 23.4 & 10.4 & 68 & 9.4 & 18.7 & 9.5 & 109 & 9.9 & 22.5 & 10.2 \\
\hline 28 & 9.1 & 18.7 & 9.8 & 69 & 10.1 & 21.1 & 10.0 & 110 & 9.6 & 20.5 & 9.6 \\
\hline 29 & 10.3 & 23.5 & 10.4 & 70 & 10.4 & 23.5 & 9.6 & 111 & 9.6 & 24.0 & 11.4 \\
\hline 30 & 10.2 & 24.3 & 11.0 & 71 & 9.9 & 21.9 & 9.6 & 112 & 9.6 & 21.0 & 9.5 \\
\hline 31 & 10,4 & 22.7 & 9.3 & 72 & 10.3 & 22.2 & 9.5 & 113 & 9.8 & 23.4 & 10.3 \\
\hline 32 & 9.2 & 20.0 & 10.0 & 73 & 10.6 & 23.5 & 9.9 & 114 & 9.7 & 22.2 & 10.3 \\
\hline 33 & 10.0 & 21.5 & 9.8 & 74 & 9.7 & 21.3 & 9.5 & 115 & 10.0 & 21.5 & 10.0 \\
\hline 34 & 10.3 & 23.7 & 10.2 & 75 & 10.2 & 22.5 & 10.2 & 116 & 9.6 & 21.6 & 10.2 \\
\hline 35 & 10.3 & 25.3 & 10.4 & 76 & 9.7 & 21.8 & 10.7 & 117 & 10.3 & 23.0 & 10.0 \\
\hline 36 & 10.0 & 22.4 & 9.7 & 77 & 10.0 & 24.7 & 10.9 & 118 & 10.1 & 21.8 & 9.4 \\
\hline 37 & 9.7 & 19.7 & 9.5 & 78 & 10.6 & 24.6 & 9.6 & 119 & 10.0 & 22.4 & 9.9 \\
\hline 38 & 10.8 & 23.2 & 9.8 & 79 & 9.4 & 20.6 & 10.2 & 120 & 10.5 & 23.0 & 9.5 \\
\hline 39 & 9.7 & 21.2 & 10.5 & 80 & 9.5 & 20.1 & 10.0 & 121 & 9.4 & 20.0 & 10.0 \\
\hline 40 & 10.1 & 22.1 & 10.7 & 81 & 9.8 & 22.3 & 10.9 & 122 & 10.5 & 20.2 & 9.0 \\
\hline 41 & 9.8 & 21.8 & 10.3 & 82 & 9.8 & 22.3 & 10.5 & 123 & 10.1 & 22.7 & 10.0 \\
\hline
\end{tabular}


TABLE No. 5-First generation of Florida-grown Cerion viaregis from Colony $E$-continued.

\begin{tabular}{|c|c|c|c|c|c|c|c|c|c|c|c|}
\hline \multirow{2}{*}{$\begin{array}{l}\text { Serial } \\
\text { No. }\end{array}$} & \multirow{2}{*}{$\begin{array}{l}\text { No. of } \\
\text { whorls. }\end{array}$} & \multicolumn{2}{|c|}{$\begin{array}{l}\text { Measurements } \\
\text { of shells. }\end{array}$} & \multirow{2}{*}{$\begin{array}{l}\text { Serial } \\
\text { No. }\end{array}$} & \multirow{2}{*}{$\begin{array}{l}\text { No. of } \\
\text { whorls. }\end{array}$} & \multicolumn{2}{|c|}{$\begin{array}{l}\text { Measurements } \\
\text { of shells. }\end{array}$} & \multirow{2}{*}{$\begin{array}{l}\text { Serial } \\
\text { No. }\end{array}$} & \multirow{2}{*}{$\begin{array}{l}\text { No. of } \\
\text { whorls. }\end{array}$} & \multicolumn{2}{|c|}{$\begin{array}{l}\text { Measurements } \\
\text { of shells. }\end{array}$} \\
\hline & & Alt. & Diam. & & & Alt. & Diam. & & & Alt. & Diam. \\
\hline & & $m m$ & $m m$ & & & $m m$. & $m m$ & & & $m m$. & $m m$. \\
\hline 124 & 10.2 & 24.5 & 9.4 & 168 & 10.0 & 24.0 & 10.4 & 212 & 10.2 & 22.0 & 9.5 \\
\hline 125 & 9.3 & 19.7 & 10.3 & 169 & 9.5 & 20.7 & 9.8 & 213 & 9.5 & 21.5 & 9.8 \\
\hline 126 & 9.6 & 21.9 & 9.5 & 170 & 10.1 & 24.1 & 10.3 & 214 & 10.0 & 23.1 & 10.5 \\
\hline 127 & 10.2 & 23.2 & 10.2 & 171 & 10.0 & 22.6 & 9.7 & 215 & 9.8 & 21.3 & 9.7 \\
\hline 128 & 10.5 & 24.4 & 9.6 & 172 & 12.0 & 21.7 & 9.9 & 216 & 10.8 & 25.3 & 10.0 \\
\hline 129 & 10.0 & 22.1 & 10.3 & 173 & 10.0 & 23.2 & 10.0 & 217 & 10.0 & 23.4 & 10.1 \\
\hline 130 & 9.2 & 19.6 & 9.5 & 174 & 9.7 & 20.9 & 9.4 & 218 & 10.3 & 23.3 & 10.6 \\
\hline 131 & 10.0 & 22.4 & 10.5 & 175 & 10.7 & 25.5 & 10.0 & 219 & 10.0 & 22.1 & 9.9 \\
\hline 132 & 10.2 & 23.2 & 9.6 & 176 & 9.1 & 20.0 & 10.2 & 220 & 9.7 & 21.1 & 9.9 \\
\hline 133 & 10.2 & 23.5 & 10.7 & 177 & 9.7 & 21.5 & 9.6 & 221 & 10.1 & 23.7 & 10.6 \\
\hline 134 & 10.0 & 22.3 & 9.8 & 178 & 9.7 & 20.7 & 9.5 & 222 & 10.0 & 23.8 & 11.2 \\
\hline 135 & 10.9 & 26.4 & 9.9 & 179 & 10.3 & 24.0 & 9.2 & 223 & 9.7 & 20.5 & 10.0 \\
\hline 136 & 9.6 & 20.5 & 10.0 & 180 & 10.3 & 22.1 & 9.6 & 224 & 9.5 & 22.2 & 11.0 \\
\hline 137 & 11.3 & 24.7 & 9.1 & 181 & 10.2 & 23.9 & 9.9 & 225 & 10.4 & 21.3 & 10.0 \\
\hline 138 & 10.5 & 23.0 & 10.0 & 182 & 9.6 & 20.7 & 10.0 & 226 & 10.4 & 22.5 & 10.0 \\
\hline 139 & 10.0 & 21.7 & 10.1 & 183 & 10.1 & 23.0 & 11.0 & 227 & 9.4 & 19.8 & 10.3 \\
\hline 140 & 10.6 & 23.6 & 10.0 & 184 & 10.0 & 23.2 & 10.5 & 228 & 9.8 & 21.6 & 10.1 \\
\hline 141 & 10.1 & 23.4 & 10.3 & 185 & 9.6 & 22.2 & 9.6 & 229 & 9.2 & 21.0 & 10.5 \\
\hline 142 & 10.2 & 24.4 & 9.9 & 186 & 10.1 & 23.5 & 10.6 & 230 & 10.6 & 25.1 & 10.3 \\
\hline 143 & 9.9 & 22.3 & 9.9 & 187 & 9.6 & 20.0 & 8.8 & 231 & 9.6 & 22.6 & 10.6 \\
\hline 144 & 9.8 & 21.5 & 10.4 & 188 & 10.0 & 22.0 & 9.5 & 232 & 10.0 & 23.0 & 10.2 \\
\hline 145 & 9.7 & 21.8 & 9.7 & 189 & 10.0 & 21.9 & 9.5 & 233 & 10.8 & 23.4 & 10.0 \\
\hline 146 & 9.6 & 21.4 & 10.3 & 190 & 10.0 & 20.3 & 10.2 & 23 & 10.8 & 22.5 & 9.9 \\
\hline 147 & 10.5 & 24.3 & 10.2 & 191 & 10.6 & 24.0 & 9.6 & 235 & 9.7 & 19.3 & 9.7 \\
\hline 148 & 10.2 & 23.5 & 10.0 & 192 & 9.5 & 21.6 & 9.6 & 23 & 10.1 & 23.0 & 10.0 \\
\hline 149 & 10.9 & 24.3 & 9.9 & 193 & 9.9 & 21.7 & 10.0 & 237 & 9.7 & 21.3 & 10.1 \\
\hline 150 & 9.9 & 22.7 & 10.0 & 194 & 10.3 & 23.9 & 10.3 & 238 & 9.7 & 21.1 & 9.0 \\
\hline 151 & 10.0 & 21.8 & 9.4 & 195 & 10.6 & 23.5 & 9.9 & 239 & 10.1 & 20.7 & 10.5 \\
\hline 152 & 10.1 & 20.4 & 10.3 & 196 & 10.1 & 24.2 & 10.0 & 240 & 9.9 & 22.0 & 9.3 \\
\hline 153 & 10.3 & 23.4 & 9.7 & 197 & 10.1 & 24.0 & 10.9 & 241 & 8.9 & 20.0 & 10.2 \\
\hline 154 & 11.1 & 24.0 & 10.0 & 198 & 10.2 & 24.1 & 10.2 & 242 & 9.9 & 22.8 & 10.7 \\
\hline 155 & 10.0 & 21.1 & 9.5 & 199 & 10.4 & 22.4 & 9.7 & 243 & 10.2 & 23.3 & 9.5 \\
\hline 156 & 9.8 & 21.0 & 10.0 & 200 & 10.2 & 22.5 & 10.6 & 244 & 9.3 & 20.3 & 9.7 \\
\hline 157 & 10.1 & 21.7 & 10.3 & 201 & 9.4 & 21.1 & 10.0 & 245 & 9.5 & 20.8 & 9.6 \\
\hline 158 & 10.2 & 22.0 & 10.2 & 202 & 10.2 & 23.0 & 10.1 & 246 & 10.2 & 22.4 & 10.0 \\
\hline 159 & 10.0 & 22.4 & 9.9 & 203 & 9.6 & 20.3 & 9.5 & 247 & 9.4 & 20.0 & 9.1 \\
\hline 160 & 9.5 & 21.2 & 10.0 & 204 & 10.0 & 21.9 & 9.5 & 248 & 9.6 & 23.3 & 10.0 \\
\hline 161 & 10.3 & 23.0 & 10.1 & 205 & 9.5 & 20.8 & 9.8 & 249 & 10.4 & 23.8 & 10.0 \\
\hline 162 & 9.4 & 22.0 & 9.7 & 206 & 10.1 & 23.5 & 10.0 & 250 & 10.2 & 23.9 & 10.2 \\
\hline 163 & 10.1 & 21.0 & 9.5 & 207 & 10.4 & 24.7 & 10.4 & & & & \\
\hline 164 & 9.8 & 21.9 & 10.0 & 208 & 10.0 & 21.0 & 9.8 & Average. & 10.05 & 22.47 & 10.02 \\
\hline 165 & 9.7 & 22.0 & 9.4 & 209 & 10.1 & 23.7 & 10.7 & Greatest. & 12.0 & 27.9 & 11.4 \\
\hline 166 & 10.2 & 21.5 & 9.7 & 210 & 10.3 & 22.8 & 10.0 & Least... & 8.9 & 18.7 & 8.8 \\
\hline 167 & 10.2 & 24.5 & 10.5 & 211 & 10.4 & 22.2 & 10.1 & & & & \\
\hline
\end{tabular}

In May 1916 Colony E resembled Colony A in development. The mollusks were spreading over a wide area and many young and adult shells were in evidence everywhere. The same conditions obtained in 1917, and in January 1919 we were able to state that this colony was spreading and multiplying rapidly. Toung and old could be seen everywhere on the ground. Most of the old were partly burrowed in the tilted position, feeding or ovipositing. The extreme young, as usual, were mostly about the base of tussocks of grass. Half-grown specimens were also plentiful on the moist ground and on the lower portion of the bushes and grass. 
TABLE No. 6.-Measurements of the first generation of Florida-grown Cerion viaregis from Loggerhead Key Colony $F$.

\begin{tabular}{|c|c|c|c|c|c|c|c|c|c|c|c|}
\hline \multirow{2}{*}{$\begin{array}{c}\text { Serial } \\
\text { No. }\end{array}$} & \multirow{2}{*}{$\begin{array}{l}\text { No. of } \\
\text { whorls. }\end{array}$} & \multicolumn{2}{|c|}{$\begin{array}{l}\text { Measurements } \\
\text { of shells. }\end{array}$} & \multirow{2}{*}{$\begin{array}{c}\text { Serial } \\
\text { No. }\end{array}$} & \multirow{2}{*}{$\begin{array}{l}\text { No. of } \\
\text { whorls. }\end{array}$} & \multicolumn{2}{|c|}{$\begin{array}{l}\text { Measurements } \\
\text { of shells. }\end{array}$} & \multirow{2}{*}{$\begin{array}{c}\text { Serial } \\
\text { No. }\end{array}$} & \multirow{2}{*}{$\begin{array}{l}\text { No. of } \\
\text { whorls. }\end{array}$} & \multicolumn{2}{|c|}{$\begin{array}{l}\text { Measurements } \\
\text { of shells. }\end{array}$} \\
\hline & & Alt. & Diam. & & & Alt. & Diam. & & & Alt. & Diam. \\
\hline 1 & 10.5 & $\begin{array}{c}m m . \\
23.3\end{array}$ & $\begin{array}{c}m m . \\
11.2\end{array}$ & 13 & 10.0 & $m m$. & $m m$. & 25 & 10.3 & $m m$. & $\mathrm{mm}$. \\
\hline 2 & 9.6 & 22.0 & 10.5 & 14 & 10.1 & 21.6 & 11.7 & 26 & 10.2 & 22.3 & 12.0 \\
\hline 3 & 10.2 & 22.6 & 12.5 & 15 & 10.2 & 23.5 & 12.0 & 27 & 9.8 & 21.1 & 11.1 \\
\hline 4 & 10.0 & 22.6 & 11.6 & 16 & 9.7 & 21.4 & 11.4 & 28 & 10.4 & 23.0 & 11.2 \\
\hline 5 & 10.5 & 23.5 & 12.0 & 17 & 10.4 & 23.5 & 11.8 & 29 & 9.4 & 20.7 & 12.4 \\
\hline 6 & 10.1 & 22.0 & 11.4 & 18 & 10.5 & 23.5 & 12.0 & 30 & 10.0 & 23.2 & 12.5 \\
\hline 7 & 10.3 & 22.5 & 11.8 & 19 & 10.2 & 22.5 & 11.5 & & & & \\
\hline 8 & 10.5 & 23.4 & 11.0 & 20 & 9.7 & 21.3 & 12.2 & Average. & 10.15 & 22.53 & 11.68 \\
\hline 9 & 10.3 & 22.0 & 11.5 & 21 & 10.6 & 24.2 & 12.0 & Greatest. & 10.6 & 24.2 & 12.5 \\
\hline 10 & 9.4 & 20.0 & 11.7 & 22 & 10.6 & 23.3 & 11.8 & Least. . . & 9.4 & 20.0 & 10.5 \\
\hline 11 & 10.6 & 23.0 & 11.6 & 23 & 10.2 & 22.8 & 11.3 & & & & \\
\hline 12 & 9.8 & 23.8 & 11.0 & 24 & 10.4 & 23.5 & 12.0 & & & & \\
\hline
\end{tabular}

TABLE No. 7.-Measurements of the first generation of Florida-grown Cerion viaregis from Loggerhead Key Colony $F$.

\begin{tabular}{|c|c|c|c|c|c|c|c|c|c|c|c|}
\hline \multirow{2}{*}{$\begin{array}{l}\text { Serial } \\
\text { No. }\end{array}$} & \multirow{2}{*}{$\begin{array}{l}\text { No. of } \\
\text { whorls. }\end{array}$} & \multicolumn{2}{|c|}{$\begin{array}{l}\text { Measurements } \\
\text { of shells. }\end{array}$} & \multirow{2}{*}{$\begin{array}{l}\text { Serial } \\
\text { No. }\end{array}$} & \multirow{2}{*}{$\begin{array}{l}\text { No. of } \\
\text { whorls. }\end{array}$} & \multicolumn{2}{|c|}{$\begin{array}{l}\text { Measurements } \\
\text { of shells. }\end{array}$} & \multirow{2}{*}{$\begin{array}{l}\text { Serial } \\
\text { No. }\end{array}$} & \multirow{2}{*}{$\begin{array}{l}\text { No. of } \\
\text { whorls. }\end{array}$} & \multicolumn{2}{|c|}{$\begin{array}{l}\text { Measurements } \\
\text { of shells. }\end{array}$} \\
\hline & & Alt. & Diam. & & & Alt. & Diam. & & & Alt. & Diam. \\
\hline 1 & 9.8 & $\begin{array}{l}m m . \\
20.9\end{array}$ & $\begin{array}{l}m m . \\
11.0\end{array}$ & 36 & 10.1 & $\begin{array}{l}m m . \\
20.7\end{array}$ & $\begin{array}{l}m m . \\
9.9\end{array}$ & 71 & 10.6 & $\begin{array}{l}m m . \\
23.5\end{array}$ & $\begin{array}{l}m m . \\
10.7\end{array}$ \\
\hline 2 & 10.0 & 19.7 & 10.8 & 37 & 10.5 & 23.5 & 11.1 & 72 & 10.3 & 22.2 & 10.6 \\
\hline 3 & 10.0 & 22.6 & 12.0 & 38 & 10.0 & 22.3 & 10.5 & 73 & 10.5 & 22.7 & 10.7 \\
\hline 4 & 10.0 & 22.7 & 10.4 & 39 & 10.0 & 22.7 & 11.1 & 74 & 9.9 & 20.6 & 10.0 \\
\hline 5 & 10.1 & 22.1 & 10.6 & 40 & 10.5 & 23.2 & 10.1 & 75 & 10.3 & 22.7 & 10.1 \\
\hline 6 & 10.4 & 23.0 & 11.6 & 41 & 10.0 & 21.8 & 9.9 & 76 & 10.0 & 21.5 & 10.8 \\
\hline 7 & 10.5 & 22.5 & 10.9 & 42 & 10.3 & 22.4 & 10.0 & 77 & 10.6 & 24.9 & 11.5 \\
\hline 8 & 10.2 & 22.7 & 11.0 & 43 & 10.4 & 21.9 & 10.3 & 78 & 10.2 & 23.0 & 10.5 \\
\hline 9 & 10.4 & 21.5 & 11.0 & 44 & 10.4 & 23.8 & 11.1 & 79 & 10.3 & 23.4 & 11.1 \\
\hline 10 & 10.2 & 22.1 & 10.6 & 45 & 9.6 & 21.7 & 11.0 & 80 & 10.5 & 23.2 & 10.1 \\
\hline 11 & 10.4 & 21.3 & 10.7 & 46 & 10.3 & 22.1 & 10.1 & 81 & 10.4 & 23.0 & 10.5 \\
\hline 12 & 10.3 & 22.2 & 10.6 & 47 & 10.2 & 24.5 & 10.7 & 82 & 9.6 & 21.5 & 10.7 \\
\hline 13 & 10.1 & 22.3 & 10.5 & 48 & 10.9 & 24.1 & 10.5 & 83 & 10.1 & 21.9 & 10.0 \\
\hline 14 & 10.3 & 24.0 & 11.7 & 49 & 9.7 & 20.3 & 9.6 & 84 & 10.1 & 22.4 & 10.3 \\
\hline 15 & 10.1 & 21,3 & 9.4 & 50 & 10.2 & 22.6 & 10.3 & 85 & 10.2 & 22.1 & 10.6 \\
\hline 16 & 10.2 & 23.5 & 10.8 & 51 & 10.0 & 21.8 & 10.5 & 86 & 10.0 & 21.9 & 9.6 \\
\hline 17 & 9.5 & 19.7 & 10.8 & 52 & 10.0 & 22.1 & 10.7 & 87 & 10.3 & 27.7 & 10.4 \\
\hline 18 & 9.8 & 21.3 & 10.5 & 53 & 10.6 & 23.2 & 10.0 & 88 & 10.3 & 22.7 & 10.9 \\
\hline 19 & 9.6 & 22.0 & 10.8 & 54 & 10.6 & 24.1 & 10.5 & 89 & 10.1 & 22.0 & 10.5 \\
\hline 20 & 9.6 & 21.7 & 11.4 & 55 & 9.8 & 21.5 & 11.0 & 90 & 10.4 & 23.7 & 11.0 \\
\hline 21 & 10.2 & 21.1 & 10.1 & 56 & 9.9 & 22.6 & 10.0 & 91 & 10.1 & 23.1 & 10.9 \\
\hline 22 & 9.7 & 20.3 & 10.5 & 57 & 10.6 & 24.0 & 10.7 & 92 & 11.0 & 24.7 & 10.4 \\
\hline 23 & 9.8 & 21.0 & 10.3 & 58 & 10.1 & 22.8 & 10.6 & 93 & 10.6 & 24.5 & 11.3 \\
\hline 24 & 9.7 & 21.3 & 9.7 & 59 & 10.3 & 22.7 & 11.2 & 94 & 10.0 & 22.6 & 10.8 \\
\hline 25 & 10.3 & 24.4 & 10.5 & 60 & 10.5 & 22.5 & 10.4 & 95 & 10.2 & 23.0 & 9.6 \\
\hline 26 & 10.3 & 23.5 & 11.3 & 61 & 10.2 & 21.4 & 10.7 & 96 & 10.4 & 22.1 & 10.9 \\
\hline 27 & 10,4 & 21.8 & 10.0 & 62 & 9.8 & 21.3 & 10.3 & 97 & 10.7 & 25.7 & 10.7 \\
\hline 28 & 10.3 & 22.4 & 10.4 & 63 & 10.4 & 23.3 & 10.5 & 98 & 10.6 & 21.7 & 10.5 \\
\hline 29 & 10.5 & 24.9 & 10.0 & 64 & 10.0 & 21.8 & 10.1 & 99 & 10.5 & 23.2 & 10.6 \\
\hline 30 & 10.2 & 21.9 & 10.8 & 65 & 10.0 & 23.8 & 10.6 & 100 & 11.0 & 23.8 & 11.1 \\
\hline 31 & 10.3 & 22.3 & 10.5 & 66 & 10.6 & 24.2 & 10.6 & & & & \\
\hline 32 & 11.5 & 26.8 & 11.6 & 67 & 10.0 & 23.1 & 11.3 & Average. & 10.2 & 22.59 & 10.6 \\
\hline 33 & 9.6 & 22.3 & 10.6 & 68 & 9.8 & 21.3 & 10.3 & Greatest. & 11.5 & 27.7 & 12.0 \\
\hline 34 & 9.6 & 23.7 & 11.8 & 69 & 10.5 & 23.3 & 10.7 & Least... & 9.5 & 19.7 & 9.4 \\
\hline 35 & 10.0 & 20.6 & 10.4 & 70 & 10.0 & 22.5 & 10.3 & & & & \\
\hline
\end{tabular}


The Loggerhead Key Colony F.

This colony consisted of 500 specimens imported in 1914 from Bastian Point, Andros, the same locality from which the original specimens of Cerion viaregis were obtained. The colony was placed at the south end of Loggerhead Key, S. $24^{\circ} \mathrm{W}$., from the long entrance stake and S. $80^{\circ} \mathrm{W}$. from the double stake which marks Colony E. The colony was marked by a stake bearing a tag with the legend "Bastian Point, Andros, 1914."

In June 1915 the colony was thriving, although no young were observed, and it was deemed best not to disturb the ground in order to see if any were present.

In May 1916 we gathered 300 tips of the first generation and these were planted as Colony $\mathrm{M}$.

In July 1917 we measured, photographed, and marked 30 adults and 7 almost full-grown specimens and planted them with Colony M. Table 6 gives the measurements.

In January 1919 we gathered, measured, and photographed 100 additional first generation Florida-grown specimens of Colony F. Table 7 gives the measurements; the photographs are shown on plates 22 and 23 and No. 85-100 on plate 24.

The Loggerhead Key Colony G.

The original planting of this colony consisted of 300 young specimens gathered from Colony $\mathrm{E}$ in April 1914, some of which were figured on plate 5, upper figure, and the 3 full-grown and 3 nearly full-grown individuals on plate 3 , top row of the 1915 report. This colony is placed in a small meadow a little to the northeast of Colony E. It

TABLE No. 8.-Measurements of the first generation of Florida-grown Cerion viaregis from Loggerhead Key Colony $K$.

\begin{tabular}{|c|c|c|c|c|c|c|c|c|c|c|c|}
\hline \multirow{2}{*}{$\begin{array}{c}\text { Serial } \\
\text { No. }\end{array}$} & \multirow{2}{*}{$\begin{array}{l}\text { No. of } \\
\text { whorls. }\end{array}$} & \multicolumn{2}{|c|}{$\begin{array}{l}\text { Measurements } \\
\text { of shells. }\end{array}$} & \multirow{2}{*}{$\begin{array}{l}\text { Serial } \\
\text { No. }\end{array}$} & \multirow{2}{*}{$\begin{array}{l}\text { No. of } \\
\text { whorls. }\end{array}$} & \multicolumn{2}{|c|}{$\begin{array}{l}\text { Measurements } \\
\text { of shells. }\end{array}$} & \multirow{2}{*}{$\begin{array}{c}\text { Serial } \\
\text { No. }\end{array}$} & \multirow{2}{*}{$\begin{array}{l}\text { No. of } \\
\text { whorls. }\end{array}$} & \multicolumn{2}{|c|}{$\begin{array}{l}\text { Measurements } \\
\text { of shells. }\end{array}$} \\
\hline & & Alt. & Diam. & & & Alt. & Diam. & & & Alt. & Diam. \\
\hline 1 & 10.3 & $\begin{array}{l}m m . \\
20.0\end{array}$ & $\begin{array}{c}m m . \\
9.8\end{array}$ & 19 & & mm. & $m m$. & & & $m m$. & $m m$ \\
\hline 2 & 10.0 & 22.8 & 10.9 & $\begin{array}{l}19 \\
20\end{array}$ & $\begin{array}{l}10.9 \\
10.0\end{array}$ & 24.2 & 11.0 & $\begin{array}{l}37 \\
38\end{array}$ & 9.8 & 21.1 & 9.6 \\
\hline 3 & 10.5 & 24.4 & 11.2 & 21 & $\begin{array}{l}10.0 \\
10.6\end{array}$ & $\begin{array}{l}22.0 \\
24.8\end{array}$ & 10.0 & $\begin{array}{l}38 \\
39\end{array}$ & 9.8 & 22.5 & 10.8 \\
\hline 4 & 10.1 & 22.7 & 11.1 & 22 & 10.3 & 24.8 & 10.2 & $\begin{array}{l}39 \\
40\end{array}$ & 10.2 & 22.8 & 10.0 \\
\hline 5 & 9.5 & 21.4 & 10.4 & 23 & $\begin{array}{r}10.8 \\
9.5\end{array}$ & $\begin{array}{l}23.6 \\
20.0\end{array}$ & 10.0 & 40 & 9.5 & 21.5 & 10.4 \\
\hline 6 & 10.8 & 23.2 & 11.7 & 24 & 10.5 & $\begin{array}{l}20.0 \\
22.6\end{array}$ & 9.8 & 41 & 10.8 & 23.2 & 10.2 \\
\hline 7 & 9.8 & 20.0 & 11.0 & 25 & 101 & 22.6 & 10.7 & 42 & 9.7 & 21.0 & 9.5 \\
\hline 8 & 10.2 & 23.6 & 11.3 & 26 & 10.3 & $\begin{array}{l}22.2 \\
23.6\end{array}$ & 10.7 & 43 & 9.4 & 21.1 & 10.6 \\
\hline 9 & 10.3 & 21.9 & 10.8 & 27 & 10.2 & $\begin{array}{l}23.6 \\
23.0\end{array}$ & 11.0 & 44 & 11.2 & 26.0 & 10.7 \\
\hline 10 & 10.8 & 23.2 & 10.0 & 28 & $\begin{array}{r}9.2 \\
9.6\end{array}$ & $\begin{array}{l}23.0 \\
20.2\end{array}$ & 10.8 & 45 & 10.7 & 23.7 & 10.3 \\
\hline 11 & 10.1 & 22.3 & 10.0 & 29 & 9.9 & $\begin{array}{l}20.2 \\
22.8\end{array}$ & 10.3 & 46 & 10.0 & 21.5 & 11.4 \\
\hline 12 & 9.2 & 20.4 & 9.6 & 30 & 10.2 & 22.0 & 10.1 & 47 & 10.9 & 23.8 & 10.1 \\
\hline 13 & 10.9 & 24.0 & 9.6 & 31 & 10.2 & 21.8 & 10.1 & 48 & 9.9 & 22.3 & 9.5 \\
\hline 14 & 10.2 & 23.0 & 10.5 & 32 & 9.2 & 20.0 & $\begin{array}{r}10.0 \\
9.8\end{array}$ & 49 & 9.9 & 21.1 & 9.8 \\
\hline 15 & 10.4 & 23.5 & 10.2 & 33 & 10.8 & 24.8 & $\begin{array}{r}9.8 \\
10.8\end{array}$ & Average & 10.21 & 22.53 & 10.37 \\
\hline 16 & 10.7 & 22.3 & 10.1 & 34 & 10.1 & 23.7 & 10.2 & Averatest. & 10.21 & & \\
\hline 17 & 11.2 & 25.5 & 10.4 & 35 & 10.3 & 22.0 & 10.1 & Least. . & 9.2 & 26.0 & 11.7 \\
\hline 18 & 10.4 & 22.9 & 10.2 & 36 & 10.2 & 22.0 & 10.7 & & & 20.0 & 9.5 \\
\hline
\end{tabular}


is on a ridge in a scanty growth of Uniola paniculata and the place is marked by a stake bearing a tag with the legend "Cerions, Z." In June 1915 we gathered 49 adult or almost adult specimens from this colony. These were measured, photographed, and planted in a little meadow to the west of Colony F, at a place marked with a stake bearing the legend "Cerions, 1915, K." The measurements are shown in table 8, while the figures appear on plate 25 .

In May 1916 we gathered 78 additional adult specimens of the first generation of Florida-grown individuals in this colony, which were photographed and returned to the stake marking this colony. For measurements of these see table 9, and for the pictures see plates 26 and 27 and figures $73-78$ of plate 24 .

TABLE No. 9.-Measurements of the first generation of Florida-grown Cerion viaregis from Loggerhead Key Colony $G$.

\begin{tabular}{|c|c|c|c|c|c|c|c|c|c|c|c|}
\hline \multirow{2}{*}{$\begin{array}{l}\text { Serial } \\
\text { No. }\end{array}$} & \multirow{2}{*}{$\begin{array}{l}\text { No. of } \\
\text { whorls. }\end{array}$} & \multicolumn{2}{|c|}{$\begin{array}{l}\text { Measurements } \\
\text { of shells. }\end{array}$} & \multirow{2}{*}{$\begin{array}{l}\text { Serial } \\
\text { No. }\end{array}$} & \multirow{2}{*}{$\begin{array}{l}\text { No. of } \\
\text { whorls. }\end{array}$} & \multicolumn{2}{|c|}{$\begin{array}{l}\text { Measurements } \\
\text { of shells. }\end{array}$} & \multirow{2}{*}{$\begin{array}{l}\text { Serial } \\
\text { No. }\end{array}$} & \multirow{2}{*}{$\begin{array}{l}\text { No. of } \\
\text { whorls. }\end{array}$} & \multicolumn{2}{|c|}{$\begin{array}{l}\text { Measurements } \\
\text { of shells. }\end{array}$} \\
\hline & & Alt. & Diam. & & & Alt. & Diam. & & & Alt. & Diam. \\
\hline & 9.7 & $\begin{array}{l}m m . \\
21.9\end{array}$ & $\begin{array}{c}m m . \\
10.6\end{array}$ & & 10.3 & $\begin{array}{l}m m . \\
23.5\end{array}$ & $\begin{array}{l}m m . \\
10.5\end{array}$ & 57 & 10.5 & $\begin{array}{l}m m . \\
24.0\end{array}$ & $m m$. \\
\hline $\begin{array}{l}1 \\
2\end{array}$ & $\begin{array}{r}9.7 \\
10.3\end{array}$ & $\begin{array}{l}21.9 \\
24.8\end{array}$ & $\begin{array}{l}10.6 \\
11.0\end{array}$ & $\begin{array}{l}29 \\
30\end{array}$ & $\begin{array}{l}10.5 \\
10.6\end{array}$ & $\begin{array}{l}23.0 \\
23.4\end{array}$ & $\begin{array}{l}10.0 \\
10.2\end{array}$ & 58 & $\begin{array}{l}10.0 \\
10.2\end{array}$ & $\begin{array}{l}24.0 \\
22.0\end{array}$ & $\begin{array}{l}11.1 \\
10.1\end{array}$ \\
\hline 3 & 10.4 & 23.5 & 10.2 & 31 & 9.9 & 24.0 & 11.2 & 59 & 9.8 & 21.3 & 10.5 \\
\hline 4 & 10.6 & 23.7 & 10.5 & 32 & 10.0 & 22.8 & 10.0 & 60 & 9.7 & 22.0 & 10.8 \\
\hline$\overline{5}$ & 9.7 & 21.3 & 10.6 & 33 & 11.1 & 25.5 & 10.5 & 61 & 10.0 & 22.4 & 10.1 \\
\hline 6 & 10.2 & 24.0 & 10.6 & 34 & 10.7 & 24.3 & 10.6 & 62 & 10.8 & 24.1 & 11.0 \\
\hline 7 & 10.6 & 23.5 & 11.0 & 35 & 10.4 & 24.0 & 11.0 & 63 & 10.6 & 24.0 & 10.0 \\
\hline 8 & 10.0 & 20.9 & 10.2 & 36 & 10.3 & 23.1 & 10.2 & 64 & 10.3 & 24.0 & 10.5 \\
\hline 9 & 10.0 & 24.1 & 10.1 & 37 & 9.7 & 23.0 & 11.2 & 65 & 9.9 & 22.3 & 10.1 \\
\hline 10 & 9.6 & 21.0 & 10.1 & 38 & 10.1 & 23.3 & 10.8 & 66 & 10.2 & 23.5 & 10.4 \\
\hline 11 & 9.8 & 22.3 & 11.0 & 39 & 9.3 & 22.1 & 10.3 & 67 & 10.4 & 23.4 & 11.0 \\
\hline 12 & 10.2 & 22.1 & 10.5 & 40 & 9.8 & 22.0 & 11.0 & 68 & 10.1 & 26.0 & 11.0 \\
\hline 13 & 11.2 & 26.0 & 11.6 & 41 & 10.0 & 22.3 & 11.1 & 69 & 10.2 & 23.1 & 10.1 \\
\hline 14 & 9.7 & 21.7 & 11.9 & 42 & 10.5 & 24.0 & 11.0 & 70 & 9.7 & 22.5 & 11.0 \\
\hline 15 & 10.1 & 23.0 & 10.5 & 43 & 9.9 & 22.3 & 11.0 & 71 & 10.5 & 24.9 & 10.9 \\
\hline 16 & 10.3 & 23.7 & 10.2 & 44 & 10.1 & 23.7 & 11.1 & 72 & 10.8 & 24.9 & 11.0 \\
\hline 17 & 10.7 & 25.0 & 11.0 & 45 & 10.8 & 24.0 & 10.6 & 73 & 10.4 & 24.0 & 11.5 \\
\hline 18 & 10.7 & 24.0 & 10.3 & 46 & 10.2 & 24.1 & 10.3 & 74 & 10.6 & 24.6 & 10.3 \\
\hline 19 & 10.6 & 25.0 & 11.0 & 47 & 10.1 & 22.3 & 10.1 & 75 & 10.2 & 22.7 & 10.8 \\
\hline 20 & 10.1 & 25.0 & 11.2 & 48 & 10.1 & 24.5 & 11.1 & 76 & 10.3 & 23.4 & 10.2 \\
\hline 21 & 9.7 & 23.0 & 11.0 & 49 & 10.0 & 22.8 & 11.0 & 77 & 10.1 & 23.0 & 10.6 \\
\hline 22 & 9.5 & 21.5 & 10.1 & 50 & 10.5 & 23.0 & 11.1 & 78 & 10.6 & 25.1 & 11.1 \\
\hline 23 & 9.9 & 23.3 & 11.0 & 51 & 10.0 & 22.5 & 10.1 & & & & \\
\hline 24 & 10.8 & 27.0 & 11.0 & 52 & 9.3 & 21.7 & 10.5 & Average. & 10.2 & 23.39 & 10.7 \\
\hline 25 & 10.1 & 24.0 & 10.3 & 53 & 10.2 & 23.0 & 10.4 & Greatest. & 11.2 & 27.0 & 11.9 \\
\hline 26 & 10.3 & 23.8 & 11.1 & 54 & 10.1 & 23.2 & 10.6 & Least... & 9.3 & 20.9 & 10.0 \\
\hline 27 & 10.1 & 23.1 & 11.1 & 55 & 10.2 & 23.0 & 10.4 & & & & \\
\hline 28 & 10.0 & 23.2 & 11.7 & 56 & 10.3 & 24.6 & 11.1 & & & & \\
\hline
\end{tabular}

In January 1919 we found many shells of various ages scattered over the ground, and the colony, although small, is doing well.

The Loggerhead Key Colony $H$.

On June 8, 1912, a planting of 500 each of Cerion viaregis and Cerion casablancee was made on the south side of the path leading from the light-house to the boat-house on the west shore, in order to determine if these two forms would cross when given an opportunity. 
In May 1913 we observed that several dead Cerion shells, evidently belonging to this colony, were occupied by small hermit crabs in the neighborhood.

In April 1914 we found that part of the ground occupied by this colony had been burned over and quite a number of the shells destroyed. Most of the living shells were in the fringe of live bay cedars. As we did not deem this habitat quite suitable, we cleared the place thoroughly by pulling the cactus and cutting the grass. This exhaustive search resulted in the recovery of 200 Cerion casablancee and 150 Cerion viaregis and a single young tip. We planted all this material in a new location, which will be referred to in the future as Colony I.

In June 1915 quite a number of specimens were discovered in the fringe of bay cedars bordering the west side of the original planting which we overlooked in 1914 . We left these undisturbed.

In May 1916 we found that this colony had again been subjected to a severe burning and it was doubted if anything had survived.

No specimens were seen in 1917.

In January 1919 this place was so heavily overgrown with Uniola paniculata that it was impossible to see anything of Cerions that might have escaped our collecting and the fire.

\section{The Loggerhead Key Colony I.}

This colony (consisting of 200 Cerion viaregis, 150 Cerion casablance, and a single tip which were transferred from Colony $H$ in April 1914) is located in the second meadow northwest of Colony $\mathrm{E}$, in a coarse calcareous sand plain having a good stand of Sporobolus virginicus, the whole being fringed by bay cedars.

The colony was doing well in June 1915, but in May 1916 we found 55 of the planted mollusks dead; of these 28 belonged to Cerion viaregis and 27 to Cerion casablance; 18 young individuals of various sizes were also observed.

In July 1917 we discovered some adult first generation Floridagrown Cerions in this colony, but all were readily referable to either Cerion casablance or Cerion viaregis. Apparently no crossing had taken place.

In January 1919 we gathered up all the material discoverable in this planting and secured 58 marked and 43 unmarked specimens of Cerion viaregis and 54 marked and 105 unmarked Cerion casablance. All the unmarked specimens, which represent the first generation of Floridagrown material, were at once referable to one or the other of the two species; no intermediates of any kind appeared. It seems reasonable, therefore, to believe that these two species do not cross. This is not at all surprising when one considers the differences in the anatomical structures, as pointed out in the anatomical discussion of the various forms transplanted. 


\section{The Lgggerhead Key Colony K.}

In June 1915 we gathered 646 specimens of the first generation of Florida-grown individuals at Colony $\mathrm{E}$, of which 250 were photographed and measured and reported under that colony. The entire lot was then planted in a little meadow to the west of Colony $\mathrm{E}$, which is separated from Colony $\mathrm{K}$ by a fringe of bay cedars. They are in the north end of this meadow, the ground being covered by a mixed growth of Uniola paniculata and Sporobolus virginicus. The planting is marked by a stake bearing a tag with the legend "Cerions, 1915, K."

TABLE No. 10. -Measurements of the second generation of Florida-grown Cerion viaregis from Loggerhead Key Colony $K$.

\begin{tabular}{|c|c|c|c|c|c|c|c|c|c|c|c|}
\hline \multirow{2}{*}{$\begin{array}{l}\text { Serial } \\
\text { No. }\end{array}$} & \multirow{2}{*}{$\begin{array}{c}\text { No. of } \\
\text { whorls. }\end{array}$} & \multicolumn{2}{|c|}{$\begin{array}{l}\text { Measurements } \\
\text { of shells. }\end{array}$} & \multirow{2}{*}{$\begin{array}{l}\text { Serial } \\
\text { No. }\end{array}$} & \multirow{2}{*}{$\begin{array}{l}\text { No. of } \\
\text { whorls. }\end{array}$} & \multicolumn{2}{|c|}{$\begin{array}{l}\text { Measurements } \\
\text { of shells. }\end{array}$} & \multirow{2}{*}{$\begin{array}{l}\text { Serial } \\
\text { No. }\end{array}$} & \multirow{2}{*}{$\begin{array}{l}\text { No. of } \\
\text { whorls. }\end{array}$} & \multicolumn{2}{|c|}{$\begin{array}{l}\text { Measurements } \\
\text { of shells. }\end{array}$} \\
\hline & & Alt. & Diam. & & & Alt. & Diam. & & & Alt. & Diam. \\
\hline 1 & 9.5 & $\begin{array}{c}m m . \\
22.5\end{array}$ & $\begin{array}{l}m m . \\
10.8\end{array}$ & 36 & 10.0 & $\begin{array}{c}m m . \\
22.3\end{array}$ & $\begin{array}{l}m m . \\
11.1\end{array}$ & 71 & 10.1 & $\begin{array}{l}m m . \\
22.0\end{array}$ & $\begin{array}{l}m m . \\
10.8\end{array}$ \\
\hline 2 & 10.0 & 23.0 & 10.0 & 37 & 9.9 & 20.7 & 11.3 & 72 & 10.2 & 22.2 & 10.8 \\
\hline 3 & 10.4 & 23.5 & 10.1 & 38 & 10.6 & 22.9 & 10.1 & 73 & 10.0 & 22.4 & 11.8 \\
\hline 4 & 10.0 & 21.4 & 10.8 & 39 & 10.1 & 21.9 & 10.5 & 74 & 9.6 & 22.8 & 11.4 \\
\hline 5 & 10.5 & 24.8 & 10.7 & 40 & 10.5 & 23.0 & 11.2 & 75 & 10.3 & 22.2 & 10.0 \\
\hline 6 & 10.4 & 24.1 & 11.0 & 41 & 10.5 & 24.0 & 11.3 & 76 & 11.0 & 22.7 & \\
\hline 7 & 10.0 & 22.3 & 10.7 & 42 & 10.6 & 23.0 & 10.0 & 77 & 10.0 & 21.5 & 11.0 \\
\hline 8 & 10.0 & 23.7 & 11.1 & 43 & 10.0 & 22.1 & 10.6 & 78 & 10.1 & 22.0 & 12.0 \\
\hline 9 & 10.5 & 24.4 & 11.3 & 44 & 10.2 & 22.6 & 10.7 & 79 & 10.5 & 24.2 & 11.0 \\
\hline 10 & 10.3 & 23.0 & 10.6 & 45 & 10.6 & 25.4 & 10.2 & 80 & 10.0 & 22.3 & 10.4 \\
\hline 11 & 10.2 & 24.5 & 11.7 & 46 & 10.1 & 22.4 & 11.2 & 81 & 10.1 & 23.1 & 10.2 \\
\hline 12 & 10.0 & 22.2 & 10.3 & 47 & 10.5 & 23.3 & 10.6 & 82 & 9.9 & 21.3 & 10.3 \\
\hline 13 & 10.2 & 22.6 & 11.0 & 48 & 10.5 & 23.8 & 9.6 & 83 & 10.0 & 23.0 & 11.0 \\
\hline 14 & 10.9 & 25.0 & 11.4 & 49 & 10.2 & 22.1 & 10.3 & 84 & 10.2 & 23.2 & 10.2 \\
\hline 15 & 10.3 & 23.4 & 10.5 & 50 & 11.3 & 26.0 & 11.9 & 85 & 8.4 & 17.3 & 11.0 \\
\hline 16 & 10.2 & 23.0 & 10.5 & 51 & 9.6 & 22.5 & 10.8 & 86 & 10.0 & 21.3 & 10.8 \\
\hline 17 & 10.0 & 24.6 & 10.6 & 52 & 10.1 & 24.7 & 11.0 & 87 & 10.2 & 23.2 & 11.1 \\
\hline 18 & 10.2 & 23.4 & 11.1 & 53 & 10.0 & 22.2 & 11.0 & 88 & 10.2 & 21.9 & 10.6 \\
\hline 19 & 10.0 & 21.5 & 11.0 & 54 & 9.5 & 22.0 & 10.9 & 89 & 10.5 & 24.8 & 10.9 \\
\hline 20 & 10.2 & 22.5 & 11.6 & 55 & 10.3 & 23.8 & 12.3 & 90 & 10.1 & 22.0 & 10.9 \\
\hline 21 & 9.6 & 21.9 & 11.3 & 56 & 9.8 & 21.0 & 11.4 & 91 & 10.3 & 23.0 & 11.4 \\
\hline 22 & 10.6 & 23.1 & 11.7 & 57 & 10.4 & 23.0 & 10.0 & 92 & 10.1 & 22.6 & 10.4 \\
\hline 23 & 10.5 & 23.8 & 10.6 & 58 & 10.0 & 22.2 & 11.0 & 93 & 11.1 & 23.8 & 10.2 \\
\hline 24 & 10.6 & 23.7 & 11.4 & 59 & 10.9 & 23.4 & 10.7 & 94 & 10.1 & 24.4 & 9.7 \\
\hline 25 & 10.3 & 22.2 & 10.7 & 60 & 10.2 & 22.2 & 10.5 & 95 & 10.8 & 23.5 & 10.7 \\
\hline 26 & 10.2 & 22.7 & 11.0 & 61 & 9.9 & 20.6 & 10.6 & 96 & 10.5 & 23.1 & 10.0 \\
\hline 27 & 10.0 & 24.0 & 10.4 & 62 & 10.3 & 23.8 & 11.1 & 97 & 10.5 & 24.0 & 10.2 \\
\hline 28 & 10.0 & 22.3 & 11.3 & 63 & 10.5 & 26.8 & 11.0 & 98 & 10.6 & 24.0 & 11.6 \\
\hline 29 & 10.1 & 21.6 & 10.7 & 64 & 9.6 & 19.9 & 10.2 & 99 & 10.0 & 22.0 & 9.9 \\
\hline 30 & 10.9 & 23.6 & 11.7 & 65 & 11.2 & 24.8 & 11.0 & 100 & 10.2 & 22.1 & \\
\hline 31 & 10.0 & 22.0 & 11.0 & 66 & 11.0 & 25.0 & 11.0 & & & & \\
\hline 32 & 10.2 & 24.5 & 10.9 & 67 & 9.8 & 21.2 & 11.2 & Average. & 10.22 & 22.86 & 10.84 \\
\hline 33 & 10.1 & 22.0 & 10.7 & 68 & 9.8 & 21.9 & 11.0 & Greatest. & 11.3 & 26.8 & 12.3 \\
\hline 34 & 10.3 & 23.2 & 11.6 & 69 & 10.2 & 21.4 & 10.1 & Least... & 8.4 & 17.3 & 9.6 \\
\hline 35 & 11.1 & 23.8 & 11.5 & 70 & 9.8 & 21.2 & 10.1 & & & & \\
\hline
\end{tabular}

This colony was thriving in May 1916.

In July 1917 we found 2 adults of the second generation as well as a large number of young individuals.

In January 1919 this colony was again examined and 100 adult specimens of the second generation were secured, measurements of which are given in table 10 and photographs of them on plates 28 and 29. 
The Loggerhead Key Colony M.

In May 1916 we planted 300 tips taken from Colony F, representing the first generation of Florida-grown Cerion viaregis of the 1914 planting. This colony was placed a little south of the entrance stake to Colony E, on the inner edge of the outer sand dune, which is covered by a mixed growth of Uniola paniculata and Sporobolus virginicus with a few bay cedars and small specimens of Tournefortia. The place is marked by a stake and a tag bearing the legend "Cerions, 1916, M."

In July 1917 we gathered, measured, and photographed 26 full-grown individuals of this colony (table 11); 30 adult and 7 almost adult from Colony $\mathbf{F}$ were added to the colony on this date.

TABLE No. 11.-Measurements of the first generation of Florida-grown Cerion viaregis Loggerhead Key Colony $M$.

\begin{tabular}{|c|c|c|c|c|c|c|c|c|c|c|c|}
\hline \multirow{2}{*}{$\begin{array}{c}\text { Serial } \\
\text { No. }\end{array}$} & \multirow{2}{*}{$\begin{array}{l}\text { No. of } \\
\text { whorls. }\end{array}$} & \multicolumn{2}{|c|}{$\begin{array}{l}\text { Measurements } \\
\text { of shells. }\end{array}$} & \multirow{2}{*}{$\begin{array}{c}\text { Serial } \\
\text { No. }\end{array}$} & \multirow{2}{*}{$\begin{array}{l}\text { No. of } \\
\text { whorls. }\end{array}$} & \multicolumn{2}{|c|}{$\begin{array}{l}\text { Measurements } \\
\text { of shells. }\end{array}$} & \multirow{2}{*}{$\begin{array}{l}\text { Serial } \\
\text { No. }\end{array}$} & \multirow{2}{*}{$\begin{array}{l}\text { No. of } \\
\text { whorls. }\end{array}$} & \multicolumn{2}{|c|}{$\begin{array}{l}\text { Measurements } \\
\text { of shells. }\end{array}$} \\
\hline & & Alt. & Diam. & & & Alt. & Diam. & & & Alt. & Diam. \\
\hline 1 & 10.2 & $\begin{array}{c}m m . \\
23.0\end{array}$ & $\begin{array}{c}m m . \\
12.0\end{array}$ & 11 & 9.7 & $\begin{array}{l}m m . \\
21.2\end{array}$ & $\begin{array}{c}m m . \\
\mathbf{1 0 . 9}\end{array}$ & 21 & 10.1 & $\begin{array}{c}m m . \\
23.1\end{array}$ & $\begin{array}{l}m m . \\
13.0\end{array}$ \\
\hline 2 & 10.2 & 22.0 & 11.5 & 12 & 10.8 & 23.8 & 12.0 & 22 & 9.7 & 21.2 & 12.0 \\
\hline 3 & 10.5 & 24.0 & 11.4 & 13 & 10.9 & 24.5 & 11.0 & 23 & 10.2 & 22.3 & 11.4 \\
\hline 4 & 10.4 & 23.2 & 11.4 & 14 & 10.1 & 22.7 & 11.7 & 24 & 9.4 & 20.0 & 11.2 \\
\hline 5 & 10.0 & 23.8 & 12.1 & 15 & 10.2 & 22.0 & 12.0 & 25 & 9.6 & 21.0 & 11.3 \\
\hline 6 & 10.1 & 22.4 & 11.5 & 16 & 10.2 & 24.5 & 13.0 & 26 & 9.8 & 21.2 & 11.0 \\
\hline 7 & 9.5 & 20.1 & 11.8 & 17 & 10.2 & 24.1 & 11.5 & & & & \\
\hline 8 & 10.2 & 23.6 & 12.4 & 18 & 10.5 & 21.7 & 12.0 & Average. & 10.14 & 22.63 & 11.71 \\
\hline 9 & 10.0 & 22.7 & 11.9 & 19 & 10.2 & 23.5 & 11.6 & Greatest. & 10.9 & 24.5 & 13.0 \\
\hline 10 & 10.8 & 24.1 & 11.4 & 20 & 10.2 & 22.8 & 11.5 & Least. . . & 9.4 & 20.0 & 10.9 \\
\hline
\end{tabular}

In June 1919 we collected 100 adults and 35 tips of the second generation of Cerion viaregis. The adults were photographed and measured. The photographs are shown on plates 30 and 31, while the measurements are given in table 12. The whole lot was planted as Colony P.

\section{The Loggerhead Key Colony P.}

This colony, when planted in January 1919, consisted of 100 adult and 35 tips of the second generation Florida-grown Cerion viaregis taken from Colony $K$. It is about 60 feet northwest of the entrance stake to Colony $\mathrm{E}$ on the east side, a little west of the line between the entrance stake and the light-house. The coarse calcareous sandy ground is covered by a scattered growth of Sporobolus virginicus and Uniola paniculata and fringed with bay cedars. The place is marked by a short stake bearing a tag with the legend "Cerions, 1919, P."

\section{The Loggerhead Key Colony Q.}

Colony Q consists of 100 adult and 5 tips of Cerion viaregis from Colony M, second generation Florida-grown individuals. It is on the outer dune on the east side, about 200 feet north of the entrance stake 
to Colony E. The ground here is covered by a scattered growth of Uniola paniculata and Sporobolus virginicus. The place is marked by a short stake bearing a tag with the legend "Cerions, 1919, Q."

TABLE No. 12.-Measurements of the second generation of Florida-grown Cerion viaregis from Loggerhead Key Colony $M$.

\begin{tabular}{|c|c|c|c|c|c|c|c|c|c|c|c|}
\hline \multirow{2}{*}{$\begin{array}{c}\text { Serial } \\
\text { No. }\end{array}$} & \multirow{2}{*}{$\begin{array}{l}\text { No. of } \\
\text { whorls. }\end{array}$} & \multicolumn{2}{|c|}{$\begin{array}{l}\text { Measurements } \\
\text { of shells. }\end{array}$} & \multirow{2}{*}{$\begin{array}{l}\text { Serial } \\
\text { No. }\end{array}$} & \multirow{2}{*}{$\begin{array}{l}\text { No. of } \\
\text { whorls. }\end{array}$} & \multicolumn{2}{|c|}{$\begin{array}{l}\text { Measurements } \\
\text { of shells. }\end{array}$} & \multirow{2}{*}{$\begin{array}{l}\text { Serial } \\
\text { No. }\end{array}$} & \multirow{2}{*}{$\begin{array}{c}\text { No. of } \\
\text { whorls. }\end{array}$} & \multicolumn{2}{|c|}{$\begin{array}{l}\text { Measurements } \\
\text { of shells. }\end{array}$} \\
\hline & & Alt. & Diam. & & & Alt. & Diam. & & & Alt. & Diam. \\
\hline 1 & 11.1 & $\begin{array}{l}m m . \\
25.5\end{array}$ & $\begin{array}{c}m m . \\
10.8\end{array}$ & 36 & 10.3 & $\begin{array}{l}m m . \\
23.3\end{array}$ & $\begin{array}{c}m m . \\
10.3\end{array}$ & 71 & 10.6 & $\begin{array}{c}m m . \\
25.2\end{array}$ & $\begin{array}{c}m m . \\
11.4\end{array}$ \\
\hline 2 & 10.2 & 22.0 & 10.6 & 37 & 11.3 & 25.4 & 12.3 & 72 & 10.0 & 24.3 & 11.6 \\
\hline 3 & 10.0 & 22.3 & 10.4 & 38 & 10.2 & 23.8 & 11.1 & 73 & 11.1 & 22.7 & 10.8 \\
\hline 4 & 10.2 & 22.0 & 10.0 & 39 & 10.4 & 22.8 & 11.3 & 74 & 10.4 & 23.5 & 10.7 \\
\hline 5 & 11.3 & 24.5 & 9.8 & 40 & 10.3 & 25.0 & 11.0 & 75 & 10.5 & 25.9 & 10.6 \\
\hline 6 & 10.5 & 24.7 & 11.2 & 41 & 10.4 & 23.0 & 10.3 & 76 & 10.4 & 24.8 & 12.0 \\
\hline 7 & 9.4 & 20.7 & 10.2 & 42 & 10.7 & 24.2 & 11.0 & 77 & 10.0 & 21.3 & 10.8 \\
\hline 8 & 10.0 & 21.8 & 9.3 & 43 & 10.5 & 22.7 & 10.2 & 78 & 10.6 & 22.5 & 10.3 \\
\hline 9 & 10.5 & 23.7 & 9.7 & 44 & 10.3 & 22.5 & 10.6 & 79 & 9.6 & 21.3 & 9.8 \\
\hline 10 & 10.2 & 21.8 & 10.3 & 45 & 10.9 & 24.9 & 12.2 & 80 & 10.1 & 21.4 & 12.0 \\
\hline 11 & 10.9 & 24.6 & 10.2 & 46 & 9.8 & 20.5 & 10.3 & 81 & 10.1 & 25.1 & 11.5 \\
\hline 12 & 10.5 & 23.9 & 10.4 & 47 & 10.8 & 23.8 & 10.7 & 82 & 10.0 & 23.9 & 11.8 \\
\hline 13 & 10.2 & 23.6 & 11.0 & 48 & 10.8 & 23.3 & 12.1 & 83 & 9.9 & 21.2 & 10.3 \\
\hline 14 & 10.1 & 21.8 & 10.3 & 49 & 9.7 & 20.9 & 9.6 & 84 & 9.2 & 19.4 & 9.7 \\
\hline 15 & 10.3 & 22.7 & 9.8 & 50 & 10.2 & 23.0 & 10.6 & 85 & 10.6 & 24.5 & 10.6 \\
\hline 16 & 10.2 & 24.2 & 10.7 & 51 & 10.3 & 23.8 & 10.7 & 86 & 9.3 & 21.8 & 10.2 \\
\hline 17 & 10.0 & 20.8 & 10.3 & 52 & 10.6 & 22.2 & 10.4 & 87 & 10.6 & 24.7 & 10.5 \\
\hline 18 & 10.4 & 23.7 & 10.5 & 53 & 10.2 & 23.2 & 10.0 & 88 & 10.1 & 21.8 & 12.0 \\
\hline 19 & 10.3 & 22.1 & 10.0 & 54 & 10.6 & 24.8 & 11.8 & 89 & 9.7 & 21.1 & 10.0 \\
\hline 20 & 10.1 & 23.0 & 9.9 & 55 & 10.0 & 23.7 & 11.1 & 90 & 9.9 & 19.9 & 10.6 \\
\hline 21 & 10.7 & 24.3 & 10.0 & 56 & 11.0 & 26.0 & 11.8 & 91 & 10.5 & 24.0 & 10.5 \\
\hline 22 & 9.8 & 22.6 & 11.1 & 57 & 10.5 & 25.3 & 10.3 & 92 & 10.3 & 22.5 & 11.2 \\
\hline 23 & 10.3 & 23.9 & 11.1 & 58 & 10.3 & 24.0 & 11.9 & 93 & 11.0 & 26.3 & 11.0 \\
\hline 24 & 10.5 & 25.1 & 11.1 & 59 & 11.2 & 24.9 & 10.7 & 94 & 10.3 & 23.0 & 10.8 \\
\hline 25 & 10.6 & 23.5 & 10.3 & 60 & 10.3 & 22.1 & 10.6 & 95 & 10.1 & 22.3 & 11.0 \\
\hline 26 & 10.4 & 23.0 & 10.4 & 61 & 10.8 & 25.5 & 10.3 & 96 & 10.2 & 23.0 & 10.2 \\
\hline 27 & 10.5 & 23.4 & 10.4 & 62 & 10.7 & 24.6 & 11.5 & 97 & 10.1 & 23.7 & 10.8 \\
\hline 28 & 11.3 & 28.1 & 12.1 & 63 & 10.1 & 22.9 & 9.8 & 98 & 10.1 & 23.0 & 11.2 \\
\hline 29 & 10.3 & 22.1 & 10.4 & 64 & 10.6 & 22.9 & 10.9 & 99 & 10.3 & 23.6 & 11.4 \\
\hline 30 & 10.1 & 23.0 & 11.0 & 65 & 11.1 & 27.3 & 11.6 & 100 & 9.3 & 21.0 & 9.9 \\
\hline 31 & 10.3 & 22.5 & 10.6 & 66 & 10.4 & 24.2 & 11.2 & & & & \\
\hline 32 & 10.2 & 20.2 & 10.2 & 67 & 10.6 & 24.4 & 11.8 & Average. & 10.33 & 23.24 & 10.73 \\
\hline 33 & 10.1 & 23.1 & 11.0 & 68 & 11.0 & 25.2 & 10.5 & Greatest. & 11.3 & 28.1 & 12.3 \\
\hline 34 & 10.1 & 20.2 & 10.2 & 69 & 10.3 & 23.3 & 10.8 & Least... & 9.2 & 19.4 & 9.3 \\
\hline 35 & 10.0 & 21.2 & 10.5 & 70 & 9.9 & 21.0 & 10.7 & & & & \\
\hline
\end{tabular}

The Loggerhead Key Colony R.

This consists of 200 of the first generation of Florida-grown Cerion viaregis from Colony $\mathrm{F}$, and is planted 140 feet west of Colony $\mathrm{M}$, in a small meadow supporting a scattered growth of Uniola paniculata and Sporobolus virginicus. The place is marked by a short stake bearing a tag with the legend "Cerions, 1919, R." 


\section{DISCUSSION OF DATA.}

\section{First Generation of Florida-grown Cerion viaregis.}

In reviewing the pictures of all the first-generation specimens of Florida-grown Cerion viaregis and comparing them with the check series of specimens found on Andros Island, Bahamas, one is led to the conclusion that, as far as general shape and sculpture are concerned, little or no new variations have appeared in the Florida-grown specimens. Whatever variation occurs in the Florida specimens is also to be found in the check series from Andros Island. An analysis of the measurements of the first generation of all the Florida-grown specimens gives the results shown in table 13.

TABLE No. 13.-First generation Florida-grown Cerion viaregis.

\begin{tabular}{|c|c|c|c|c|}
\hline Colony. & $\begin{array}{l}\text { No. of } \\
\text { whorls. }\end{array}$ & Altitude. & $\begin{array}{l}\text { Greater } \\
\text { diameter. }\end{array}$ & $\begin{array}{c}\text { No. of } \\
\text { specimens. }\end{array}$ \\
\hline 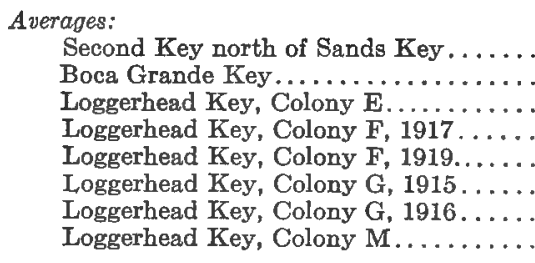 & $\begin{array}{l}10.03 \\
10.31 \\
10.05 \\
10.15 \\
10.20 \\
10.21 \\
10.20 \\
10.14\end{array}$ & $\begin{array}{l}m m . \\
22.82 \\
23.57 \\
22.47 \\
22.53 \\
22.59 \\
22.73 \\
23.39 \\
22.63\end{array}$ & $\begin{array}{l}m m . \\
10.40 \\
10.46 \\
10.02 \\
11.68 \\
10.60 \\
10.37 \\
10.70 \\
11.71\end{array}$ & $\begin{array}{r}76 \\
107 \\
250 \\
30 \\
100 \\
49 \\
78 \\
26\end{array}$ \\
\hline $\begin{array}{c}\text { Average of all Florida-grown first } \\
\text { generation } \ldots \ldots \ldots \ldots \ldots \ldots \ldots \\
\text { Average of check series................ }\end{array}$ & $\begin{array}{l}10.16 \\
10.08\end{array}$ & $\begin{array}{l}22.84 \\
22.56\end{array}$ & $\begin{array}{l}10.74 \\
11.13\end{array}$ & 716 \\
\hline 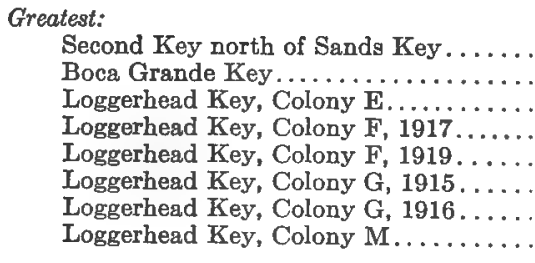 & $\begin{array}{l}11.0 \\
11.2 \\
12.0 \\
10.6 \\
11.5 \\
11.2 \\
11.2 \\
10.9\end{array}$ & $\begin{array}{l}25.8 \\
27.1 \\
27.9 \\
24.2 \\
27.7 \\
26.0 \\
27.0 \\
24.5\end{array}$ & $\begin{array}{l}11.4 \\
11.6 \\
11.4 \\
12.5 \\
12.0 \\
11.7 \\
11.9 \\
13.0\end{array}$ & \\
\hline $\begin{array}{l}\text { Greatest of all Florida-grown first } \\
\text { generation } \ldots \ldots \ldots \ldots \ldots \ldots \ldots \\
\text { Greatest of check series............. }\end{array}$ & $\begin{array}{l}12.0 \\
11.0\end{array}$ & $\begin{array}{l}27.9 \\
27.0\end{array}$ & $\begin{array}{l}13.0 \\
12.7\end{array}$ & \\
\hline 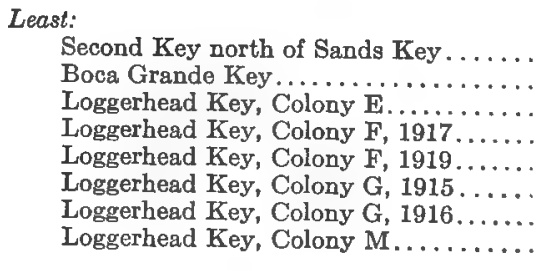 & $\begin{array}{l}8.9 \\
9.5 \\
8.9 \\
9.4 \\
9.5 \\
9.2 \\
9.3 \\
9.4\end{array}$ & $\begin{array}{l}19.2 \\
20.2 \\
18.7 \\
20.0 \\
19.7 \\
20.0 \\
20.9 \\
20.0\end{array}$ & $\begin{array}{r}9.5 \\
9.0 \\
8.8 \\
10.5 \\
9.4 \\
9.5 \\
10.0 \\
10.9\end{array}$ & \\
\hline 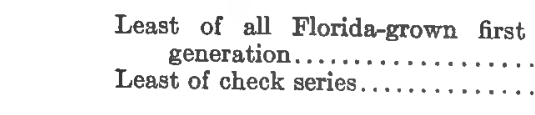 & $\begin{array}{l}8.9 \\
9.1\end{array}$ & $\begin{array}{l}18.7 \\
19.0\end{array}$ & $\begin{array}{l}8.8 \\
9.0\end{array}$ & \\
\hline
\end{tabular}


Table 13 indicates merely that we have in this Florida-grown material a very slightly larger range of variation, but no difference in type. The largest number of whorls observed in any member of this generation is $12 \mathrm{~mm}$. and the least $8.9 \mathrm{~mm}$. In the check series we find 11 $\mathrm{mm}$. and $9.1 \mathrm{~mm}$. The largest altitude observed in this generation was $27.9 \mathrm{~mm}$. and the smallest $18.7 \mathrm{~mm}$., while in the check series the largest was $27 \mathrm{~mm}$. and the smallest $19 \mathrm{~mm}$. The greater diameter of our Florida-grown material was $13 \mathrm{~mm}$. and the least $8.8 \mathrm{~mm}$., whereas in the check series we obtained $12.7 \mathrm{~mm}$. for the largest measurement and $9 \mathrm{~mm}$. for the least. A comparison of the average measurements of all the Florida-grown first generation material with the average measurement of the check series presents the following:

Number of whorls, $\mathbf{1 0 . 1 6}$ for the Florida-grown specimens and 10.08 for the check series. Altitude, $22.84 \mathrm{~mm}$. for the Florida-grown generation and 22.56 for the check series.

Greatest diameter, $10.74 \mathrm{~mm}$. for the Florida-grown specimens against $11.13 \mathrm{~mm}$. for the check series.

The trifling discrepancies in measurements, therefore, as well as sculpture, enable us to say that the amount of increased variation noted in the Florida-grown material is practically nil. It is not at all unreasonable to believe that if an equally large number of Bahama shells had been subjected to analysis parallel results might have been obtained.

\section{Second Generation of Florida-grown Cerion viaregts.}

Of the second generation of Florida-grown Cerion viaregis, we have now had 208 specimens from three different colonies. Table 14 gives the measurable data presented by these and makes a comparison with the check series from Andros Island, Bahamas.

This discloses that the second generation of Florida-grown material of Cerion viaregis is also slightly more variable than the check series of Bahama material, for here we find that the greatest number of whorls is $11.3 \mathrm{~mm}$., while in the check series it is $11 \mathrm{~mm}$. The altitude measurement is $28.1 \mathrm{~mm}$. against $27 \mathrm{~mm}$. of the check series, while the average greater diameter is a little less than that of the check series, namely, $12.3 \mathrm{~mm}$. against $12.7 \mathrm{~mm}$. The least number of whorls observed in any of the members of the second generation of Florida-grown Cerion viaregis is $8.4 \mathrm{~mm}$., while in the check series the least observed was $9.1 \mathrm{~mm}$. The least altitude of the Florida-grown specimens is $17.3 \mathrm{~mm}$. against $19 \mathrm{~mm}$. of the check series, and the least diameter is $9.3 \mathrm{~mm}$. against $9 \mathrm{~mm}$. of the check series.

Table 15 shows that in the number of whorls the second Floridagrown generation presents only a negligible increase over the Bahaman check series and the first Florida generation; it likewise shows an average altitude measurement a little higher than the other two, but an average diameter measurement halfway between the check series and 
EXPERIMENTS IN THE BREEDING OF CERIONS.

TABLE No. 14.-Second generation of Florida-grown Cerion viaregis.

\begin{tabular}{|c|c|c|c|c|}
\hline Colony. & $\begin{array}{l}\text { No. of } \\
\text { whorls. }\end{array}$ & Altitude. & $\begin{array}{c}\text { Greater } \\
\text { diameter. }\end{array}$ & $\begin{array}{c}\text { No. of } \\
\text { specimens. }\end{array}$ \\
\hline $\begin{array}{l}\text { Averages: } \\
\quad \text { Second Key north of Sands Key } \ldots \ldots \ldots \ldots \\
\quad \text { Loggerhead Key, Colony } \mathrm{K} . \ldots \ldots \ldots \ldots \ldots \\
\quad \text { Loggerhead Key, Colony } M \ldots \ldots \ldots \ldots \ldots\end{array}$ & $\begin{array}{l}10.21 \\
10.22 \\
10.33\end{array}$ & $\begin{array}{l}m m . \\
22.95 \\
22.86 \\
23.24\end{array}$ & $\begin{array}{l}m m . \\
10.87 \\
10.84 \\
10.73\end{array}$ & $\begin{array}{r}8 \\
100 \\
100\end{array}$ \\
\hline 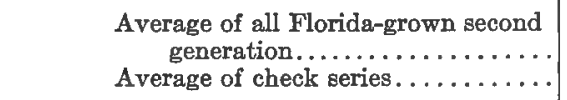 & $\begin{array}{l}10.25 \\
10.08\end{array}$ & $\begin{array}{l}23.01 \\
22.56\end{array}$ & $\begin{array}{l}10.81 \\
11.13\end{array}$ & 208 \\
\hline 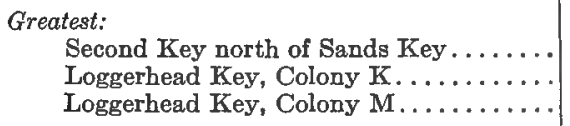 & $\begin{array}{l}11.1 \\
11.3 \\
11.3\end{array}$ & $\begin{array}{l}24.2 \\
26.8 \\
28.1\end{array}$ & $\begin{array}{l}11.3 \\
12.3 \\
12.3\end{array}$ & \\
\hline $\begin{array}{l}\text { Greatest of all Florida-grown second } \\
\text { generation....................... } \\
\text { Greatest of check series.......... }\end{array}$ & $\begin{array}{l}11.3 \\
11.0\end{array}$ & $\begin{array}{l}28.1 \\
27.0\end{array}$ & $\begin{array}{l}12.3 \\
12.7\end{array}$ & \\
\hline $\begin{array}{l}\text { Least: } \\
\quad \text { Second Key north of Sands Key } \ldots \ldots \ldots \\
\quad \text { Loggerhead Key, Colony K............... } \\
\quad \text { Loggerhead Key, Colony M.......... }\end{array}$ & $\begin{array}{l}9.6 \\
8.4 \\
9.2\end{array}$ & $\begin{array}{l}21.0 \\
17.3 \\
19.4\end{array}$ & $\begin{array}{r}10.2 \\
9.6 \\
9.3\end{array}$ & \\
\hline $\begin{array}{l}\text { Least of all Florida-grown second } \\
\text { generation...................... } \\
\text { Least of check series............. }\end{array}$ & $\begin{array}{l}8.4 \\
9.1\end{array}$ & $\begin{array}{l}17.3 \\
19.0\end{array}$ & $\begin{array}{l}9.3 \\
9.0\end{array}$ & \\
\hline
\end{tabular}

TABLE No. 15.-Comparison between check series of Cevion viaregis and first and second generation of Florida-grown specimens.

\begin{tabular}{|c|c|c|c|}
\hline & $\begin{array}{l}\text { No. of } \\
\text { whorls. }\end{array}$ & Altitude. & $\begin{array}{c}\text { Greater } \\
\text { diameter. }\end{array}$ \\
\hline Averages: & & $m m$ & $m m$. \\
\hline Check series $\ldots \ldots \ldots \ldots \ldots \ldots \ldots \ldots \ldots \ldots, \ldots$ & 10.08 & 22.56 & 11.13 \\
\hline First generation Florida-grown specimens........ & 10.16 & 22.84 & 10.74 \\
\hline Second generation Florida-grown specimens... & 10.25 & 23.01 & 10.81 \\
\hline \multicolumn{4}{|l|}{ Greatest: } \\
\hline Check series $, \ldots \ldots, \ldots, \ldots, \ldots, \ldots, \ldots, \ldots \ldots$ & 11.0 & 27.0 & 12.7 \\
\hline First generation Florida-grown specimens............ & 12.0 & 27.9 & 13.0 \\
\hline Second generation Florida-grown specimens............. & 11.3 & 28.1 & 12.3 \\
\hline \multicolumn{4}{|l|}{ Least: } \\
\hline 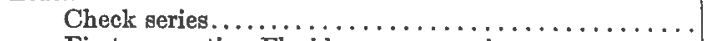 & 9.1 & & \\
\hline First generation Florida-grown specimens.............. & 8.9 & 18.7 & 8.8 \\
\hline Second generation Florida-grown specimens............ & 8.4 & 17.3 & 9.3 \\
\hline
\end{tabular}

the first generation. The specimen having the greatest number of whorls in the second generation has less than the specimen having the greatest number of whorls in the first generation. In that respect it is nearer to the specimen having the greatest number of whorls in the check series, but the amount of variation there may again be said to be negligible. In altitude we find one specimen in the second genera- 
tion which exceeds by $1.2 \mathrm{~mm}$. any found in the check series or in the first generation. Cerions are fairly variable in measurements, as shown in our series, and this one large exceptional specimen does not really mean anything in this instance.

The greatest diameter presented by any specimen of the second generation is a little less than that presented by any member of the check series or the first generation. When it comes to the least measurement we find that in the number of whorls the second generation has given us a specimen with 8.4 whorls, which is less than that presented by any form of the check series or the first generation. In the altitude measurements, too, we find one specimen with $17.3 \mathrm{~mm}$., which is considerably less than the altitude of the two other groups, while in the measurement of the diameter the least diameter shown by any specimen of the second generation is slightly greater than that of the check series or the members of the first generation. However, it is perfectly safe to say that all the variations presented by the Florida-grown first and second generation specimens do not speak for any material change having taken place within this group. I feel perfectly confident that all the variations presented here are entirely within the range of Cerion viaregis as it occurs at Bastian Point. This, then, means that the changed environment to which we have subjected these organisms in transplanting them to Florida has not affected them in such a way as to produce such differences as one observes between the various colonies in the Bahamas. That is, that Cerion viaregis seems to be quite stable within its normal limits of variation and appears to adhere to these limits even when subjected to a decidedly changed environment.

\section{Cerion casablancar Bartsch.}

Of this species 100 specimens have been taken at random from a lot collected in the White House region on Andros. Figures of these are given upon plates 32-34. Their measurements are shown in table 16. These specimens are entered as Cat. No. 334723, U. S. N. M., and No. 13 is selected to serve as type.

The Colony on the First Ragged Key North of Sande Key.

On this key 500 specimens of Cerion casablancee were planted in June 1912, on a sandy ridge on the middle of the outside of the key. Here we have a fringing element of bay cedar to the seaward, as well as on the inner margin of the dune. The dune itself contains a sparse growth of Sporobolus virginicus, some Hymenocallis, and a very dense matting of Sesuvium portulacastrum.

On April 25, 1913, we found most of the planted specimens attached to the stems and leaves of the succulent Sesuvium; they seemed to be thriving in this new habitat. We also discovered 3 young shells having 1.3, 1.5 and 2 postnuclear whorls respectively. 
Table No. 16.-Check series of Cerion casablanca.

\begin{tabular}{|c|c|c|c|c|c|c|c|c|c|c|c|}
\hline \multirow{2}{*}{$\begin{array}{l}\text { Serial } \\
\text { No. }\end{array}$} & \multirow{2}{*}{$\begin{array}{l}\text { No. of } \\
\text { whorls. }\end{array}$} & \multicolumn{2}{|c|}{$\begin{array}{l}\text { Measurements } \\
\text { of shells. }\end{array}$} & \multirow{2}{*}{$\begin{array}{l}\text { Serial } \\
\text { No. }\end{array}$} & \multirow{2}{*}{$\begin{array}{l}\text { No. of } \\
\text { whorls. }\end{array}$} & \multicolumn{2}{|c|}{$\begin{array}{l}\text { Measurements } \\
\text { of shells. }\end{array}$} & \multirow{2}{*}{$\begin{array}{l}\text { Serial } \\
\text { No. }\end{array}$} & \multirow{2}{*}{$\begin{array}{l}\text { No. of } \\
\text { whorls. }\end{array}$} & \multicolumn{2}{|c|}{$\begin{array}{l}\text { Measurements } \\
\text { of shells. }\end{array}$} \\
\hline & & Alt. & Diam. & & & Alt. & Diam. & & & Alt. & Diam. \\
\hline 1 & 10.6 & $\begin{array}{l}m m . \\
24.1\end{array}$ & $\begin{array}{c}m m . \\
12.0\end{array}$ & 36 & 10.1 & $\begin{array}{c}m m . \\
24.9\end{array}$ & $\begin{array}{l}m m . \\
13.8\end{array}$ & 71 & 11.0 & $\begin{array}{l}m m . \\
27.1\end{array}$ & $m m$. \\
\hline 2 & 10.4 & 26.9 & 12.9 & 37 & 12.1 & 32.9 & 13.8 & 72 & 10.4 & 26.2 & $\begin{array}{l}13.5 \\
12.6\end{array}$ \\
\hline 3 & 11.0 & 26.7 & 11.3 & 38 & 10.4 & 26.2 & 13.2 & 73 & 11.0 & 25.8 & 14.6 \\
\hline 4 & 11.3 & 28.3 & 12.8 & 39 & 11.0 & 28.3 & 14.5 & 74 & 11.1 & 26.9 & 12.7 \\
\hline 5 & 10.4 & 24.0 & 11.0 & 40 & 10.8 & 26.6 & 14.8 & 75 & 10.6 & 27.6 & 13.6 \\
\hline 6 & 10.9 & 26.0 & 12.6 & 41 & 11.5 & 29.0 & 14.3 & 76 & 10.9 & 26.2 & 14.1 \\
\hline 7 & 10.9 & 26.9 & 12.5 & 42 & 10.1 & 25.2 & 13.6 & 77 & 10.9 & 25.3 & 14.0 \\
\hline 8 & 10.0 & 25.0 & 11.8 & 43 & 11.9 & 30.0 & 13.2 & 78 & 11.3 & 28.0 & 14.0 \\
\hline 9 & 10.6 & 25.5 & 11.5 & 44 & 11.2 & 27.0 & 13.9 & 79 & 11.1 & 27.5 & 14.3 \\
\hline 10 & 10.4 & 26.8 & 12.6 & 45 & 10.8 & 26.5 & 11.8 & 80 & 10.5 & 24.6 & 13.9 \\
\hline 11 & 10.9 & 25.3 & 12.8 & 46 & 10.1 & 24.9 & 12.9 & 81 & 10.9 & 25.5 & 15.0 \\
\hline 12 & 11.2 & 29.2 & 13.4 & 47 & 10.9 & 27.2 & 14.3 & 82 & 11.1 & 27.3 & 13.1 \\
\hline 13 & 10.7 & 27.6 & 13.7 & 48 & 10.9 & 26.4 & 13.5 & 83 & 10.6 & 26.3 & 14.2 \\
\hline 14 & 10.6 & 26.0 & 13.2 & 49 & 11.1 & 29.4 & 13.6 & 84 & 11.0 & 26.1 & 12.7 \\
\hline 15 & 11.0 & 27.3 & 14.4 & 50 & 11.1 & 27.1 & 14.4 & 85 & 10.9 & 25.1 & 14.1 \\
\hline 16 & 11.1 & 29.4 & 14.5 & 51 & 10.7 & 26.5 & 14.0 & 86 & 10.1 & 26.0 & 13.2 \\
\hline 17 & 11.6 & 30.3 & 13.8 & 52 & 10.5 & 25.1 & 13.5 & 87 & 10.5 & 25.8 & 15.1 \\
\hline 18 & 11.2 & 31.4 & 14.8 & 53 & 10.7 & 28.5 & 14.6 & 88 & 10.5 & 26.8 & 14.5 \\
\hline 19 & 10.8 & 28.0 & 13.2 & 54 & 10.2 & 24.2 & 13.2 & 89 & 11.1 & 27.0 & 14.4 \\
\hline 20 & 12.1 & 31.6 & 13.5 & 55 & 10.8 & 27.3 & 13.4 & 90 & 11.4 & 26.0 & 13.7 \\
\hline 21 & 12.0 & 31.5 & 15.0 & 56 & 10.6 & 28.2 & 15.1 & 91 & 10.6 & 25.3 & 13.5 \\
\hline 22 & 10.9 & 26.7 & 13.2 & 57 & 10.6 & 26.0 & 15.6 & 92 & 10.8 & 26.5 & 13.5 \\
\hline 23 & 11.5 & 27.7 & 14.2 & 58 & 10.6 & 25.2 & 13.1 & 93 & 10.8 & 24.8 & 14.0 \\
\hline 24 & 11.1 & 25.8 & 15.2 & 59 & 11.4 & 28.2 & 14.0 & 94 & 10.4 & 25.7 & 14.4 \\
\hline 25 & 11.5 & 29.2 & 13.5 & 60 & 10.5 & 25.8 & 13.7 & 95 & 10.4 & 24.7 & 13.7 \\
\hline 26 & 11.5 & 29.2 & 14.5 & 61 & 11.2 & 28.5 & 14.0 & 96 & 11.4 & 30.0 & 14.0 \\
\hline 27 & 11.2 & 29.0 & 14.0 & 62 & 10.7 & 28.3 & 14.3 & 97 & 10.9 & 25.4 & 15.0 \\
\hline 28 & 10.9 & 27.7 & 13.1 & 63 & 11.9 & 26.6 & 14.5 & 98 & 11.5 & 31.6 & 14.5 \\
\hline 29 & 11.8 & 30.9 & 14.3 & 64 & 10.5 & 26.7 & 13.5 & 99 & 11.0 & 27.9 & 15.0 \\
\hline 30 & 11.4 & 28.9 & 13.0 & 65 & 10.6 & 26.3 & 15.5 & 100 & 10.8 & 28.6 & 15.3 \\
\hline 31 & 11.3 & 29.5 & 14.3 & 66 & 11.5 & 29.4 & 13.2 & & & & \\
\hline 32 & 11.1 & 27.6 & 13.2 & 67 & 10.5 & 26.0 & 14.2 & Average. & 10.92 & 27.19 & 13.7 \\
\hline 33 & 11.0 & 29.8 & 14.4 & 68 & 10.8 & 26.3 & 13.9 & Greatest. & 12.1 & 32.9 & 15.6 \\
\hline 34 & 11.1 & 28.7 & 12.8 & 69 & 10.7 & 26.4 & 14.2 & Least. . . & 10.0 & 24.0 & 11.0 \\
\hline 35 & 10.2 & 25.2 & 14.0 & 70 & 11.4 & 27.0 & 11.9 & & & & \\
\hline
\end{tabular}

In 1914 a house was built in the midst of our plantation, but this has not materially affected this planting; 50 young secured in April 1914 were taken to Sands Key to start a new colony.

In June 1915 we secured 23 adult specimens of the first generation of Florida-grown shells, which we measured and photographed, together with 45 young, varying from a quarter-grown to almost adult, on the same sand ridge upon which the original planting was made, but about 50 feet to the north of it. Later we discovered 13 additional adults of the first generation, which we likewise marked and added to this planting. The 23 specimens photographed are represented on plate 35 and their measurements are given in table 17.

In 1919 we found that the key had been transferred to a new purchaser, who was cutting off the bushes. Most of the ground containing our second plantation had been completely burned over and we were 
TABLE No. 17.-Measurements of the first generation of Florida-grown Cerion casablanca from the first Ragged Key north of Sands Key.

\begin{tabular}{|c|c|c|c|c|c|c|c|c|c|c|c|}
\hline \multirow{2}{*}{$\begin{array}{c}\text { Serial } \\
\text { No. }\end{array}$} & \multirow{2}{*}{$\begin{array}{l}\text { No. of } \\
\text { whorls. }\end{array}$} & \multicolumn{2}{|c|}{$\begin{array}{l}\text { Measurements } \\
\text { of shells. }\end{array}$} & \multirow{2}{*}{$\mid \begin{array}{c}\text { Serial } \\
\text { No. }\end{array}$} & \multirow{2}{*}{$\begin{array}{l}\text { No. of } \\
\text { whorls. }\end{array}$} & \multicolumn{2}{|c|}{$\begin{array}{l}\text { Measurements } \\
\text { of shells. }\end{array}$} & \multirow{2}{*}{$\begin{array}{l}\text { Serial } \\
\text { No. }\end{array}$} & \multirow{2}{*}{$\begin{array}{l}\text { No. of } \\
\text { whorls. }\end{array}$} & \multicolumn{2}{|c|}{$\begin{array}{l}\text { Measurements } \\
\text { of shells. }\end{array}$} \\
\hline & & Alt. & Diam. & & & Alt. & Diam. & & & Alt. & Diam. \\
\hline 1 & 10.0 & $\begin{array}{l}m m . \\
26.7\end{array}$ & $\begin{array}{l}m m . \\
13.8\end{array}$ & 10 & 10.7 & $\begin{array}{l}m m . \\
29.6\end{array}$ & $\begin{array}{l}m m . \\
14.0\end{array}$ & 19 & 10.1 & $\begin{array}{l}m m . \\
28.0\end{array}$ & $\begin{array}{l}m m . \\
13.0\end{array}$ \\
\hline 2 & 10.0 & 24.7 & 12.5 & 11 & 10.5 & 29.5 & 13.8 & 20 & 10.5 & 26.9 & 13.3 \\
\hline 3 & 11.0 & 25.2 & 14.0 & 12 & 10.9 & 29.3 & 13.3 & 21 & 10.1 & 27.0 & 12.9 \\
\hline 4 & 10.0 & 24.0 & 13.5 & 13 & 10.8 & 30.1 & 14.0 & 22 & 10.3 & 27.6 & 13.3 \\
\hline 5 & 10.8 & 27.4 & 12.6 & 14 & 10.3 & 28.9 & 13.9 & 23 & 10.0 & 26.2 & 12.5 \\
\hline 6 & 10.5 & 30.3 & 14.0 & 15 & 10.8 & 29.3 & 14.0 & & & & \\
\hline 7 & 10.1 & 31.0 & 13.9 & 16 & 10.7 & 29.0 & 14.2 & Average. & 10.45 & 28.31 & 14.1 \\
\hline 8 & 11.1 & 31.3 & 14.0 & 17 & 10.0 & 28.9 & 15.0 & Greatest. & 11.1 & 32.0 & 15.0 \\
\hline 9 & 10.9 & 32.0 & 14.0 & 18 & 10.2 & 28.1 & 14.2 & Least.... & 10.0 & 24.0 & 12.5 \\
\hline
\end{tabular}

able to find only 2 of the marked shells and 2 which belong to the second generation. These are numbers 24 and 25 of plate 35 . The original planting about the house escaped the burning, but we fear that the new buildings which are to be erected, as well as the human activities which are to be displayed upon this key, will probably exterminate this planting. The measurements of two specimens of the second Florida-grown generation are given in table 18.

\section{The Colony on Sands Ker.}

In April 1914 we planted 50 tips, varying in size from nepionic shells to half-grown individuals. These were placed in the middle of TABle No. 18. the first sand stretch south of the north end on the seaward side. The place is marked by a skinned, bleached, white tree, which forms a conspicuous landmark on the sea-side. There were two lesser dead trees on each side of the taller stump. The specimens were placed in a patch of grass near the base of the outer dead tree, which appeared to be a very favorable habitat.

In June 1915 we found only a single half-grown specimen, and since then not one has been discovered. Previous experience, however, would lead us to believe that it is possible that members of this little colony may still survive and in course of time may populate the region.

\section{The Colony on Indian Key.}

On June 1, 1912, we placed 500 specimens of Cerion casablance about the ruins of an old house on the bay side of the key. When we visited this planting on April 26, 1913, the Cerions were doing well, some of them having moved fully 60 feet from the place where they had been dropped. Most of those seen were on dead sticks, usually clustered in groups, though many were on the rank growth of Sesuvium portulacastrum which threatens to overrun the place. We found 20 of the planted 
specimens dead among the material gathered on this date, and we thought it possible that this might be due to the too luxuriant growth of Sesuvium, and therefore deemed it best to move the colony. We placed 225 living specimens near the southern part of the westerly one of two foundation walls north of the cistern, and marked the situation with a stake.

On April 22, 1914, this new colony was still in force, but we were unable to find any young individuals. The old planting was completely overrun with rank vegetation, even more rank than on the previous year; in fact it was impossible to determine if any specimens had survived.

In May 1916 the Cerions were doing well at both plantings. We gathered 18 adult living specimens of the first generation of Floridagrown individuals and 31 of those originally imported at the second planting. The Florida-grown individuals were measured and marked and placed about 5 feet east of the stone wall, which is a remnant of a house on the east end of the key, while we replanted the Bahama material a little west of the center of the second stone wall.

The original planting, which was completely swamped by a rank growth of vegetation during the past two years, seemed to have survived quite well. This year the drought was so great that the grass was dried up to a large extent. Even the cacti had a shriveled appearance

TABLE No. 19.-Measurements of the first generation of Florida-grown Cerion casablancee from Indian Key.

\begin{tabular}{|c|c|c|c|c|c|c|c|c|c|c|c|}
\hline \multirow{2}{*}{$\begin{array}{l}\text { Serial } \\
\text { No. }\end{array}$} & \multirow{2}{*}{$\begin{array}{l}\text { No. of } \\
\text { whorls. }\end{array}$} & \multicolumn{2}{|c|}{$\begin{array}{l}\text { Measurements } \\
\text { of shells. }\end{array}$} & \multirow{2}{*}{$\mid \begin{array}{c}\text { Serial } \\
\text { No. }\end{array}$} & \multirow{2}{*}{$\begin{array}{l}\text { No. of } \\
\text { whorls. }\end{array}$} & \multicolumn{2}{|c|}{$\begin{array}{l}\text { Measurements } \\
\text { of shells. }\end{array}$} & \multirow{2}{*}{$\begin{array}{l}\text { Serial } \\
\text { No. }\end{array}$} & \multirow{2}{*}{$\begin{array}{l}\text { No. of } \\
\text { whorls. }\end{array}$} & \multicolumn{2}{|c|}{$\begin{array}{l}\text { Measurements } \\
\text { of shells. }\end{array}$} \\
\hline & & Alt. & Diam. & & & Alt. & Diam. & & & Alt. & Diam. \\
\hline $\begin{array}{l}1 \\
2 \\
3 \\
4 \\
5\end{array}$ & $\begin{array}{l}10.8 \\
11.0 \\
10.6 \\
11.3 \\
10.2\end{array}$ & $\begin{array}{l}m m . \\
28.0 \\
31.0 \\
28.4 \\
29.0 \\
27.5\end{array}$ & $\begin{array}{l}m m . \\
12.7 \\
13.0 \\
13.0 \\
13.3 \\
12.2\end{array}$ & $\begin{array}{r}8 \\
9 \\
10 \\
11 \\
12\end{array}$ & $\begin{array}{r}10.2 \\
9.8 \\
10.6 \\
10.4 \\
10.2\end{array}$ & $\begin{array}{l}m m . \\
26.1 \\
28.4 \\
27.3 \\
26.0 \\
24.0\end{array}$ & $\begin{array}{c}m m . \\
12.9 \\
13.8 \\
12.3 \\
12.8 \\
13.0\end{array}$ & $\begin{array}{l}15 \\
16 \\
17 \\
18\end{array}$ & $\begin{array}{l}10.2 \\
10.2 \\
10.3 \\
11.0\end{array}$ & $\begin{array}{l}m m . \\
27.0 \\
27.0 \\
27.0 \\
29.0\end{array}$ & $\begin{array}{c}m m . \\
11.8 \\
13.5 \\
12.3 \\
12.3\end{array}$ \\
\hline 6 & 10.0 & 25.3 & 12.2 & 13 & 10.4 & 27.0 & 12.1 & Average & 10.5 & 27.45 & 12.72 \\
\hline 7 & 10.5 & 29.1 & 12.8 & 14 & 11.3 & 27.0 & 13.0 & $\begin{array}{l}\text { Greatest. } \\
\text { Least. . . }\end{array}$ & $\begin{array}{r}11.3 \\
9.8\end{array}$ & $\begin{array}{l}31.0 \\
24.0\end{array}$ & $\begin{array}{l}13.8 \\
11.8\end{array}$ \\
\hline
\end{tabular}

and this enabled us to discover 29 of the originally planted Cerions, 49 adult Florida-grown individuals, and 15 tips. We planted the Florida-grown individuals in one place at the inner edge of the grass, about 45 feet east and a little to the left of the stone wall, looking landward.

In 1917 and 1918 this colony was not visited.

On January 21, 1919, when we again visited Indian Key, the old plantation was completely swamped with a growth of Sesuvium, 
Uniola paniculata, and cacti. The planting in the interior was in even worse condition, for, in addition to the cacti and other rank vegetation, a complete invasion of huge agaves covered the territory and made it literally impossible to move about except where one actually cut a path through the bayonet-like agave leaves. We were therefore unable to secure any material of the second generation from this colony.

The Colony on Bahia Honda Key.

On June 2, 1912, we placed 500 specimens of Cerion casablancoe on the northeast side of the deep cut which runs parallel with the outer beach. The ground supported a scattered growth of palmetto and grass.

On April 22, 1913, the place was completely overrun with sand spurs, Cenchrus echinatus, in full fruit, which made a search for mollusks a trying task.

On April 23, 1914, we found 10 adult specimens and 3 nearly adult of the first generation of Florida-grown individuals. The measurements are shown in table 20 and the figures of the specimens are shown on plate 5 of the 1915 report.

On April 26, 1915, the colony was visited again and 58 full-grown individuals of the first Florida-grown generation and 23 ranging from quarter-grown to almost full-grown were found. Most of these speci-

TABLE No. 20.-Measurements of the first generation of Florida-grown Cerion casablance from Bahia Honda Key.

\begin{tabular}{|c|c|c|c|c|c|c|c|c|c|c|c|}
\hline \multirow{2}{*}{$\begin{array}{c}\text { Serial } \\
\text { No. }\end{array}$} & \multirow{2}{*}{$\begin{array}{l}\text { No. of } \\
\text { whorls. }\end{array}$} & \multicolumn{2}{|c|}{$\begin{array}{l}\text { Measurements } \\
\text { of shells. }\end{array}$} & \multirow{2}{*}{$\begin{array}{c}\text { Serial } \\
\text { No. }\end{array}$} & \multirow{2}{*}{$\begin{array}{l}\text { No. of } \\
\text { whorls. }\end{array}$} & \multicolumn{2}{|c|}{$\begin{array}{c}\text { Measurements } \\
\text { of shells. }\end{array}$} & \multirow{2}{*}{$\begin{array}{l}\text { Serial } \\
\text { No. }\end{array}$} & \multirow{2}{*}{$\begin{array}{l}\text { No. of } \\
\text { whorls. }\end{array}$} & \multicolumn{2}{|c|}{$\begin{array}{c}\text { Measurements } \\
\text { of shells. }\end{array}$} \\
\hline & & Alt. & Diam. & & & Alt. & Diam. & & & Alt. & Diam. \\
\hline $\begin{array}{l}1 * \\
2 * * \\
3 \\
4 \\
5\end{array}$ & $\begin{array}{l}11.0 \\
11.0 \\
10.3 \\
10.8 \\
10.7\end{array}$ & $\begin{array}{c}m m . \\
31.5 \\
32.8 \\
29.0 \\
29.8 \\
33.0\end{array}$ & $\begin{array}{l}m m . \\
13.5 \\
13.4 \\
13.3 \\
13.2 \\
13.5\end{array}$ & $\begin{array}{r}6 \\
7 \\
8 \\
9 \\
10\end{array}$ & $\begin{array}{l}10.5 \\
11.0 \\
10.4 \\
10.4 \\
10.6\end{array}$ & $\begin{array}{c}m m . \\
31.0 \\
30.2 \\
25.5 \\
24.5 \\
29.8\end{array}$ & $\begin{array}{c}m m . \\
14.4 \\
13.2 \\
12.1 \\
13.5 \\
13.0\end{array}$ & $\begin{array}{l}\text { Average. } \\
\text { Greatest. } \\
\text { Least. . }\end{array}$ & $\begin{array}{l}10.67 \\
11.0 \\
10.3\end{array}$ & $\begin{array}{l}m m . \\
29.71 \\
32.8 \\
24.5\end{array}$ & $\begin{array}{l}\mathrm{mm} . \\
13.30 \\
14.4 \\
12.1\end{array}$ \\
\hline
\end{tabular}

* Length estimated.

*** Shell not quite adult.

mens were in the ditch. The material on top of the flat seemed to have been completely wiped out by a destructive fire that had swept part of the key. We marked and measured 56 and planted 55 of them. For measurements see table 21 and for figures see plates 36 and 37 .

On May 20, 1916, we again visited Bahia Honda Key and found 22 full-grown specimens of the first Florida-grown generation; some of these were fully 150 feet from the stake where they were originally planted. Not a single specimen of the originally transplanted material was evident and it seems as if all of these had perished in the fire of 1915 to which we have referred. In 1916 the snails were largely confined to the inner edge of the ditch. The colony of Florida-grown 
individuals planted on the seaward side of the ditch seemed to have become completely lost in the very rank and dense growth of Uniola paniculata. It will be necessary to cut this down before a report can be made on this colony.

TABLE No. 21.-Measurements of the first generation of Florida-grown Cerion casablancce from Bahia Honda Key.

\begin{tabular}{|c|c|c|c|c|c|c|c|c|c|c|c|}
\hline \multirow{2}{*}{$\begin{array}{l}\text { Serial } \\
\text { No. }\end{array}$} & \multirow{2}{*}{$\begin{array}{l}\text { No. of } \\
\text { whorls. }\end{array}$} & \multicolumn{2}{|c|}{$\begin{array}{l}\text { Measurements } \\
\text { of shells. }\end{array}$} & \multirow{2}{*}{$\begin{array}{l}\text { Serial } \\
\text { No. }\end{array}$} & \multirow{2}{*}{$\begin{array}{l}\text { No. of } \\
\text { whorls. }\end{array}$} & \multicolumn{2}{|c|}{$\begin{array}{l}\text { Measurements } \\
\text { of shells. }\end{array}$} & \multirow{2}{*}{$\begin{array}{l}\text { Serial } \\
\text { No. }\end{array}$} & \multirow{2}{*}{$\begin{array}{l}\text { No. of } \\
\text { whorls. }\end{array}$} & \multicolumn{2}{|c|}{$\begin{array}{l}\text { Measurements } \\
\text { of shells. }\end{array}$} \\
\hline & & Alt. & Diam. & & & Alt. & Diam. & & & Alt. & Diam. \\
\hline 1 & 11.1 & $\begin{array}{c}m m . \\
26.9\end{array}$ & $\begin{array}{c}m m . \\
12.9\end{array}$ & 21 & 11.0 & $\begin{array}{l}m m . \\
29.5\end{array}$ & $\begin{array}{l}m m . \\
13.2\end{array}$ & 41 & 10.3 & $\begin{array}{c}m m . \\
27.3\end{array}$ & $\begin{array}{l}m m . \\
13.0\end{array}$ \\
\hline 2 & 10.3 & 27.0 & 13.0 & 22 & 10.4 & 25.5 & 12.7 & 42 & 10.9 & 29.5 & 13.1 \\
\hline 3 & 11.2 & 31.2 & 12.9 & 23 & 11.0 & 30.7 & 12.9 & 43 & 10.5 & 28.2 & 14.2 \\
\hline 4 & 10.8 & 27.0 & 12.8 & 24 & 10.3 & 28.0 & 14.0 & 44 & 11.0 & 30.0 & 12.5 \\
\hline 5 & 10.4 & 26.8 & 12.2 & 25 & 10.6 & 27.0 & 12.6 & 45 & 11.2 & 30.2 & 13.5 \\
\hline 6 & 10.5 & 29.2 & 12.5 & 26 & 10.8 & 27.5 & 11.9 & 46 & 11.3 & 31.0 & 12.5 \\
\hline 7 & 11.0 & 30.0 & 13.3 & 27 & 10.5 & 27.8 & 12.5 & 47 & 11.2 & 31.5 & 14.2 \\
\hline 8 & 10.9 & 28.7 & 12.6 & 28 & 11.2 & 28.9 & 12.5 & 48 & 11.0 & 29.0 & 12.8 \\
\hline 9 & 9.9 & 27.0 & 14.0 & 29 & 11.0 & 28.3 & 12.2 & 49 & 10.6 & 27.0 & 12.8 \\
\hline 10 & 11.4 & 27.7 & 13.5 & 30 & 10.9 & 32.7 & 13.4 & 50 & 10.6 & 25.5 & 13.0 \\
\hline 11 & 10.6 & 28.7 & 13.6 & 31 & 10.8 & 27.1 & 13.2 & 51 & 10.4 & 25.1 & 12.0 \\
\hline 12 & 11.4 & 29.8 & 13.0 & 32 & 10.3 & 28.4 & 13.0 & 52 & 10.8 & 28.2 & 12.8 \\
\hline 13 & 11.1 & 30.5 & 13.5 & 33 & 11.0 & 28.0 & 12.9 & 53 & 10.4 & 28.0 & 12.2 \\
\hline 14 & 11.0 & 28.0 & 12.2 & 34 & 10.3 & 28.3 & 13.0 & 54 & 10.8 & 29.0 & 14.0 \\
\hline 15 & 10.9 & 29.0 & 12.5 & 35 & 10.5 & 25.5 & 11.9 & 55 & 10.7 & 27.0 & 12.8 \\
\hline 16 & 10.6 & 28.0 & 12.9 & 36 & 10.4 & 27.0 & 13.0 & 56 & 11.2 & 30.5 & 12.7 \\
\hline 17 & 10.8 & 27.0 & 12.6 & 37 & 11.2 & 32.0 & 14.0 & & & & \\
\hline 18 & 10.5 & 27.2 & 13.9 & 38 & 10.5 & 26.3 & 12.6 & Average. & 10.76 & 28.4 & 12.96 \\
\hline 19 & 11.2 & 28.1 & 12.3 & 39 & 10.6 & 29.0 & 13.1 & Greatest. & 11.4 & 32.7 & 14.2 \\
\hline 20 & 10.5 & 29.0 & 13.6 & 40 & 10.6 & 29.2 & 13.5 & Least. . . & 9.9 & 25.1 & 11.9 \\
\hline
\end{tabular}

Bahia Honda was not visited in 1917 or 1918.

On January 20,1919, the planting along the sides of the ditch was doing well, and also that on the sea side of the ditch, but we were not certain whether the unmarked specimens here consisted of second generation Florida-grown material or whether these might be firstgeneration specimens which had crossed the ditch. It seemed as if the ditch might have been crossed, judging from specimens found in such locations. We were therefore unable to give these any status or to make a positive statement regarding the second generation on Bahia Honda.

\section{Colonies of Cerion casablances on Loggerhead Key.}

On this key seven plantings have been made of this species. These represent the Cerion colonies $\mathrm{A}, \mathrm{B}, \mathrm{C}, \mathrm{H}, \mathrm{I}, \mathrm{J}$, and $\mathrm{O}$.

\section{The Loggerhead Key Colony A.}

The first planting of Cerion casablancae was made on June 8, 1912, when 500 specimens were placed in a meadow covered with a sparse growth of Sporobolus virginicus, Cyperus brunneus, and cacti on the 
east side of the path, 600 feet north of the lighthouse. This colony was marked by a stake bearing the legend: "Cerions, 1912, A."

In May 1913 our animals were doing well and without much difficulty we discovered 82 young, one having as many as 7 postnuclear whorls. The cacti seemed to be making altogether too much progress in their invasion of this field, so we thinned them out materially.

In April 1914 we easily gathered 615 young in various stages of growth, from mere nepionic tips to adults; 20 adult of the first generation were figured in the 1915 report, plate 2, top and bottom rows, as well as a lot of young on plate 4 and bottom figure of plate 5 . The 100 specimens represented on the lower figure of plate 5 were marked and planted as colony 6 , while the 500 tips represented on plate 4 formed the initial planting of Colony B. The 20 adult specimens were fully discussed in the 1915 report.

TABLE No. 22.-Measurements of the first generation of Florida-grown Cerion casablanca from Loggerhead Key Colony $A$.

\begin{tabular}{|c|c|c|c|c|c|c|c|c|c|c|c|}
\hline \multirow{2}{*}{$\begin{array}{c}\text { Serial } \\
\text { No. }\end{array}$} & \multirow{2}{*}{$\begin{array}{l}\text { No. of } \\
\text { whorls. }\end{array}$} & \multicolumn{2}{|c|}{$\begin{array}{l}\text { Measurements } \\
\text { of shells. }\end{array}$} & \multirow{2}{*}{$\begin{array}{l}\text { Seria, } \\
\text { No. }\end{array}$} & \multirow{2}{*}{$\begin{array}{l}\text { No. of } \\
\text { whorls. }\end{array}$} & \multicolumn{2}{|c|}{$\begin{array}{l}\text { Measurements } \\
\text { of shells. }\end{array}$} & \multirow{2}{*}{$\begin{array}{l}\text { Serial } \\
\text { No. }\end{array}$} & \multirow{2}{*}{$\begin{array}{l}\text { No. of } \\
\text { whorls. }\end{array}$} & \multicolumn{2}{|c|}{$\begin{array}{l}\text { Measurements } \\
\text { of shells. }\end{array}$} \\
\hline & & Alt. & Diam. & & & Alt. & Diam. & & & Alt. & Diam. \\
\hline 1 & 11.4 & $\begin{array}{l}m m . \\
30.1\end{array}$ & $\begin{array}{c}m m_{.} \\
12.3\end{array}$ & 9 & 11.6 & $\begin{array}{l}m m . \\
30.2\end{array}$ & ${ }_{12.0}^{m m}$ & 16 & 10.9 & $\begin{array}{c}m m . \\
26.3\end{array}$ & $\begin{array}{l}m m . \\
11.0\end{array}$ \\
\hline 2 & 11.1 & 29.0 & 12.0 & 10 & 11.5 & 28.1 & 12.3 & 17 & 11.2 & 27.2 & 11.8 \\
\hline 3 & 10.5 & 31.7 & 13.6 & 11 & 11.2 & $* 27.8$ & 11.8 & 18 & 10.4 & 26.5 & 12.8 \\
\hline 4 & 12.0 & 34.0 & 12.3 & 12 & 11.9 & 28.2 & 12.5 & 19 & 10.6 & 26.0 & 12.0 \\
\hline 5 & 10.6 & 32.0 & 14.5 & 13 & 11.1 & 26.5 & 12.8 & & & & \\
\hline 6 & 11.3 & 28.1 & 11.7 & 14 & 10.5 & 25.0 & 11.3 & Average. & 11.17 & 28.80 & 12.28 \\
\hline 7 & 11.4 & 31.2 & 13.0 & 15 & 11.1 & 28.0 & 11.5 & Greatest & 12.0 & 34.0 & 14.5 \\
\hline 8 & 11.9 & 31.4 & 12.1 & & & & & Least. . & 10.4 & 25.0 & 11.0 \\
\hline
\end{tabular}

* Altitude estirnated; shell not adult.

In June 1915 we re-examined this colony and found it doing exceedingly well. It had spread materially; adults and young were seen everywhere within a radius of 50 feet from the stake marking the spot where the planting was first made. Some of the mollusks had taken to the fringe of bay cedars and had even crossed the path and were in the bushes at the western end of it, but preferred the grass in the shade of the shrubs. In 1914 we had placed 162 of the originally planted material at the base of the stake. Of these, we found 56 dead in 1915. The removing of the epiphragm and replanting them during the bright part of the day may have affected them adversely, and while we were easily able to find 217 adult and 47 young Florida-grown individuals in this colony, we refrained from measuring them because we feared that they might represent a mixture of first and second Florida-grown generations, so we allowed them simply to remain as they were.

In 1916, 1917, and 1919 this colony was found in a most flourishing condition. When visited in January 1919 the ground everywhere was covered with adult and young. They had crossed the path and entered 
among the bay cedars on the west side of the path, where they seemed to be thriving well. This we considered rather unusual, for our previous experience had been that they commonly avoided the ground occupied by bay cedars or the dead leaves of these plants. The region occupied by Colony $\mathrm{A}$ at present seems to be as densely populated as was the original home in the Bahamas.

\section{The Loggerhead Key Colony B.}

On June 27, 1914, Colony B was started with 500 tips (see plate 4 of the 1915 report), which were offsprings of Colony A. These were placed 150 feet distant and a little south of east of the stake which

TABLE No. 23.-Measurements of the first generation of Florida-grown Cerion casablancie from Loggerhead Key Colony $B$.

\begin{tabular}{|c|c|c|c|c|c|c|c|c|c|c|c|}
\hline \multirow{2}{*}{$\begin{array}{l}\text { Serial } \\
\text { No. }\end{array}$} & \multirow{2}{*}{$\begin{array}{l}\text { No. of } \\
\text { whorls. }\end{array}$} & \multicolumn{2}{|c|}{$\begin{array}{l}\text { Measurements } \\
\text { of shells. }\end{array}$} & \multirow{2}{*}{$\begin{array}{l}\text { Serial } \\
\text { No. }\end{array}$} & \multirow{2}{*}{$\begin{array}{l}\text { No. of } \\
\text { whorls. }\end{array}$} & \multicolumn{2}{|c|}{$\begin{array}{l}\text { Measurements } \\
\text { of shells. }\end{array}$} & \multirow{2}{*}{$\begin{array}{l}\text { Serial } \\
\text { No. }\end{array}$} & \multirow{2}{*}{$\begin{array}{l}\text { No. of } \\
\text { whorls. }\end{array}$} & \multicolumn{2}{|c|}{$\begin{array}{l}\text { Measurements } \\
\text { of shells. }\end{array}$} \\
\hline & & Alt. & Diam. & & & Alt. & Diam. & & & Alt. & Diam. \\
\hline 1 & 11.2 & $\begin{array}{c}m m_{.} \\
28.1\end{array}$ & $\begin{array}{l}m m . \\
12.0\end{array}$ & 43 & 11.4 & $\begin{array}{l}m m . \\
29.3\end{array}$ & $\begin{array}{l}m m . \\
12.1\end{array}$ & 85 & 10.7 & $m m$. & ${ }_{11.6}$ \\
\hline 2 & 11.3 & 28.5 & 11.5 & 44 & 11.7 & 31.5 & 12.2 & 86 & 11.8 & $\begin{array}{l}27.5 \\
28.4\end{array}$ & $\begin{array}{l}11.6 \\
10.9\end{array}$ \\
\hline 3 & 10.9 & 30.3 & 12.4 & 45 & 11.4 & 31.2 & 12.9 & 87 & 10.2 & 26.3 & 12.4 \\
\hline 4 & 10.7 & 29.0 & 12.1 & 46 & 11.2 & 28.7 & 11.9 & 88 & 10.8 & 26.2 & 11.0 \\
\hline 5 & 10.9 & 27.2 & 12.0 & 47 & 10.4 & 25.3 & 11.0 & 89 & 11.4 & 32.0 & 12.4 \\
\hline 6 & 11.7 & 30.2 & 11.9 & 48 & 11.2 & 29.0 & 12.0 & 90 & 11.0 & 30.8 & 12.4 \\
\hline 7 & 11.1 & 28.6 & 12.0 & 49 & 11.5 & 27.8 & 11.1 & 91 & 10.8 & 28.5 & 12.2 \\
\hline 8 & 10.6 & 27.1 & 11.4 & 50 & 10.1 & 27.3 & 13.0 & 92 & 11.4 & 30.0 & 12.5 \\
\hline 9 & 10.7 & 27.2 & 11.6 & 51 & 11.1 & 27.8 & 10.8 & 93 & 10.1 & 22.3 & 10.2 \\
\hline 10 & 11.2 & 30.0 & 12.6 & 52 & 11.1 & 26.5 & 11.2 & 94 & 10.1 & 27.5 & 11.8 \\
\hline 11 & 10.8 & 29.6 & 12.7 & 53 & 11.8 & 30.3 & 11.7 & 95 & 10.5 & 28.4 & 12.9 \\
\hline 12 & 11.0 & 30.9 & 12.0 & 54 & 11.3 & 31.0 & 12.1 & 96 & 10.8 & 26.0 & 10.8 \\
\hline 13 & 11.2 & 31.3 & 12.8 & 55 & 11.4 & 30.0 & 11.5 & 97 & 10.6 & 29.0 & 12.5 \\
\hline 14 & 11.1 & 30.0 & 12.4 & 56 & 11.2 & 29.5 & 12.9 & 98 & 11.0 & 27.6 & 12.7 \\
\hline 15 & 11.2 & 31.1 & 11.4 & 57 & 11.0 & 27.8 & 12.1 & 99 & 10.9 & 30.7 & 12.9 \\
\hline 16 & 11.2 & 29.1 & 11.7 & 58 & 10.1 & 27.5 & 11.5 & 100 & 10.5 & 26.3 & 10.9 \\
\hline 17 & 10.7 & 27.3 & 12.5 & 59 & 11.1 & 30.5 & 11.8 & 101 & 11.0 & 27.8 & 11.0 \\
\hline 18 & 10.7 & 27.4 & 11.6 & 60 & 11.1 & 28.0 & 11.1 & 102 & 10.8 & 29.2 & 13.0 \\
\hline 19 & 10.6 & 26.0 & 11.6 & 61 & 10.6 & 26.7 & 12.1 & 103 & 10.9 & 27.5 & 10.6 \\
\hline 20 & 10.9 & 30.1 & 12.0 & 62 & 10.1 & 28.2 & 12.3 & 104 & 10.9 & 26.9 & 11.2 \\
\hline 21 & 11.5 & 31.0 & 11.1 & 63 & 10.2 & 26.5 & 12.1 & 105 & 11.1 & 26.4 & 11.3 \\
\hline 22 & 10.5 & 27.0 & 11.6 & 64 & 10.3 & 25.7 & 11.1 & 106 & 12.0 & 29.0 & 11.7 \\
\hline 23 & 11.0 & 26.0 & 10.7 & 65 & 10.2 & 24.7 & 11.9 & 107 & 10.5 & 27.6 & 11.9 \\
\hline 24 & 11.0 & 29.0 & 12.0 & 66 & 10.8 & 27.4 & 12.5 & 108 & 10.4 & 26.0 & 11.4 \\
\hline 25 & 11.2 & 28.9 & 11.5 & 67 & 11.8 & 30.7 & 12.3 & 109 & 10.8 & 26.6 & 11.0 \\
\hline 26 & 10.5 & 26.5 & 11.7 & 68 & 10.9 & 27.8 & 11.6 & 110 & 10.9 & 26.5 & 10.9 \\
\hline 27 & 10.8 & 26.0 & 11.6 & 69 & 11.2 & 29.5 & 12.1 & 111 & 10.2 & 23.7 & 11.0 \\
\hline 28 & 10.8 & 25.3 & 11.0 & 70 & 11.1 & 29.1 & 12.0 & 112 & 9.5 & 27.0 & 11.7 \\
\hline 29 & 10.5 & 27.7 & 11.2 & 71 & 10.9 & 29.6 & 12.7 & 113 & 11.2 & 31.6 & 12.0 \\
\hline 30 & 10.8 & 31.0 & 12.5 & 72 & 10.1 & 24.7 & 11.2 & 114 & 11.8 & 28.7 & 12.0 \\
\hline 31 & 11.1 & 28.9 & 11.2 & 73 & 11.0 & 26.1 & 11.6 & 115 & 10.3 & 26.5 & 12.0 \\
\hline 32 & 11.4 & 30.6 & 12.1 & 74 & 11.2 & 27.5 & 11.4 & 116 & 10.6 & 27.8 & 11.5 \\
\hline 33 & 11.4 & 27.6 & 10.7 & 75 & 10.6 & 28.2 & 12.3 & 117 & 10.8 & 29.1 & 11.8 \\
\hline 34 & 10.0 & 27.2 & 12.3 & 76 & 10.4 & 26.7 & 11.8 & 118 & 10.6 & 26.0 & 11.5 \\
\hline 35 & 10.5 & 28.7 & 12.0 & 77 & 10.8 & 27.0 & 11.5 & 119 & 10.6 & 28.6 & 11.9 \\
\hline 36 & 11.8 & 30.0 & 12.1 & 78 & 10.2 & 25.0 & 11.0 & 120 & 10.7 & 26.8 & 11.8 \\
\hline 37 & 10.7 & 29.6 & 11.9 & 79 & 10.8 & 29.5 & 12.7 & 121 & 10.6 & 27.4 & 11.6 \\
\hline 38 & 11.9 & 30.4 & 12.0 & 80 & 10.4 & 28.0 & 12.3 & 122 & 10.8 & 26.5 & 11.0 \\
\hline 39 & 10.8 & 28.7 & 12.0 & 81 & 10.5 & 27.0 & 12.7 & & & & \\
\hline 40 & 11.2 & 30.6 & 12.8 & 82 & 10.4 & 24.3 & 11.0 & Average. & 10.87 & 28.11 & 11.82 \\
\hline 41 & 10.7 & 29.2 & 12.2 & 83 & 10.7 & 27.1 & 12.2 & Greatest. & 12.0 & 32.0 & 13.0 \\
\hline 42 & 10.9 & 27.7 & 12.9 & 84 & 11.1 & 26.7 & 11.5 & Least... & 9.5 & 22.3 & 10.2 \\
\hline
\end{tabular}


marked the original planting. They were in the southeast corner of the same meadow in which the original planting was made, in conditions apparently identical with those prevailing in the territory occupied by Colony A. The place is marked with a stake bearing the legend "Cerions X."

On June 28, 1915, we recovered 122 full-grown and 17 immature specimens from this colony; these we measured, marked, photographed, and planted in a new location as Colony $\mathrm{J}$, which see. Their measurements are given in table 23 and their photographs are shown on plates 38 to 41 .

In May 1916 we gathered 73 adults of the first generation of Floridagrown individuals. Measurements of these are given in table 24, the specimens are figured on plates 42 and 43 .

TABLE No. 24.-Measurements of the first generation of Florida-grown Cerion casablanca from Loggerhead Key Colony $B$.

\begin{tabular}{|c|c|c|c|c|c|c|c|c|c|c|c|}
\hline \multirow{2}{*}{$\begin{array}{l}\text { Serial } \\
\text { No. }\end{array}$} & \multirow{2}{*}{$\begin{array}{l}\text { No, of } \\
\text { whorls }\end{array}$} & \multicolumn{2}{|c|}{$\begin{array}{c}\text { Measurements } \\
\text { of shells. }\end{array}$} & \multirow{2}{*}{$\begin{array}{l}\text { Serial } \\
\text { No. }\end{array}$} & \multirow{2}{*}{$\begin{array}{l}\text { No. of } \\
\text { whorls. }\end{array}$} & \multicolumn{2}{|c|}{$\begin{array}{c}\text { Measurements } \\
\text { of shells. }\end{array}$} & \multirow{2}{*}{$\begin{array}{l}\text { Serial } \\
\text { No. }\end{array}$} & \multirow{2}{*}{$\begin{array}{l}\text { No. of } \\
\text { whorls. }\end{array}$} & \multicolumn{2}{|c|}{$\begin{array}{c}\text { Measurements } \\
\text { of shells. }\end{array}$} \\
\hline & & Alt. & Diam. & & & Alt. & Diam. & & & Alt. & Diam. \\
\hline & & $m m$. & $m m$ & & & $m m$. & $m m$. & & & $m m$ & $m m$ \\
\hline 1 & 11.3 & 28.8 & 12.3 & 27 & 11.3 & 29.0 & 12.0 & 53 & 10.7 & 27.7 & 11.8 \\
\hline 2 & 11.5 & 30.0 & 13.5 & 28 & 10.5 & 27.5 & 13.0 & 54 & 10.3 & 27.3 & 12.5 \\
\hline 3 & 10.7 & 27.6 & 13.1 & 29 & 11.0 & 27.5 & 12.5 & 55 & 11.6 & 31.5 & 12.8 \\
\hline 4 & 10.6 & 27.7 & 13.5 & 30 & 11.7 & 29.1 & 11.5 & 56 & 11.4 & 31.4 & 13.0 \\
\hline 5 & 10.7 & 28.0 & 12.0 & 31 & 11.7 & 30.0 & 12.0 & 57 & 10.8 & 29.5 & 12.3 \\
\hline 6 & 11.3 & 32.2 & 13.0 & 32 & 10.8 & 27,1 & 12.1 & 58 & 10.8 & 30.0 & 12.5 \\
\hline 7 & 11.0 & 29.2 & 13.0 & 33 & 10.2 & 27.4 & 13.0 & 59 & 11.4 & 29.0 & 12.5 \\
\hline 8 & 11.2 & 30.0 & 12.4 & 34 & 11.1 & 27.8 & 12.3 & 60 & 10.9 & 30.8 & 13.7 \\
\hline 9 & 11.0 & 28.8 & 12.5 & 35 & 11.8 & 31.5 & 12.3 & 61 & 10.4 & 28.5 & 13.0 \\
\hline 10 & 11.4 & 31.5 & 13.1 & 36 & 11.0 & 30.0 & 13.2 & 62 & 10.9 & 27.9 & 12.5 \\
\hline 11 & 10.1 & 25.5 & 12.4 & 37 & 10.1 & 23.2 & 12.2 & 63 & 11.0 & 29.0 & 12.3 \\
\hline 12 & 11.5 & 28.5 & 12.0 & 38 & 10.2 & 28.3 & 12.7 & 64 & 10.1 & 29.5 & 13.1 \\
\hline 13 & 10.7 & 28.0 & 12.9 & 39 & 11.0 & 32.7 & 13.9 & 65 & 11.2 & 29.7 & 12.0 \\
\hline 14 & 10.4 & 26.2 & 13.0 & 40 & 10.7 & 28.2 & 12.5 & 66 & 11.3 & 30.0 & 11.8 \\
\hline 15 & 11.4 & 30.2 & 13.1 & 41 & 11.2 & 29.2 & 11.5 & 67 & 10.8 & 27.7 & 13.0 \\
\hline 16 & 10.7 & 28.0 & 12.5 & 42 & 12.0 & 31.2 & 13.0 & 68 & 11.0 & 29.6 & 12.0 \\
\hline 17 & 10.9 & 29.0 & 12.2 & 43 & 10.2 & 25.7 & 12.0 & 69 & 11.2 & 29.2 & 12.3 \\
\hline 18 & 11.0 & 29.0 & 12.5 & 44 & 11.2 & 29.3 & 13.0 & 70 & 10.7 & 27.0 & 12.4 \\
\hline 19 & 11.1 & 31.0 & 13.8 & 45 & 10.1 & 26.7 & 12.1 & 71 & 11.1 & 26.6 & 11.5 \\
\hline 20 & 12.4 & 34.4 & 14.0 & 46 & 11.6 & 26.7 & 11.8 & 72 & 11.3 & 29.5 & 13.2 \\
\hline 21 & 10.6 & 26.4 & 13.5 & 47 & 11.0 & 27.7 & 12.5 & 73 & 11.0 & 27.7 & 11.6 \\
\hline 22 & 10.6 & 29.2 & 13.2 & 48 & 10.2 & 25.0 & 12.5 & & & & \\
\hline 23 & 10.7 & 28.6 & 12.5 & 49 & 11.3 & 29.4 & 12.7 & Average. & 10.96 & 28.7 & 12.59 \\
\hline 24 & 11.1 & 27.4 & 12.3 & 50 & 10.7 & 26.9 & 12.3 & Greatest. & 12.4 & 34.4 & 14.0 \\
\hline 25 & 10.7 & 28.0 & 12.7 & 51 & 10.9 & 28.3 & 12.8 & Least... & 10.1 & 23.2 & 11.5 \\
\hline 26 & 11.3 & 30.0 & 13.1 & 52 & 10.6 & 27.2 & 12.1 & & & & \\
\hline
\end{tabular}

Loggerhead Key Colony C.

On June 27, 1914, we planted 100 marked immature specimens of the first generation of Florida-grown individuals from Colony A, on the west side of the path between the laboratory and the lighthouse, about 135 feet south of the stake marking Colony A. This planting was in the northeast corner of a large meadow bearing a tag with the legend "Cerions Y." 
On June 27, 1915, we recovered 36 adults, which were measured, photographed, and replaced. The measurements can be seen in table 25 and the specimens are depicted on plate 44 .

$\mathrm{T}_{\mathrm{ABLE}}$ No. 25.-Measurements of the first generation of Florida-grown Cerion casablancee from Loggerhead Key Colony C.

\begin{tabular}{|c|c|c|c|c|c|c|c|c|c|c|c|}
\hline \multirow{2}{*}{$\begin{array}{c}\text { Serial } \\
\text { No. }\end{array}$} & \multirow{2}{*}{$\begin{array}{l}\text { No. of } \\
\text { whorls. }\end{array}$} & \multicolumn{2}{|c|}{$\begin{array}{l}\text { Measurements } \\
\text { of shell. }\end{array}$} & \multirow{2}{*}{$\begin{array}{l}\text { Serial } \\
\text { No. }\end{array}$} & \multirow{2}{*}{$\begin{array}{l}\text { No. of } \\
\text { whorls. }\end{array}$} & \multicolumn{2}{|c|}{$\begin{array}{l}\text { Measurements } \\
\text { of shell. }\end{array}$} & \multirow{2}{*}{$\begin{array}{l}\text { Serial } \\
\text { No. }\end{array}$} & \multirow{2}{*}{$\begin{array}{l}\text { No. of } \\
\text { whorls. }\end{array}$} & \multicolumn{2}{|c|}{$\begin{array}{l}\text { Measurements } \\
\text { of shell. }\end{array}$} \\
\hline & & Alt. & Diam. & & & Alt. & Diam. & & & Alt. & Diam. \\
\hline 1 & 10.8 & $\begin{array}{l}m m . \\
26.2\end{array}$ & $\begin{array}{c}m m . \\
10.0\end{array}$ & 15 & 11.0 & $\begin{array}{l}m m . \\
28.0\end{array}$ & $\begin{array}{l}m m . \\
12.0\end{array}$ & 29 & 10.5 & $\begin{array}{c}m m . \\
27.3\end{array}$ & $\mathrm{~mm}$. \\
\hline 2 & 11.0 & 27.4 & 11.1 & 16 & 10.9 & 31.5 & 12.1 & 30 & 10.8 & 25.7 & 10.5 \\
\hline 3 & 11.0 & 28.5 & 12.0 & 17 & 11.4 & 30.0 & 12.4 & 31 & 11.0 & 28.5 & 12.5 \\
\hline 4 & 11.8 & 30.2 & 11.9 & 18 & 10.1 & 24.3 & 11.2 & 32 & 11.2 & 27.5 & 11.6 \\
\hline 5 & 11.1 & 26.1 & 11.2 & 19 & 10.3 & 25.5 & 11.1 & 33 & 11.4 & 28.3 & 11.5 \\
\hline 6 & 10.8 & 29.6 & 12.2 & 20 & 10.6 & 27.0 & 11.9 & 34 & 11.4 & 26.5 & 11.1 \\
\hline 7 & 10.8 & 29.7 & 13.1 & 21 & 10.7 & 28.0 & 12.0 & 35 & 11.2 & 30.6 & 12.0 \\
\hline 8 & 10.1 & 30.0 & 13.1 & 22 & 10.7 & 27.7 & 11.8 & 36 & 10.8 & 30.0 & 12.6 \\
\hline 9 & 10.7 & 26.9 & 11.4 & 23 & 11.2 & 28.4 & 11.6 & & & & \\
\hline 10 & 10.5 & 26.8 & 11.6 & 24 & 10.1 & 27.3 & 13.0 & Average. & 10.9 & 28.26 & 11.83 \\
\hline 11 & 10.8 & 28.2 & 11.3 & 25 & 10.8 & 26.5 & 12.5 & Greatest. & 11.8 & 31.9 & 13.1 \\
\hline 12 & 10.7 & 27.9 & 11.6 & 26 & 11.0 & 31.3 & 12.8 & Least... & 10.1 & 24.3 & 10.0 \\
\hline 13 & 11.5 & 30.9 & 11.4 & 27 & 10.9 & 28.8 & 12.3 & & & & \\
\hline 14 & 11.8 & 31.9 & 11.4 & 28 & 11.1 & 28.3 & 11.7 & & & & \\
\hline
\end{tabular}

In May 1916 we added to this colony 73 adults of the first-grown Florida generation from Colony $\mathrm{B}$, and also the 7 living specimens from Colony J.

In July 1917 we found 9 specimens of the second generation.

In 1918 the colony was not visited, but in January 1919 we found 100 adult specimens of the second generation from this colony. Measurements of these are shown in table 26 and figures thereof are given on plates 45-47. These specimens, together with 25 tips of the second generation, were planted as Colony O. (See page 43.)

The Loggerhead $K_{\text {ey }}$ Colonies $\mathrm{H}$ and $\mathrm{I}$.

These are discussed under Colonies $\mathrm{H}$ and $\mathrm{I}$ of Cerion viaregis. (See pages 25 and 26.)

The Loggerhead Key Colony J.

In June 1915 we placed 122 adult and 14 immature Florida-grown, first-generation Cerions in a little clearing on the east side of the path, halfway between the laboratory and Colony A. The place was marked by a stake and a tag bearing the legend "Cerions, 1915, J."

In May 1916 we recovered 121 of these, but all except 7 were dead. They had not left the region about the stake where we had dropped them. It is probable that our planting them during the heat of the day with their epiphragm broken may have had this disastrous effect. The 7 living specimens were placed with Colony C.

No specimens were observed in 1917, but in January 1919 we found a few in the region of this planting, which goes to show that it is never quite safe to say that a colony is extinct. 
TABLE No. 26.-Measurements of the second generation of Florida-grown Cerion casablancee from Loggerhead Key Colony C.

\begin{tabular}{|c|c|c|c|c|c|c|c|c|c|c|c|}
\hline \multirow{2}{*}{$\begin{array}{c}\text { Serial } \\
\text { No. }\end{array}$} & \multirow{2}{*}{$\begin{array}{l}\text { No. of } \\
\text { whorls. }\end{array}$} & \multicolumn{2}{|c|}{$\begin{array}{l}\text { Measurements } \\
\text { of shell. }\end{array}$} & \multirow{2}{*}{$\begin{array}{l}\text { Serial } \\
\text { No. }\end{array}$} & \multirow{2}{*}{$\begin{array}{l}\text { No. of } \\
\text { whorls. }\end{array}$} & \multicolumn{2}{|c|}{$\begin{array}{l}\text { Measurements } \\
\text { of shell. }\end{array}$} & \multirow{2}{*}{$\begin{array}{l}\text { Serial } \\
\text { No. }\end{array}$} & \multirow{2}{*}{$\begin{array}{l}\text { No. of } \\
\text { whorls. }\end{array}$} & \multicolumn{2}{|c|}{$\begin{array}{l}\text { Measurements } \\
\text { of shell. }\end{array}$} \\
\hline & & Alt. & Diam. & & & Alt. & Diam. & & & Alt. & Diam. \\
\hline 1 & 10.9 & $\begin{array}{l}m m . \\
27.3\end{array}$ & $\begin{array}{c}m m . \\
13.2\end{array}$ & 36 & 10.1 & $\begin{array}{l}m m . \\
27.1\end{array}$ & $\begin{array}{c}m m . \\
13.0\end{array}$ & 71 & 9.8 & $\begin{array}{l}m m . \\
26.7\end{array}$ & $\begin{array}{l}m m . \\
12.5\end{array}$ \\
\hline 2 & 11.0 & 27.9 & 14.1 & 37 & 10.3 & 28.1 & 14.0 & 72 & 10.3 & 27.0 & 14.6 \\
\hline 3 & 11.4 & 30.2 & 13.4 & 38 & 10.3 & 24.2 & 11.6 & 73 & 11.1 & 27.3 & 12.3 \\
\hline 4 & 12.1 & 30.0 & 13.0 & 39 & 11.2 & 25.7 & 12.1 & 74 & 10.7 & 28.3 & 13.7 \\
\hline 5 & 10.6 & 28.0 & 13.7 & 40 & 11.2 & 26.7 & 13.5 & $7 \overline{5}$ & 9.9 & 23.5 & 12.2 \\
\hline 6 & 11.2 & 28.9 & 12.2 & 41 & 10.5 & 26.2 & 14.6 & 76 & 11.3 & 28.5 & 12.5 \\
\hline 7 & 11.1 & 28.3 & 12.6 & 42 & 11.1 & 29.1 & 13.5 & 77 & 11.1 & 28.1 & 13.7 \\
\hline 8 & 11.1 & 27.5 & 12.7 & 43 & 11.4 & 27.4 & 13.5 & 78 & 10.6 & 24.5 & 12.7 \\
\hline 9 & 11.5 & 30.1 & 14.0 & 44 & 10.8 & 29.3 & 12.5 & 79 & 10.6 & 27.4 & 13.3 \\
\hline 10 & 10.7 & 26.5 & 13.4 & 45 & 11.1 & 27.8 & 13.7 & 80 & 11.1 & 29.1 & 12.5 \\
\hline 11 & 10.7 & 27.8 & 13.0 & 46 & 11.3 & 29.0 & 14.4 & 81 & 10.3 & 24.5 & 12.7 \\
\hline 12 & 10.1 & 24.2 & 12.5 & 47 & 11.1 & 27.8 & 13.7 & 82 & 11.1 & 27.6 & 13.6 \\
\hline 13 & 10.9 & 28.4 & 12.7 & 48 & 11.0 & 28.0 & 13.3 & 83 & 11.0 & 27.5 & 12.1 \\
\hline 14 & 10.8 & 26.2 & 13.1 & 49 & 10.0 & 25.6 & 14.8 & 84 & 10.6 & 28.3 & 12.7 \\
\hline 15 & 11.4 & 27.5 & 13.3 & 50 & 11.2 & 27.6 & 13.4 & 85 & 11.6 & 28.5 & 12.0 \\
\hline 16 & 10.2 & 27.5 & 13.7 & 51 & 10.8 & 25.9 & 13.0 & 86 & 10.2 & 25.5 & 13.2 \\
\hline 17 & 10.6 & 25.1 & 12.2 & 52 & 10.5 & 27.0 & 13.0 & 87 & 10.9 & 25.8 & 11.8 \\
\hline 18 & 11.2 & 29.6 & 14.0 & 53 & 10.5 & 25.0 & 11.9 & 88 & 11.5 & 28.7 & 12.9 \\
\hline 19 & 11.4 & 27.9 & 11.8 & 54 & 10.1 & 24.5 & 12.7 & 89 & 11.0 & 28.2 & 13.7 \\
\hline 20 & 11.5 & 28.9 & 14.0 & 55 & 10.7 & 24.0 & 12.7 & 90 & 11.1 & 26.1 & 11.5 \\
\hline 21 & 10.2 & 23.7 & 11.3 & 56 & 11.0 & 27.3 & 12.0 & 91 & 10.6 & 26.9 & 13.2 \\
\hline 22 & 10.3 & 26.4 & 12.8 & 57 & 10.0 & 25.8 & 12.5 & 92 & 11.1 & 28.1 & 13.5 \\
\hline 23 & 11.1 & 25.6 & 12.3 & 58 & 10.6 & 26.9 & 12.4 & 93 & 10.6 & 26.7 & 13.1 \\
\hline 24 & 11.4 & 29.0 & 12.3 & 59 & 9.9 & 25.8 & 13.5 & 94 & 10.6 & 25.2 & 12.5 \\
\hline 25 & 11.3 & 30.7 & 14.0 & 60 & 10.7 & 28.2 & 12.7 & 95 & 10.4 & 25.4 & 12.0 \\
\hline 26 & 11.7 & 31.3 & 14.2 & 61 & 9.7 & 24.6 & 12.1 & 96 & 11.4 & 28.2 & 13.2 \\
\hline 27 & 10.8 & 26.3 & 11.7 & 62 & 11.6 & 29.0 & 13.0 & 97 & 11.4 & 27.6 & 12.7 \\
\hline 28 & 10.8 & 25.1 & 10.1 & 63 & 10.9 & 29.1 & 13.0 & 98 & 11.1 & 26.7 & 12.6 \\
\hline 29 & 11.2 & 29.7 & 13.0 & 64 & 10.4 & 28.0 & 13.0 & 99 & 9.8 & 23.2 & 11.8 \\
\hline 30 & 11.5 & 30.7 & 13.0 & 65 & 10.8 & 29.0 & 13.2 & 100 & 10.4 & 24.6 & 11.3 \\
\hline 31 & 10.2 & 27.6 & 12.8 & 66 & 10.0 & 24.4 & 12.1 & & & & \\
\hline 32 & 11.0 & 27.2 & 12.6 & 67 & 10.8 & 28.2 & 12.8 & Average. & 10.83 & 27.2 & 12.91 \\
\hline 33 & 11.1 & 27.0 & 12.8 & 68 & 10.7 & 25.7 & 12.7 & Greatest. & 12,1 & 31.3 & 14.8 \\
\hline 34 & 12.0 & 30.8 & 14.0 & 69 & 11.0 & 25.9 & 13.1 & Least. . . & 9.7 & 23.2 & 10.1 \\
\hline 35 & 10.2 & 26.1 & 13.0 & 70 & 11.1 & 27.5 & 13.5 & & & & \\
\hline
\end{tabular}

The Loggerhead Key Colony $O$.

This colony was started January 14, 1919, and consists of 100 adult shells (figured on plates 45-47) whose measurements are given in table 26 , together with 25 tips of the second generation of Florida-grown individuals. They were taken from Colony $\mathrm{C}$ and were planted in a little meadow off the northeast corner of the laboratory. 


\section{DISCUSSION OF THE DATA.}

\section{First Gengration of Florida-grown Cerion casablancat.}

An examination of the first generation of Cerion casablanca grown on the various Florida keys reveals the fact that, so as far as type of structure is concerned, no deviation appears to have taken place beyond that found in material from the White House region of Andros. An analysis of the measurements of the first generation gives the results shown in table 27.

TABLE No. 27.-First generation Florida-grown Cerion casablanca.

\begin{tabular}{|c|c|c|c|c|}
\hline Colony. & $\begin{array}{l}\text { No. of } \\
\text { whorls. }\end{array}$ & Altitude. & $\begin{array}{c}\text { Greater } \\
\text { diameter. }\end{array}$ & $\begin{array}{c}\text { No. of } \\
\text { specimens. }\end{array}$ \\
\hline 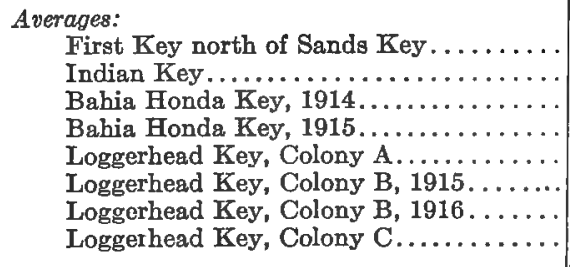 & $\begin{array}{l}10.45 \\
10.50 \\
10.67 \\
10.76 \\
11.17 \\
10.87 \\
10.96 \\
10.90\end{array}$ & $\begin{array}{l}m m . \\
28.31 \\
27.45 \\
29.71 \\
28.40 \\
28.80 \\
28.11 \\
28.70 \\
28.26\end{array}$ & $\begin{array}{l}m m . \\
14.10 \\
12.72 \\
13.30 \\
12.96 \\
12.28 \\
11.82 \\
12.59 \\
11.83\end{array}$ & $\begin{array}{r}23 \\
18 \\
10 \\
56 \\
19 \\
122 \\
73 \\
36\end{array}$ \\
\hline 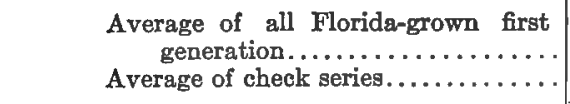 & $\begin{array}{l}10.79 \\
10.92\end{array}$ & $\begin{array}{l}28.47 \\
27.19\end{array}$ & $\begin{array}{l}12.70 \\
13.70\end{array}$ & $\begin{array}{c}4463 \\
\ldots \ldots \ldots\end{array}$ \\
\hline 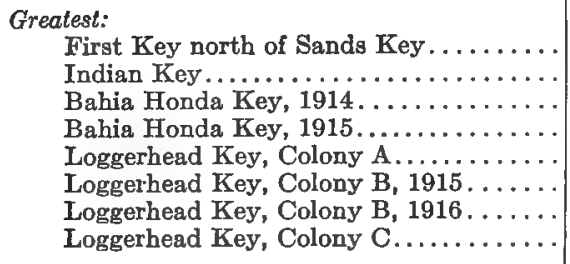 & $\begin{array}{l}11.10 \\
11.30 \\
11.00 \\
11.40 \\
12.00 \\
12.00 \\
12.40 \\
11.80\end{array}$ & $\begin{array}{l}32.00 \\
31.00 \\
32.80 \\
32.70 \\
34.00 \\
32.00 \\
34.40 \\
31.90\end{array}$ & $\begin{array}{l}15.00 \\
13.80 \\
14.40 \\
14.20 \\
14.50 \\
13.00 \\
14.00 \\
13.10\end{array}$ & \\
\hline $\begin{array}{r}\text { Greatest of all Florida-grown first } \\
\text { generation.................... } \\
\text { Greatest of check series.......... }\end{array}$ & $\begin{array}{l}12.40 \\
12.10\end{array}$ & $\begin{array}{l}34.40 \\
32.90\end{array}$ & $\begin{array}{l}15.00 \\
15.60\end{array}$ & \\
\hline 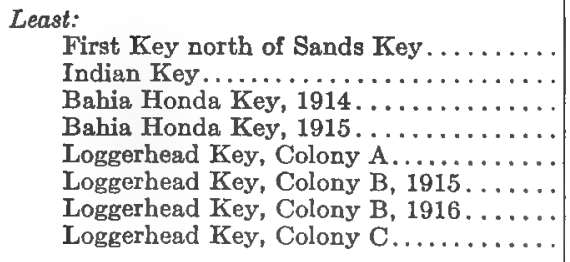 & $\begin{array}{r}10.00 \\
9.80 \\
10.30 \\
9.40 \\
10.40 \\
9.50 \\
10.10 \\
10.10\end{array}$ & $\begin{array}{l}24.00 \\
24.00 \\
24.50 \\
25.10 \\
25.00 \\
22.30 \\
23.20 \\
24.30\end{array}$ & $\begin{array}{l}12.50 \\
11.80 \\
12.10 \\
11.90 \\
11.00 \\
10.20 \\
11.50 \\
10.00\end{array}$ & \\
\hline 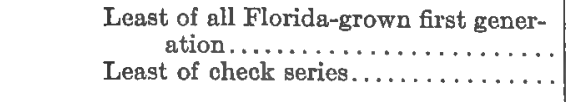 & $\begin{array}{r}9.40 \\
10.00\end{array}$ & $\begin{array}{l}22.30 \\
24.00\end{array}$ & $\begin{array}{l}10.00 \\
11.00\end{array}$ & \\
\hline
\end{tabular}

This analysis shows that we have a little larger range of variation in the first Florida-grown generation than in the check series from Andros Island, Bahamas. In the number of whorls the Florida-grown specimens vary from 12.4 to 9.4 , while the check series varies from 12.1 to 10 . 
In altitude our Florida-grown material varies from $34.4 \mathrm{~mm}$. to 22.3 $\mathrm{mm}$. as against $32.9 \mathrm{~mm}$. to $24 \mathrm{~mm}$. in the check series. In diameter our Florida-grown specimens vary from $15 \mathrm{~mm}$. to $10 \mathrm{~mm}$., while in the check series the variation is from $15.6 \mathrm{~mm}$. to $11 \mathrm{~mm}$. These measurements, however, it should be remembered, cover 4,463 specimens and were we to examine a check series of equal size it is not at all improbable that these slight differences would also be present. In other words, the measurable characters show no decided change over anything that one might find in the Bahama material.

Of the second generation of Florida-grown specimens we have so far obtained only 102 specimens. These, like the first generation, show a little wider range of variation in measurements, but no differences in shell characters. The range of variation here is 12.1 to 9.7 whorls, while in the check series it is 12.1 to 10 . In altitude the second generation varies from $31.3 \mathrm{~mm}$. to $23.2 \mathrm{~mm}$. against $32.9 \mathrm{~mm}$. and $24 \mathrm{~mm}$. of the check series. In greater diameter the variation is $15 \mathrm{~mm}$. to $10.1 \mathrm{~mm}$. against $15.6 \mathrm{~mm}$. and $11 \mathrm{~mm}$. We may therefore say that the summary remarks applying to the first generation also obtain here. Table 28 gives a little more detailed account of this generation.

TABLE No. 28.-Second generation Floridargrown Cerion casablance.

\begin{tabular}{|c|c|c|c|c|}
\hline Colony. & $\begin{array}{l}\text { No. of } \\
\text { whorls. }\end{array}$ & Altitude. & $\begin{array}{c}\text { Greater } \\
\text { diameter. }\end{array}$ & $\begin{array}{c}\text { No. of } \\
\text { specimens }\end{array}$ \\
\hline 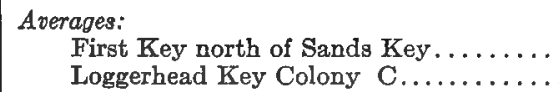 & $\begin{array}{l}10.60 \\
10.83\end{array}$ & $\begin{array}{l}m m . \\
28.95 \\
27.20\end{array}$ & $\begin{array}{l}m m . \\
14.70 \\
12.91\end{array}$ & $\begin{array}{r}2 \\
100\end{array}$ \\
\hline 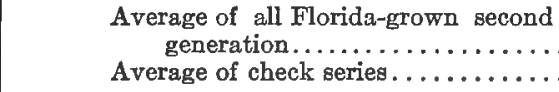 & $\begin{array}{l}10.71 \\
10.92\end{array}$ & $\begin{array}{l}28.07 \\
27.19\end{array}$ & $\begin{array}{l}13.80 \\
13.70\end{array}$ & 102 \\
\hline 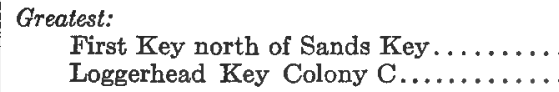 & $\begin{array}{l}11.00 \\
12.10\end{array}$ & $\begin{array}{l}31.30 \\
31.30\end{array}$ & $\begin{array}{l}15.00 \\
14.80\end{array}$ & \\
\hline 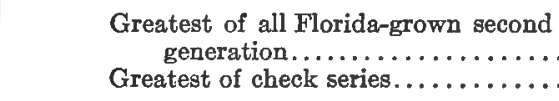 & $\begin{array}{l}12.10 \\
12.10\end{array}$ & $\begin{array}{l}31.30 \\
32.90\end{array}$ & $\begin{array}{l}15.00 \\
15.60\end{array}$ & \\
\hline 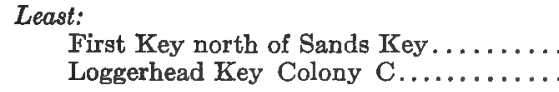 & $\begin{array}{r}10.20 \\
9.70\end{array}$ & $\begin{array}{l}26.60 \\
23.20\end{array}$ & $\begin{array}{l}14.40 \\
10.10\end{array}$ & \\
\hline 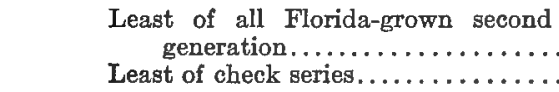 & $\begin{array}{r}9.70 \\
10.00\end{array}$ & $\begin{array}{l}22.20 \\
24.00\end{array}$ & $\begin{array}{l}10.10 \\
11.00\end{array}$ & \\
\hline
\end{tabular}

Cerion Crassilabris ("Shuttleworth" Sowerby).

The Loggerhead Key Colony L.

In May 1915 Dr. Mayor collected a lot of specimens of Cerion crassilabris, at Balena Point, near Guanico Bay, Porto Rico, 800 of which we 
planted in June of the same year in a little meadow on the west side of the south end of the island. The place of the planting is covered by a moderate growth of Uniola paniculata and is marked by a stake bearing a tag with the legend, "Porto Rico, 1915."

The check series, consisting of 100 specimens, Cat. No. 334724 U. S. N. M., taken at random from the collection which furnished the material planted on Loggerhead Key, yields the measurements shown in table 29. The specimens are figured on plates $48-50$.

TABLE No. 29.-Check series of Cerion crassilabris.

\begin{tabular}{|c|c|c|c|c|c|c|c|c|c|c|c|}
\hline \multirow{2}{*}{$\begin{array}{l}\text { Serial } \\
\text { No. }\end{array}$} & \multirow{2}{*}{$\begin{array}{l}\text { No, of } \\
\text { whorls. }\end{array}$} & \multicolumn{2}{|c|}{$\begin{array}{l}\text { Measurements } \\
\text { of shells. }\end{array}$} & \multirow{2}{*}{$\begin{array}{l}\text { Serial } \\
\text { No. }\end{array}$} & \multirow{2}{*}{$\begin{array}{l}\text { No. of } \\
\text { whorls. }\end{array}$} & \multicolumn{2}{|c|}{$\begin{array}{l}\text { Measurements } \\
\text { of shells. }\end{array}$} & \multirow{2}{*}{$\begin{array}{l}\text { Serial } \\
\text { No. }\end{array}$} & \multirow{2}{*}{$\begin{array}{l}\text { No. of } \\
\text { whorls. }\end{array}$} & \multicolumn{2}{|c|}{$\begin{array}{l}\text { Measurements } \\
\text { of shells. }\end{array}$} \\
\hline & & Alt. & Diam. & & & Alt. & Diam. & & & Alt. & Diam. \\
\hline 1 & 10.3 & $m m$. & $m m$. & 36 & 9.5 & $m m$. & $m m$. & 71 & 92 & $m m$. & $m m$. \\
\hline 2 & 10.5 & 25.8 & 13.9 & 37 & 10.0 & 22.1 & 10.9 & $\begin{array}{l}11 \\
72\end{array}$ & $\begin{array}{l}9.2 \\
9.3\end{array}$ & $\begin{array}{l}21.3 \\
21.2\end{array}$ & $\begin{array}{l}12.2 \\
12.2\end{array}$ \\
\hline 3 & 10.1 & 25.1 & 13.0 & 38 & 10.3 & 23.2 & 12.3 & 73 & 9.5 & 21.1 & 12.0 \\
\hline 4 & 10.3 & 25.0 & 13.3 & 39 & 9.6 & 22.1 & 11.3 & 74 & 9.8 & 20.6 & 11.8 \\
\hline 5 & 10.4 & 25.2 & 13.2 & 40 & 9.6 & 22.6 & 11.8 & 75 & 9.5 & 20.5 & 11.5 \\
\hline 6 & 10.0 & 25.0 & 13.5 & 41 & 9.4 & 22.0 & 12.0 & 76 & 9.0 & 20.2 & 13.2 \\
\hline 7 & 9.4 & 24.0 & 12.3 & 42 & 9.5 & 22.0 & 12.8 & 77 & 9.1 & 21.1 & 13.0 \\
\hline 8 & 9.7 & 24.2 & 10.6 & 43 & 10.3 & 23.2 & 12.1 & 78 & 9.3 & 21.5 & 13.0 \\
\hline 9 & 10.2 & 25.4 & 13.5 & 44 & 9.8 & 22.2 & 12.2 & 79 & 9.3 & 21.3 & 13.2 \\
\hline 10 & 10.3 & 25.0 & 13.6 & 45 & 9.5 & 22.1 & 13.8 & 80 & 9.2 & 21.0 & 12.6 \\
\hline 11 & 10.5 & 23.5 & 11.9 & 46 & 9.3 & 22.0 & 12.5 & 81 & 9.6 & 21.0 & 12,2 \\
\hline 12 & 9.3 & 22.1 & 12.2 & 47 & 9.5 & 22.6 & 12.6 & 82 & 8.5 & 20.0 & 12.3 \\
\hline 13 & 10.0 & 24.0 & 13.2 & 48 & 9.7 & 22.0 & 12.0 & 83 & 9.5 & 21.2 & 12.1 \\
\hline 14 & 10.0 & 23.5 & 13.5 & 49 & 9.9 & 21.3 & 11.6 & 84 & 9.2 & 21.3 & 12.8 \\
\hline 15 & 9.4 & 24.0 & 13.0 & 50 & 9.9 & 22.5 & 11.8 & 85 & 9.2 & 20.9 & 12.2 \\
\hline 16 & 9.5 & 24.0 & 12.7 & 51 & 9.6 & 22.7 & 13.2 & 86 & 9.5 & 21.5 & 11.8 \\
\hline 17 & 9.5 & 23.0 & 13.6 & 52 & 9.5 & 22.2 & 12.0 & 87 & 9.5 & 21.2 & 12.1 \\
\hline 18 & 9.4 & 24.2 & 13.2 & 53 & 9.6 & 22.5 & 12.8 & 88 & 9.3 & 21.0 & 12.0 \\
\hline 19 & 9.5 & 23.8 & 13.8 & 54 & 9.0 & 21.0 & 12.1 & 89 & 9.3 & 20.4 & $\mathrm{I1.4}$ \\
\hline 20 & 10.2 & 23.1 & 13.1 & 55 & 9.5 & 21.5 & 12.0 & 90 & 9.3 & 20.5 & 11.5 \\
\hline 21 & 10.0 & 23.0 & 12.2 & 56 & 9.2 & 21.1 & 12.5 & 91 & 9.2 & 19.4 & 12.0 \\
\hline 22 & 9.5 & 22.7 & 11.8 & 57 & 9.1 & 20.8 & 11.3 & 92 & 8.9 & 19.6 & 11.9 \\
\hline 23 & 10.0 & 23.6 & 12.4 & 58 & 9.4 & 22.0 & 11.8 & 93 & 9.2 & 20.2 & 11.8 \\
\hline 24 & 9.3 & 22.4 & 11.6 & 59 & 9.3 & 20.5 & 12.3 & 94 & 9.0 & 19.6 & 11.6 \\
\hline 25 & 10.2 & 23.6 & 11.9 & 60 & 10.1 & 21.2 & 11.2 & 95 & 9.2 & 19.3 & 11.2 \\
\hline 26 & 9.3 & 23.2 & 12.3 & 61 & 9.4 & 21.5 & 12.1 & 96 & 9.1 & 20.1 & 12.3 \\
\hline 27 & 9.4 & 23.2 & 13.1 & 62 & 9.4 & 21.2 & 11.7 & 97 & 9.1 & 19.8 & 12.2 \\
\hline 28 & 10.0 & 23.5 & 14.0 & 63 & 9.3 & 21.6 & 13. 0 & 98 & 9.2 & 19.9 & 12.3 \\
\hline 29 & 9.5 & 23.0 & 13.6 & 64 & 9.5 & 22.0 & 12.0 & 99 & 9.2 & 19.0 & 11.1 \\
\hline 30 & 9.5 & 24.0 & 13.8 & 65 & 9.9 & 22.0 & 13.1 & 100 & 9.5 & 20.5 & 11.8 \\
\hline 31 & 10.0 & 23.1 & 13.0 & 66 & 9.5 & 21.0 & 10.5 & & 9.0 & 20.0 & 11.0 \\
\hline 32 & 9.4 & 22.9 & 13.4 & 67 & 9.3 & 20.9 & 11.7 & Average. & 9.55 & 22.13 & 12.41 \\
\hline 33 & 9.4 & 22.6 & 13.7 & 68 & 9.1 & 20.3 & 12.2 & Greatest. & 10.5 & 27.5 & 13.9 \\
\hline 34 & 9.4 & 23.7 & 12.8 & 69 & 9.8 & 21.1 & 12.2 & Least. . . & 8.5 & 19.0 & 10.6 \\
\hline 35 & 9.6 & 23.5 & 13.0 & 70 & 9.2 & 21.3 & 13.1 & & & & \\
\hline
\end{tabular}


TABLE No. 30.-Measurements of the first generation of Florida-grown Cerion crassilabris from Loggerhead Key Colony L.

\begin{tabular}{|c|c|c|c|c|c|c|c|c|c|c|c|}
\hline \multirow{2}{*}{$\begin{array}{l}\text { Serial } \\
\text { No. }\end{array}$} & \multirow{2}{*}{$\begin{array}{l}\text { No. of } \\
\text { whorls. }\end{array}$} & \multicolumn{2}{|c|}{$\begin{array}{l}\text { Measurements } \\
\text { of shells. }\end{array}$} & \multirow{2}{*}{$\begin{array}{l}\text { Serial } \\
\text { No. }\end{array}$} & \multirow{2}{*}{$\begin{array}{l}\text { No. of } \\
\text { whorls. }\end{array}$} & \multicolumn{2}{|c|}{$\begin{array}{l}\text { Measurements } \\
\text { of shells. }\end{array}$} & \multirow{2}{*}{$\begin{array}{l}\text { Serial } \\
\text { No. }\end{array}$} & \multirow{2}{*}{$\begin{array}{l}\text { No, of } \\
\text { whorls. }\end{array}$} & \multicolumn{2}{|c|}{$\begin{array}{c}\text { Measurements } \\
\text { of shells. }\end{array}$} \\
\hline & & Alt. & Diam. & & & Alt. & Diam. & & & Alt. & Diam. \\
\hline & & $m m$. & $m m$ & & & & & & & & \\
\hline 1 & 9.9 & 22.3 & 11.0 & 15 & 9.4 & 23.3 & 10.6 & 29 & 9.9 & 21.0 & 9.7 \\
\hline 2 & 10.1 & 22,6 & 9.9 & 16 & 9.1 & 21.4 & 10.2 & 30 & 9.6 & 22.0 & 10.6 \\
\hline 3 & 10.0 & 22.8 & 10.8 & 17 & 9.2 & 20.0 & 10.0 & 31 & 9.6 & 23.5 & 10.8 \\
\hline 4 & 9.9 & 22.0 & 9.7 & 18 & 9.3 & 24.2 & 10.9 & 32 & 9.3 & 20.9 & 10.6 \\
\hline 5 & 10.0 & 22.9 & 11.0 & 19 & 8.8 & 20.0 & 10.5 & 33 & 9.0 & 19.2 & 9.9 \\
\hline 6 & 9.0 & 21.9 & 10.3 & 20 & 9.6 & 22.3 & 11.0 & 34 & 9.9 & 21.9 & 10.6 \\
\hline 7 & 9.7 & 22.2 & 10.6 & 21 & 9.1 & 22.1 & 10.3 & 35 & 9.3 & 23.5 & 10.6 \\
\hline 8 & 9.8 & 23.4 & 10.1 & 22 & 9.4 & 22.4 & 10.3 & 36 & 9.5 & 22.9 & 10.6 \\
\hline 9 & 9.8 & 22.8 & 12.3 & 23 & 9.9 & 23.7 & 10.1 & & & & \\
\hline 10 & 10.0 & 23.3 & 10.3 & 24 & 9.4 & 20.9 & 10.0 & Average. & 9.55 & 22.29 & 10.49 \\
\hline 11 & 9.8 & 23.0 & 11.4 & 25 & 9.5 & 21.8 & 9.9 & Greatest. & 10.1 & 25.4 & 12.3 \\
\hline 12 & 9.6 & 23.5 & 10.6 & 26 & 10.1 & 25.4 & 10.6 & Least... & 8.8 & 19.2 & 9.7 \\
\hline 13 & 9.1 & 21.4 & 10.5 & 27 & 9.2 & 21.4 & 10.7 & & & & \\
\hline 14 & 9.6 & 22.3 & 10.2 & 28 & 9.6 & 21.4 & 10.6 & & & & \\
\hline
\end{tabular}

The snails were doing well in May 1916.

In July 1917 no adult specimens of the first generation were located.

In January 1919 we obtained 36 adult and 4 almost adult individuals of the first generation, and many tips were in evidence at the base of tufts of grass. The 36 adult specimens were measured and their measurements are given in table 30 , while the photographs of all the 40 are shown on plate 51. These 40 specimens form the basis of Colony $\mathrm{S}$.

\section{The Loggerhead Key Colony S.}

This consists of 40 specimens of the first generation of Florida-grown Cerion crassilabris. They were planted in the northwest corner of the large meadow in which Cerion uva (Linnæus) is located. The planting is fringed for a great part by bay cedars and the ground contains a good growth of Cyprus brunneus, Sporobolus virginicus, and a scattered growth of cacti. The planting was marked by a stake bearing a tag with the legend: "Cerion, 1919, S."

The measurements of the first generation of Florida-grown Cerion crassilabris fall completely within the range of variations noted for the check series excepting in the case of the least diameter, where the Florida-grown shells show several specimens with the diameter a fraction of a millimeter narrower than in the check series.

A comparison of the figures (plate 51) with the check series will reveal that no appreciable change in outline or sculpture has taken place. We may therefore state that, as in the case of Cerion viaregis and Cerion casablancoe, the changed environment to which we have subjected these specimens has not affected the progeny in any recognizable manner. 


\section{Cerion uva (Linnatus)}

The Loggerhead Key Colony N.

On May 25, 1916, we planted 8,317 of this species which had been gathered by Dr. Ralph Arnold on Curaçao, Netherlands West Indies, in the southeastern end of the large central meadow in the southern end of the island. We first cleared the meadow of the abundant cactus growth. The ground here is largely fringed with bay cedars and covered with a good growth of Sporobolus virginicus and Cyprus brunneus.

From the above-mentioned collection 100 specimens, taken at random, Cat. No. 334725, U. S. N. M., yield the measurements given in table 31 . These specimens are figured on plates 52 and 53 .

In July 1916 large numbers of very small young were observed, but no adult Florida-grown individuals were present.

In January 1919 we found numerous young, but not a single adult Florida-grown shell.

Table No. 31.-Check series of Cerion uva.

\begin{tabular}{|c|c|c|c|c|c|c|c|c|c|c|c|}
\hline \multirow{2}{*}{$\begin{array}{l}\text { Serial } \\
\text { No. }\end{array}$} & \multirow{2}{*}{$\begin{array}{l}\text { No. of } \\
\text { whorls. }\end{array}$} & \multicolumn{2}{|c|}{$\begin{array}{l}\text { Measurements } \\
\text { of shells. }\end{array}$} & \multirow{2}{*}{$\begin{array}{l}\text { Serial } \\
\text { No. }\end{array}$} & \multirow{2}{*}{$\begin{array}{l}\text { No. of } \\
\text { whorls. }\end{array}$} & \multicolumn{2}{|c|}{$\begin{array}{l}\text { Measurements } \\
\text { of shells. }\end{array}$} & \multirow{2}{*}{$\begin{array}{c}\text { Serial } \\
\text { No. }\end{array}$} & \multirow{2}{*}{$\begin{array}{l}\text { No. of } \\
\text { whorls. }\end{array}$} & \multicolumn{2}{|c|}{$\begin{array}{l}\text { Measurements } \\
\text { of shells. }\end{array}$} \\
\hline & & Alt. & Diam. & & & Alt. & Diam. & & & Alt. & Diam. \\
\hline 1 & 12.2 & $\begin{array}{l}m m . \\
22.1\end{array}$ & $\begin{array}{l}m m . \\
10.0\end{array}$ & 36 & 11.1 & $\begin{array}{l}m m . \\
20.5\end{array}$ & $\begin{array}{l}m m . \\
10.6\end{array}$ & 71 & 11.9 & $\begin{array}{l}m m . \\
21.5\end{array}$ & $\begin{array}{r}m m . \\
9.5\end{array}$ \\
\hline 2 & 12.0 & 23.0 & 11.0 & 37 & 11.3 & 19.5 & 10.0 & 72 & 10.8 & 19.0 & 9.5 \\
\hline 3 & 12.1 & 22.0 & 10.1 & 38 & 11.0 & 21.8 & 11.0 & 73 & 11.8 & 20.5 & 10.0 \\
\hline 4 & 13.0 & 23.7 & 11.0 & 39 & 11.0 & 20.5 & 10.0 & 74 & 11.9 & 21.8 & 10.2 \\
\hline 5 & 11.9 & 21.0 & 10.2 & 40 & 12.1 & 23.0 & 10.0 & 75 & 11.0 & 20.0 & 10.2 \\
\hline 6 & 11.0 & 22.5 & 10.0 & 41 & 11.5 & 20.5 & 10.1 & 76 & 11.0 & 21.0 & 10.4 \\
\hline 7 & 11.8 & 20.5 & 9.0 & 42 & 11.7 & 20.3 & 10.0 & 77 & 11.5 & 21.0 & 10.0 \\
\hline 8 & 11.1 & 20.5 & 11.0 & 43 & 11.3 & 21.0 & 11.0 & 78 & 11.0 & 20.1 & 9.1 \\
\hline 9 & 10.0 & 19.1 & 9.5 & 44 & 11.9 & 21.0 & 10.5 & 79 & 11.6 & 20.5 & 9.5 \\
\hline 10 & 11.5 & 21.0 & 10.0 & 45 & 10.5 & 18.1 & 10.0 & 80 & 11.0 & 20.0 & 9.5 \\
\hline 11 & 12.5 & 23.1 & 10.2 & 46 & 11.5 & 21.0 & 10.0 & 81 & 12.5 & 19.8 & 10.5 \\
\hline 12 & 12.5 & 22.5 & 10.1 & 47 & 10.5 & 18.0 & 9.5 & 82 & 11.9 & 21.0 & 10.8 \\
\hline 13 & 11.0 & 19.4 & 10.5 & 48 & 11.5 & 20.5 & 10.2 & 83 & 10.8 & 19.0 & 10.0 \\
\hline 14 & 12.1 & 24.0 & 10.4 & 49 & 11.5 & 21.5 & 10.5 & 84 & 11.9 & 20.4 & 10.0 \\
\hline 15 & 12.5 & 24.0 & 11.0 & 50 & 11.6 & 21.2 & 9.3 & 85 & 11.2 & 20.0 & 10.0 \\
\hline 16 & 10.8 & 18.0 & 10.0 & 51 & 12.0 & 19.0 & 10.0 & 86 & 11.0 & 21.0 & 9.3 \\
\hline 17 & 11.7 & 22.5 & 10.0 & 52 & 12.1 & 21.1 & 10.0 & 57 & 10.9 & 19.7 & 10.0 \\
\hline 18 & 11.1 & 20.2 & 11.0 & 53 & 11.0 & 21.0 & 10.3 & ss & 11.8 & 21.0 & 9.5 \\
\hline 19 & 12.0 & 22.0 & 10.0 & 54 & 11.1 & 22.1 & 10.5 & 89 & 12.5 & 23.0 & 10.5 \\
\hline 20 & 11.0 & 20.0 & 10.2 & 55 & 10.8 & 19.1 & 10.0 & 90 & 12.0 & 20.5 & 9.4 \\
\hline 21 & 10.9 & 18.0 & 9.0 & 56 & 10.9 & 19.8 & 10.1 & 91 & 11.5 & 20.0 & 10.0 \\
\hline 22 & 12.0 & 22.0 & 9.5 & 57 & 11.2 & 21.0 & 10.0 & 92 & 11.3 & 21.0 & 9.5 \\
\hline 23 & 12.8 & 23.1 & 9.9 & 58 & 11.9 & 21.9 & 9.9 & 93 & 11.9 & 21.0 & 9.0 \\
\hline 24 & 11.9 & 21.5 & 11.0 & 59 & 11.6 & 21.5 & 9.1 & 94 & 11.0 & 20.0 & 10.3 \\
\hline 25 & 11.9 & 22.9 & 9.4 & 60 & 11.0 & 20.0 & 10.0 & 95 & 11.0 & 20.0 & 10.3 \\
\hline 26 & 10.0 & 18.8 & 10.4 & 61 & 11.9 & 21.6 & 10.0 & 96 & 11.8 & 20.5 & 10.0 \\
\hline 27 & 12.0 & 21.0 & 9.0 & 62 & 10.8 & 19.0 & 9.3 & 97 & 10.9 & 19.6 & 9.5 \\
\hline 28 & 12.0 & 23.0 & 11.6 & 63 & 11.5 & 22.0 & 10.0 & 98 & 12.5 & 22.6 & 9.6 \\
\hline 29 & 12.2 & 23.0 & 10.0 & 64 & 10.7 & 20.0 & 9.0 & 99 & 11.8 & 20.5 & 9.5 \\
\hline 30 & 12.8 & 22.0 & 10.0 & 65 & 11.3 & 20.6 & 10.0 & 100 & 10.9 & 18.0 & 10.0 \\
\hline 31 & 11.9 & 21.0 & 10.5 & 66 & 11.2 & 20.4 & 10.5 & & & & \\
\hline 32 & 11.9 & 23.0 & 11.0 & 67 & 10.7 & 19.0 & 9.9 & Average. & 11.5 & 20.85 & 10.04 \\
\hline 33 & 10.9 & 19.1 & 10.5 & 68 & 10.7 & 20.0 & 10.0 & Greatest. & 13.0 & 24.0 & 11.6 \\
\hline 34 & 11.0 & 20.5 & 11.0 & 69 & 11.5 & 21.0 & 9.5 & Least. . & 10.0 & 18.0 & 9.0 \\
\hline 35 & 11.9 & 21.2 & 10.7 & 70 & 11.5 & 21.5 & 10.0 & & & & \\
\hline
\end{tabular}




\section{Cerion incanum (Binney) $\times$ Cerion viaregis Bartsch.}

I am sure that all naturalists who have prepared monographs upon large groups of animals have at times been puzzled how to treat systematically and how to account for some of the remarkably variable species which one occasionally finds. It usually happens that in a large genus almost all the forms are clearly defined and easily recognized specifically and there is never a question as to which species a given individual belongs. Now and then, however, one finds a group the members of which are readily recognized as closely related through some characteristic feature in spite of the fact that scarcely two individuals appear to be alike and that some of the extremes of these variants, were their character fixed, would demand a place in a different subgenus from that to which the norm of the group belongs (e.g., Odostomia (Evalea) virginalis Carpenter, from the West Coast of America). Usually this state of affairs is accompanied by the production of a large number of individuals; in fact, these variable forms are usually the dominant element in the region. Not only that, but as a rule we find that such forms are not confined to one faunal area, but appear to be able to extend their range over one or more of the adjacent areas. Organisms presenting such conditions have been said to be in a state of flux. It has been held by some that this variability is an expression of an effort on the part of a species to adjust itself to changing or changed environmental conditions, which, for the time being, affect it adversely. The followers of this hypothesis conceive that the organism, adversely struggling, is putting out an endless array of feelers in the hope of finding a better way or better ways for continued existence. This hypothesis, while it may be true in some cases, does not seem to obtain in the variable forms which have come under my observation, for it scarcely seems possible that the numerically and apparently physically dominant and most widely distributed form of a group in a certain region should be the one least suited to the environment in which it is existing. Prior to this year I was more and more inclined to the belief that we might possibly find that these very abundant and variable forms might represent new ingressions into a faunal area in which conditions for their existence were optimum to an unusual degree, where the normal death rate, due possibly to an absence of natural enemies, might be reduced, and where all the factors involved were inclined to favor the new arrival to the utmost, and that these factors and the necessarily reduced in-breeding might be responsible for the loosening of specific bounds and the producing of variants which, in the course of time, might result in a state of flux.

Our Cerion experiments on Newfound Harbor Key, however, throw a new light upon the case, for here we have produced a state of flux by cross-breeding. There is no question that if we did not know the true inwardness of the Cerion complex as it exists at the present time in our 
colony upon this key, we would treat the material as we have treated such assemblages in the past; that is, as a very variable species. It therefore seems proper to assume that the converse should receive an equally favorable consideration, for it seems fair to believe that further breeding experiments will prove that such complexes are the product of cross-breeding.

The two species which have crossed here are very remotely related as can be readily seen by a comparison of plates $7,8,9$, which represent the check series of Cerion viaregis from Bastian Point, Andros, and plates 54,55,56, which represent a check series of Cerion incanumCat. No. 334726, U. S. N. M.-from Porgee Key, Florida. The last-mentioned species is known to inhabit many of the keys from Virginia Key southwestward to the Marquesas Keys. A comparison of the anatomic structures shows even more striking characters of diversity, as shown on plates 1,5 , and 6 , and discussed on pages 7 to 13 of this paper. The fact is, that it is very surprising that organisms presenting such great differences in organization should be able to cross at all, and it is still more remarkable that they should have produced fertile crosses. In this connection it should be recalled that our efforts to effect a cross between the Bahaman Cerion casablanca and Cerion viaregis proved unsuccessful.

The offspring produced by this crossing show a remarkable range in variation, as can be readily seen by an examination of the 125 figures on plates 57,58 , and 59. This variation not only includes forms which appear near typical Cerion incanum and near typical Cerion viaregis and all grades of intermediates between these, but also forms that so closely resemble species of the Bahama mottled Cerion of the Cerion martensi group, that one not knowing their origin would unhesitatingly refer them to species of this complex occupying restricted areas in the Bahamas. Our crossing has evidently called to the surface submerged mottled Cerion strains present in Cerion viaregis and probably present in all the members of the complex that has been passing under the name of Cerion glans.

The mixed elements vary in shape from the slender Cerion incanum type to the more or less cylindric Cerion viaregis, but a few of the specimens diverge entirely from this shape and assume the outline of the mottled Bahama Cerions. In ribbing they vary from the almost smooth Cerion incanum to the strongly costate Cerion viaregis. Forms having the shape of Cerion incanum may have the sculpture of Cerion viaregis, or the reverse may obtain. It should be mentioned here that the ribbing in the Bahama mottled Cerion falls between Cerion incanum and Cerion viaregis as far as strength goes, usually being a little nearer Cerion incanum in this respect. In coloration these specimens range from the color of Cerion incanum, which is white or sometimes finely vermiculated, to variously mottled, blotched, streaked 
TABLE No. 32.-Check series of Cerion incanum.

\begin{tabular}{|c|c|c|c|c|c|c|c|c|c|c|c|}
\hline \multirow{2}{*}{$\begin{array}{l}\text { Serial } \\
\text { No. }\end{array}$} & \multirow{2}{*}{$\begin{array}{l}\text { No. of } \\
\text { whorls. }\end{array}$} & \multicolumn{2}{|c|}{$\begin{array}{l}\text { Measurements } \\
\text { of shells. }\end{array}$} & \multirow{2}{*}{$\begin{array}{l}\text { Serial } \\
\text { No. }\end{array}$} & \multirow{2}{*}{$\begin{array}{l}\text { No. of } \\
\text { whorls. }\end{array}$} & \multicolumn{2}{|c|}{$\begin{array}{l}\text { Measurements } \\
\text { of shells. }\end{array}$} & \multirow{2}{*}{$\begin{array}{l}\text { Serial } \\
\text { No. }\end{array}$} & \multirow{2}{*}{$\begin{array}{l}\text { No. of } \\
\text { whorls. }\end{array}$} & \multicolumn{2}{|c|}{$\begin{array}{l}\text { Measurements } \\
\text { of shells. }\end{array}$} \\
\hline & & Alt. & Diam. & & & Alt. & Diam. & & & Alt. & Diam. \\
\hline 1 & 12.4 & $\begin{array}{l}m m . \\
30.8\end{array}$ & $\begin{array}{l}m m . \\
13.8\end{array}$ & 36 & 11.8 & $\begin{array}{l}m m . \\
28.3\end{array}$ & $\begin{array}{l}m m . \\
12.7\end{array}$ & 71 & 112 & $m m$. & $m m$. \\
\hline 2 & 11.5 & 28.2 & 13.6 & 37 & 11.8 & 28.7 & 13.0 & 72 & 10.6 & $\begin{array}{l}20.0 \\
22.8\end{array}$ & 12.0 \\
\hline 3 & 11.5 & 26.6 & 12.2 & 38 & 11.3 & 27.2 & 12.0 & 73 & 11.0 & 25.5 & 12.3 \\
\hline 4 & 11.2 & 27.2 & 12.6 & 39 & 11.5 & 27.5 & 12.5 & 74 & 11.1 & 26.1 & 14.4 \\
\hline 5 & 10.7 & 23.8 & 14.0 & 40 & 11.6 & 26.7 & 12.1 & 75 & 10.9 & 25.0 & 13.2 \\
\hline 6 & 10.2 & 22.0 & 12.0 & 41 & 10.9 & 25.0 & 13.1 & 76 & 10.8 & 24.4 & 13.9 \\
\hline 7 & 11.9 & 28.4 & 13.6 & 42 & 11.0 & 25.9 & 12.8 & 77 & 10.6 & 24.8 & 13.2 \\
\hline 8 & 11.5 & 27.3 & 12.5 & 43 & 10.8 & 24.9 & 13.7 & 78 & 11.1 & 25.1 & 12.5 \\
\hline 9 & 11.3 & 28.6 & 12.9 & 44 & 11.0 & 26.1 & 13.2 & 79 & 10.8 & 25.2 & 12.5 \\
\hline 10 & 11.4 & 26.6 & 12.2 & 45 & 10.8 & 24.0 & 13.2 & 80 & 10.9 & 26.0 & 13.2 \\
\hline 11 & 11.4 & 28.8 & 13.4 & 46 & 11.4 & 26.8 & 14. & 81 & 11.1 & 25.0 & 12.8 \\
\hline 12 & 11.5 & 28.8 & 13.3 & 47 & 11.6 & 26.8 & 13.0 & 82 & 10.6 & 23.3 & 13.5 \\
\hline 13 & 11.5 & 27.2 & 13.0 & 48 & 11.5 & 26.2 & 13. & 83 & 11.2 & 23.5 & 11.7 \\
\hline 14 & 11.3 & 26.5 & 12.2 & 49 & 10.5 & 22.6 & 12 . & 84 & 11.3 & 23.9 & 13.2 \\
\hline 15 & 11.9 & 26.8 & 13.6 & 50 & 11.6 & 26.2 & 13. & 85 & 11.2 & 24.4 & 12.2 \\
\hline 16 & 12.0 & 27.8 & 13.2 & 51 & 11. & 27.2 & 13 & 86 & 11. & 25.0 & 13.2 \\
\hline 17 & 11.2 & 26.5 & 13.6 & 52 & 11.4 & 25.9 & 12. & 87 & 10.5 & 23.9 & 13.2 \\
\hline 18 & 11.1 & 26.3 & 12.4 & 53 & 10.8 & 25.0 & 12 & 88 & 10.2 & 23.6 & 13.0 \\
\hline 19 & 11.1 & 23.1 & 11.6 & 54 & 11.2 & 27.6 & 13. & 89 & 11.1 & 23.3 & 12.3 \\
\hline 20 & 11.8 & 26.9 & 12.9 & 55 & 10.4 & 25.0 & 12 & 90 & 11 & 24.4 & 13.1 \\
\hline 21 & 11.5 & 26.2 & 13.8 & 56 & 11.1 & 25.9 & 13. & 91 & 11.0 & 24.1 & 12.7 \\
\hline 22 & 11.9 & 28.5 & 12.5 & 57 & 10.8 & 25.9 & 12. & 92 & 11.0 & 24.0 & 12.9 \\
\hline 23 & 10.6 & 25.2 & 13. & 58 & 11. & 27 . & & 93 & 10 & 24.2 & 13.2 \\
\hline 24 & 10.0 & 22.8 & 11.5 & 59 & 10.9 & 23.4 & 12.2 & 94 & 10 & 25.0 & 13.2 \\
\hline 25 & 11.4 & 26.5 & 12.8 & 60 & 11 & 25.3 & & 95 & 10 & 23.0 & 11.5 \\
\hline 26 & 11.3 & 25.7 & 12.0 & 61 & 10.6 & 24.0 & 12 & 96 & 10 & 23.0 & 11.5 \\
\hline 27 & 11.5 & 28.0 & 13.3 & 62 & 10.7 & 23.1 & 12 & 97 & 10 & 24.2 & 12.3 \\
\hline 28 & 10.9 & 25.0 & 12.5 & 63 & 10.5 & 23.9 & 13.5 & 98 & 10 & 23.4 & 11.6 \\
\hline 29 & 11.1 & 26.4 & 13.0 & 64 & 10.9 & 24.8 & 13.0 & 99 & 10.5 & 24.2 & 14.0 \\
\hline 30 & 10.4 & 25.0 & 13.0 & 65 & 11.0 & 26.1 & 13.3 & 100 & 10.5 & 23.0 & 12.1 \\
\hline 31 & 11.0 & 24.8 & 12.7 & 66 & 11.0 & 24.9 & 13.5 & & & & \\
\hline 32 & 11.1 & 25.5 & 12.0 & 67 & 11.6 & 27.0 & 12.6 & Average. & 11.09 & 25.45 & 12.83 \\
\hline 33 & 10.9 & 22.5 & 11.6 & 68 & 10.5 & 23.6 & 12.0 & Greatest. & 12.4 & 30.8 & 14.4 \\
\hline 34 & 11.2 & 23.8 & 12.1 & 69 & 11.8 & 23.8 & 11.8 & Least. . . & 10.0 & 22.0 & 11.5 \\
\hline 35 & 10.9 & 25.1 & 12.0 & 70 & 11.0 & 25.0 & 12.9 & & & & \\
\hline
\end{tabular}

fulgurate with various shades of brown. Specimens with the outline of typical Cerion incanum and Cerion viaregis may be strongly mottled and splashed with brown. Sometimes a specimen having the outline, sculpture, and external coloration of Cerion incanum shows the interior coloration of typical Cerion viaregis, and vice versa.

Tables 32 and 33 give measurements of the check series of Cerion incanum and of the cross between Cerion viaregis and Cerion incanum, while table 34 gives a comparison of the summaries of Cerion viaregis, Cerion incanum, and Cerion viaregis $\times$ Cerion incanum.

Table 34 shows that the cross between Cerion incanum and Cerion viaregis stands between the parent species, as far as number of whorls and measurements of altitude and diameter are concerned. The specimens figured on plates 57,58 , and 59 , are now in my conservatory at Washington, where an attempt is being made to simulate the Florida environmental conditions, as far as it is possible to do so. We have 
TABLE No. 33.-Cerion viaregis Bartsch $\times$ Cerion incanum Binney.

\begin{tabular}{|c|c|c|c|c|c|c|c|c|c|c|c|}
\hline \multirow{2}{*}{$\begin{array}{l}\text { Serial } \\
\text { No. }\end{array}$} & \multirow{2}{*}{$\begin{array}{l}\text { No. of } \\
\text { whorls. }\end{array}$} & \multicolumn{2}{|c|}{$\begin{array}{l}\text { Measurements } \\
\text { of shells. }\end{array}$} & \multirow{2}{*}{$\begin{array}{l}\text { Serial } \\
\text { No. }\end{array}$} & \multirow{2}{*}{$\begin{array}{l}\text { No. of } \\
\text { whorls. }\end{array}$} & \multicolumn{2}{|c|}{$\begin{array}{l}\text { Measurements } \\
\text { of shells. }\end{array}$} & \multirow{2}{*}{$\begin{array}{l}\text { Serial } \\
\text { No. }\end{array}$} & \multirow{2}{*}{$\begin{array}{l}\text { No. of } \\
\text { whorls. }\end{array}$} & \multicolumn{2}{|c|}{$\begin{array}{l}\text { Measurements } \\
\text { of shells. }\end{array}$} \\
\hline & & Alt. & Diam. & & & Alt. & Diam. & & & Alt. & Diam. \\
\hline & & $m m$. & $m m$. & & & $m m$. & $m m$. & 87 & 10.3 & $\begin{array}{l}m m . \\
22.9\end{array}$ & $\mathrm{~mm}$. \\
\hline 1 & 10.1 & 24.5 & $\begin{array}{l}11.8 \\
11.8\end{array}$ & $\begin{array}{l}44 \\
45\end{array}$ & $\begin{array}{l}11.1 \\
10.1\end{array}$ & $\begin{array}{l}25.0 \\
22.3\end{array}$ & $\begin{array}{l}12.5 \\
11.1\end{array}$ & $\begin{array}{l}87 \\
88\end{array}$ & $\begin{array}{l}10.3 \\
10.4\end{array}$ & $\begin{array}{l}22.9 \\
22.9\end{array}$ & $\begin{array}{l}11.1 \\
10.9\end{array}$ \\
\hline $\begin{array}{l}2 \\
3\end{array}$ & $\begin{array}{l}10.3 \\
11.1\end{array}$ & $\begin{array}{l}23.7 \\
24.5\end{array}$ & $\begin{array}{l}11.8 \\
10.8\end{array}$ & $\begin{array}{l}70 \\
46\end{array}$ & broken & lip. & & 89 & 10.2 & 21.8 & 11.1 \\
\hline 4 & 10.4 & 23.3 & 11.0 & 47 & 10.4 & 20.5 & 10.4 & 90 & 10.0 & 20.0 & 10.6 \\
\hline 5 & 10.5 & 24.2 & 10.8 & 48 & 10.5 & 22.2 & 11.7 & 91 & young. & & \\
\hline 6 & 10.4 & 24.0 & 10.3 & 49 & 11.2 & 24.5 & 10.5 & 92 & broken & lip. & \\
\hline 7 & 11.3 & 25.9 & 12.1 & 50 & 11.2 & 24.4 & 12.1 & 93 & broken & lip. & \\
\hline 8 & 10.1 & 21.1 & 11.0 & 51 & 10.3 & 23.9 & 12.3 & 94 & 10.2 & 22.2 & 10.7 \\
\hline 9 & 10.6 & 23.5 & 10.8 & 52 & 10.5 & 21.7 & 11.2 & 95 & 10.3 & 21.6 & 11.9 \\
\hline 10 & 10.2 & 23.8 & 11.3 & 53 & 9.6 & 21.7 & 10.2 & 96 & 11.2 & 23.1 & 12.8 \\
\hline 11 & broken & lip. & & 54 & 10.4 & 22.8 & 11.2 & 97 & 9.3 & 20.9 & 11.4 \\
\hline 12 & 10.3 & 22.2 & 11.1 & 55 & 10.5 & 20.7 & 11.4 & 98 & broken & lip. & \\
\hline 13 & broken & lip. & & 56 & broken & lip-im & mature. & 99 & 10.9 & 23.1 & 11.1 \\
\hline 14 & 10.2 & 22.1 & 11.4 & 57 & 11.0 & 24.9 & 11.7 & 100 & young. & & \\
\hline 15 & 10.4 & 22.2 & 10.0 & 58 & 11.3 & 24.5 & 11.1 & 101 & 10.3 & 21.4 & 11.0 \\
\hline 16 & 10.3 & 20.9 & 11.0 & 59 & 10.7 & 23.2 & 11.6 & 102 & young. & & \\
\hline 17 & 10.2 & 22.1 & 10.7 & 60 & 11.1 & 23.9 & 11.6 & 103 & young. & & \\
\hline 18 & 10.3 & 22.6 & 10.2 & 61 & 10.2 & 22.4 & 11.0 & 104 & broken & lip. & \\
\hline 19 & 10.3 & 22.4 & 9.5 & 62 & 11.9 & 24.5 & 11.0 & 105 & 10.8 & 23.1 & 11.9 \\
\hline 20 & 10.3 & 22.7 & 11.0 & 63 & 9.6 & 20.5 & 11.3 & 106 & 10.3 & 22.6 & 12.5 \\
\hline 21 & 10.4 & 23.3 & 10.2 & 64 & 11.3 & 24.2 & 12.2 & 107 & 11.0 & 23.5 & 11.3 \\
\hline 22 & 11.0 & 24.0 & 11.2 & 65 & 11.0 & 23.7 & 12.6 & 108 & 11.3 & 24.0 & 10.3 \\
\hline 23 & 11.2 & 24.9 & 11.2 & 66 & 11.0 & 24.8 & 12.2 & 109 & 10.5 & 21.4 & 10.9 \\
\hline 24 & 11.3 & 24.2 & 12.0 & 67 & broken & lip. & & 110 & 10.0 & 21.1 & 10.4 \\
\hline 25 & 10.5 & 22.8 & 11.7 & 68 & broken & lip. & & 111 & young. & & \\
\hline 26 & 11.2 & 24.0 & 11.6 & 69 & 10.6 & 21.9 & 10.9 & 112 & young. & & \\
\hline 27 & immat & ure. & & 70 & 10.3 & 22.4 & 9.5 & 113 & 10.6 & 21.8 & 10.6 \\
\hline 28 & 10.7 & 21.8 & 10.9 & 71 & 11.0 & 24.1 & 11.8 & 114 & 10.4 & 21.8 & 10.5 \\
\hline 29 & 10.4 & 22.1 & 11.7 & 72 & 11.6 & 28.4 & 13.4 & 115 & 10.7 & 22.7 & 12.4 \\
\hline 30 & 10.4 & 22.0 & 11.7 & 73 & 10.8 & 24.8 & 12.8 & 116 & 11.2 & 21.2 & 11.7 \\
\hline 31 & immat & ure. & & 74 & 10.4 & 22.7 & 10.0 & 117 & 11.4 & 23.3 & 12.9 \\
\hline 32 & 9.6 & 19.5 & 9.4 & 75 & 11.0 & 23.4 & 11.2 & 118 & 10.2 & 22.0 & 11.9 \\
\hline 33 & 10.3 & 21.7 & 12.1 & 76 & 11.2 & 25.0 & 13.0 & 119 & 10.4 & 21.2 & 11.0 \\
\hline 34 & 10.6 & 22.8 & 11.2 & 77 & young. & & & 120 & 10.8 & 23.6 & 11.0 \\
\hline 35 & 10.1 & 22.9 & 11.9 & 78 & 10.5 & 21.6 & 12.3 & 121 & 10.7 & 23.0 & 11.1 \\
\hline 36 & 10.6 & 23.8 & 11.9 & 79 & 10.8 & 22.8 & 10.3 & 122 & 10.7 & 21.0 & 10.9 \\
\hline 37 & 10.3 & 23.3 & 11.0 & 80 & 10.1 & 22.0 & 10.7 & 123 & 10.8 & 24.1 & 12.2 \\
\hline 38 & 10.5 & 25.0 & 11.7 & 81 & 11.1 & 23.1 & 10.7 & 124 & young. & & \\
\hline 39 & 10.5 & 22.3 & 11.0 & 82 & 9.4 & 19.1 & 10.6 & 125 & young. & & \\
\hline 40 & 10.3 & 23.5 & 11.7 & 83 & 11.1 & 23.6 & 10.9 & & & & \\
\hline 41 & 10.4 & 24.1 & 12.1 & 84 & 10.0 & 19.2 & 10.0 & Average. & 10.57 & 22.85 & 11.27 \\
\hline 42 & 10.5 & 22.1 & 11.3 & 85 & 10.1 & 20.3 & 9.4 & Greatest. & 11.9 & 28.4 & 13.4 \\
\hline 43 & 11.6 & 26.5 & 12.7 & 86 & 10.4 & 22.6 & 11.1 & Least. . & 9.3 & 19.1 & 9.4 \\
\hline
\end{tabular}

Table No. 34.

\begin{tabular}{|c|c|c|c|c|c|c|c|c|c|}
\hline \multirow{2}{*}{ Name. } & \multicolumn{3}{|c|}{ Averages. } & \multicolumn{3}{|c|}{ Greatest. } & \multicolumn{3}{|c|}{ Least. } \\
\hline & $\begin{array}{l}\text { No. of } \\
\text { whorls. }\end{array}$ & $\begin{array}{l}\text { Alti- } \\
\text { tude. }\end{array}$ & $\begin{array}{l}\text { Greater } \\
\text { diameter. }\end{array}$ & $\begin{array}{l}\text { No. of } \\
\text { whorls. }\end{array}$ & $\begin{array}{l}\text { Alti- } \\
\text { tude. }\end{array}$ & $\begin{array}{l}\text { Greater } \\
\text { diameter. }\end{array}$ & $\begin{array}{l}\text { No. of } \\
\text { whorls. }\end{array}$ & $\begin{array}{l}\text { Alti- } \\
\text { tude. }\end{array}$ & $\begin{array}{l}\text { Greater } \\
\text { diameter. }\end{array}$ \\
\hline Cerion viaregis... & 10.08 & 22.56 & 21.13 & 11.00 & 27.00 & 12.70 & 9.10 & 19.00 & 9.00 \\
\hline C. viaregis $\times$ C. incanum & 10.57 & 22.85 & 11.27 & 11.90 & 28.40 & 13.40 & 9.30 & 19.10 & 9.40 \\
\hline Cerion incanum.... & 11.09 & 25.45 & 12.84 & 12.40 & 30.80 & 14.40 & 10.00 & 22.00 & 11.50 \\
\hline
\end{tabular}


even obtained Florida key soil and plants in the hope of establishing the microflora upon which these forms seem to thrive and all efforts will be made to keep moisture and temperature conditions as near as possible to the Florida standard. In this conservatory we have segregated pairs as nearly alike as possible, in order to determine, should we be successful in breeding these forms, if a fixation of characters might be effected and new species thus produced.

In the light of the foregoing results the whole Cerion problem assumes a new aspect. One naturally wonders how this enormously diversified group may have been produced and from what source it was derived. To-day we know members of the genus from the Bahamas, where they are the dominant element in the molluscan fauna. It is here that the genus finds its greatest development. From the Bahamas they extend westward over the Florida Keys and probably over part of the southern tip of the mainland of Florida, then south over Cuba and its islets, the Isle of Pines, the Caymans, Haiti, Porto Rico, and the Virgin Islands. They appear to be absent from Jamaica and the Windward and Leeward group, but we again find them represented in Curaçao by Cerion $u v a$, and Cerion antoni (Küster) has been described from Berbice, British Guiana.

It is unfortunate that the geological history of the group is so incomplete. At present the oldest-known member of the genus, Cerion anodonta Dall, comes from the Oligocene silex beds at Tampa, Florida. None of the Bahama fossil forms known are older than the Pliocene. The absence of records from the Windward and Leeward Islands leaves a gap in our chain connecting with South America, the cradle of most of our West Indian land shells. Of course it is possible that Cerion, too, may have had its beginning in South America, for our knowledge of the derivation and distribution of other groups, slight as it seems, and the presence of Cerion antoni (Küster) in British Guiana and of the stranded Cerion uva in Curaçao, offer strong suggestions that this may have been the case.

In a former communication* I pointed out that Cerions could stand 4 days of complete immersion in sea-water. This renders it probable that they may have been transported on driftwood. Their occurrence in lowland regions and their habit of affixing themselves to stumps and dead wood during estivation render them especially adapted for this method of distribution. A hurricane might flood a region occupied by Cerions and set adrift 100 or more on a single log, which, after floating for an indefinite period, might effect lodgment in a favorable habitation and thus start a new colony. If this is the chief method for longdistance progression, we would have to look to our ocean currents as the determining factor of the direction of Cerion movement. This, of

*Year Book No. 11, Carnegie Institution of Washington, 1912, p. 131. 
course, points to a northward movement, and I would not be at all surprised, therefore, if fossil ancestors were found in South America, and even fossil members in the chain of the Windward and Leeward Islands. The elements of this chain have at various times been subjected to subsidence which may have eliminated the living members. If South America is also the cradle of the Cerions, then the first migration must have taken place at an exceedingly early period-at all events, prior to Oligocene times, for at that period we find them well established in the silex beds at Tampa, Florida.

The Bahama Cerions offer an interesting field for speculation. Here we find to-day thousands of colonies, sometimes occupying slight elevations separated by slight depressions occupied by shallow water. It appears now that these colonies are perfectly good species.

Our experiments on Newfound Harbor Key indicate an unusual fertility on the part of the cross between Cerion viaregis and Cerion incanum, and one wonders if such a crossing, where fertile offspring are produced, may not have a rejuvenating effect upon such a hybrid. As stated before, wherever I have noted a state of flux among mollusks, whether land, fresh-water, or marine, it was found that with this condition there was always associated a very large production of individuals. This is true to such an extent that the fluxed element has always been the dominant form of the group to which it belongs in the region occupied by it. This would suggest that crossing has an energizing effect which seems to enable the new product to surpass its associated congeneric forms in the production of offspring.

It seems possible that during the glacial period, when the low state of water in the sea united the numerous keys which constitute the Bahama Archipelago into one land mass, forms separated by sea barriers during Pliocene times were enabled to come together and to cross. It is not at all improbable that this crossing may have resulted in an efflorescence of new forms which may have swarmed over all the shores where we now find the Cerion glans group and probably other groups represented. The close of the glacial period, returning the water to the sea, again split up the region into numerous islands and promontories where the ancestors of the Cerions of to-day were stranded in colonies and where inbreeding gradually eliminated diverse characters, eventually resulting in the more or less homogeneous expression which we now find in each colony. 


\section{EXPLANATION OF PLATES.}

Plate 1. Cerion incanum (Binney).

Plate 2. Cerion casablance Bartsch.

Plate 3. Cerion uva (Linnæus).

Plate 4. Cerion crassilabris ("Shuttleworth" Sowerby).

Plate 5. Cerion viaregis Bartsch.

FIG. 1, plates 1-5. Central nervous system, posterior aspect.
a. g. Abdominal ganglion.
a. n. Abdominal nerve.
b. c. Buccal commissure.
b. v. Blood-vessel.
c. b. u. Left cerebro-buccal commissure.
c. g. Right cerebral ganglion.
c. m. Cerebral commissure.
c. pe. c. Right cerebro-pedal commissure.
c. pl. c. Right cerebro-pleurgl commaissure
c. r. n. Right cephalic retractor nerve.
m. n. Mantle nerves.
o. n. Right optic nerve.
pe. g. pedal ganglion.
r. pl. g. Right pleural ganglion.
r. pl. g. g. Right pleural ganglion.
c. pl. c. Right cerebro-pleural commissure. $\quad$ t. $\mathbf{n}$ Right tentacular nerve.

Fra. 2, plates 1-5. Pallial organs from ventral side.
i. Auricle.
i. Intestine.
p. v. Pulmonary vein.
u.

Fia. 3, plates 1-5. Anterior termination of buccal retractor muscle.
1.
Left branch.
Right branch.
r. r. Radular retractor.

FIG. 4, plates 1-5. Genital system, from dorsal side.
a. a. Albumen gland.
f. g. Flagellum.
p. Penis.
h. d. Hermaphroditic duct.
h. g. Hermaphroditic gland.
o. r. Ocular retractor.
r. m. Penis retractor
B. p. d. Spermathecs.
ov. d. Oviduct.
v. Vagina.
v. d. Vas deferens.
v. r. Vaginal retractor.

Frg. 5, plates 1-5. Jaw.

Frg. 6, plates 1-5. Radula.

$\begin{array}{llll}\text { r. } & \text { Rachidian tooth. } & 10 . & \text { 10th marginal tooth. } \\ \text { 1. } & \text { 1st lateral tooth. } & 12 . & \text { 12th marginal tooth. } \\ \text { 4. } & \text { 4th lateral tooth. } & 13 . & \text { 13th marginal tooth. } \\ \text { 6. } & \text { 6th lateral tooth. } & 16 . & \text { 16th marginal tooth. } \\ \text { 7. } & \text { 7th lateral tooth. } & 18 . & \text { 18th marginal tooth. }\end{array}$

Plate 6. Cerion incanum (Binney) and Cerion viaregis Bartsch.

FIG. 1. Alimentary tract of Cerion incanum from dorsal side.

Fig. 2. Musculature of Cerion incanum, uncoiled.

Fig. 3. Atrium of Cerion incanum, opened to show fleshy protuberance and fleshy ribs.

FIa. 4. Side view of central nervous system of Cerion viaregis.

$\begin{array}{ll}\text { a. } & \text { Anus. } \\ \text { ar. } & \text { Esophageal nerve ring. } \\ \text { b. d. } & \text { Bile ducts. } \\ \text { b. g. } & \text { Right bucol ganglion. } \\ \text { b. m. } & \text { Buccal mass. } \\ \text { b. r. } & \text { Buccal retractor muscle. } \\ \text { c. } & \text { Columellar muscle. } \\ \text { c. b. c. } & \text { Right cerebro-buccal commissure. } \\ \text { c. g. } & \text { Right cerebral ganglion. } \\ \text { c. pe. c. } & \text { Right cerebro-pedal commigsure. } \\ \text { c. pl. c. } & \text { Right cerebro pleural commissure. } \\ \text { int. } & \text { Intestine. } \\ \text { l. c. r. } & \text { Left cephalic retractor. } \\ \text { l. pl. g. } & \text { Left pleural ganglion. } \\ \text { m. } & \text { Mouth. } \\ \text { m. u. } & \text { Mantle nerves. } \\ \text { o.. } & \text { Esophagus. }\end{array}$

$\begin{array}{ll}\text { o. r. } & \text { Ocular retractora. } \\ \text { p. } & \text { Penis. } \\ \text { pl. pe. c. } & \text { Right pleuro-pedal commigsure. } \\ \text { p. n. } & \text { Right pedal nerves. } \\ \text { r. c. r. } & \text { Right cephalic retractor. } \\ \text { r. po.g. } & \text { Right pedal ganglion. } \\ \text { r. pl. g. } & \text { Right pleural ganglion. } \\ \text { s. d. } & \text { Salivary ducts. } \\ \text { o. g. } & \text { Salivary gland. } \\ \text { o. n. } & \text { Right aensory nerve. } \\ \text { ot. } & \text { Stomach. } \\ \text { t. n. } & \text { Right tentacular nerve. } \\ \text { t. r. } & \text { Tentacular retractors. } \\ \text { v. r. } & \text { Vaginal retractor. } \\ \text { u. r. pl. g. Upper right pleural ganglion. } \\ \text { v. }\end{array}$




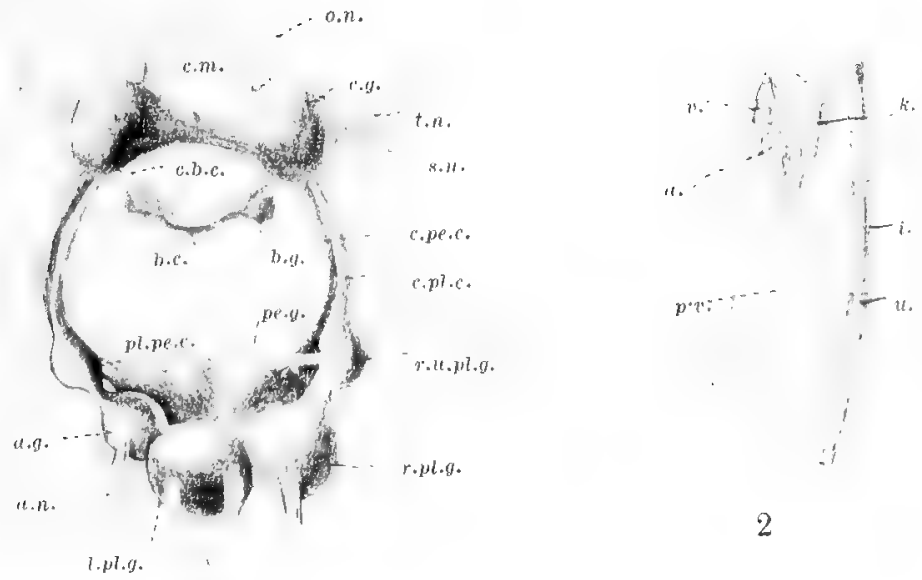

m.n.

1

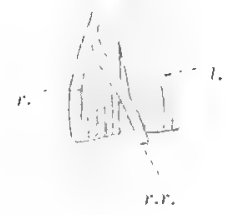

3

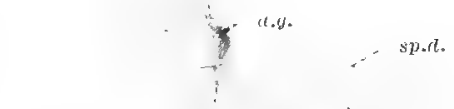

5
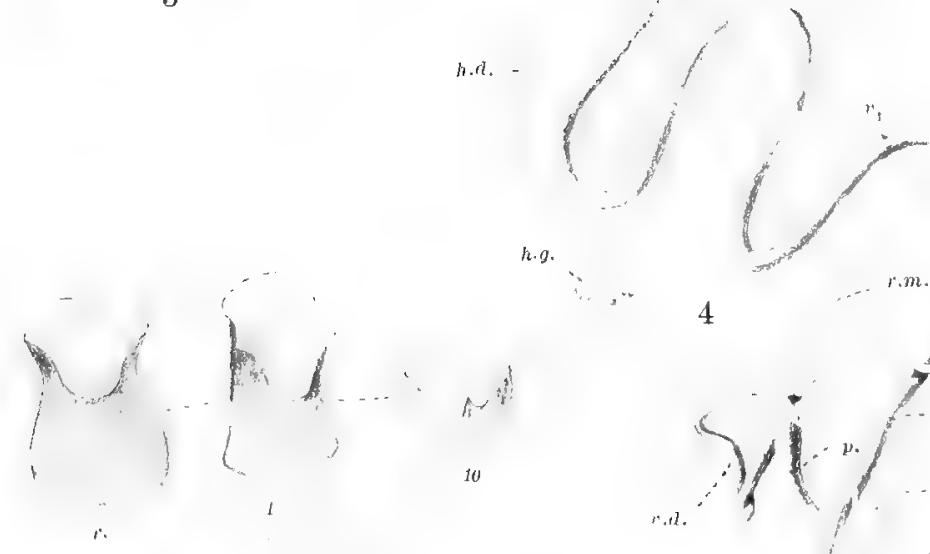

18

6

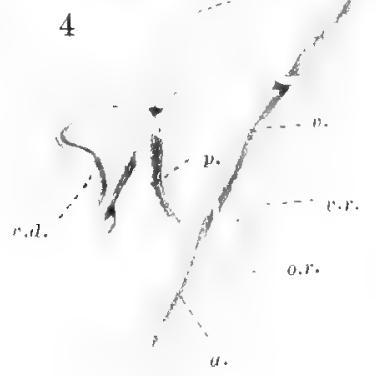

HELIOTYPE CO. BOSTON

Cerion incanum (Binney). 



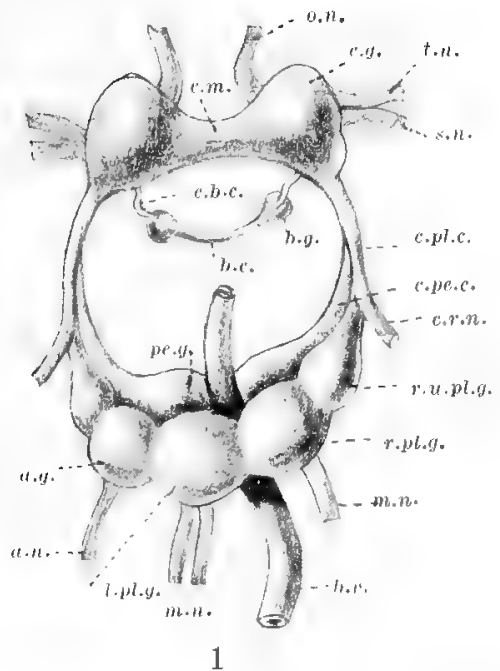

1
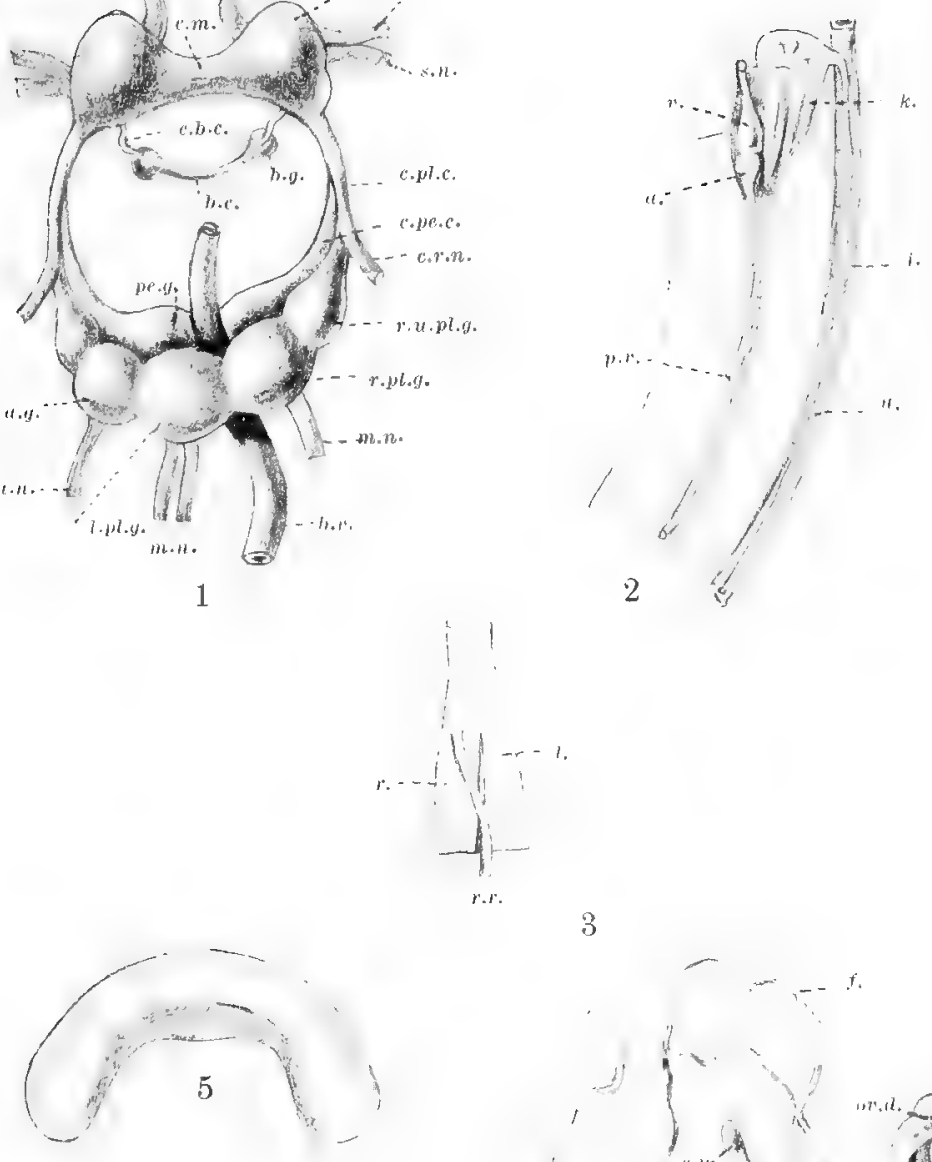

3
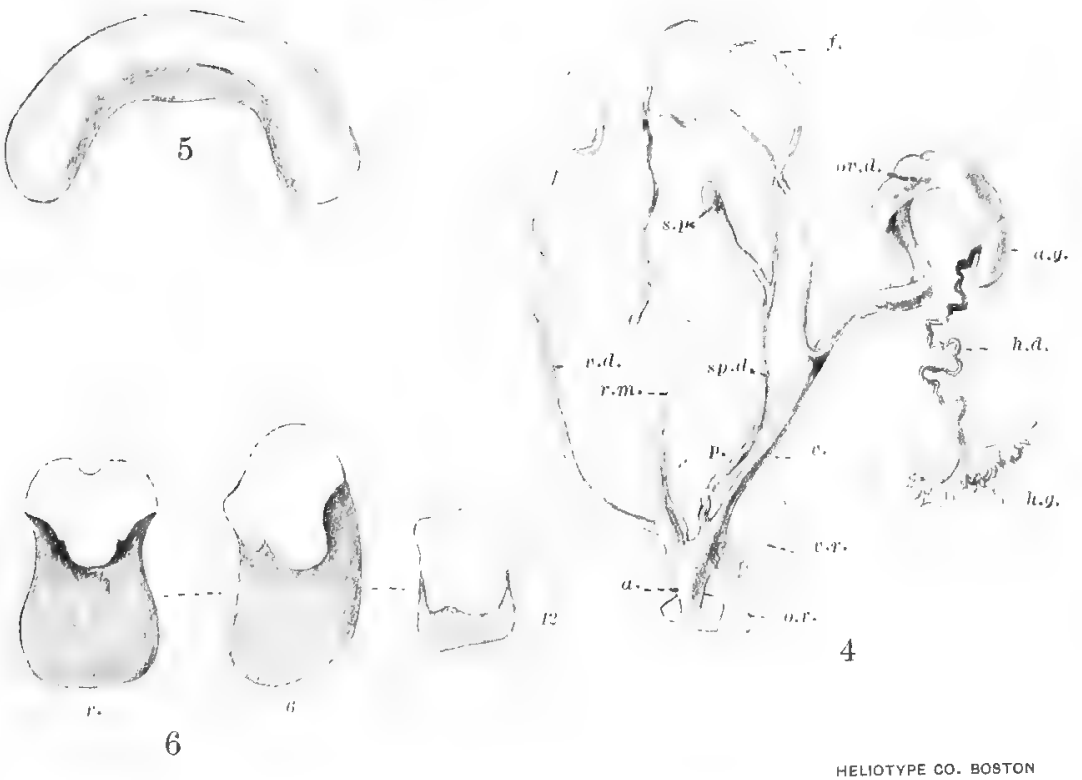

Cerion casablancae Bartsch 



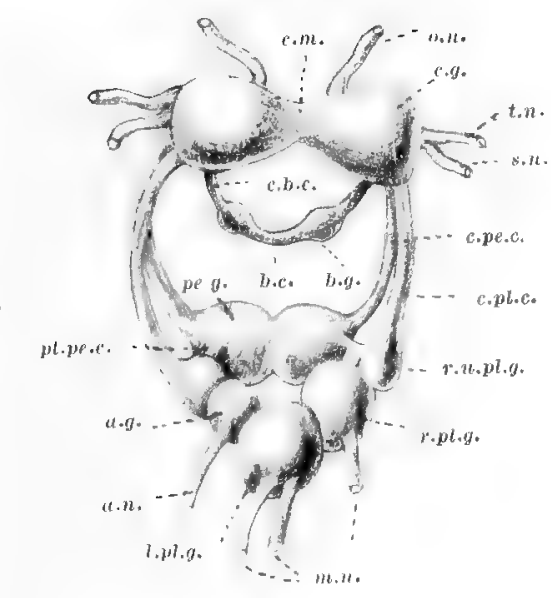

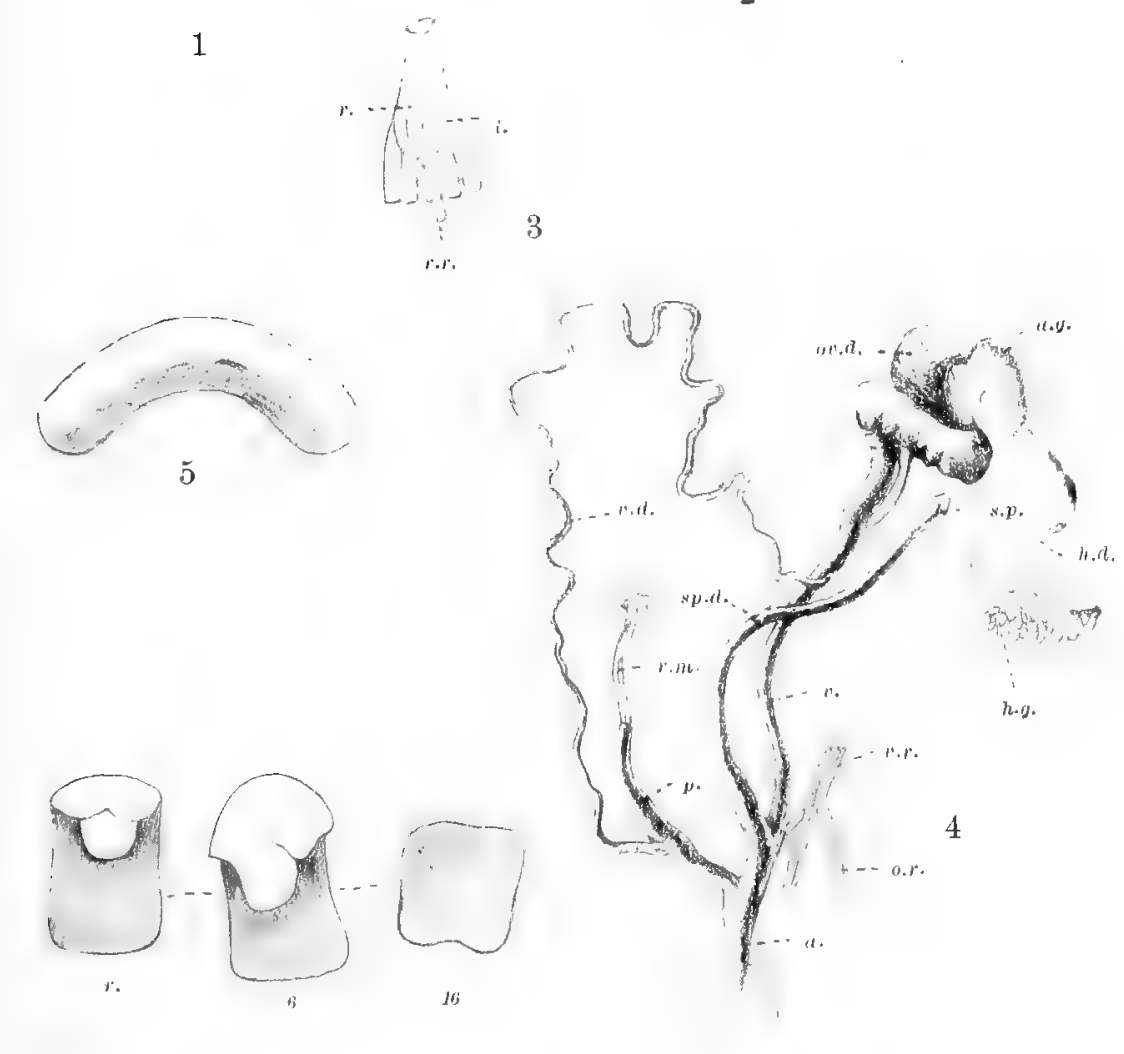

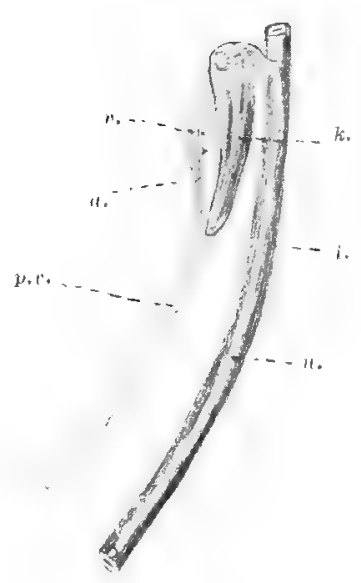

2

6

Cerion uva (Linnaeus). 


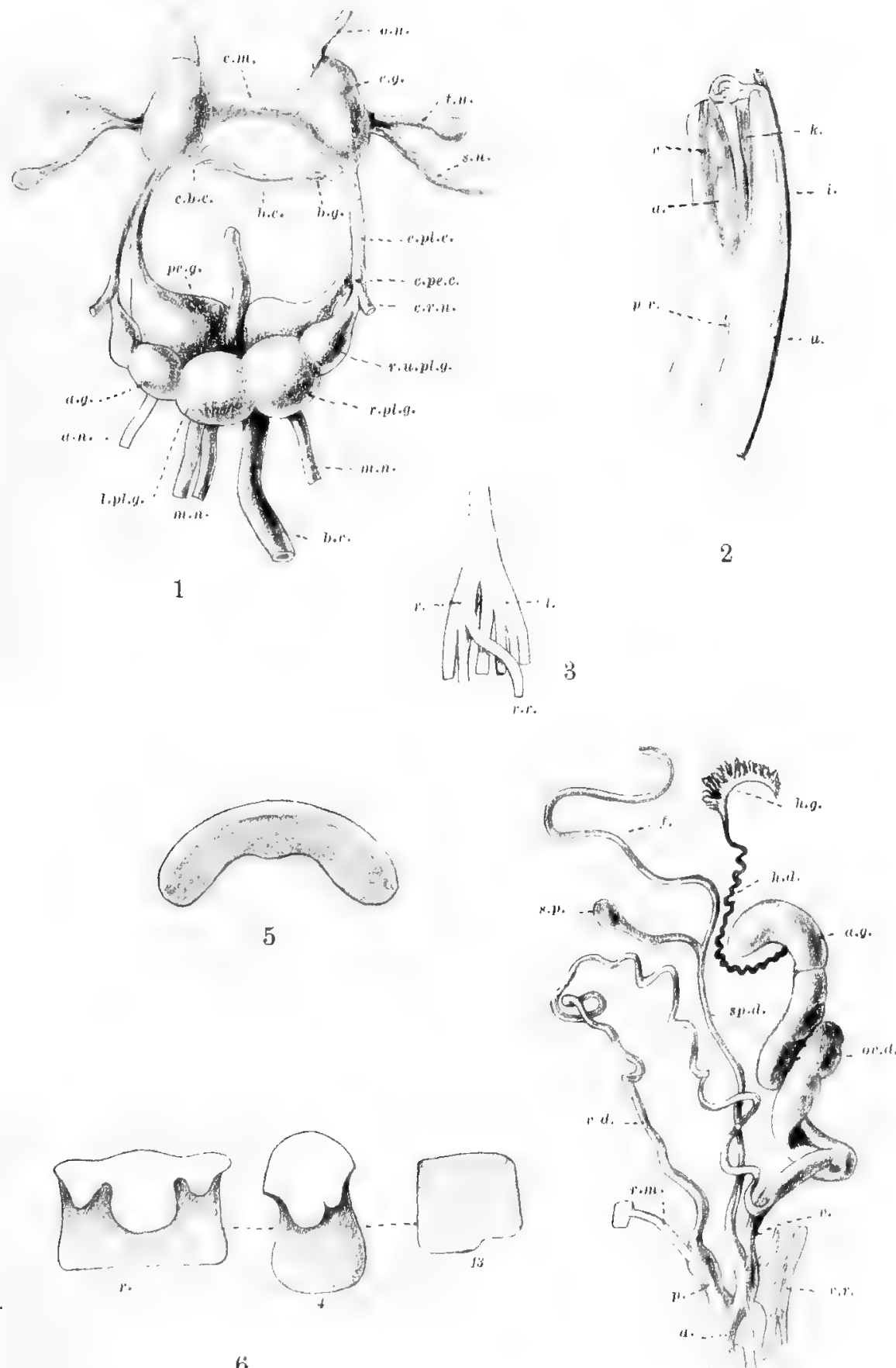

6 


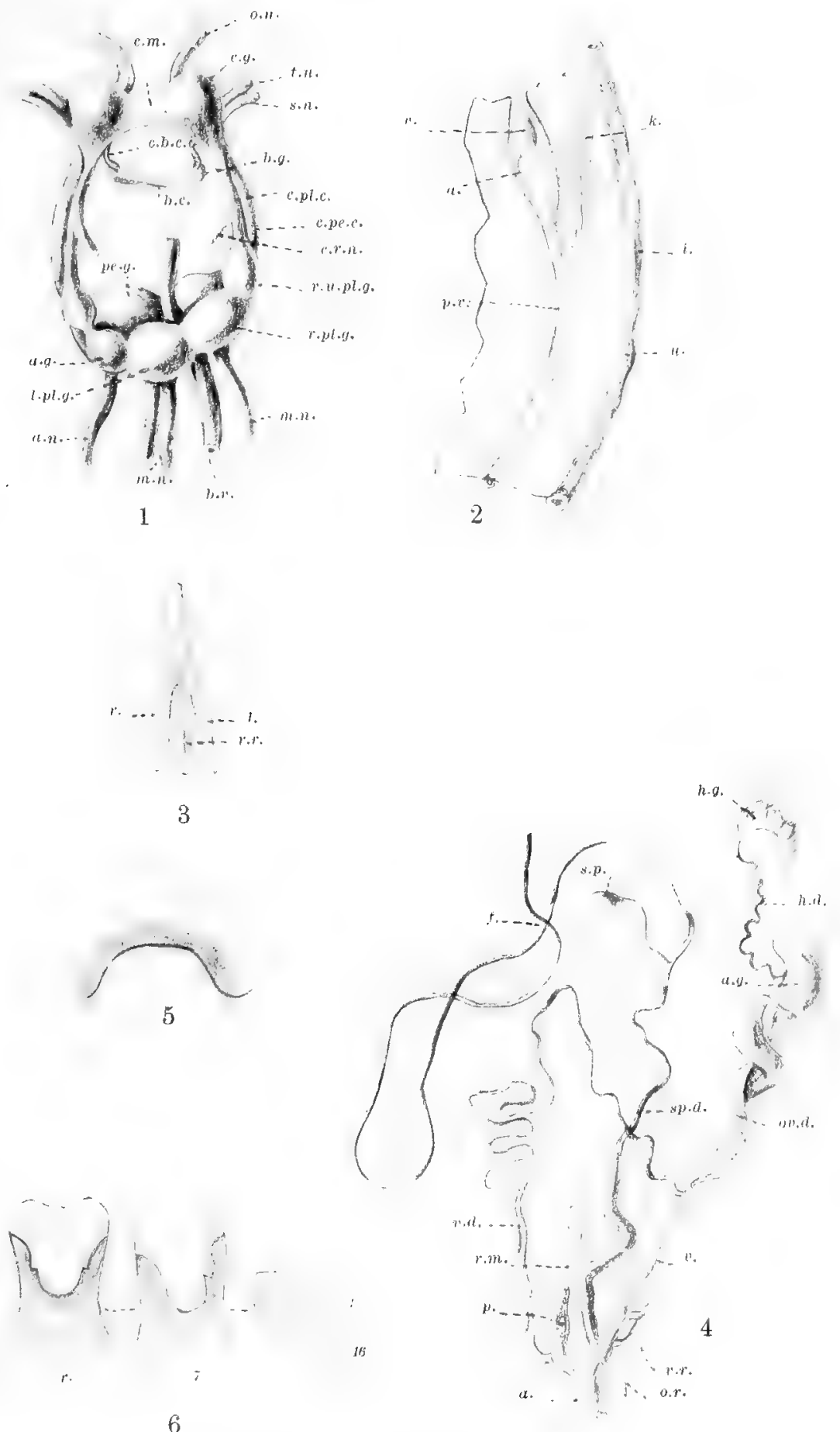

6

HELIOTYPE CO. BOSTON

Cerion viaregis Bartsch, 



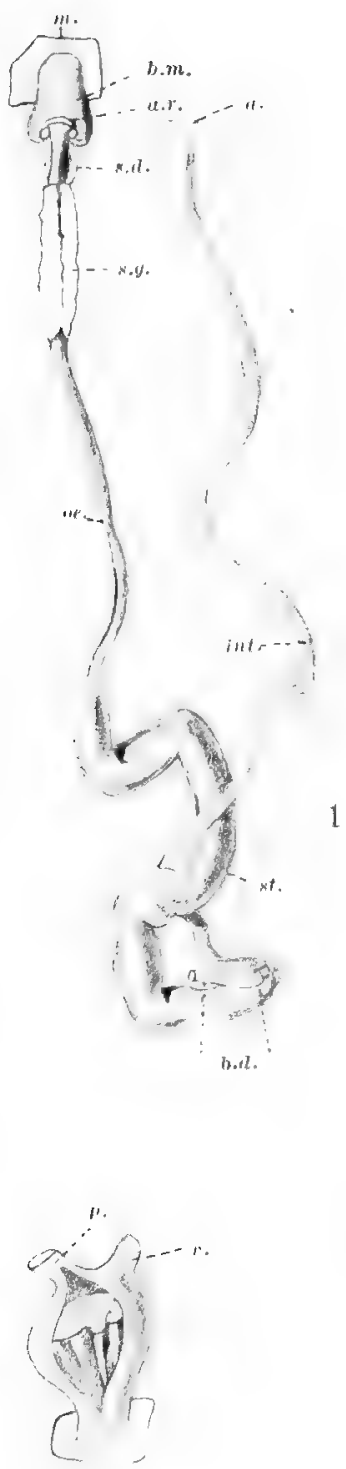

;
2
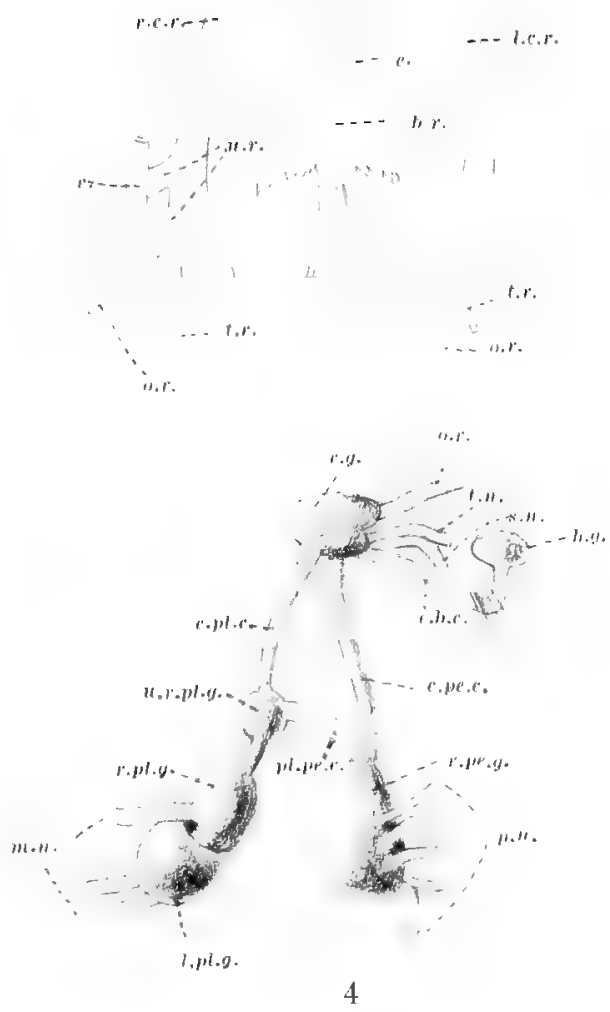

HELIOTYPE GO. BOSTON

Cerion incanum (Binney) and Cerion viaregis Bartsch. 



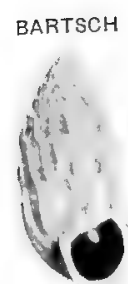

1

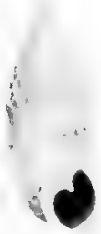

7

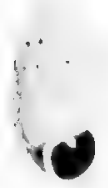

13
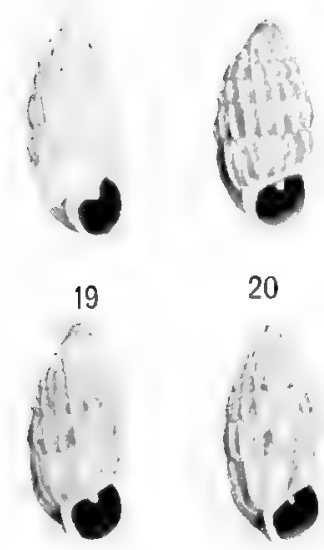

25

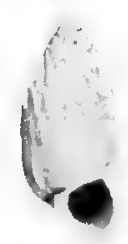

31

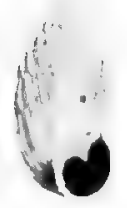

2

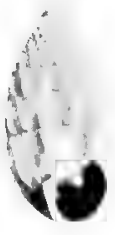

8

14

20

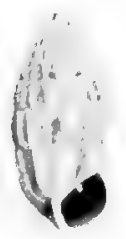

26

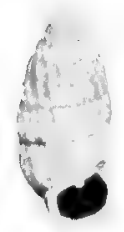

32

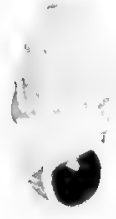

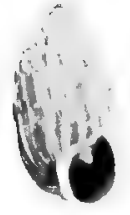

3

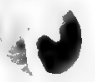

9

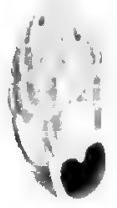

15

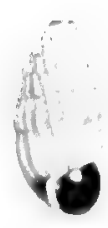

21

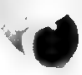

27

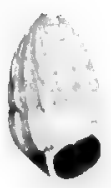

33
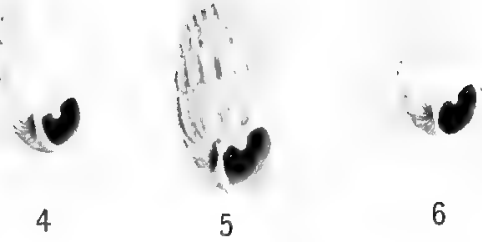

6

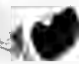

12
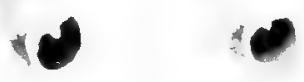

16

17

18
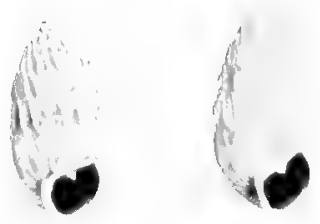

22

23

24
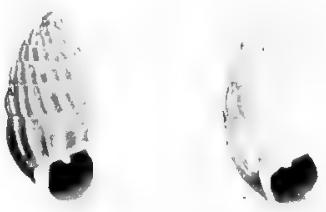

28

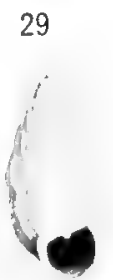

30

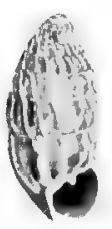

36

Flas. 1-36. Check series of Cerion viaregis. No. 21 type of Cerion viaregis. 

BARTSCH

PLATE 8
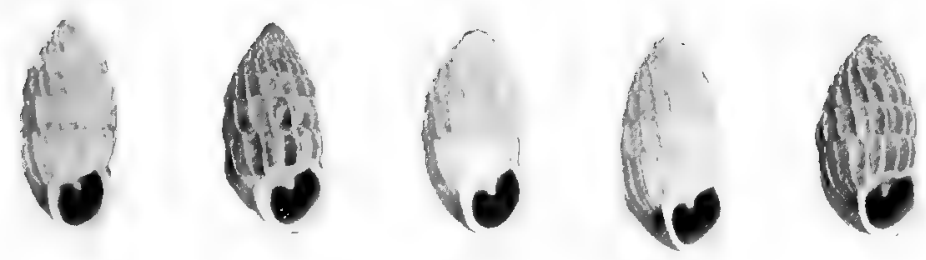

39

40

41

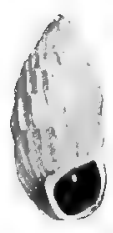

42
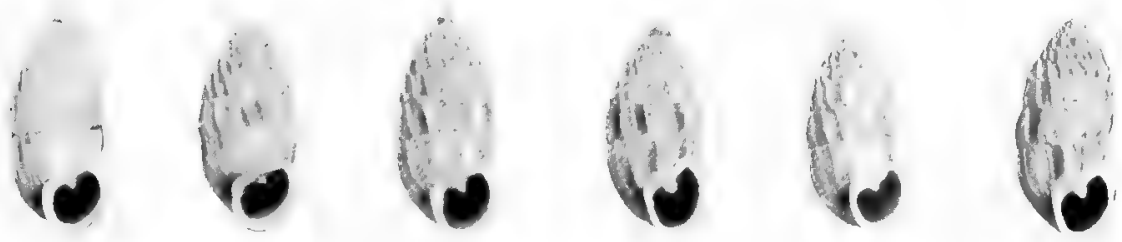

45

46

47

48
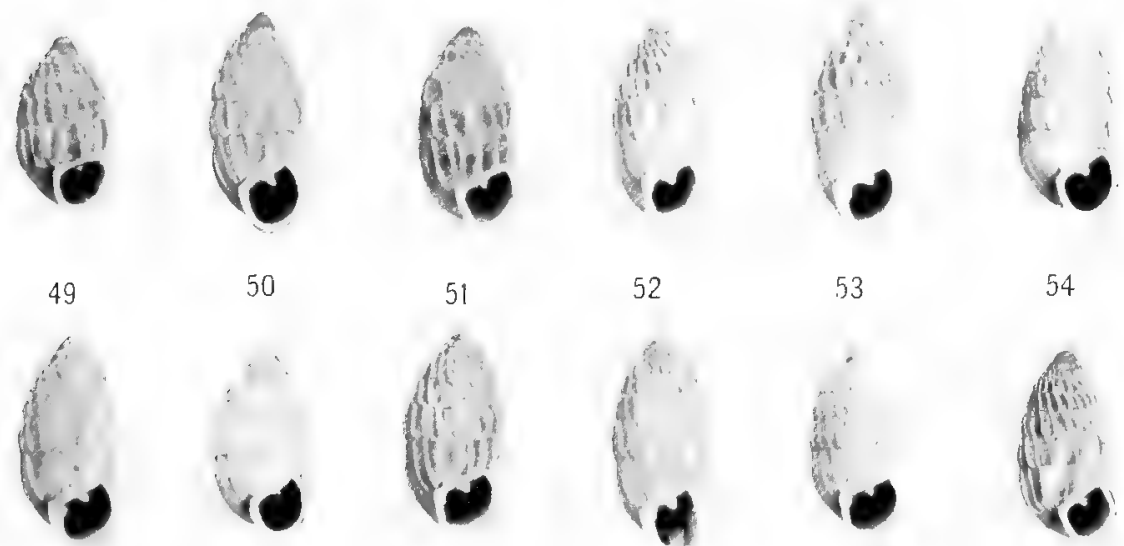

52

53

54

55

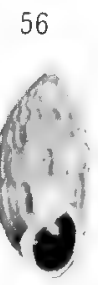

57

58

59

60
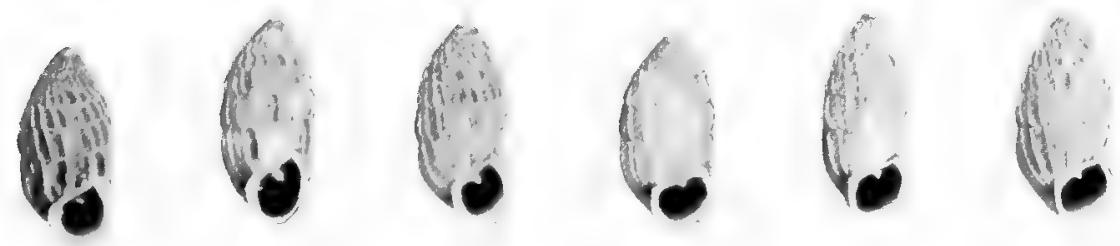

61

62
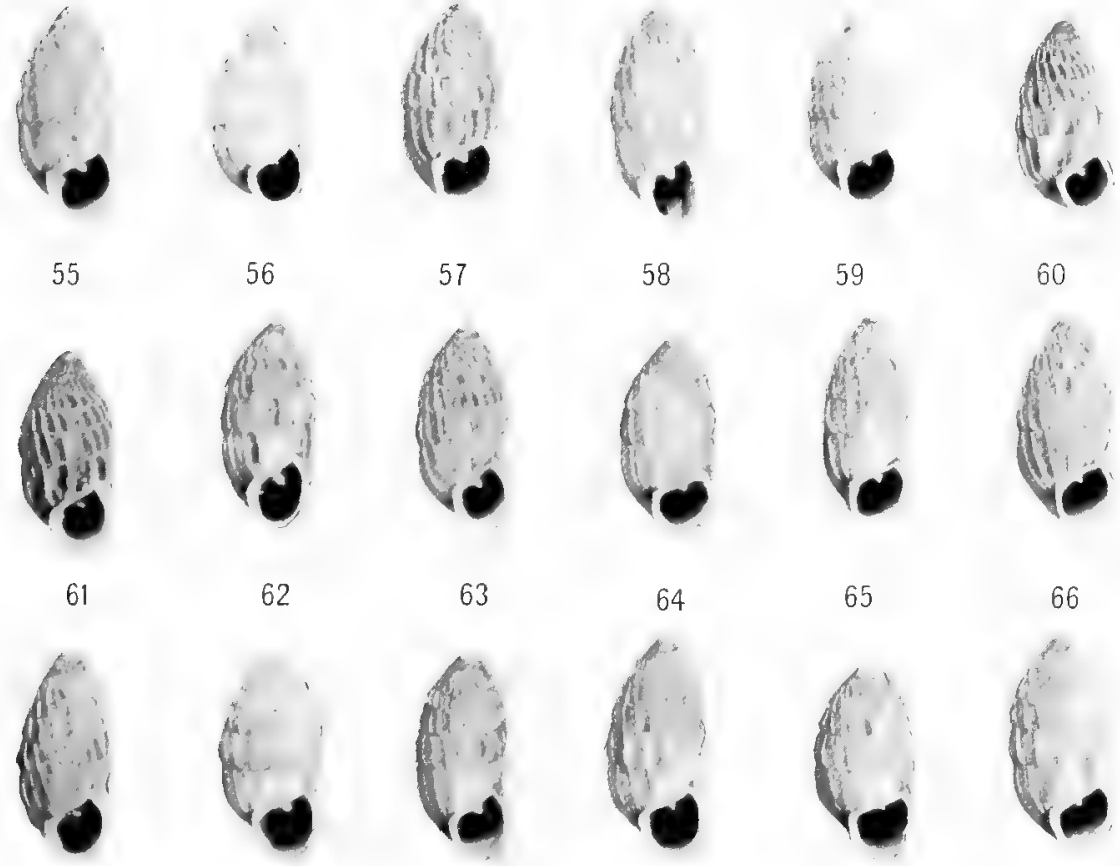

69

70

71

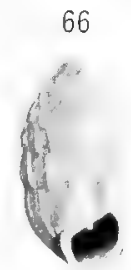

FIGs. 37-72. Check series of Cerion viaregis. 



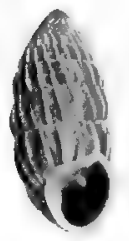

73

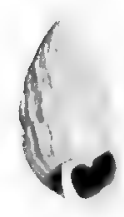

79

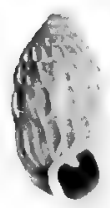

8.5

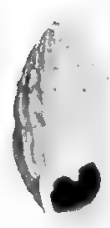

91

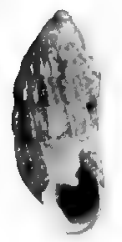

97

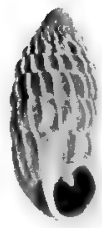

74

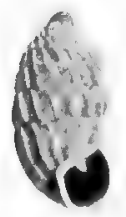

80

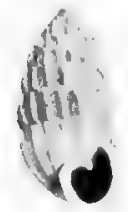

86

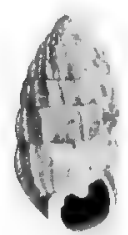

92

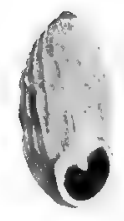

75

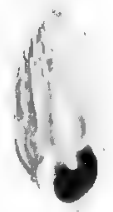

81

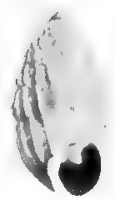

87

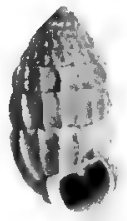

93

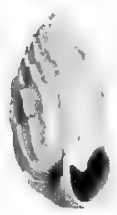

76

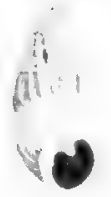

82

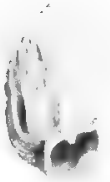

88

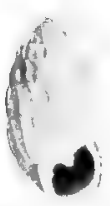

94
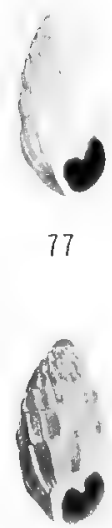

83

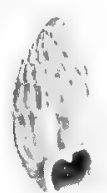

89

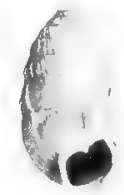

90

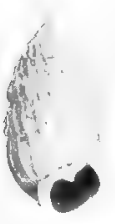

96

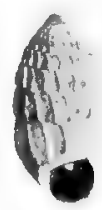

100

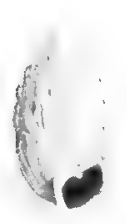

95

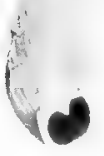

84

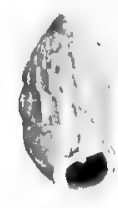

99

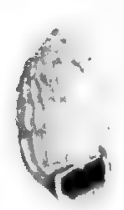

98

Figs. 73-100. Check series of Cerion viaregis. 


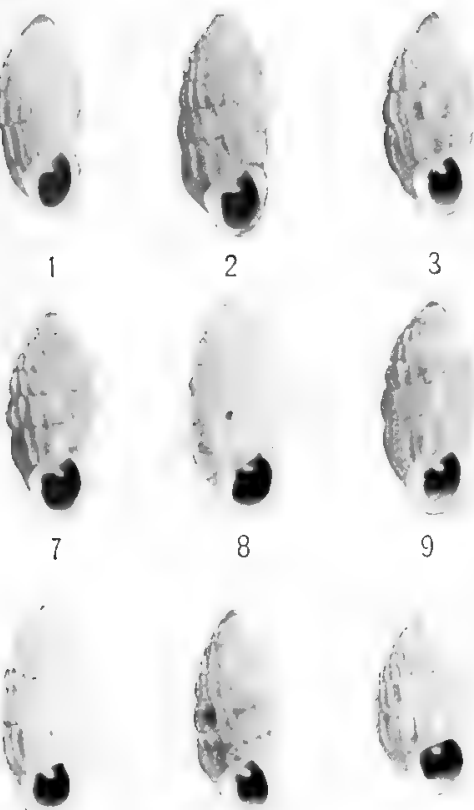

7

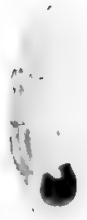

13

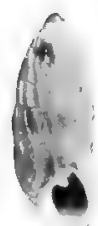

19

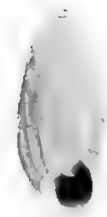

25

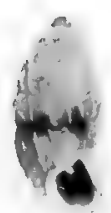

31
14

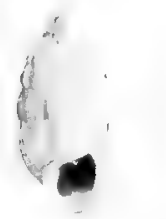

20

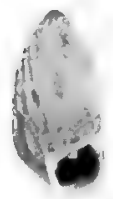

26

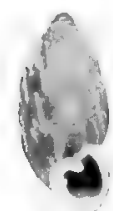

32
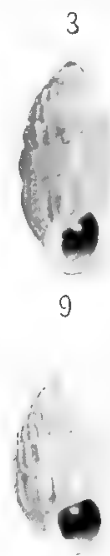

15
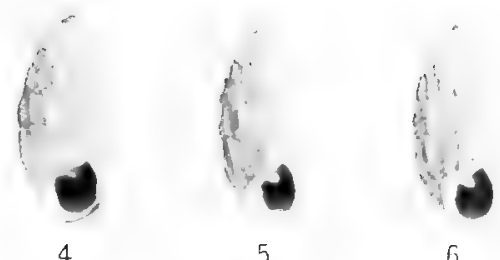

6

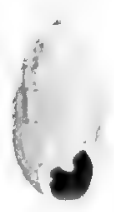

10
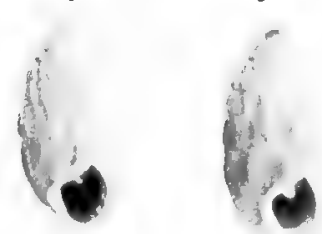

11

12
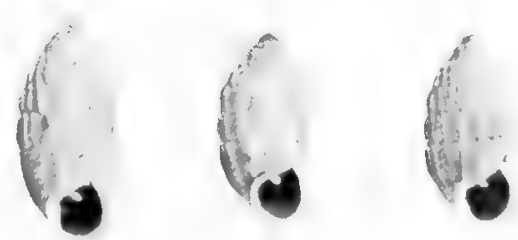

16

17

18
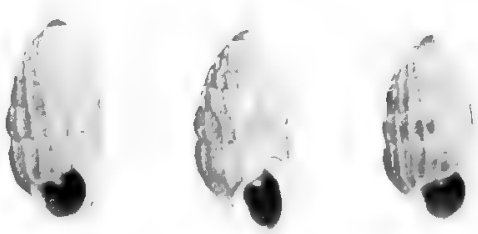

22

23

24
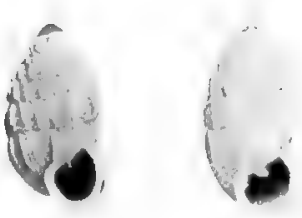

29

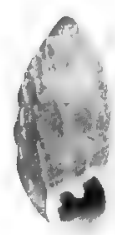

28

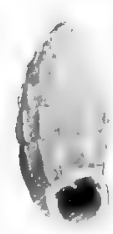

30

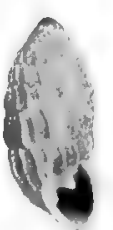

34

35

36

Figs, 1-36. First generation of Florida-grown Cerion viaregis from the Second Ragged Key north of Sands Key. 

BARTSCH
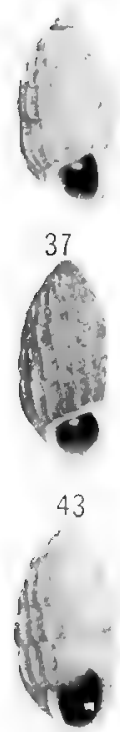

49

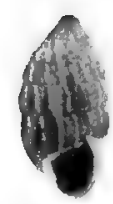

55

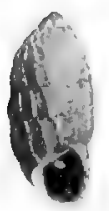

61

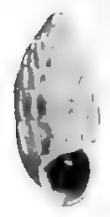

67

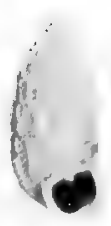

38

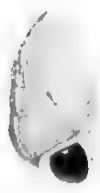

44

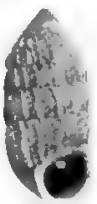

50

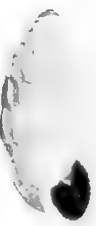

56

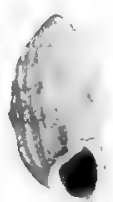

62

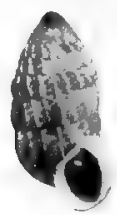

68

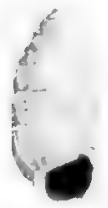

73
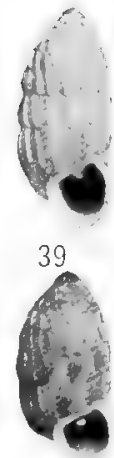

45
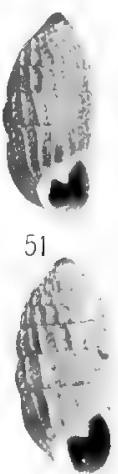

57

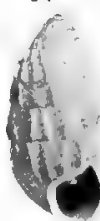

63

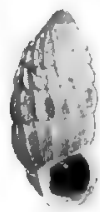

69

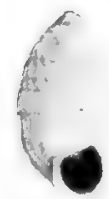

74
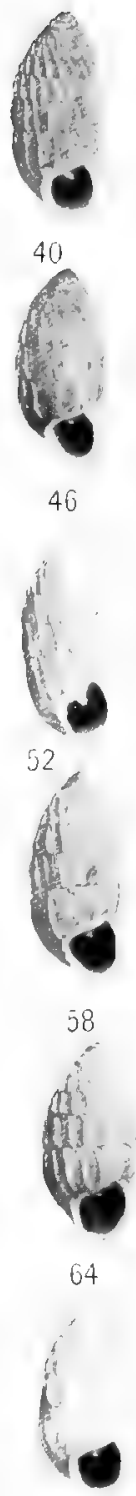

70

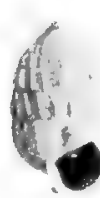

75
PLATE 11
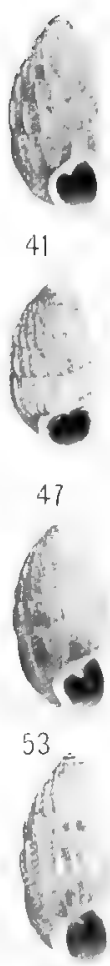

59
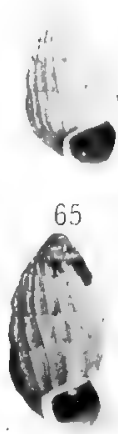

71

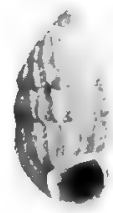

76

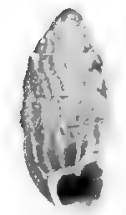

42

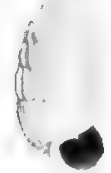

48

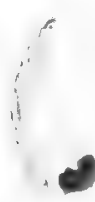

54

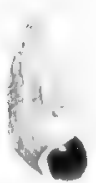

60
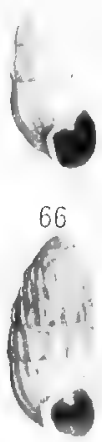

72

FIGs. 37-76. First generation of Florida-grown Cerion viaregis from the Second Ragged Key north of Sands Key. 



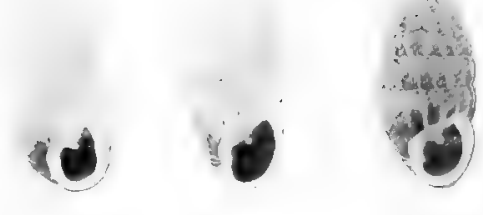

12

3

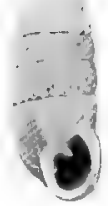

4

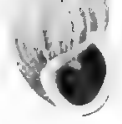

5

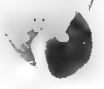

6
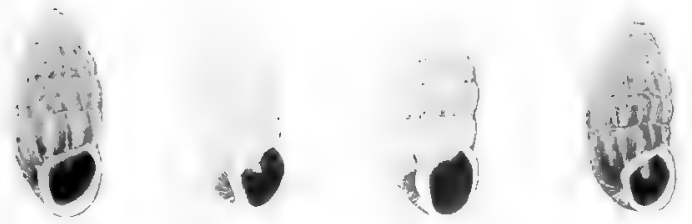

8

9

10

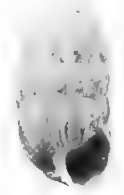

11

12
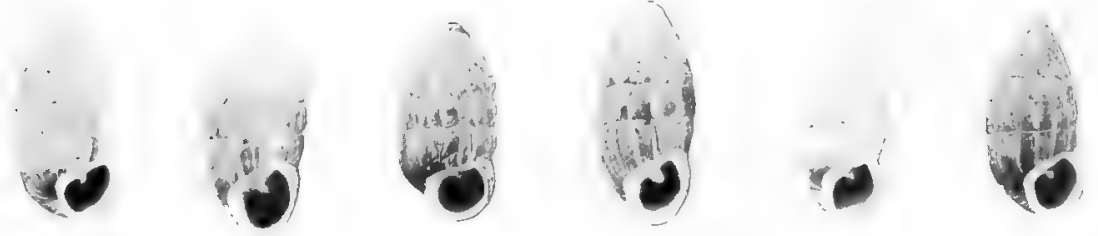

13

14

15

16

18

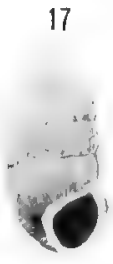

23

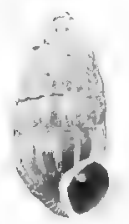

19

20

21

22

24
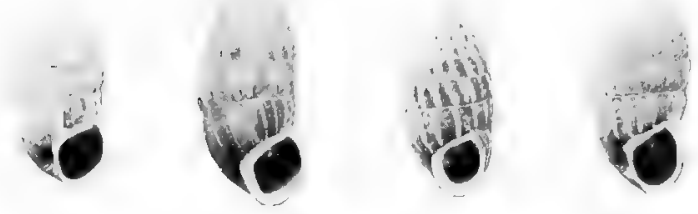

28
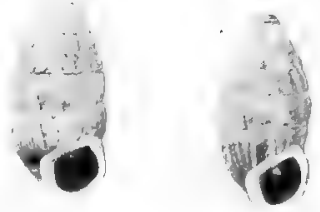

27

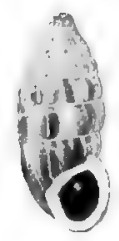

29

30
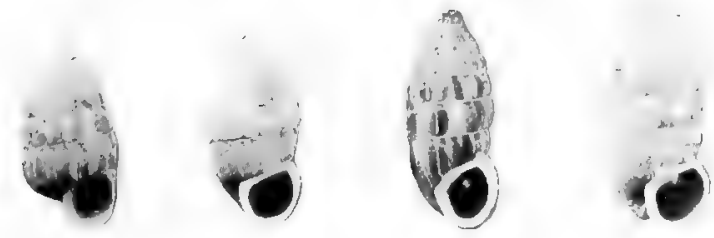

31

32

33

34

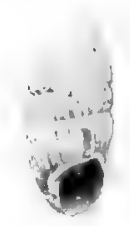

35

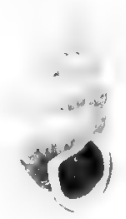

36

Figs. 1-36. First generation of Florida-grown Cerion viaregis from Boca Grande Key. 



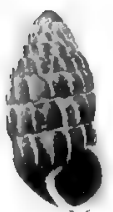

37

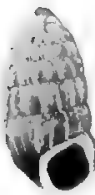

43

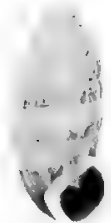

49

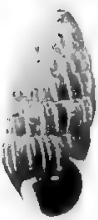

55

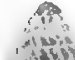
ing (1)

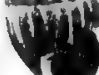

61

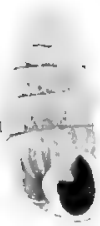

67

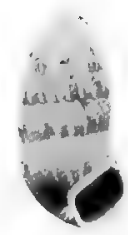

38

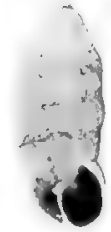

44

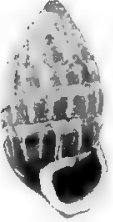

50

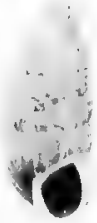

56

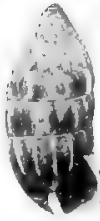

62

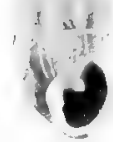

68

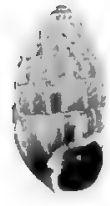

39

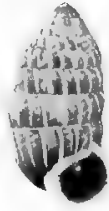

45

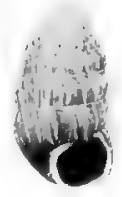

51

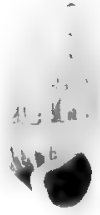

57

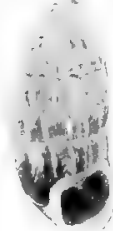

63

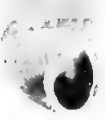

69

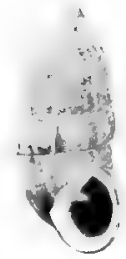

40

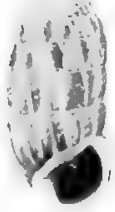

46

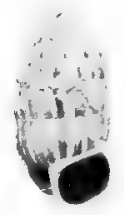

52

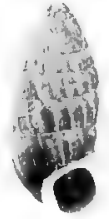

58

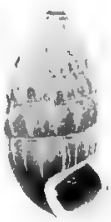

64

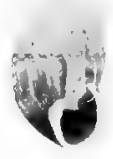

70
65

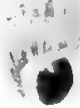

66

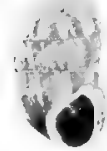

41

42

47

48

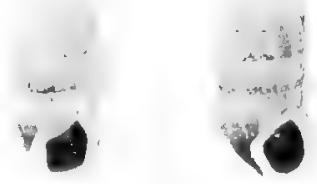

53

54
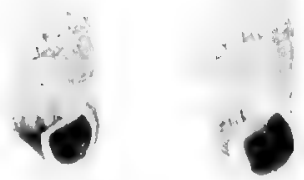

60

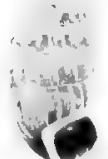

5
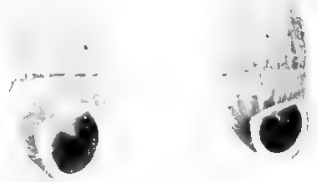

72

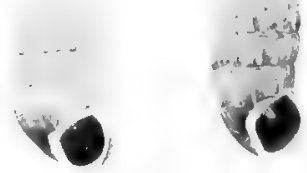

FIGs. 37-72. First generation of Florida-grown Cerion viaregis from Boca Grande Key. 



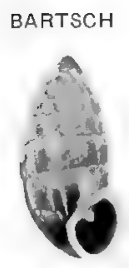

73

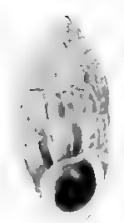

79

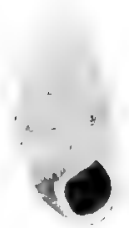

85

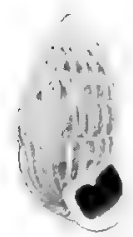

91

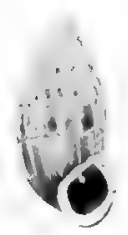

97

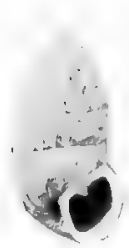

103

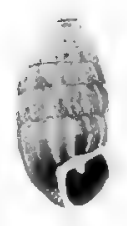

75

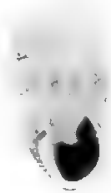

81

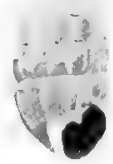

87

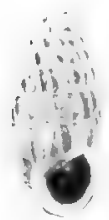

93

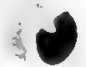

99

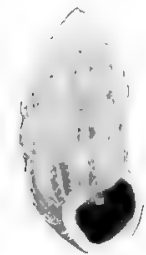

104

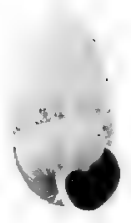

76

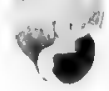

82

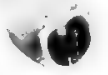

88

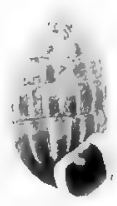

94

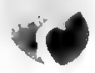

100

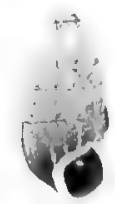

106

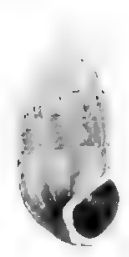

77

78
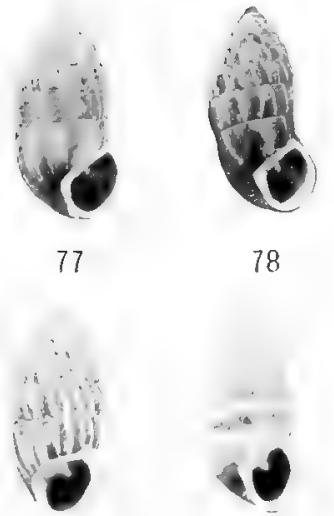

83

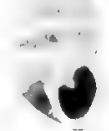

84

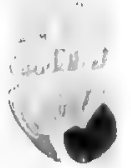

89

90
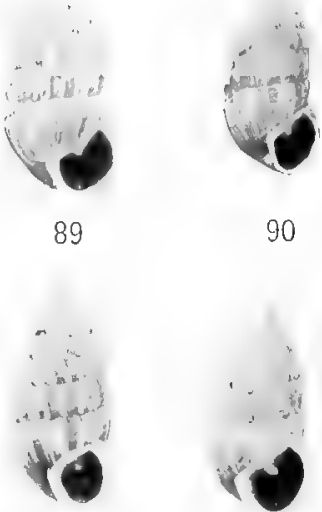

95

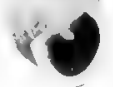

96

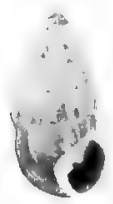

102

FIGS. 73-107. First generation of Florida-grown Cerion viaregis from Boca Grande Key. 



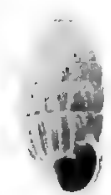

1

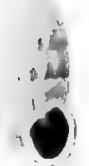

7

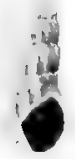

13

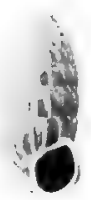

19

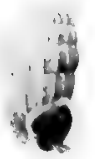

25

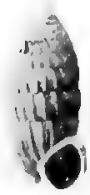

31

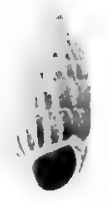

2

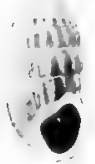

8

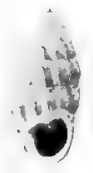

14

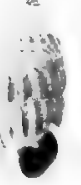

20

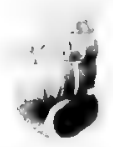

26

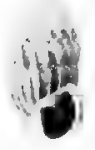

32

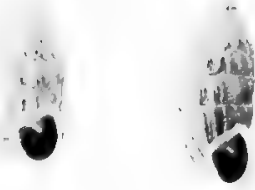

3

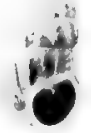

9

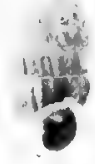

15

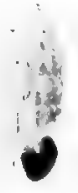

21

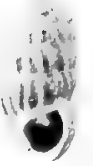

27

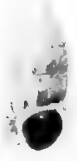

33

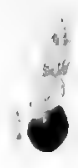

10

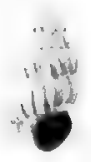

16

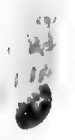

22

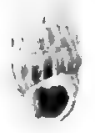

28

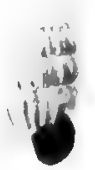

34

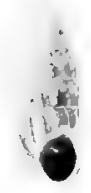

5

6

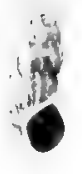

11

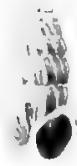

12

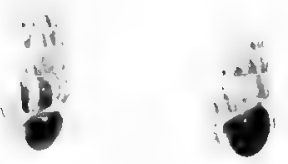

18
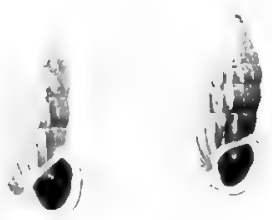

23

24

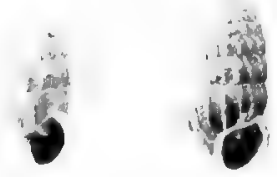

29

30

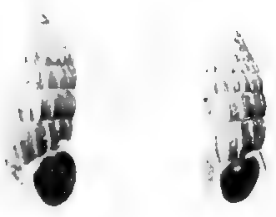

$35 \quad 30$

FIGs. 1-36. First generation of Florida-grown Cerion viaregis from Colony $\mathrm{E}$ on Loggerhead Key. 



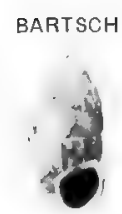

37

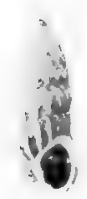

43

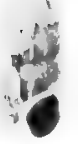

49

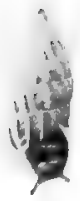

55

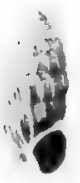

61

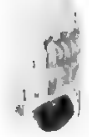

67

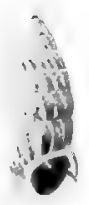

38

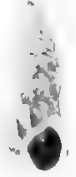

44

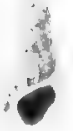

50

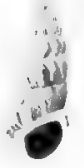

56

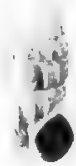

62

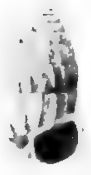

39

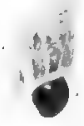

45

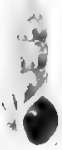

51

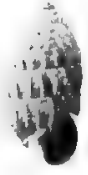

57

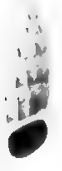

63

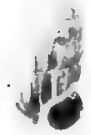

69

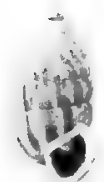

40

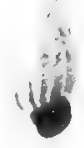

46

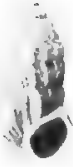

52

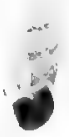

58

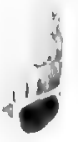

64
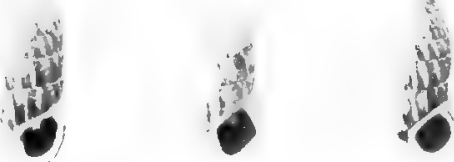

70

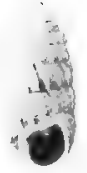

41

42

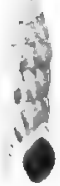

48

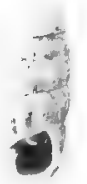

53

54

60

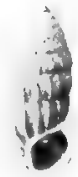

65

66

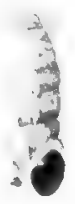

FiGs. 37-72. First generation of Florida-grown Cerion viaregis from Colony E on Loggerhead Key. 



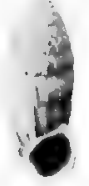

73

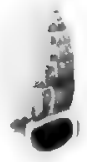

74

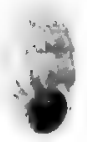

80

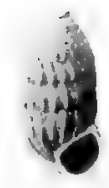

75

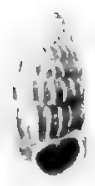

76
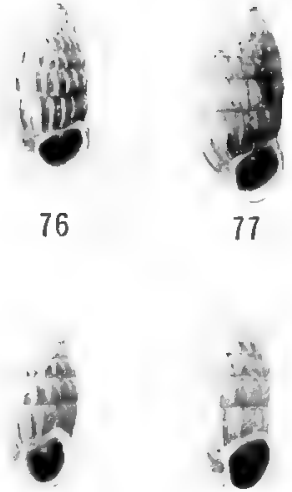

82

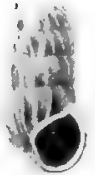

88

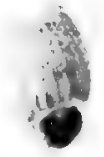

94

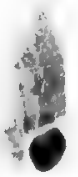

100

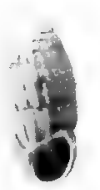

106

95

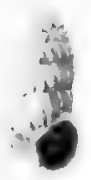

101

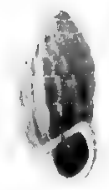

105

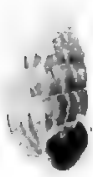

104

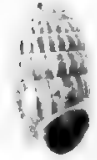

99
77

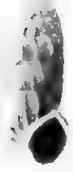

78

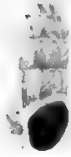

83

84
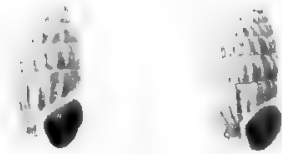

90

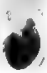

89

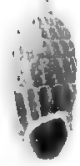

96

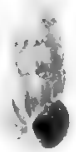

102

FIGs. 73-108. First generation of Florida-grown Cerion viaregis from Colony E on Loggerhead Kicy. 



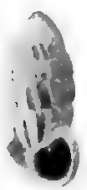

109

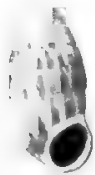

115

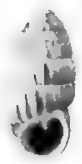

121

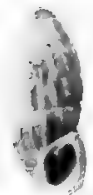

127

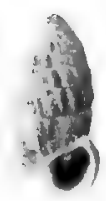

133

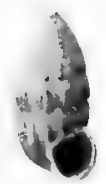

139

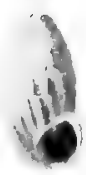

110

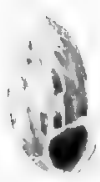

116

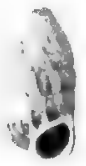

122

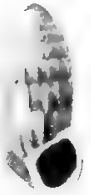

128

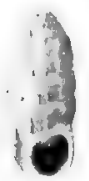

134

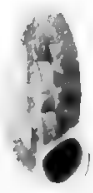

140

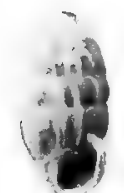

111

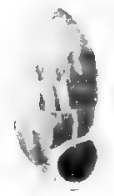

117

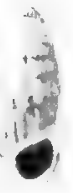

123

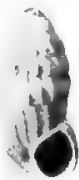

129

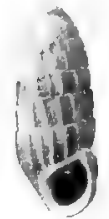

135

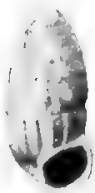

141

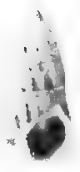

112

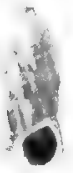

118

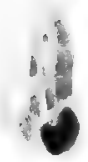

113

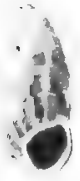

114

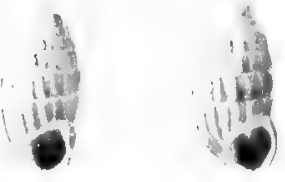

119

120
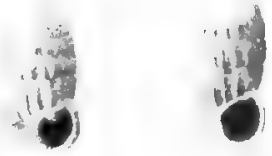

124

125

126
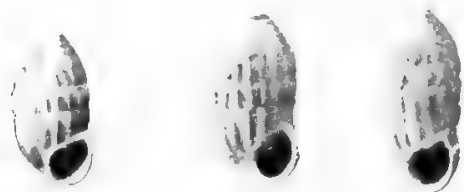

130

131

132
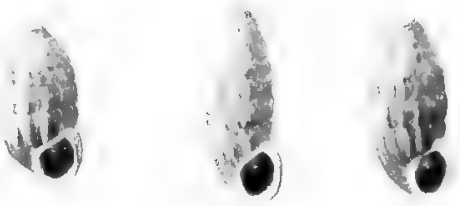

137

138

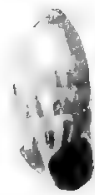

143

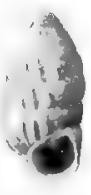

144

Fras, 109-144. First generation of Florida-grown Cerion viaregis from Colony $\mathbf{E}$ on I.otgerhead Key. 



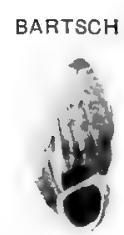

145

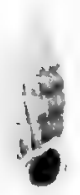

151

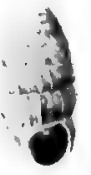

146

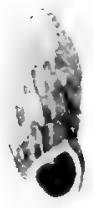

147

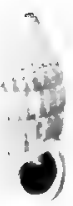

148
PLATE 19

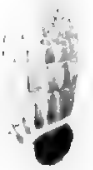

149

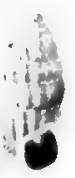

152

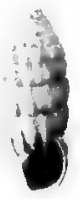

153

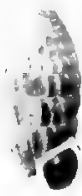

154

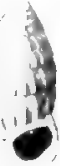

155

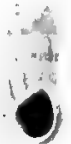

161

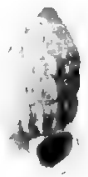

156

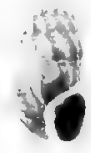

162

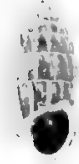

157

158

159

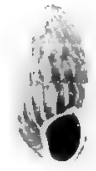

160
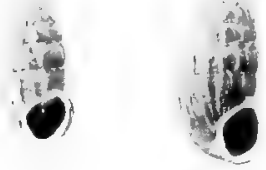

167

163

164

165

166
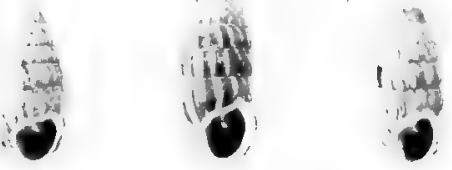

169

170

171

172

173

174
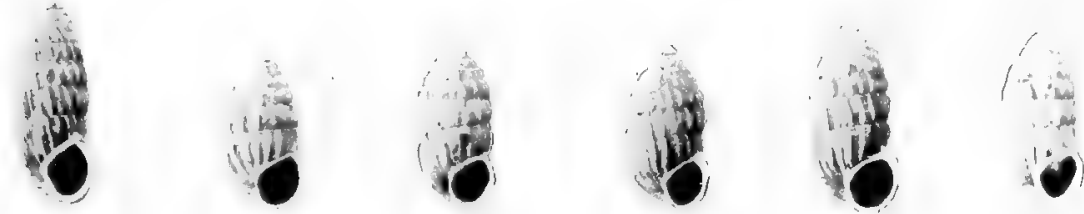

175

177

178

179

180

FIGS. 145-180. First generation of Florida-grown Cerion viaregis from Colony E on Loggerhead Key. 



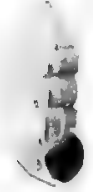

181

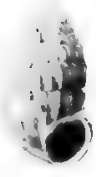

182

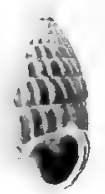

183

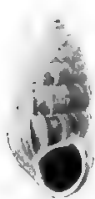

184

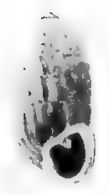

185

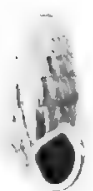

186

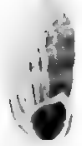

187

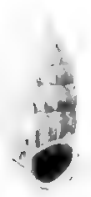

188

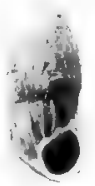

189

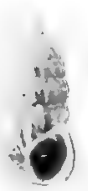

190

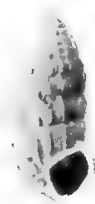

191

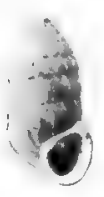

192

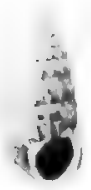

193

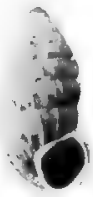

194

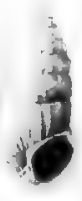

195

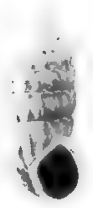

196

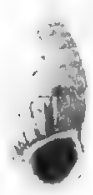

197

198
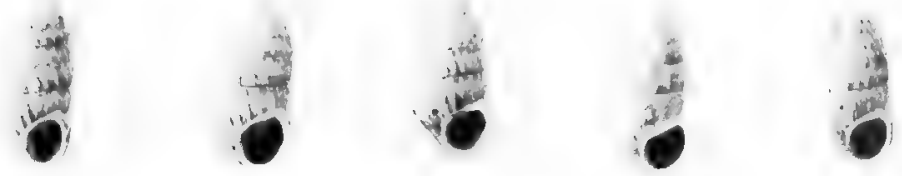

202

203

204
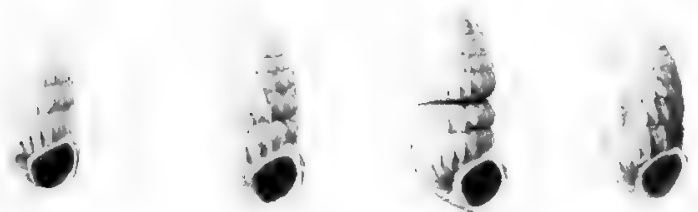

208

209
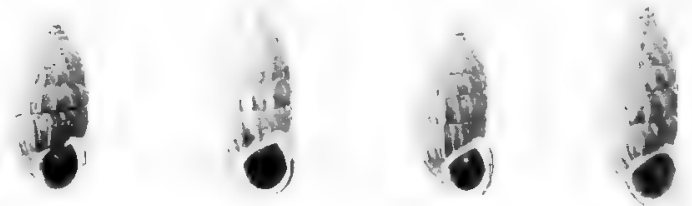

215

210

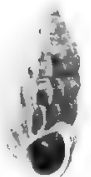

Figs. 181-216. First'generation of Florida-grown Cerion viaregis from Colony $\mathrm{E}$ on Loggerhead Key. 



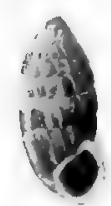

217

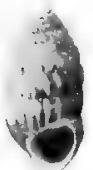

223

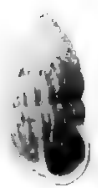

229

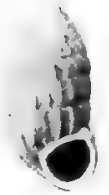

218

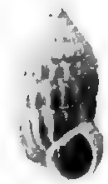

224

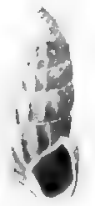

230

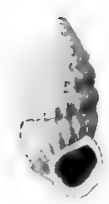

219

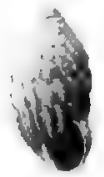

225

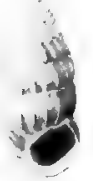

231

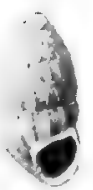

220

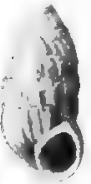

226

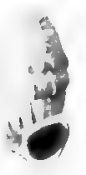

232

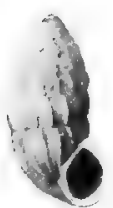

221

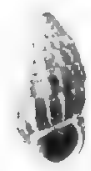

227

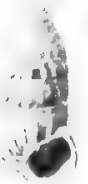

233

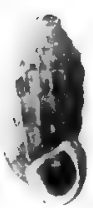

222

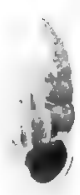

228

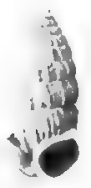

234

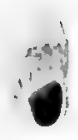

235

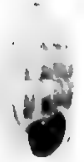

241

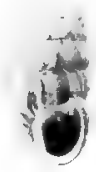

236

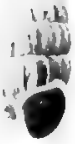

242

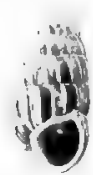

237

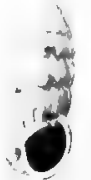

243

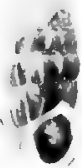

248

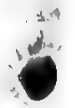

238

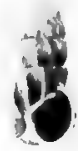

244

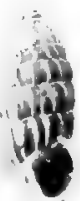

249

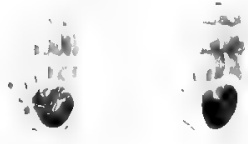

$239 \quad 240$

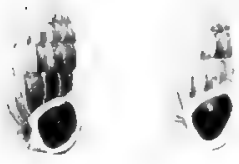

$245 \quad 246$

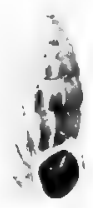

250

FIGS. 217-250. First generation of Florida-grown Cerion viaregis from Colony $\mathrm{E}$ on Loggerhead Key. 



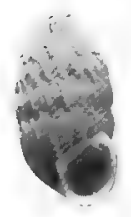

1

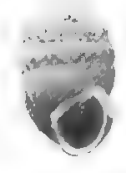

2

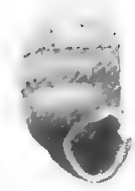

3

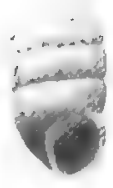

4

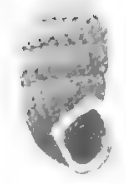

5

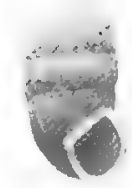

6

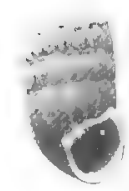

7

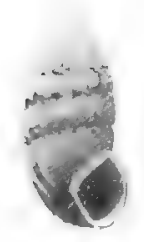

8

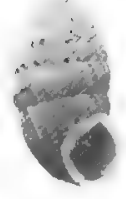

9

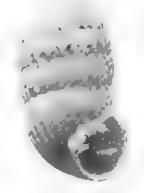

10

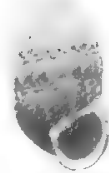

17

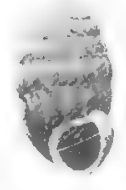

11

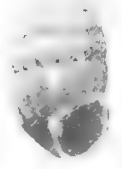

18

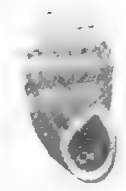

12

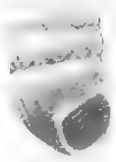

19

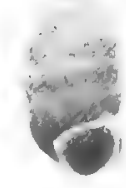

13

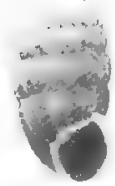

14

15

16

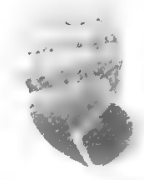

20

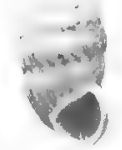

21

22

23

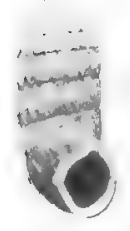

29

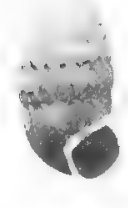

30

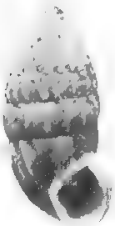

37

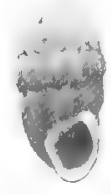

24

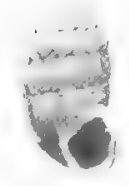

25

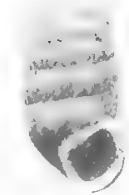

26

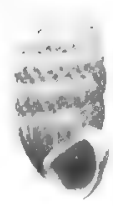

31

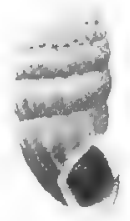

32

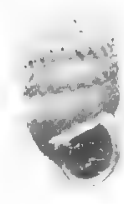

33

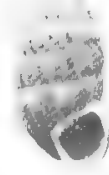

27

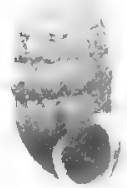

34

35

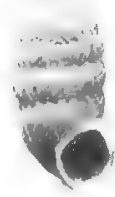

38

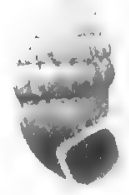

39

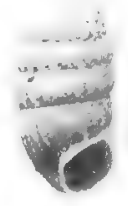

40

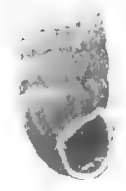

28

36

FIGs. 1-42. First generation of Florida-grown Cerion viaregis from Colony $\mathrm{F}$ on Loggerhead Key. 



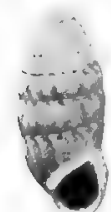

43

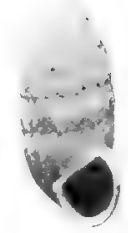

44

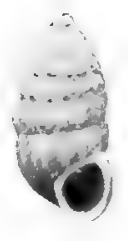

45

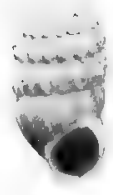

46

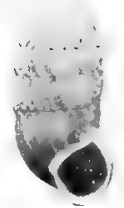

47

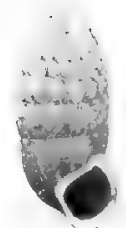

48

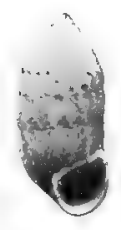

49

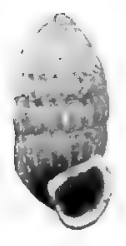

50

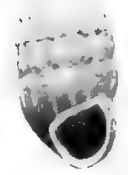

51

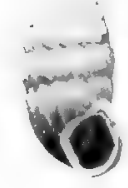

52

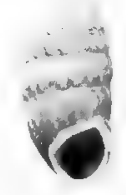

53

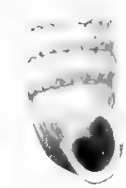

54

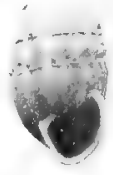

55

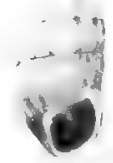

56

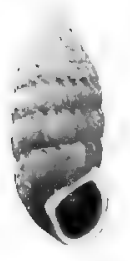

57

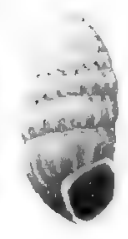

58

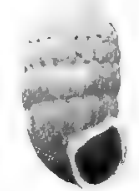

59

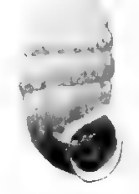

60

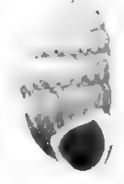

61

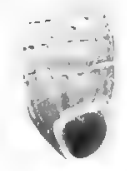

62

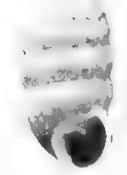

63

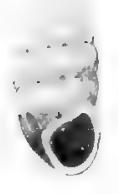

64

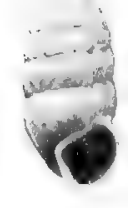

65

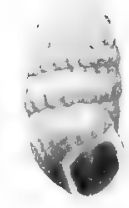

66

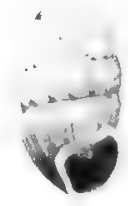

67

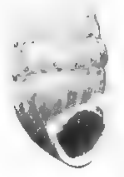

68

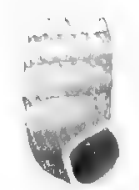

69

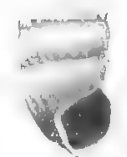

70
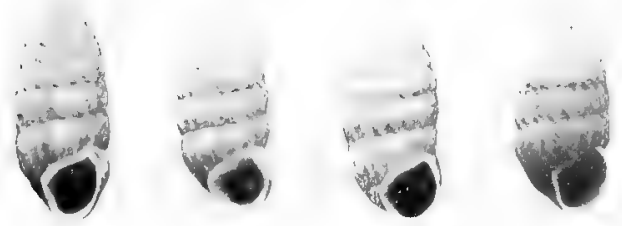

74

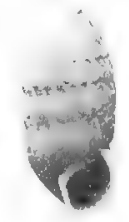

75
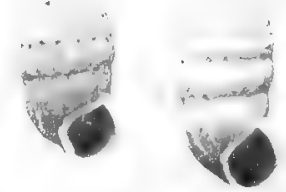

77
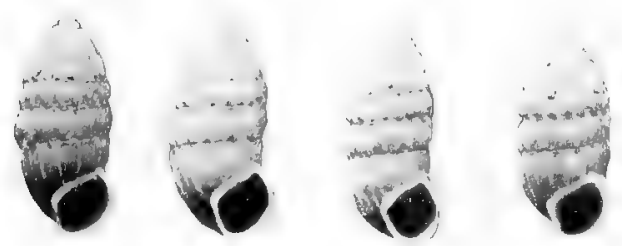

81

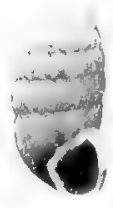

82

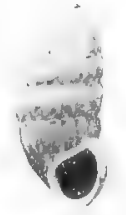

83

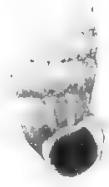

84

FIas. 43-84. First generation of Florida-grown Cerion viaregis from Colony $\mathrm{F}$ on I soggerhead Key. 



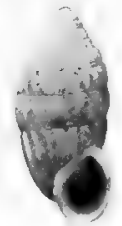

85

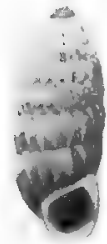

92

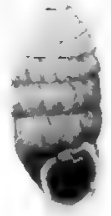

86

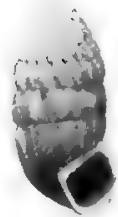

87

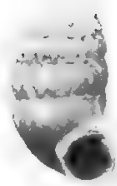

88

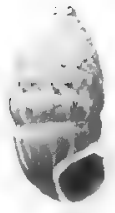

89

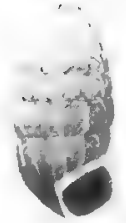

90

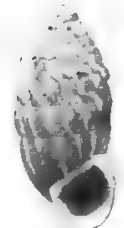

91

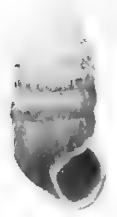

98

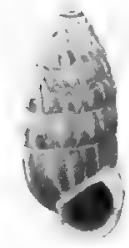

93

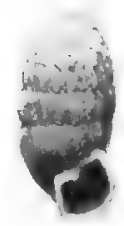

94

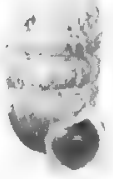

100

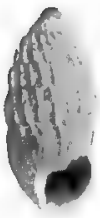

3

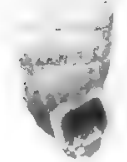

99

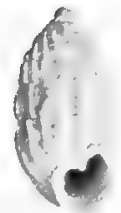

4

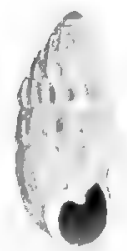

5

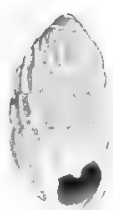

6

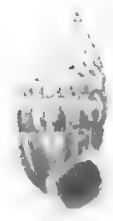

96
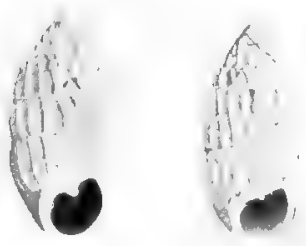

2

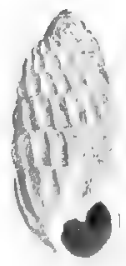

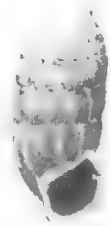

97
8

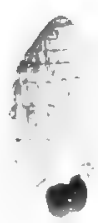

77

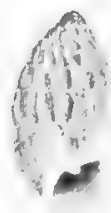

7

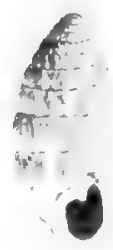

78

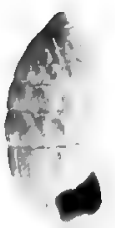

73

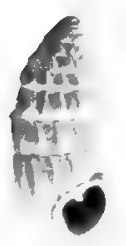

74

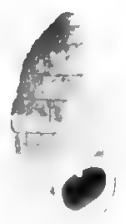

75

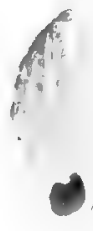

76

Figs. 85-100 at the top of plate. First generation of Florida-grown Cerion viaregis from Colony $\mathrm{F}$ in Loggerhead Key.

FIas. 1-8 of the middle series. Second generation of Florida-grown Cerion viaregis from the Second Ragged Key north of Sands Key.

FIGs. 73-78 of the bottom series. First generation of Florida-grown Cerion viaregis from Colony G on Loggerhead Key. 


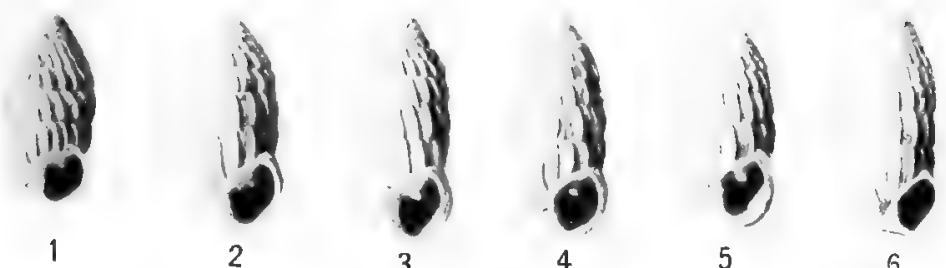

PLATE 25
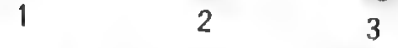

5

6
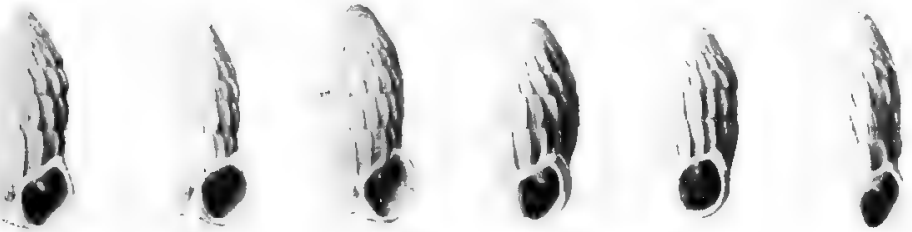

7

8

9

10

11

12

13
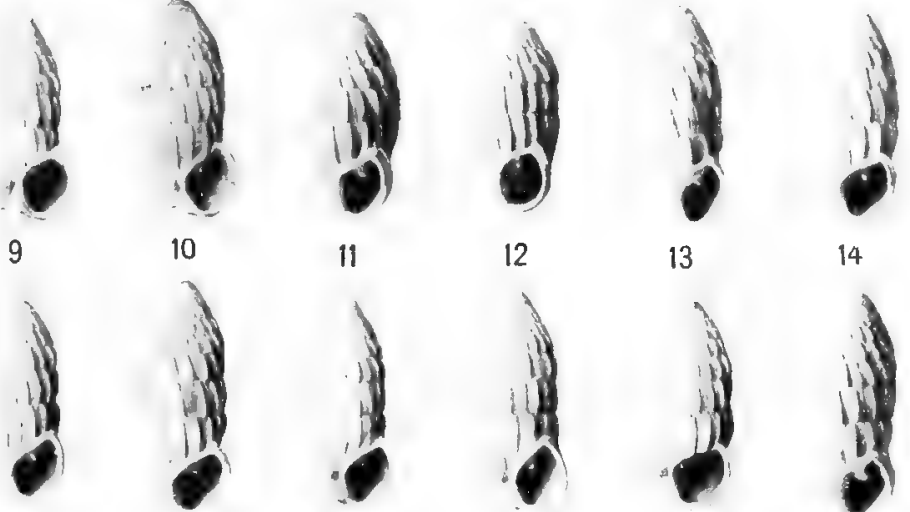

16

17

18
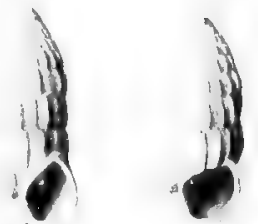

14

15
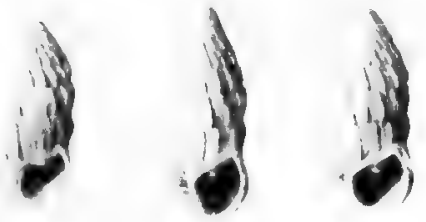

19

20

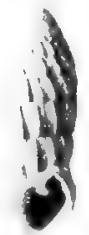

21

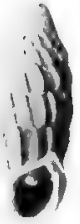

23

24
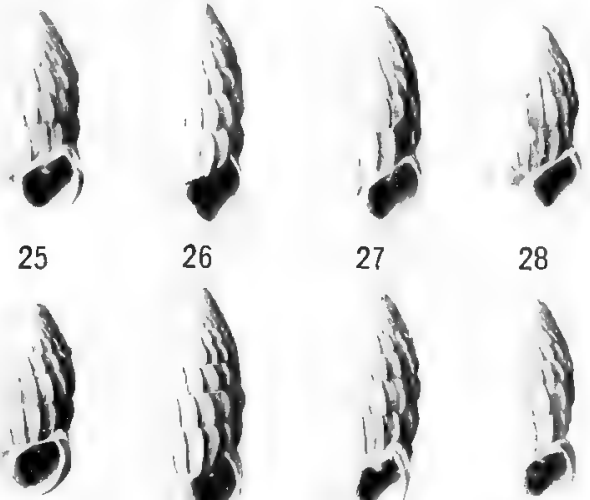

22
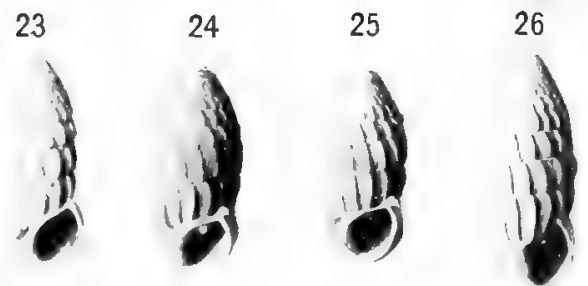

27

28
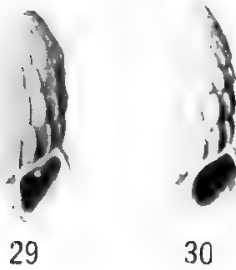

31
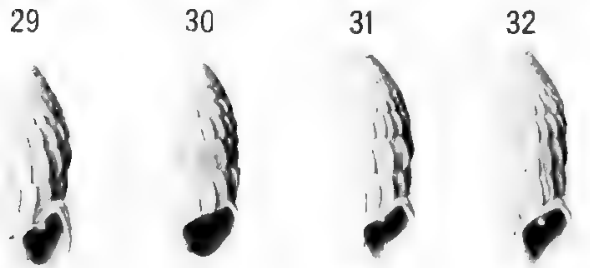

33
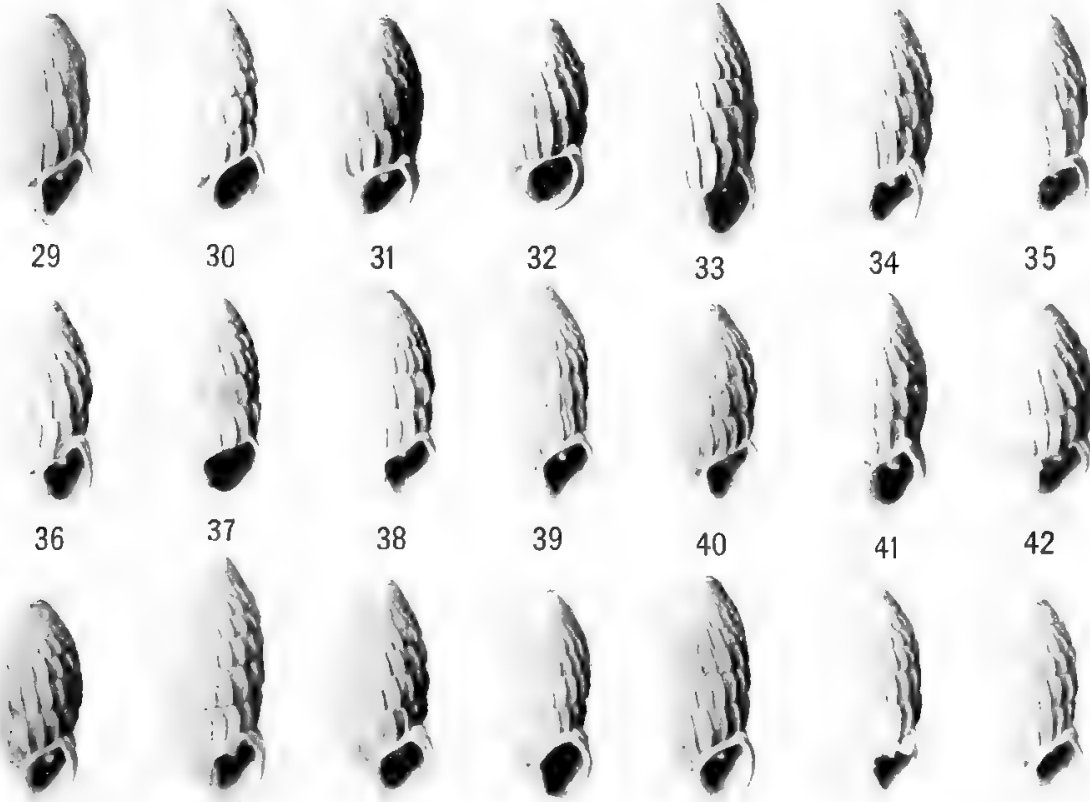

38

39
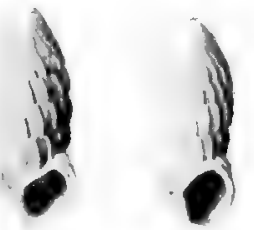

40

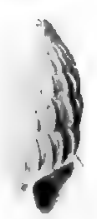

34

35
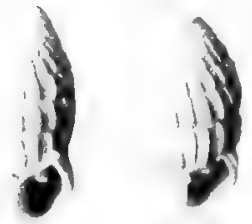

43

44

45

46

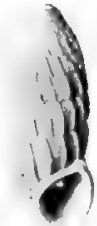

41

42
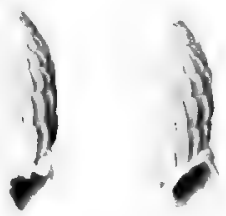

47

48

49

Figs. 1-49. First generation of Florida-grown Cerion viaregis from Colony $\mathrm{G}$ on Loggerhead Key. 1915. 

BARTSCH
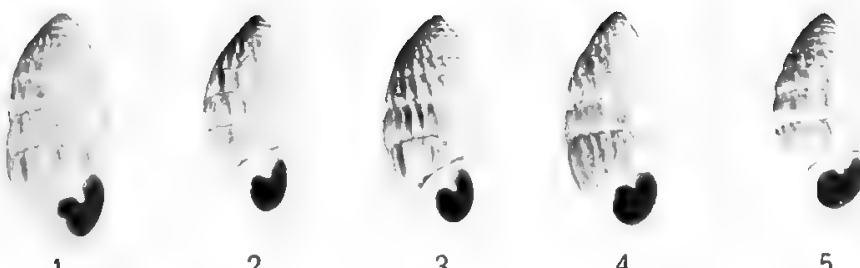

PLATE 26
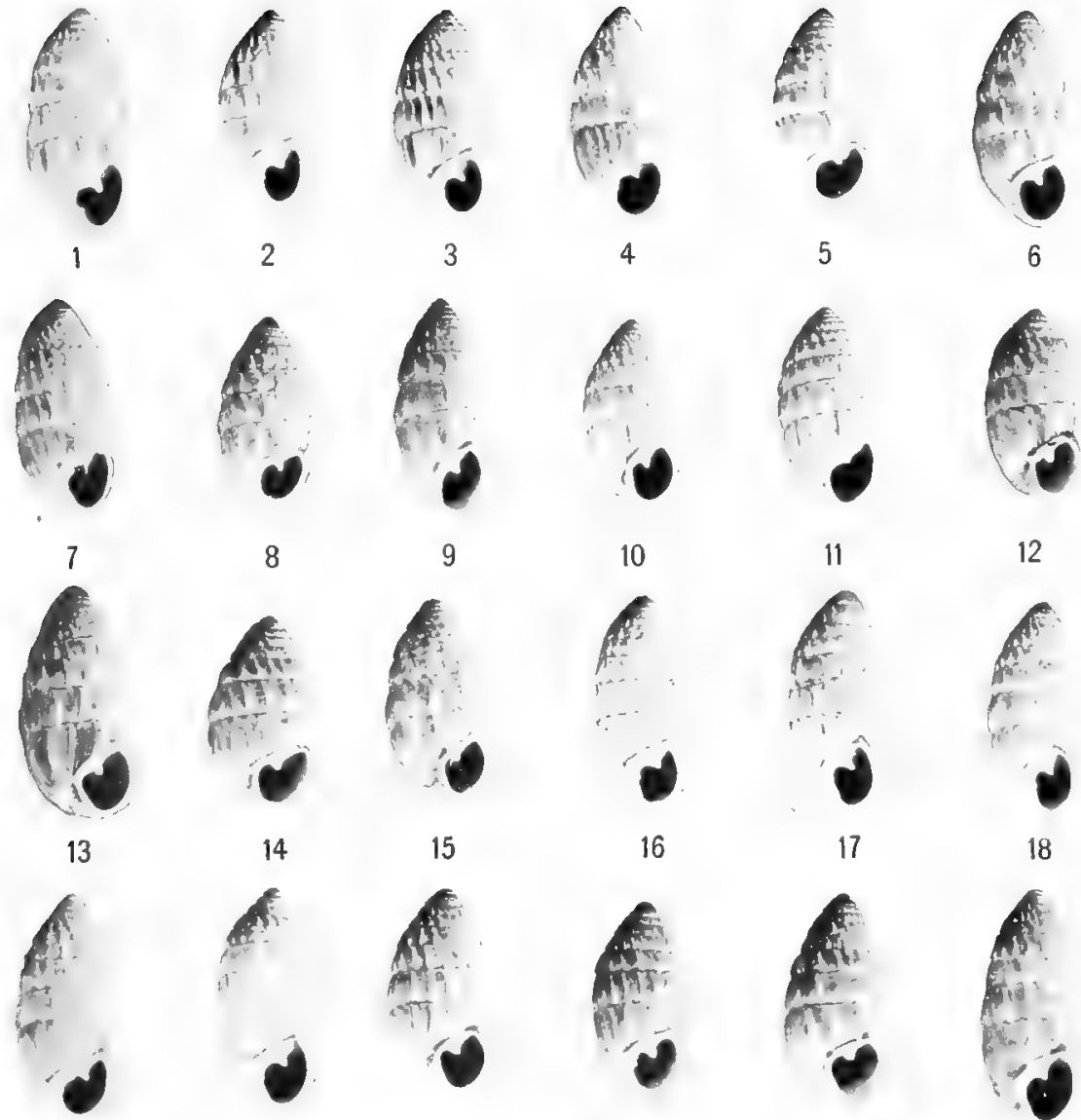

18
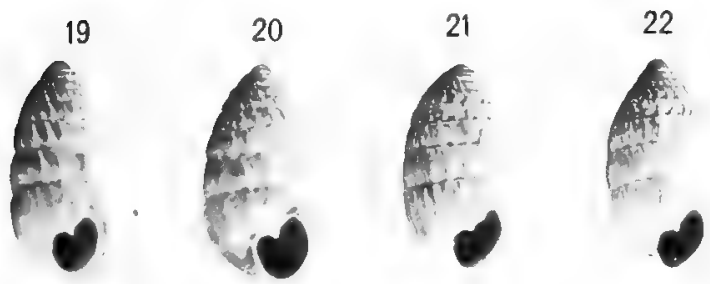

23

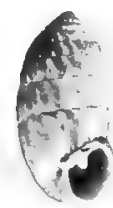

12
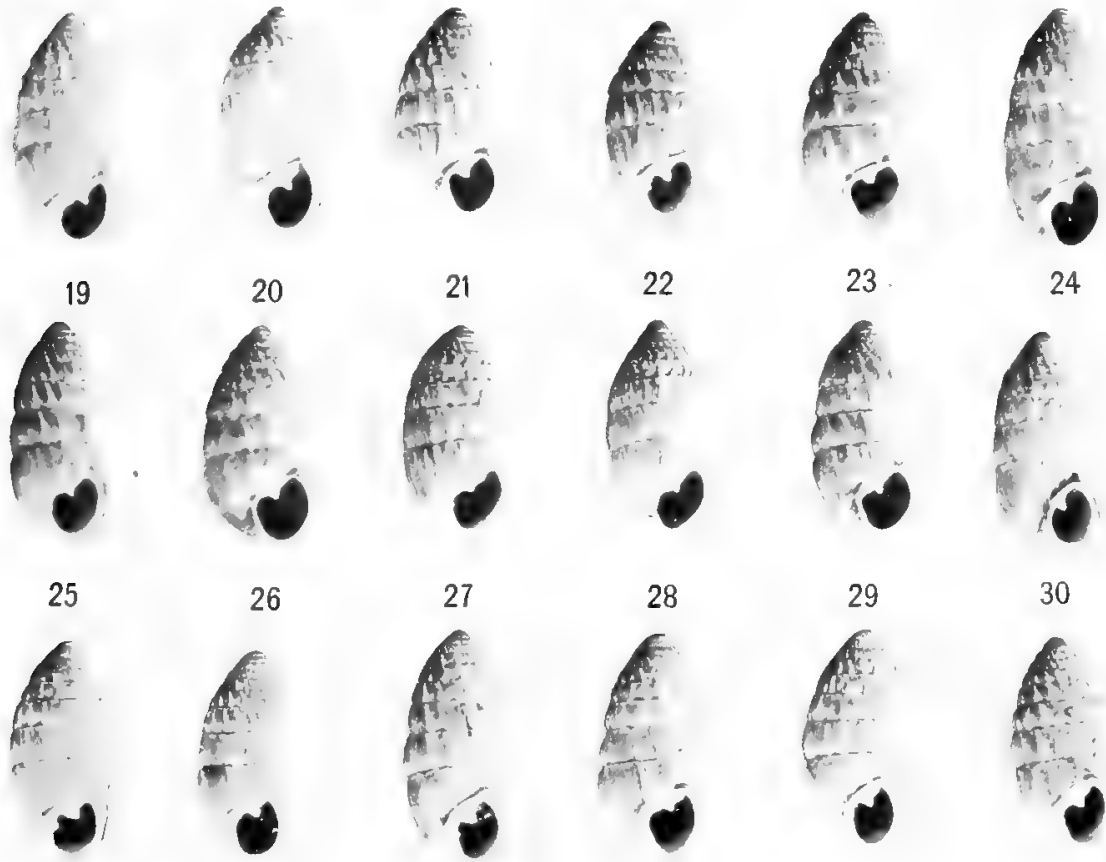

31 32

FIGS, 1-36. First generation of Florida-grown Cerion viaregis from Colony G on Loggerhead Key, 1916. 

BARTSCH

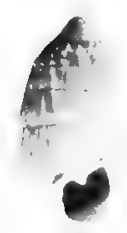

37

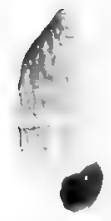

43

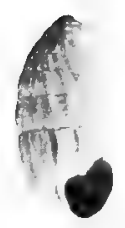

49

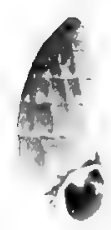

55
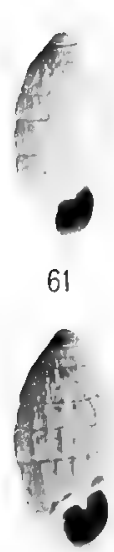

67

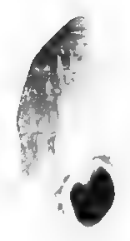

33

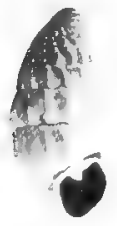

44

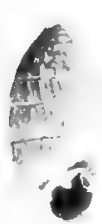

50
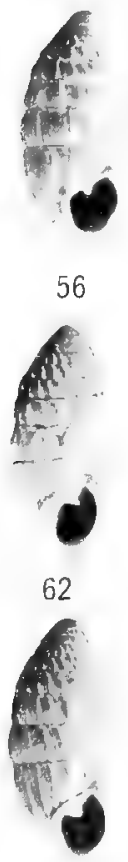

68

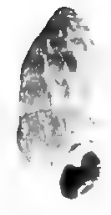

30
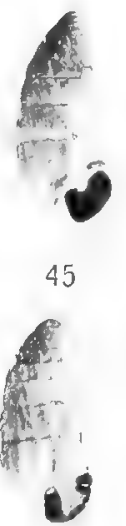

51

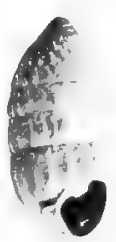

57
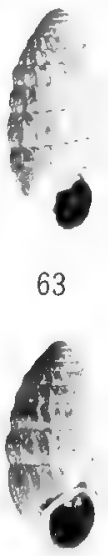

69

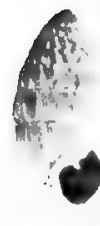

40
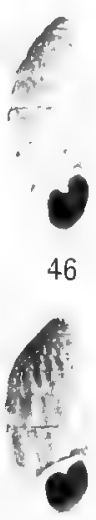

52

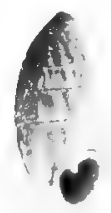

58

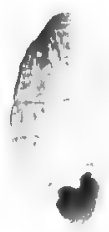

64

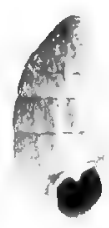

70

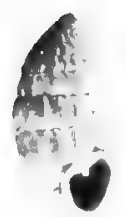

41

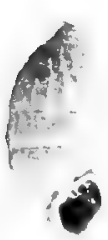

42
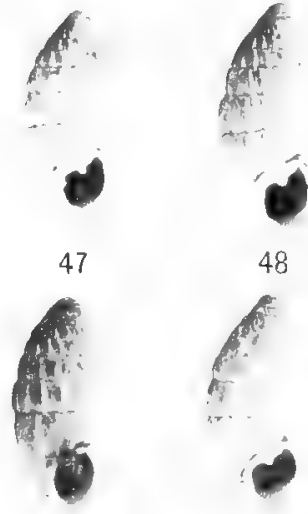

53
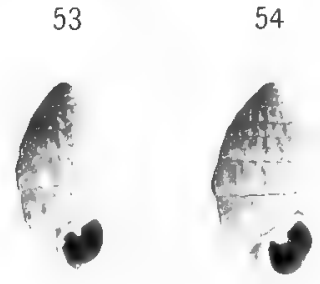

59

60
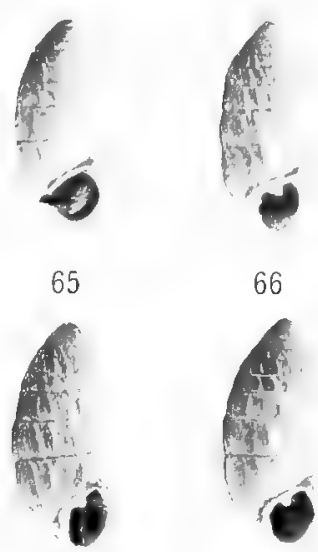

72

Figs. 37-72. First generation of Florida-grown Cerion viaregis from Colony G on Loggerhead Key. 1916. 


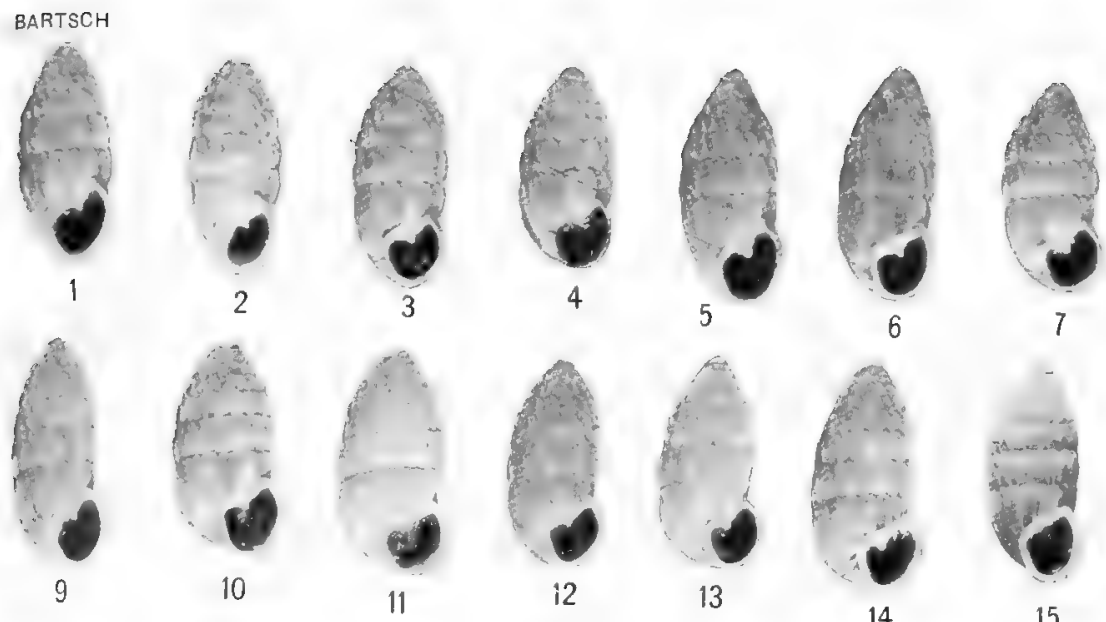

PLATE 28
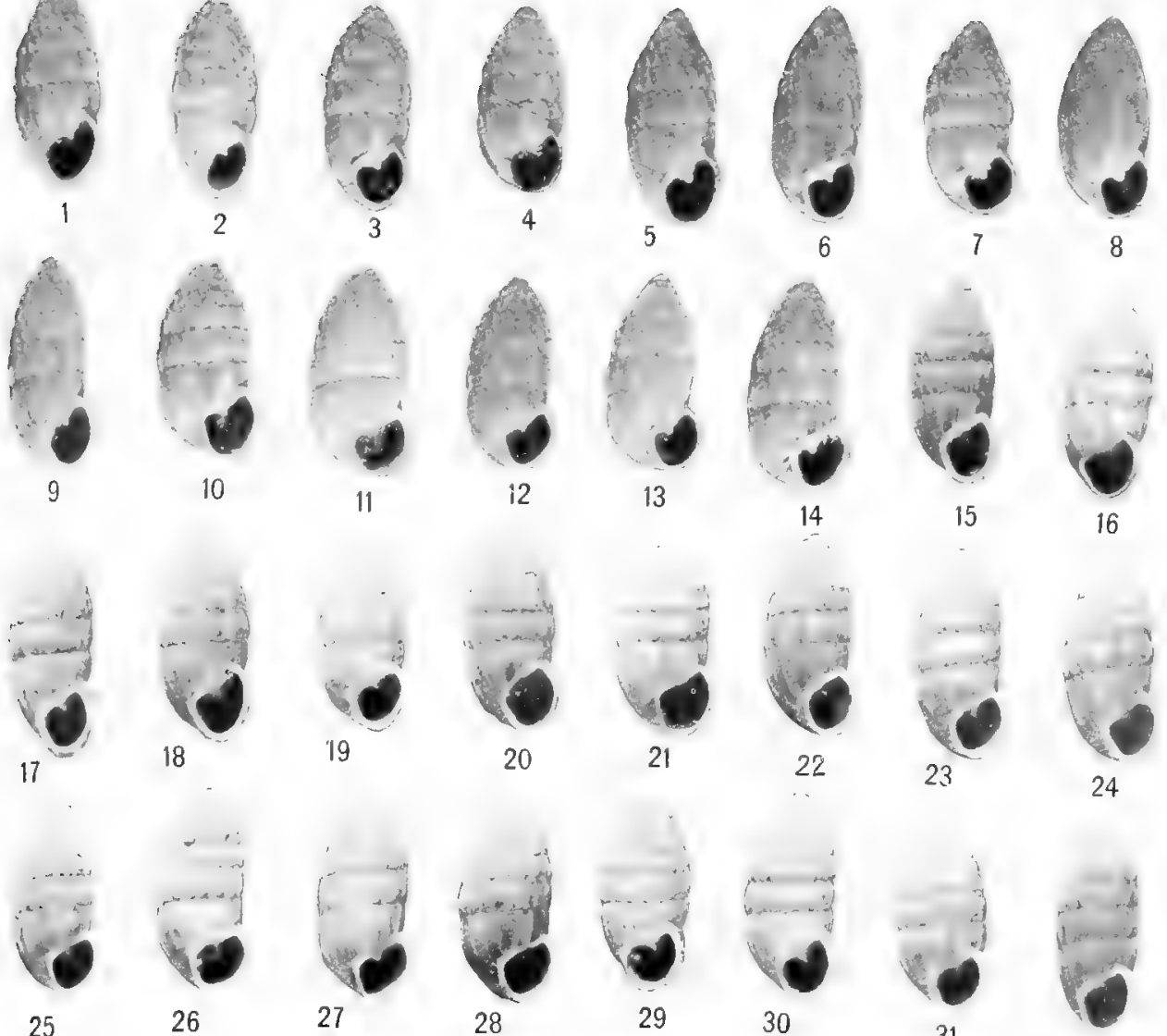

25

26

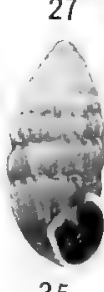

33

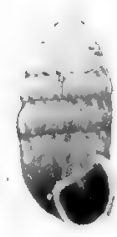

34

35
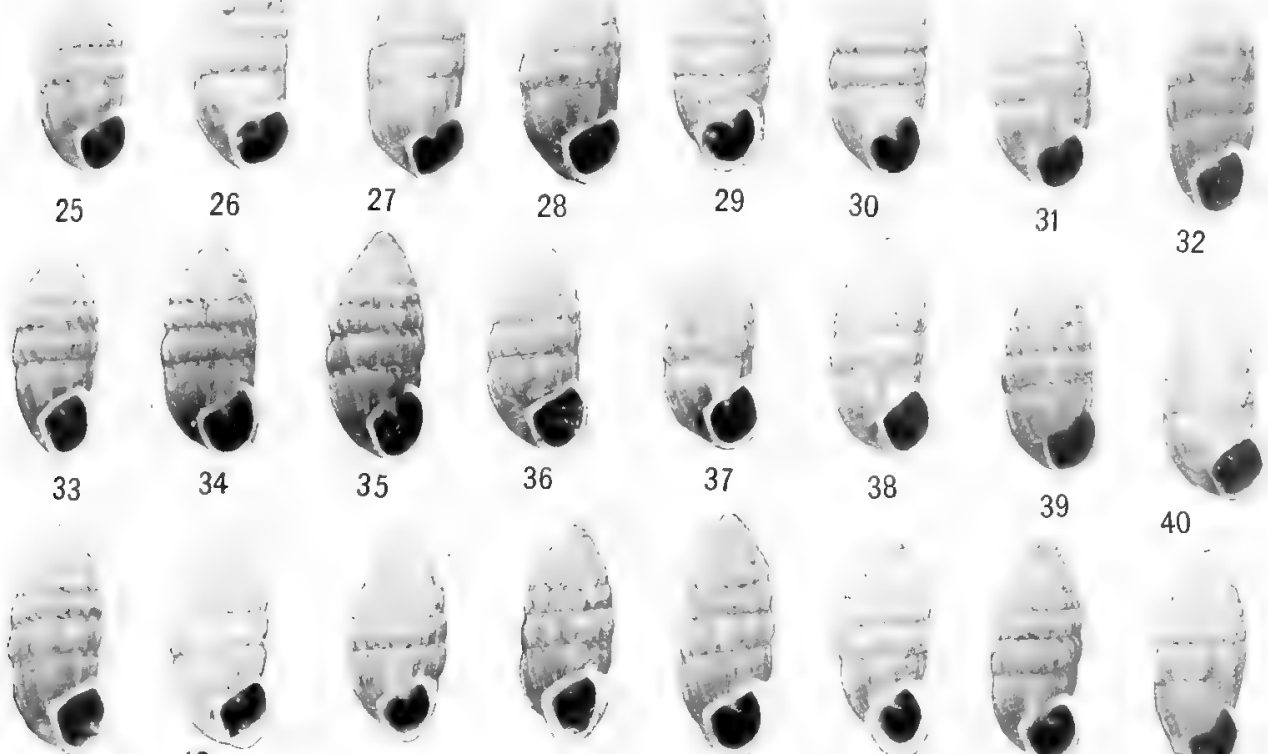

41
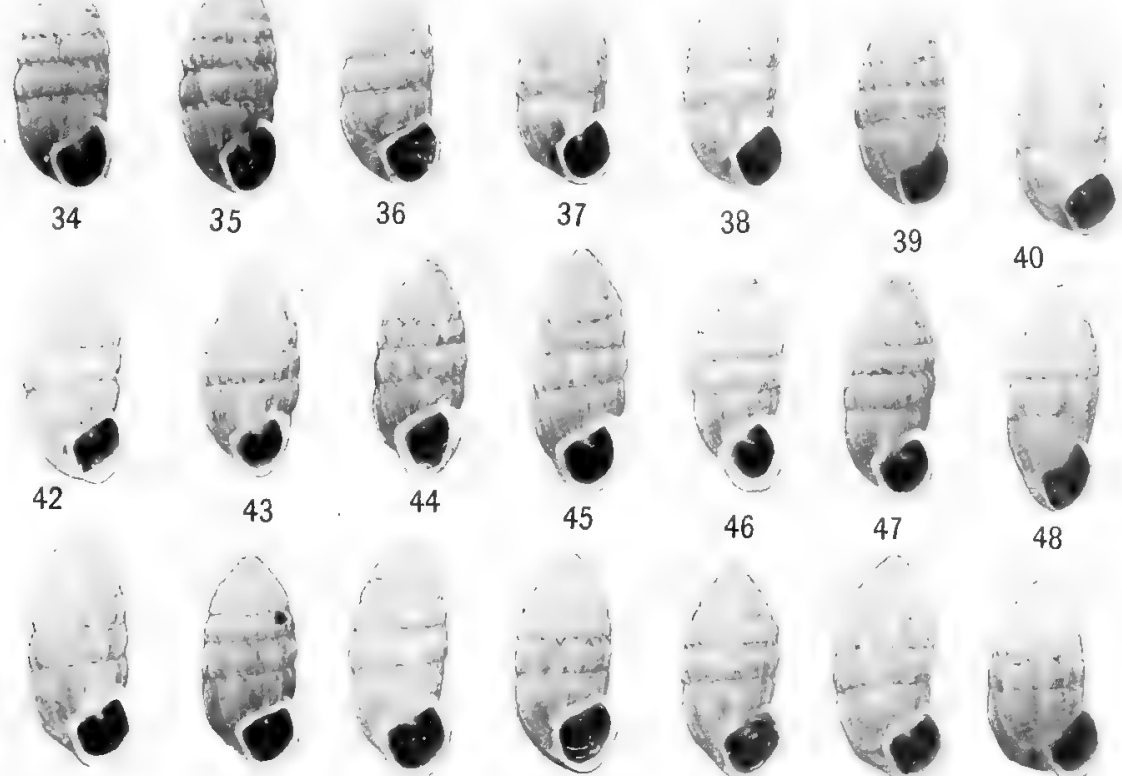

49
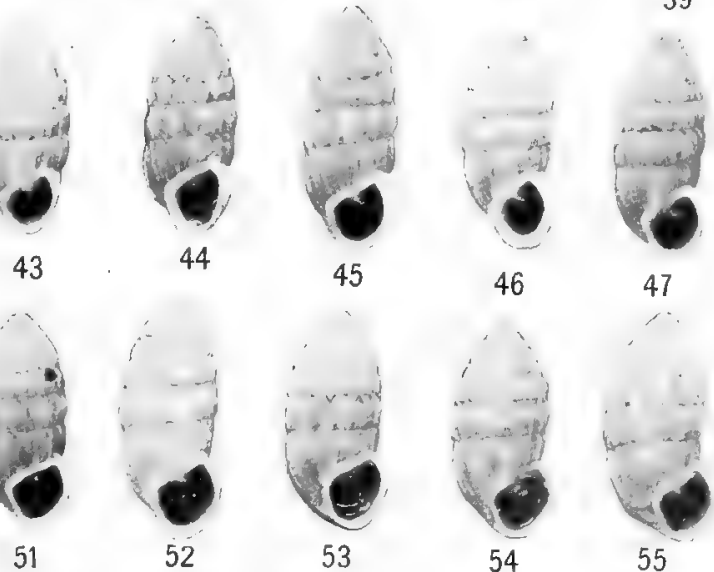

53

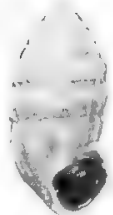

54

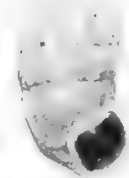

55

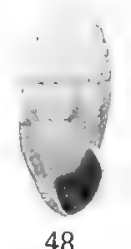

48

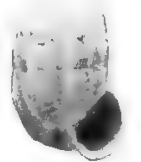

56

FIGs. 1-56. Eecond generation of Florida-grown Cerion viaregis from Colony $\mathrm{K}$ on Loggerhead Key. 



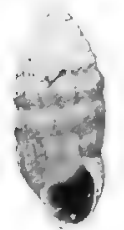

57

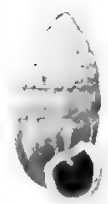

64
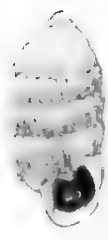

71

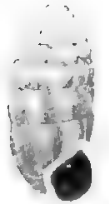

77

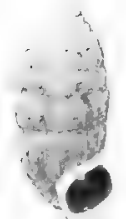

83

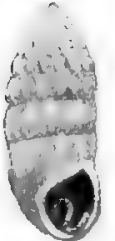

89

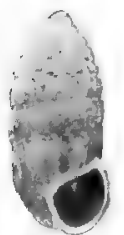

95

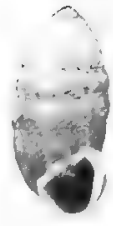

58

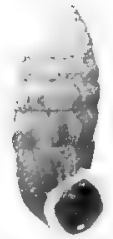

65
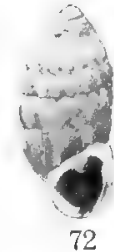

72

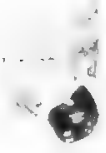

78

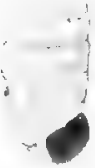

84

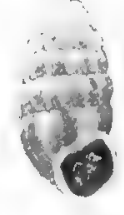

90

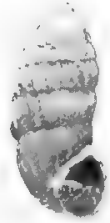

96

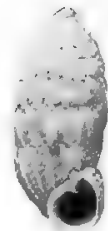

59

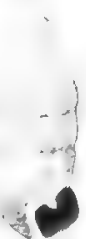

66

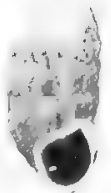

60

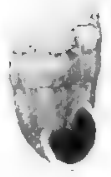

61

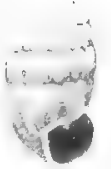

69

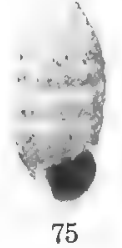

74

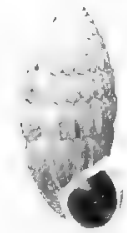

79

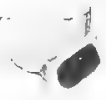

85

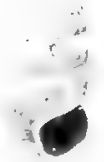

80

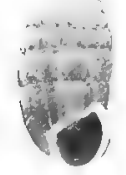

86

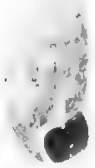

81

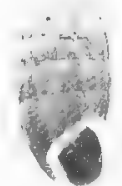

87
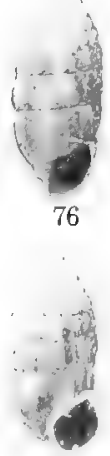

82
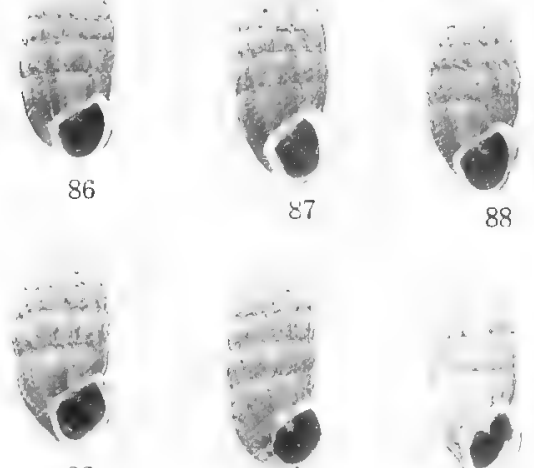

92

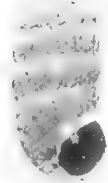

93
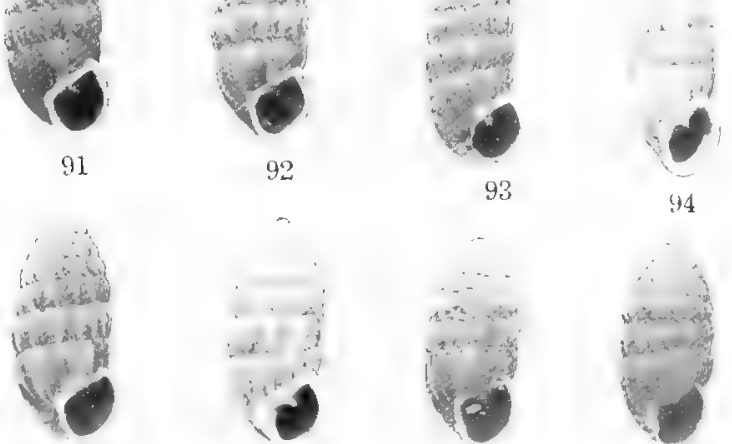

97

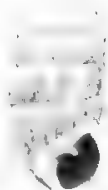

98

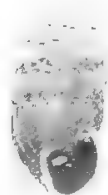

99

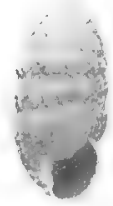

100

FIgs. 57-100. Second generation of Florida-grown Cerion viaregis from Colony $\mathrm{I}$ on Loggerhead Key. 



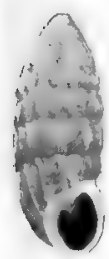

1

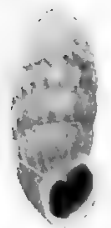

9

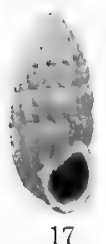

17

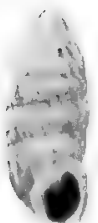

25

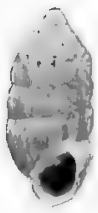

32

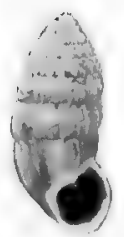

39

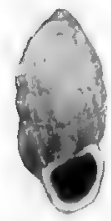

46
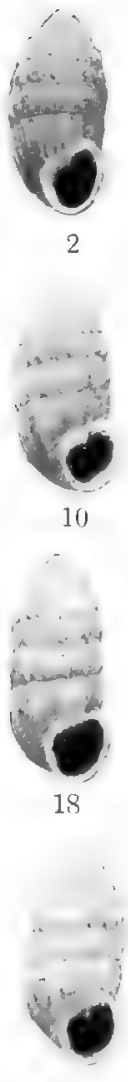

26

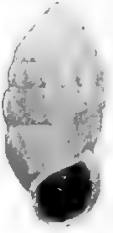

33

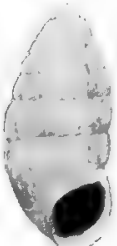

40

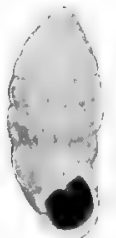

47
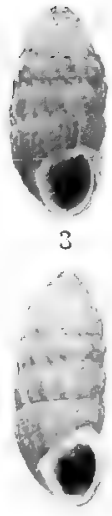

11

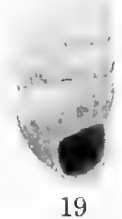

19
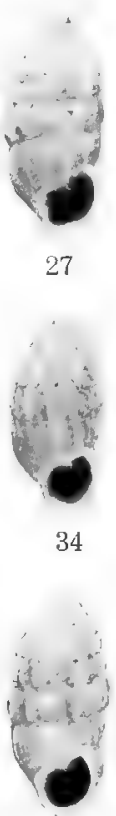

41

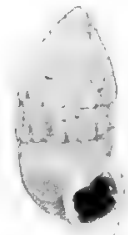

48
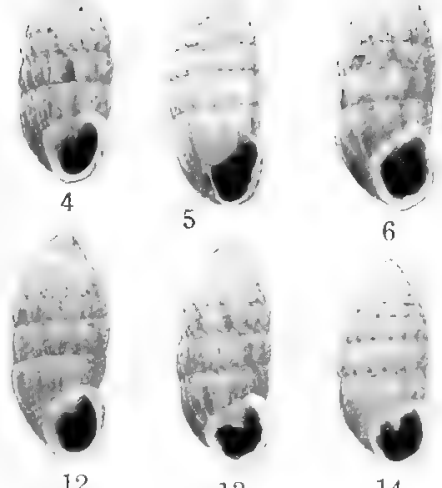

12

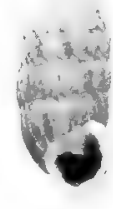

13

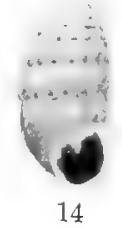

14
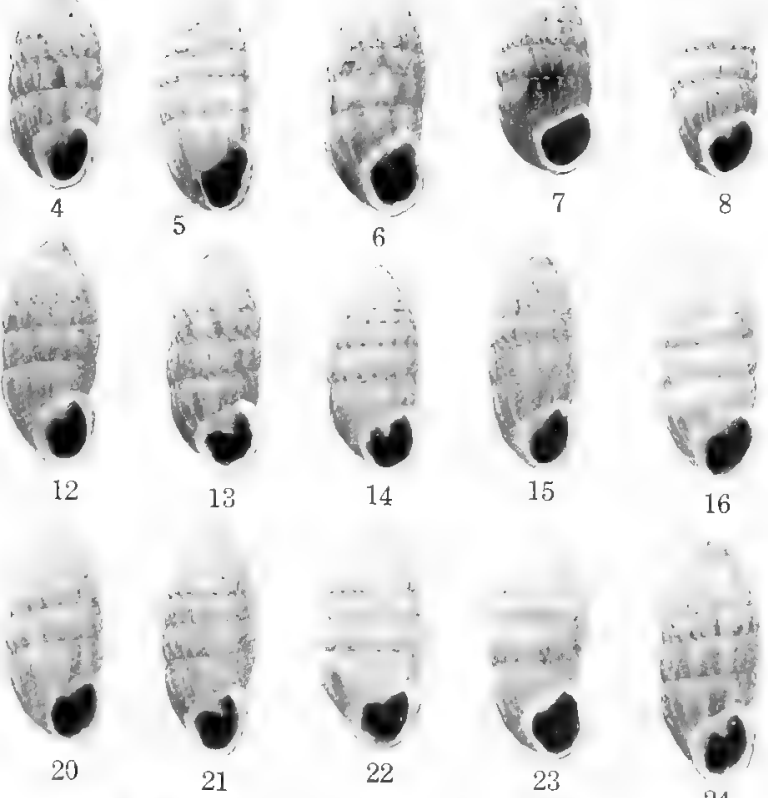

24
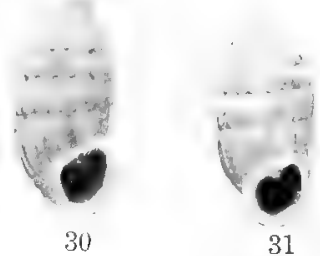

28

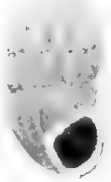

29

31
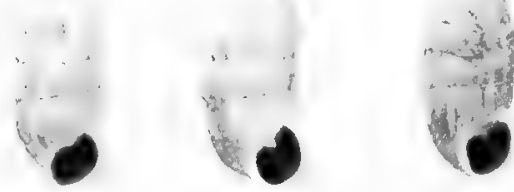

36

37

38

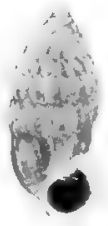

44

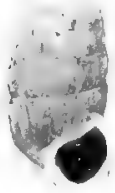

45

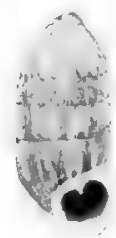

50

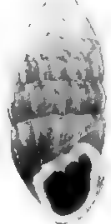

51

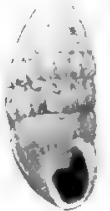

52

FIGs. 1-52. Second generation of Florida-grown Cerion viaregis from Colony $M$ on Loggerhead Key. 



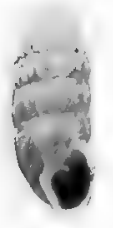

53

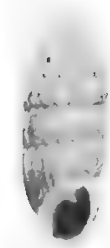

61

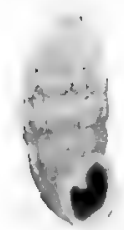

69

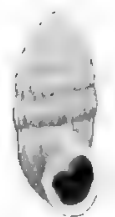

77

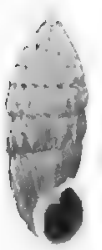

85

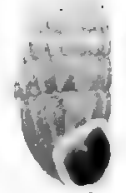

54

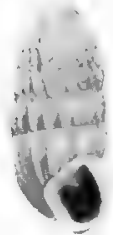

62
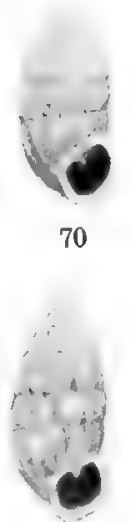

78

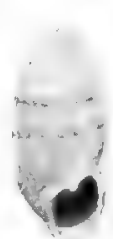

86

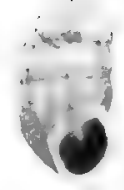

55
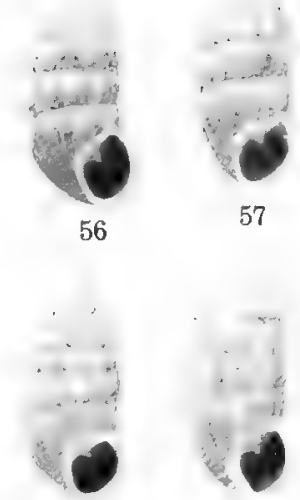

65
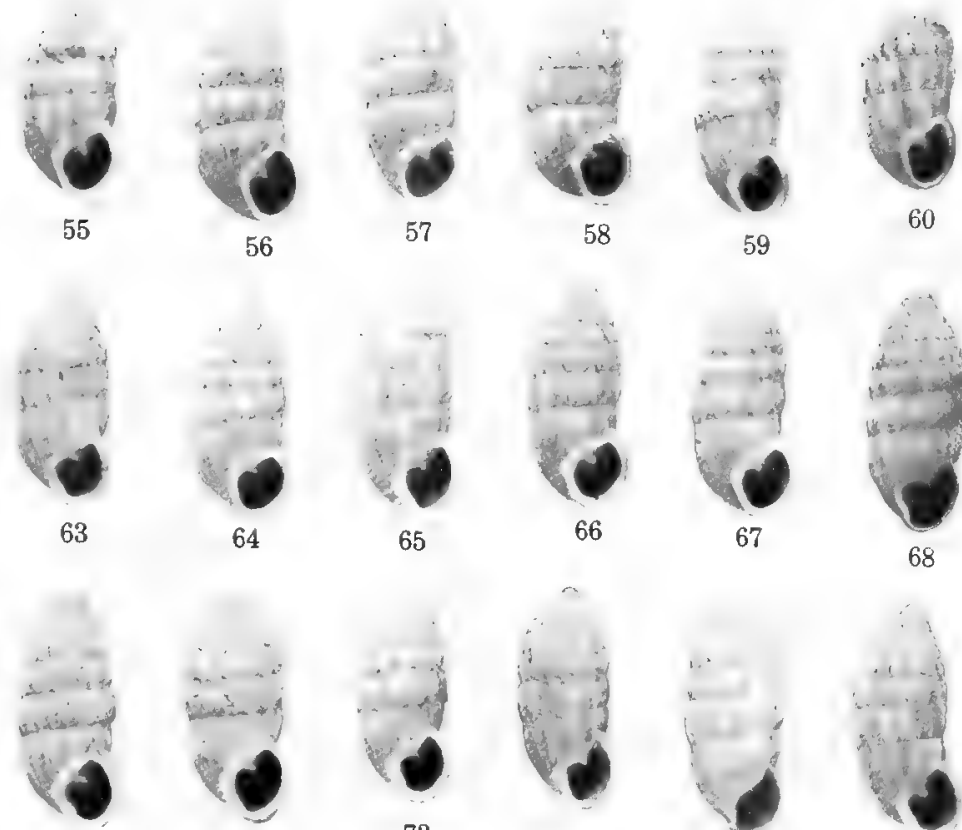

71

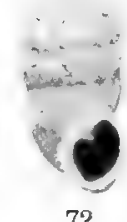

72

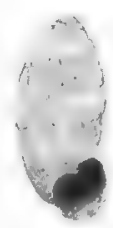

79

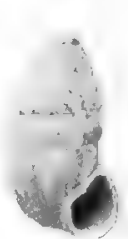

80
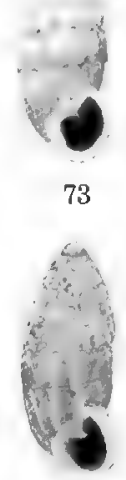

81

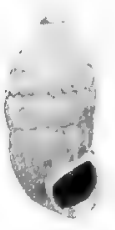

89

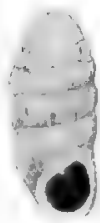

94

87
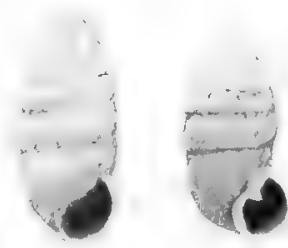

88

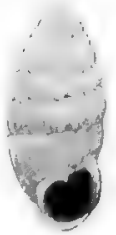

96

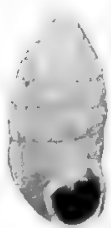

95

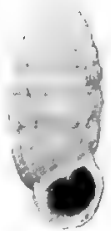

97

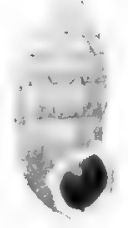

66
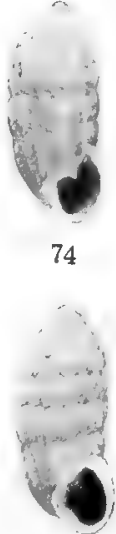

82

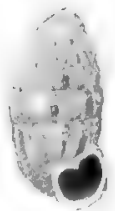

90

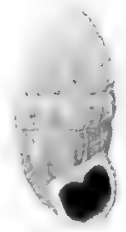

98

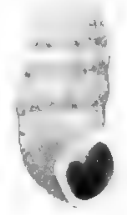

67
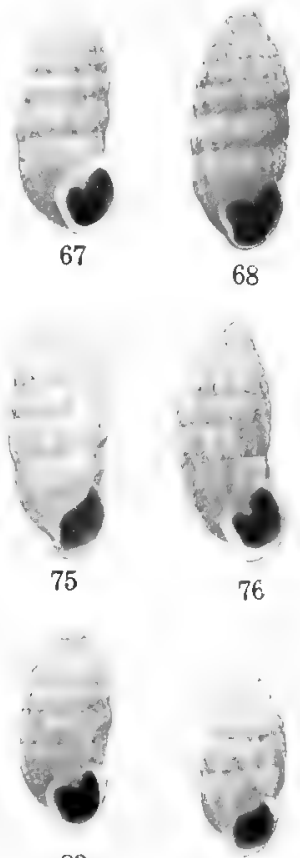

83
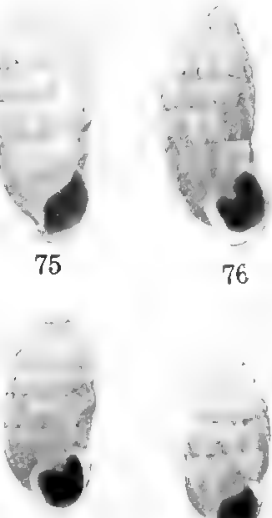

84

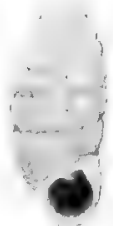

91

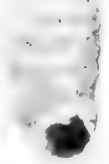

92

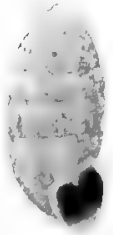

99

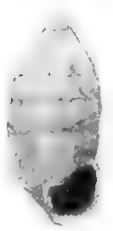

100

FIGS, 53-100. Second generation of Florida-grown Cerion viaregis from Colony M on Loggerhead Key. 


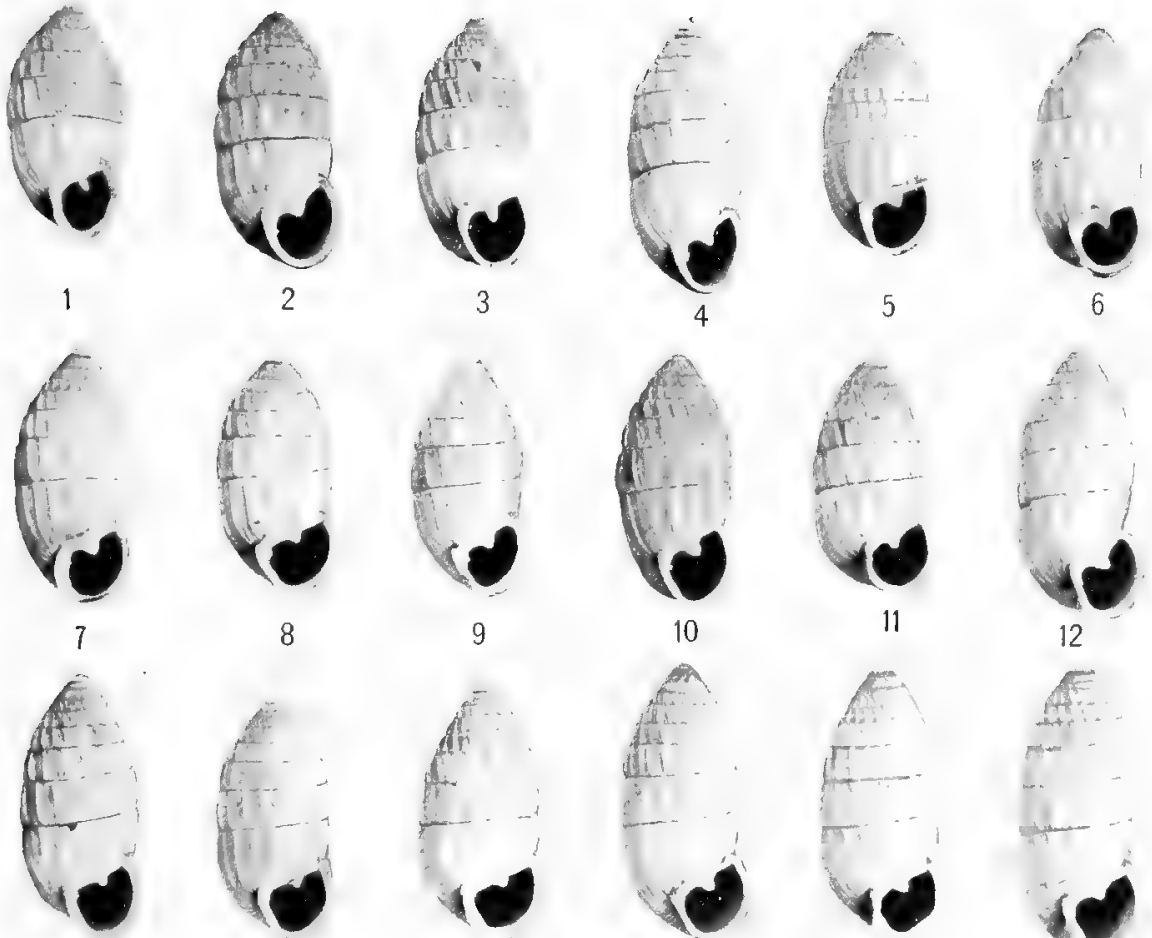

8

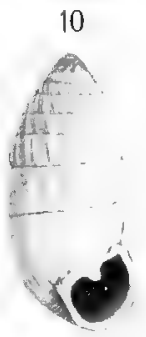

11

12

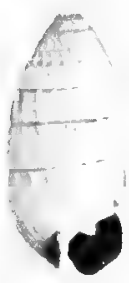

15

16
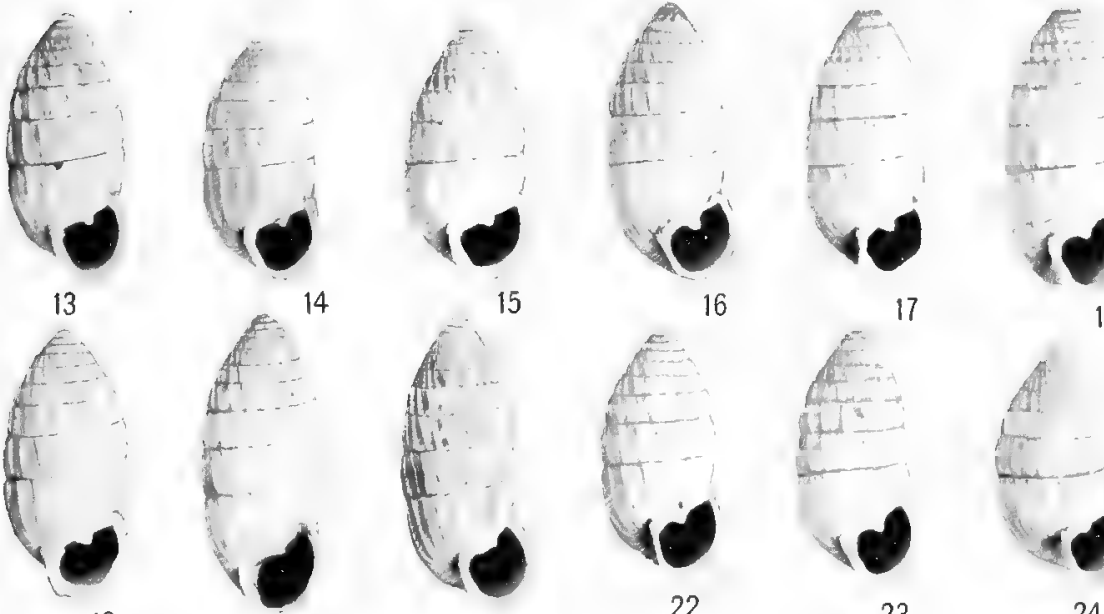

17

18

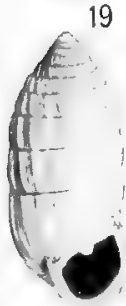

20
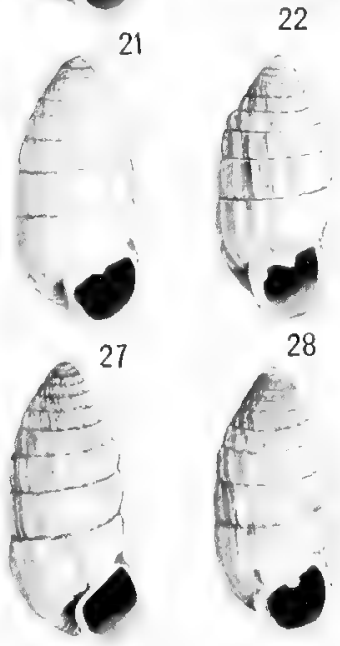

28
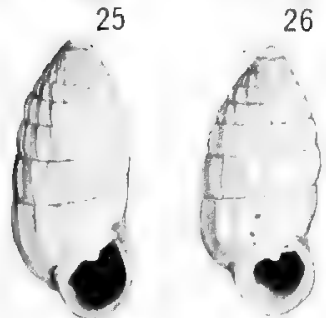

32
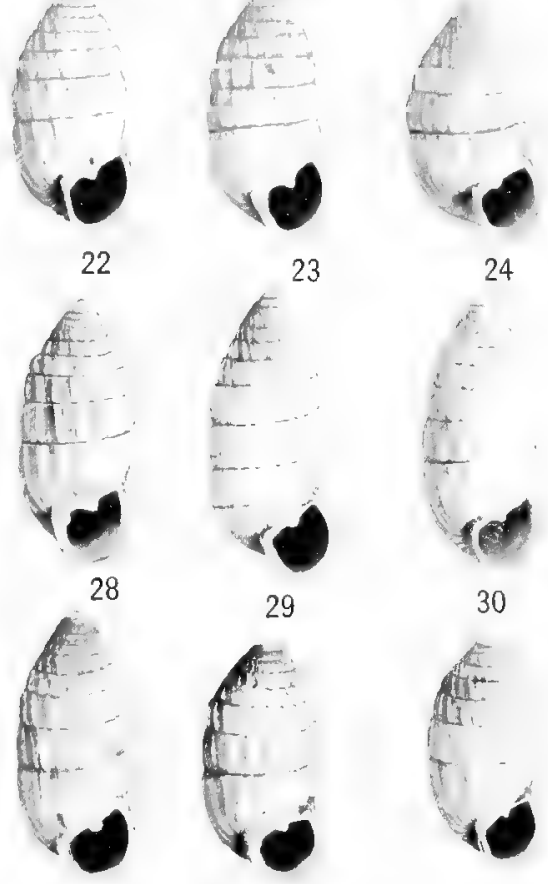

30

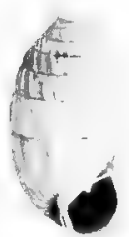

FIGs. 1-36. Check series of Cerion casablance. No. 13 type of Cerion casablancee. 



\section{BARTSCH}
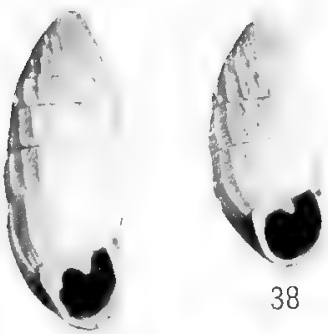

38

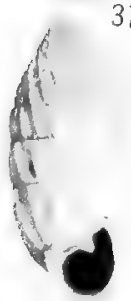

43

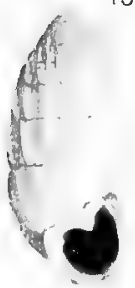

49

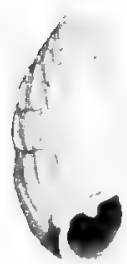

55
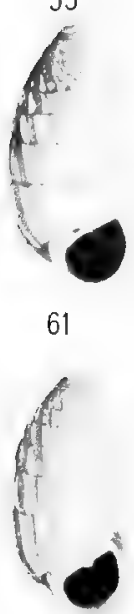

67

44

50

62
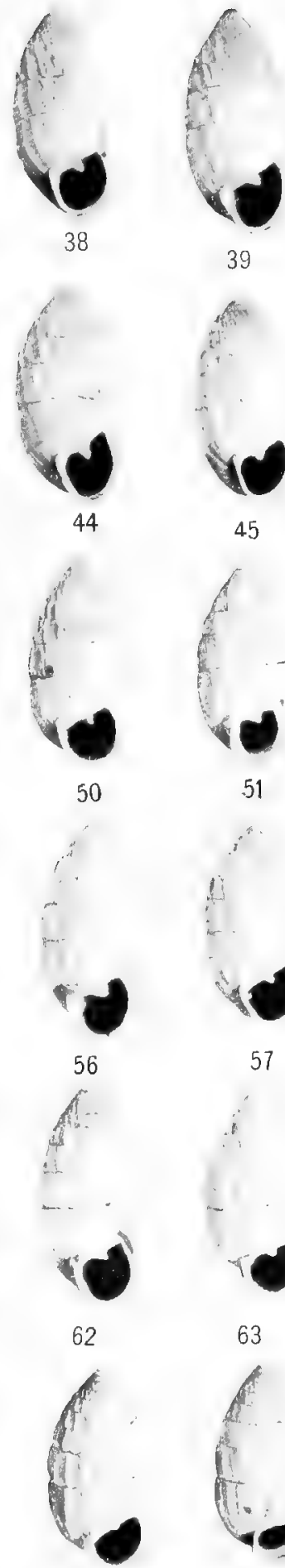

68
39

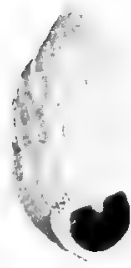

40

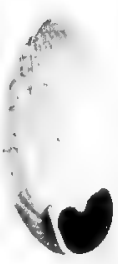

45
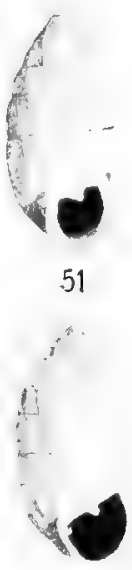

57

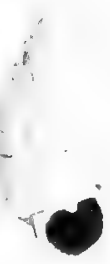

63

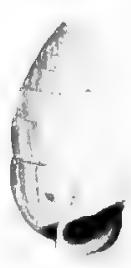

69

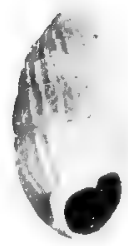

46

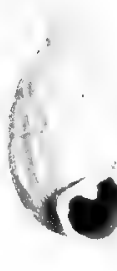

52
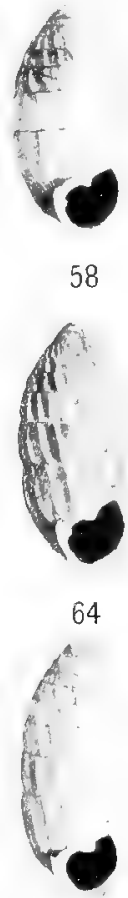

70

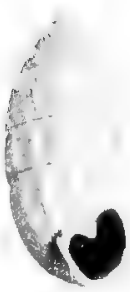

41
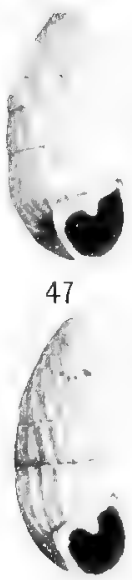

53
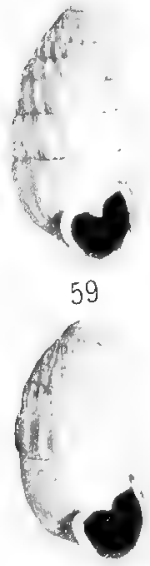

65

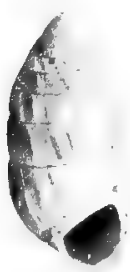

71
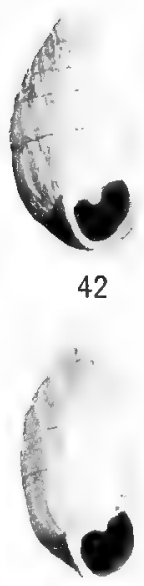

48
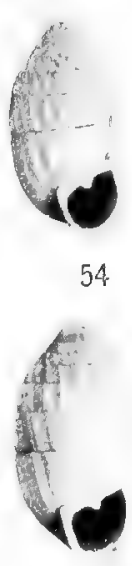

60

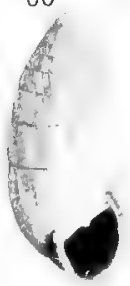

66

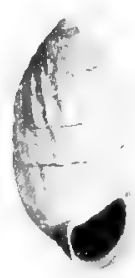

Figs. 37-72. Check series of Cerion casablance. 

BARTSCH
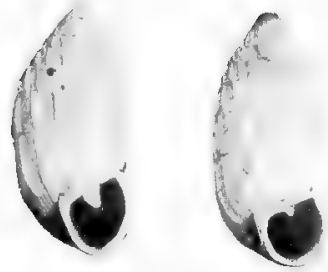

74
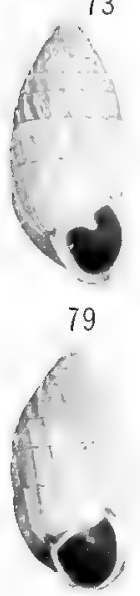

28

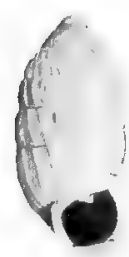

91

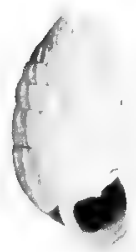

97

80

86

92

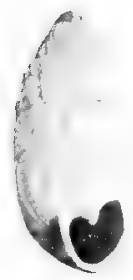

75
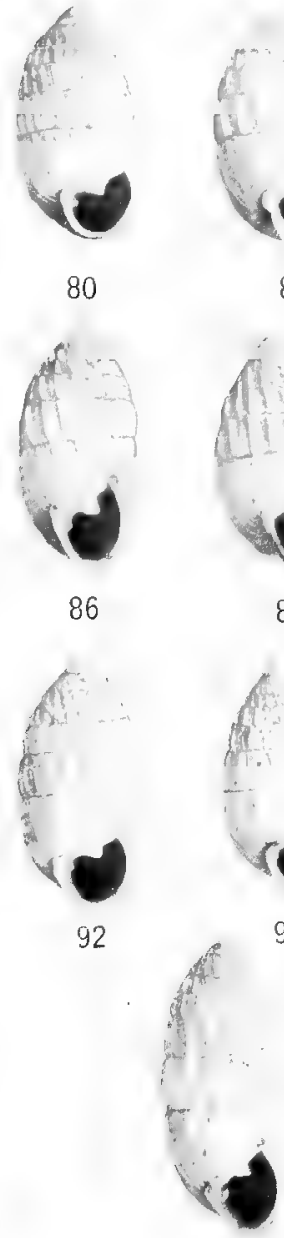

86

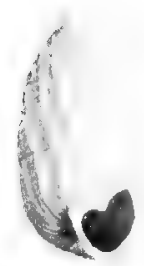

76

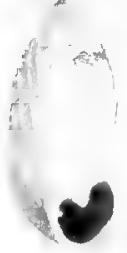

82

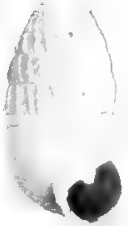

88

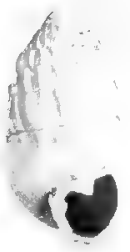

94

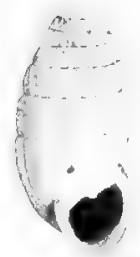

99

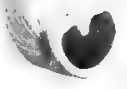

77

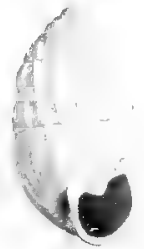

83

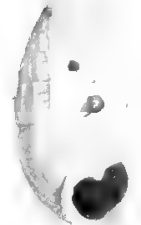

89

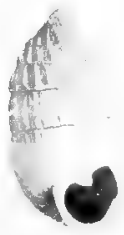

95
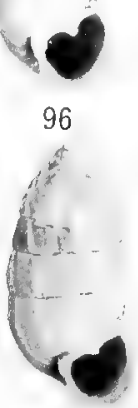

100

FIGs. 73-100. Check series of Cerion casablance. 



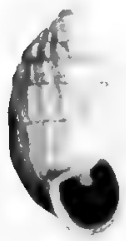

1

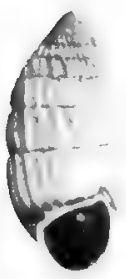

6

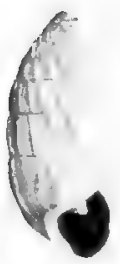

11

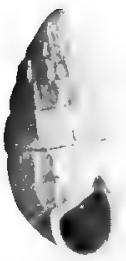

16

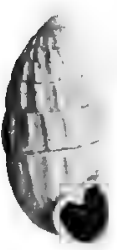

21

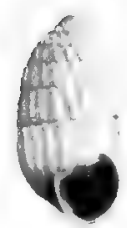

2

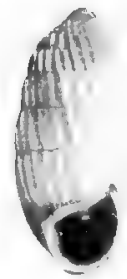

7

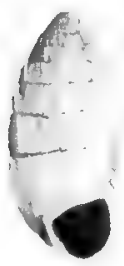

12

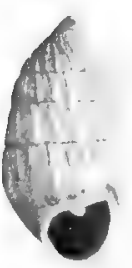

17

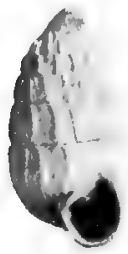

22

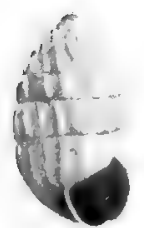

3

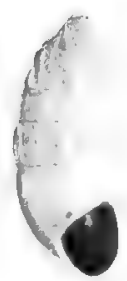

8

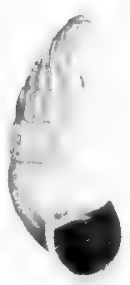

13

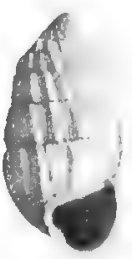

18

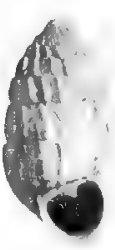

23

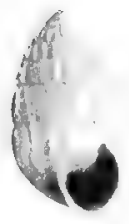

4

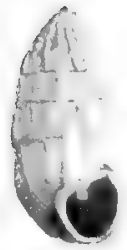

5

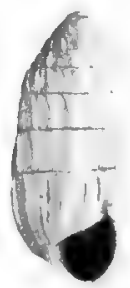

9

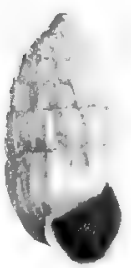

10

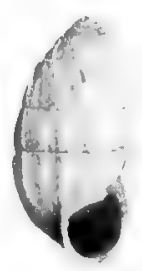

14

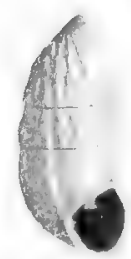

19

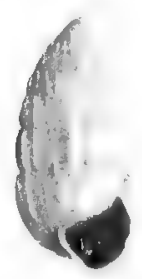

15

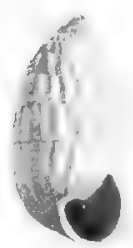

20

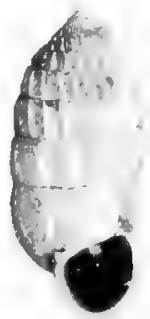

24

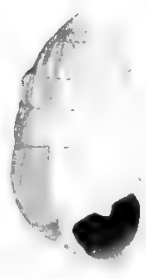

25

Figs. 1-23. First generation of Florida-grown Cerion casablancre from the First Ragged Key north of Sands Key.

FIGs. 24 and 25. Second generation of Florida-grown Cerion casablance from the First Ragged Fey north of Sands Key. 



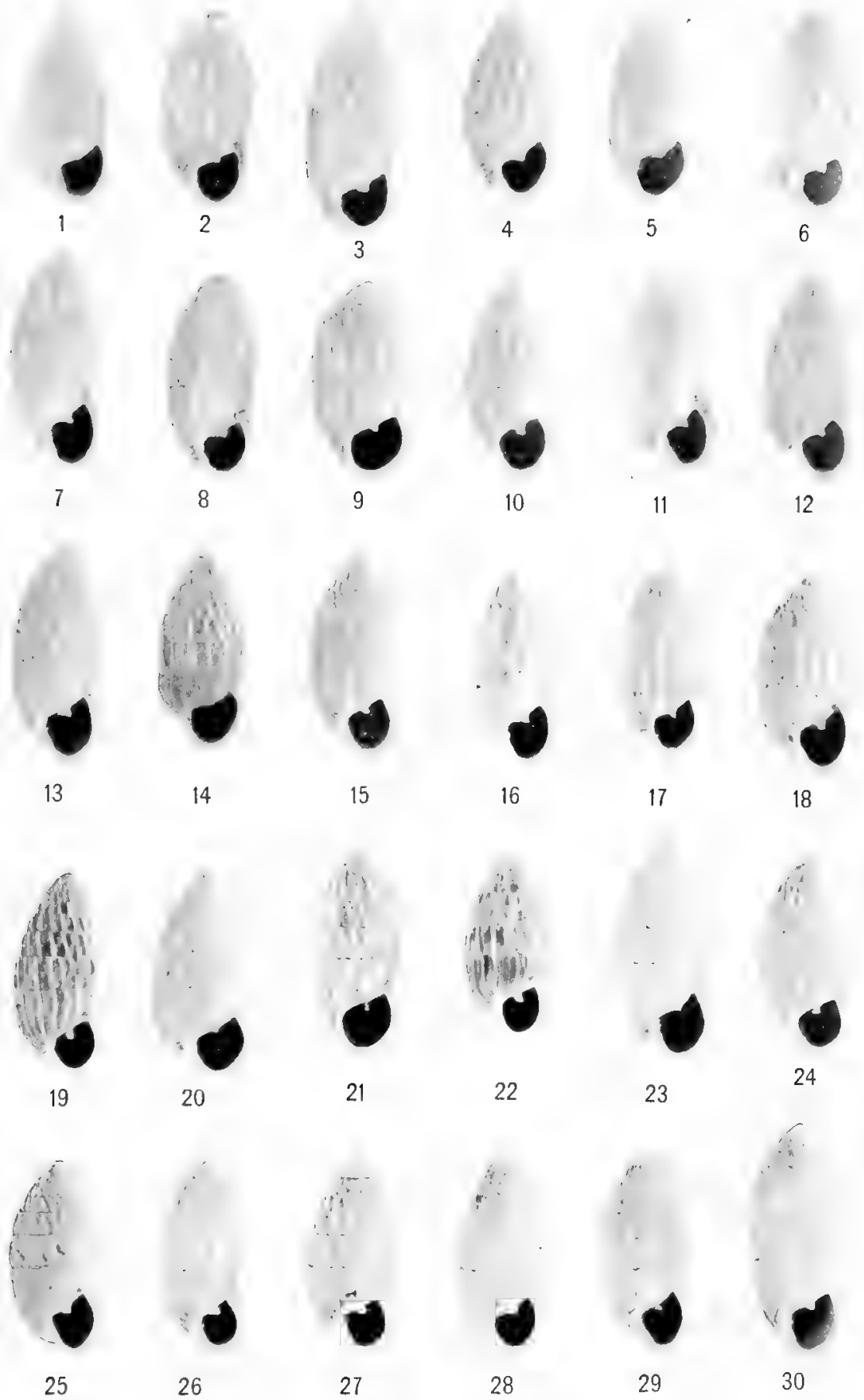

Figs. 1-30. First generation of Florida-grown Cerion casablancee from Bahia Honda Key. 



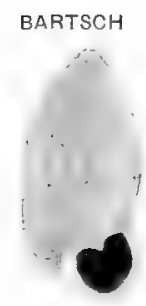

31

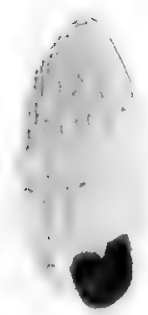

37

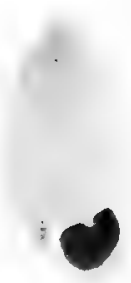

43

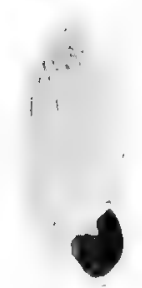

48

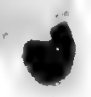

32

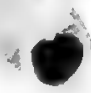

38

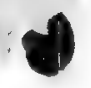

33

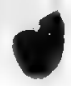

39

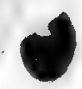

34

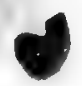

40

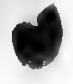

35

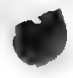

41

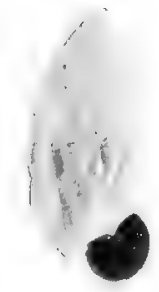

45

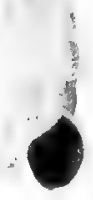

46
PLATE 37

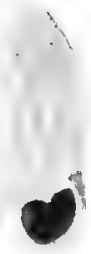

36

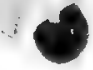

42

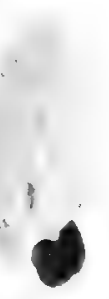

44

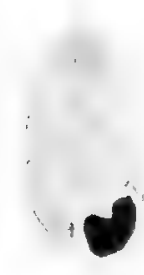

49

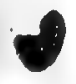

50

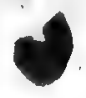

47

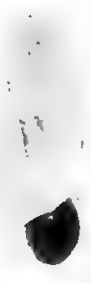

53

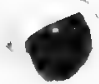

54

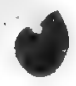

55
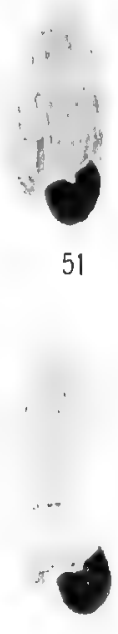

56

Figs. 31-56. First generation of Florida-grown Cerion casablancee from Bahia Honda Kiey. 


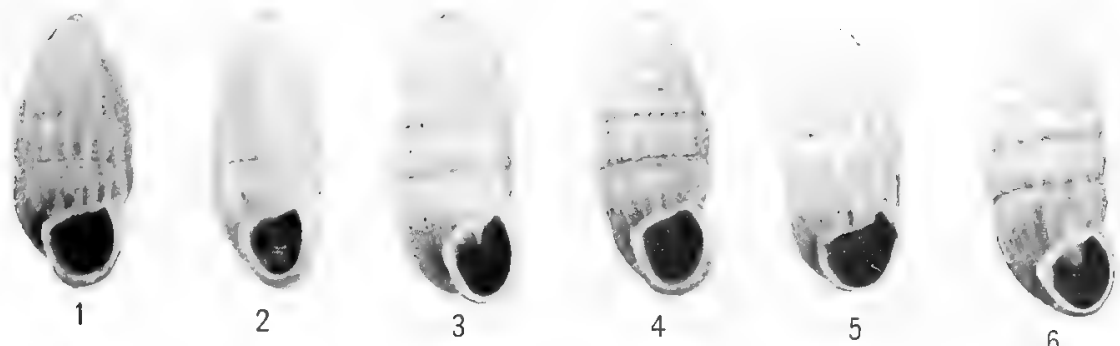

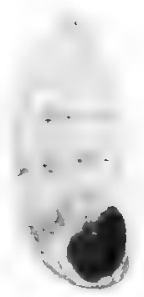

7

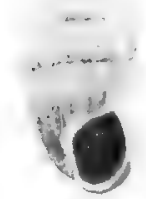

8

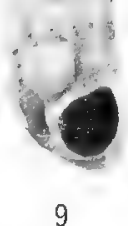

9

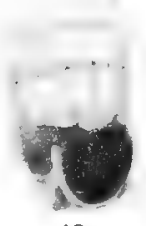

10

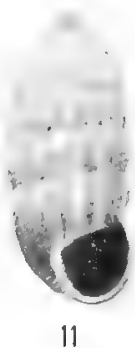

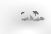

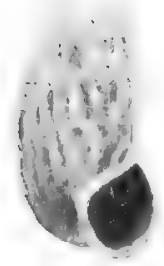

13

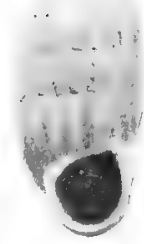

14

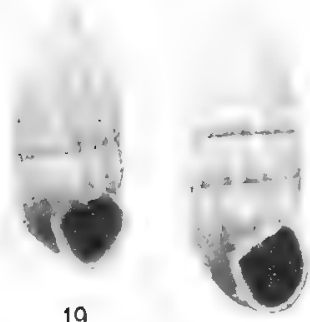

19

20

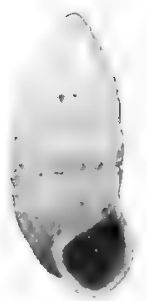

25

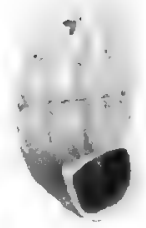

26

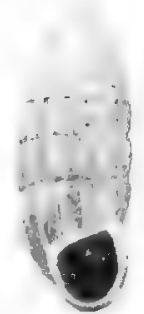

15

-

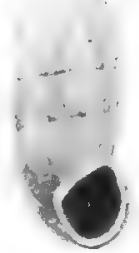

21

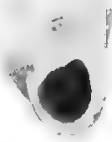

27

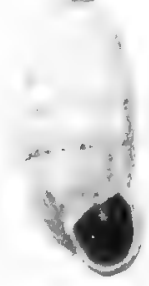

16

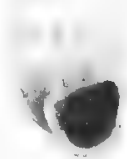

22

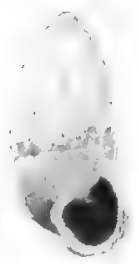

28

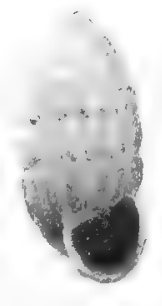

17

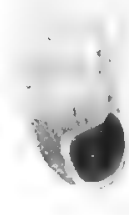

23

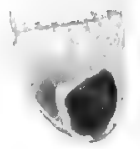

29
18

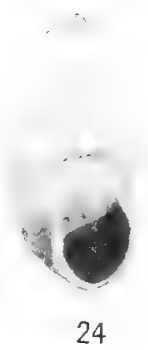

24
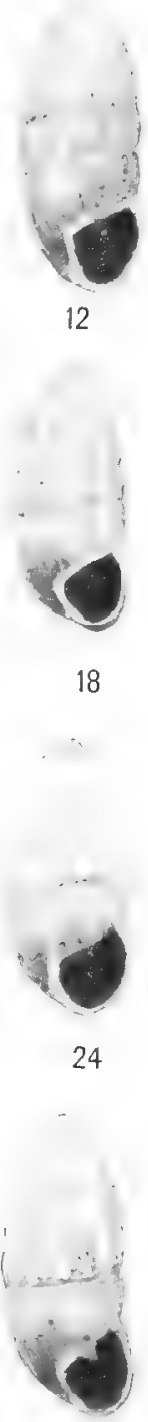

30

Figs. 1-30. First generation of Florida-grown Cerion casablance from Colony B on Loggerhead Key. 1915. 



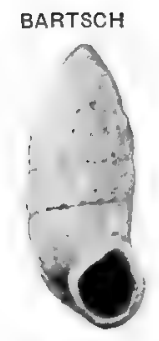

31

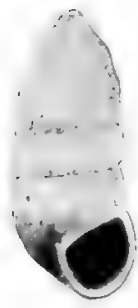

37

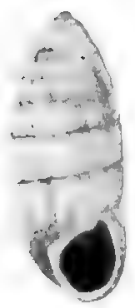

43

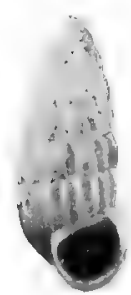

49

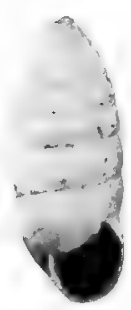

55

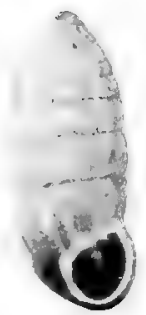

32

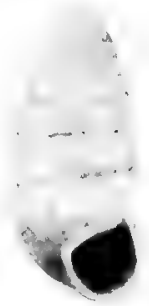

38

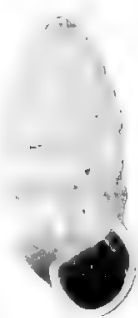

44

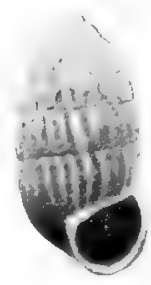

50

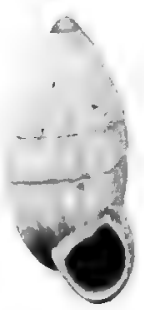

56
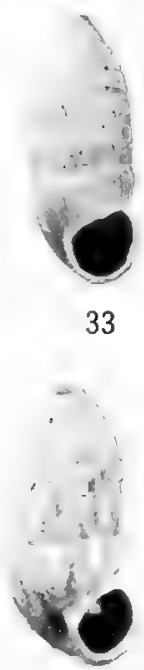

39

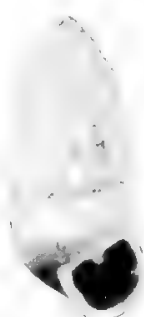

45

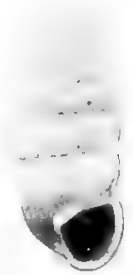

51

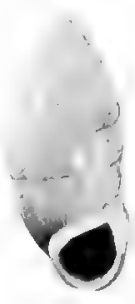

57
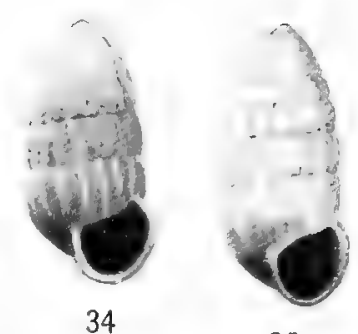

35

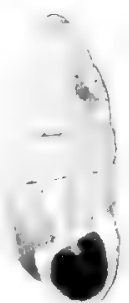

40

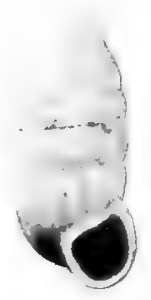

46

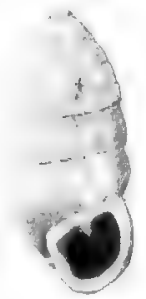

41

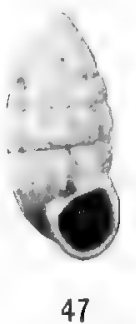

47

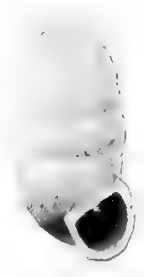

52
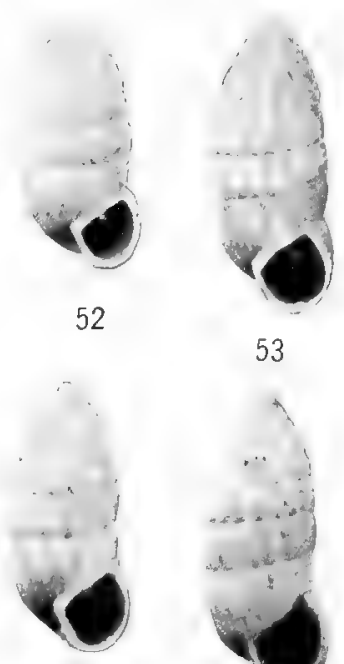

58
53

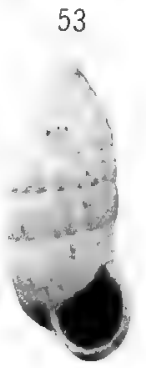

59
PLATE 39
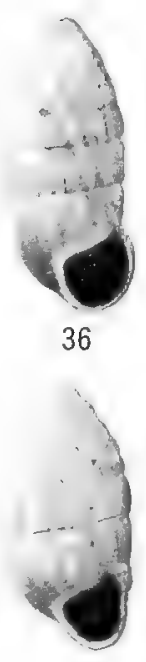

42

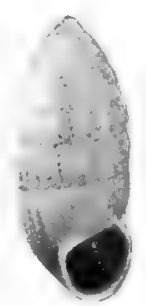

48

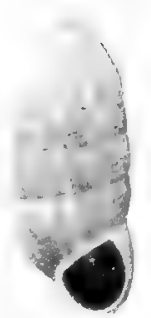

54

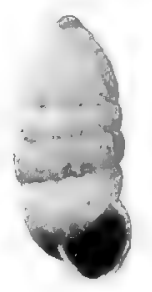

60

FrGS. 31-60. First generation of Florida-grown Cerion casablancee from Colony B on Loggerhead Key. 1915. 


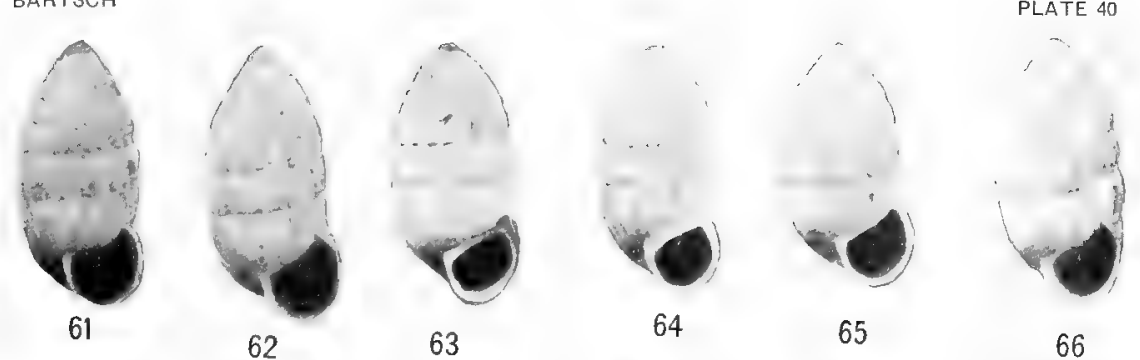

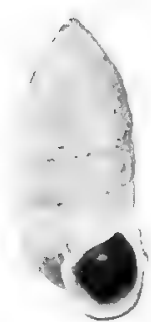

67

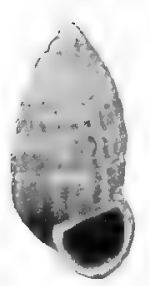

73

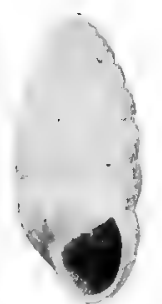

79

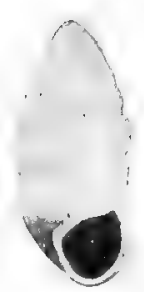

85

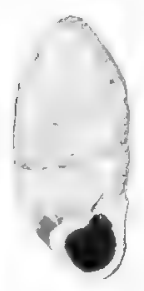

68

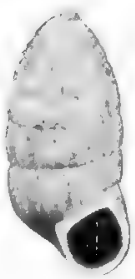

74

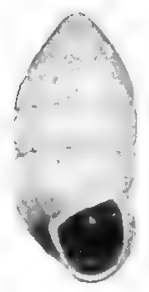

80

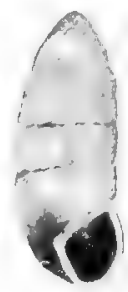

86

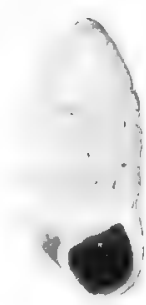

69

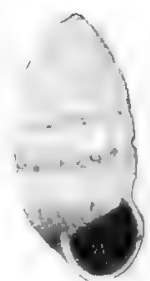

75

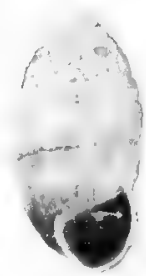

81

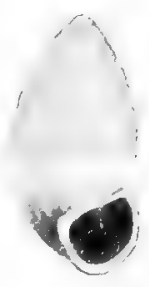

87

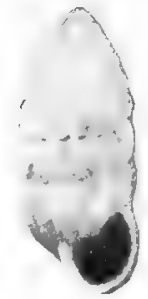

70

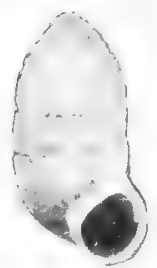

76

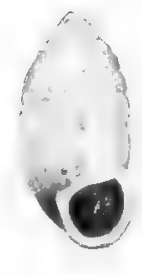

82

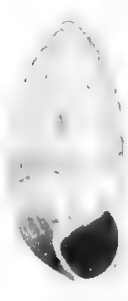

88
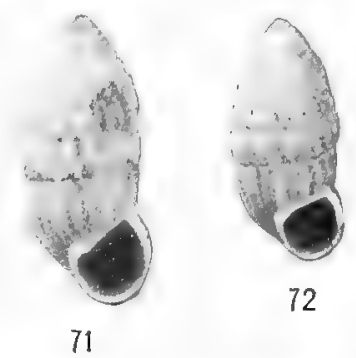

72

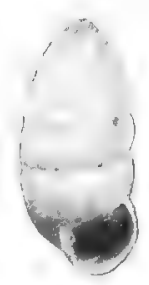

77

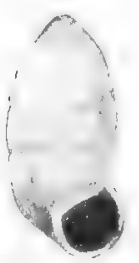

78

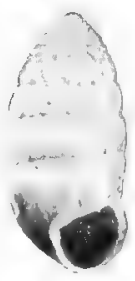

83

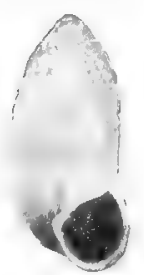

84

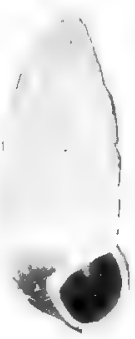

89
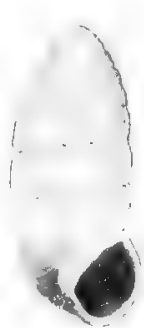

90

FIgS. 61-90. First generation of Florida-grown Cerion casablanere from Colony B on Loggerhead Key. 1915. 



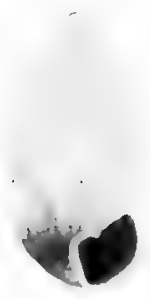

91

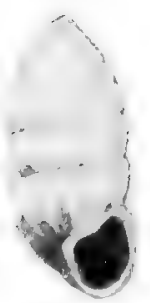

97

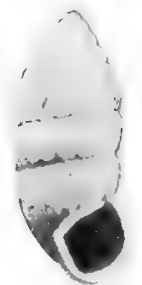

103

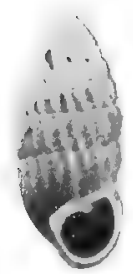

109
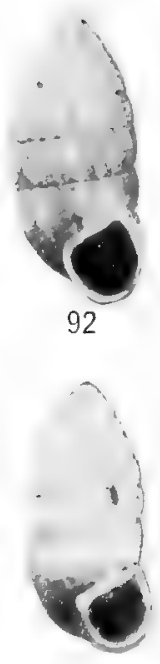

98

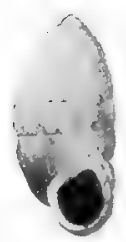

93

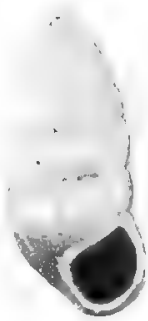

99

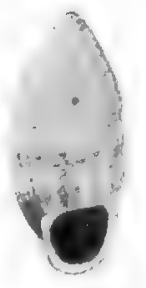

105
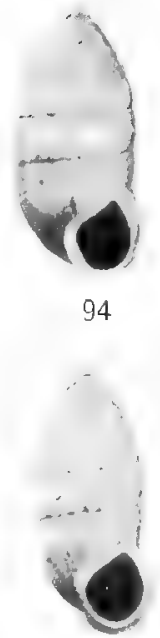

100

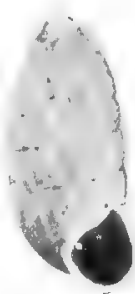

106

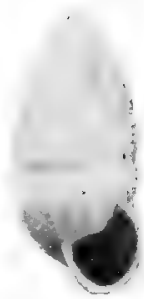

95

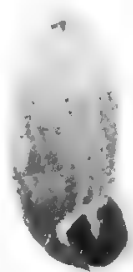

101

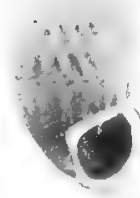

107

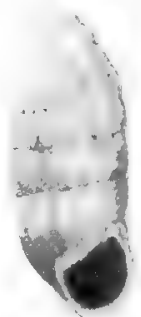

112

113
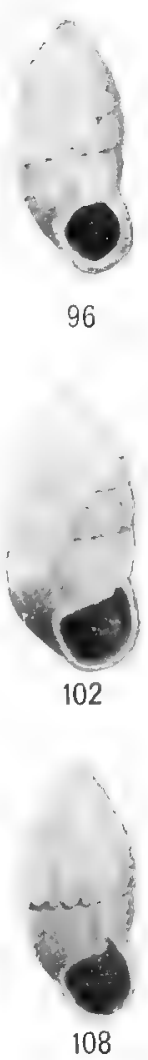

108
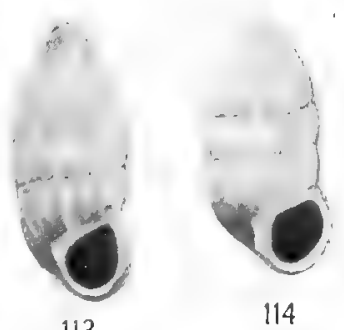

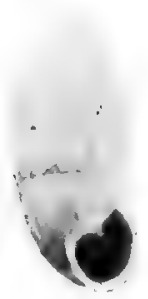

115

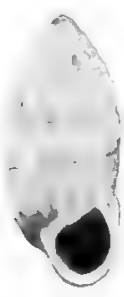

117

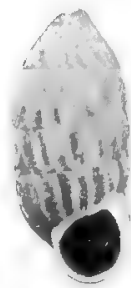

118

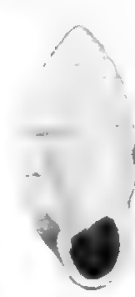

119

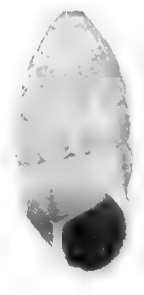

120

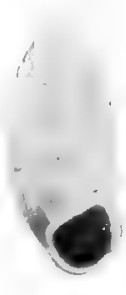

121

FiGis. 91-121. First generation of Florida-grown Cerion casablance from Colony B on Loggerhead Key. 1915. 



\section{BARTSCH}

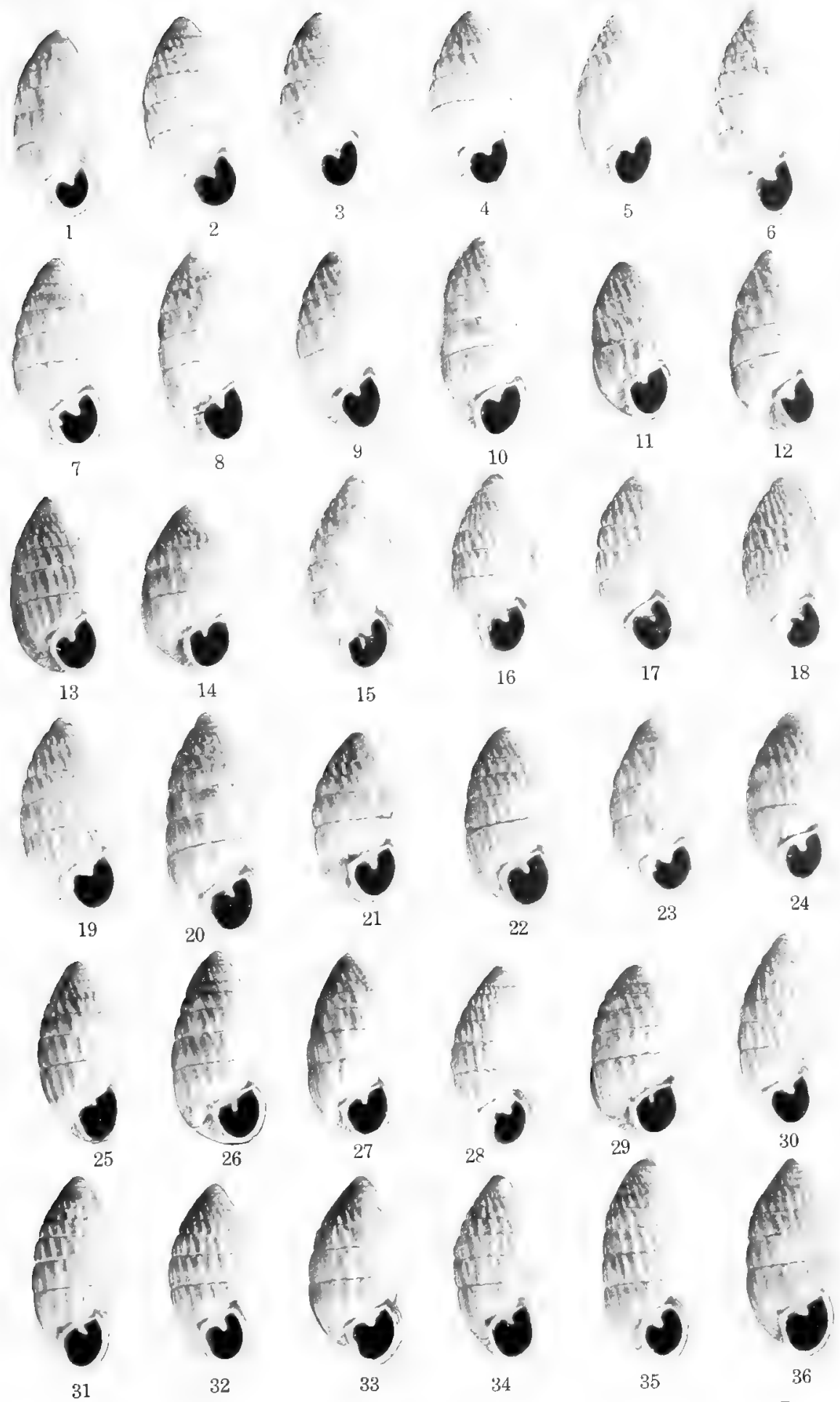

Figs. 1-36. First generation of Florida-grown Cerion casablancee from Colony B on Loggerhead Key, 1916. 



\section{Bunrscen}

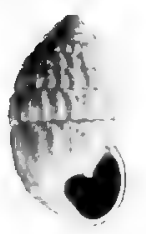

37

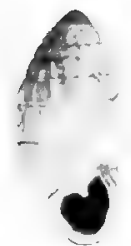

43

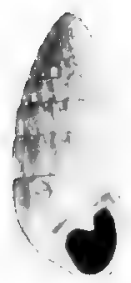

49

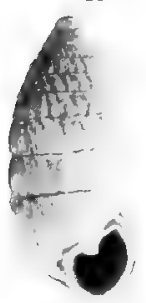

55

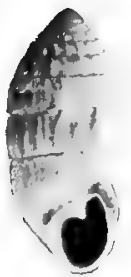

61
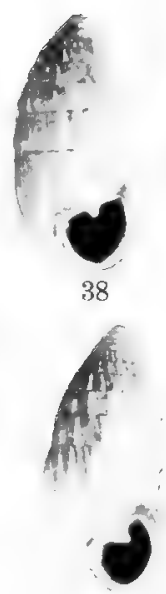

44

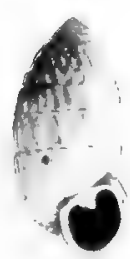

50

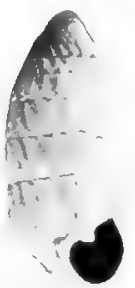

56

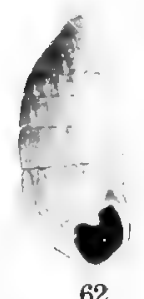

62

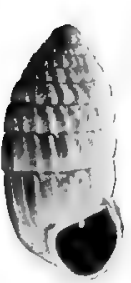

67

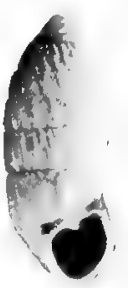

68

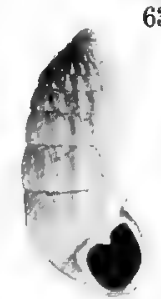

69

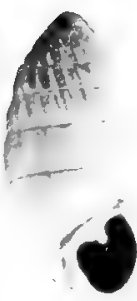

39

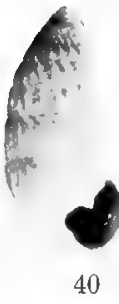

40

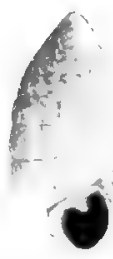

46

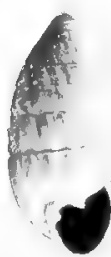

52

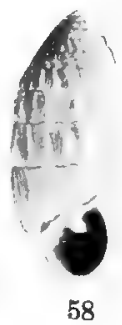

58

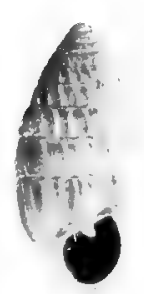

68

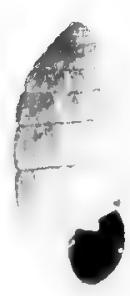

64
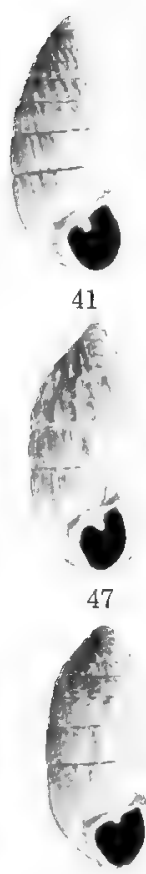

53
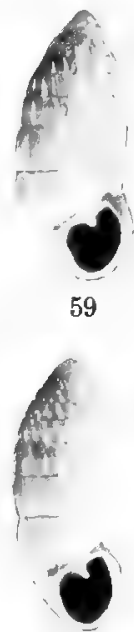

65

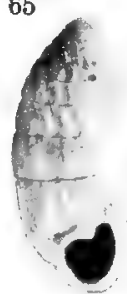

72
PLATE 43

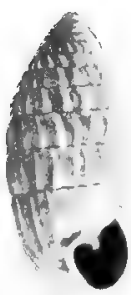

42

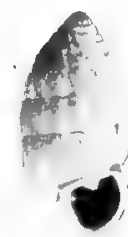

48

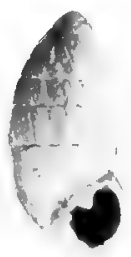

54

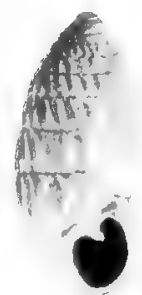

60

FIGS. 37-73. First generation of Florida-grown Cerion casablanca from Colony $\mathrm{B}$ on Loggerhead Key. 1916. 



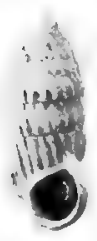

1
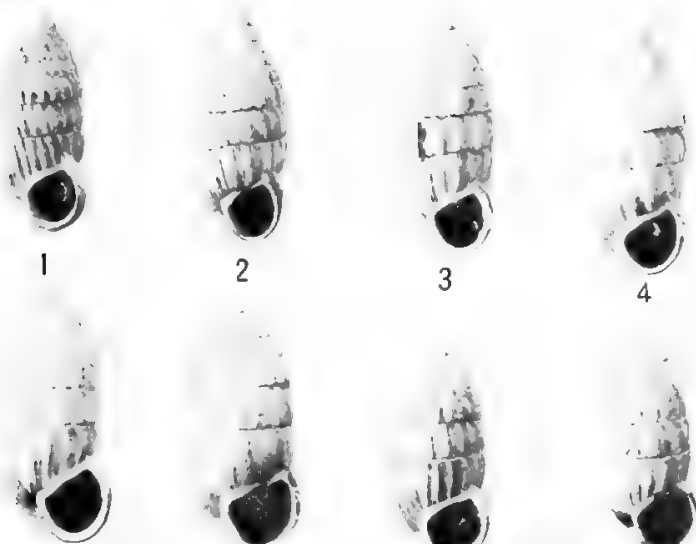

7

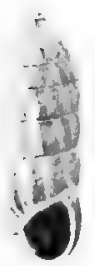

13

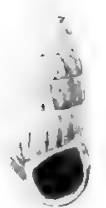

19

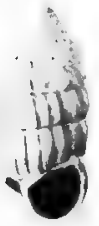

25

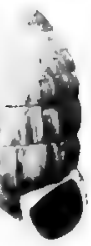

31

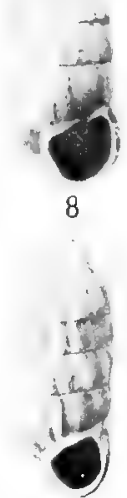

14

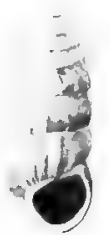

20

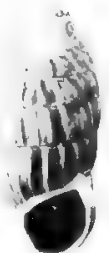

26
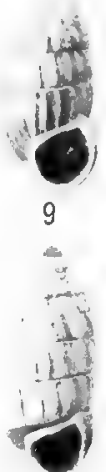

15

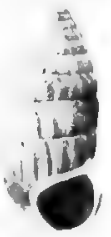

21

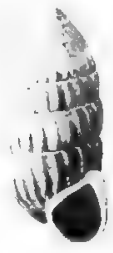

27

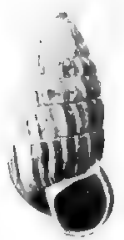

32

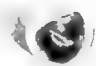

33
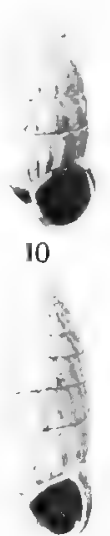

16

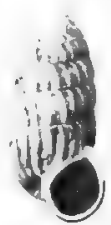

22

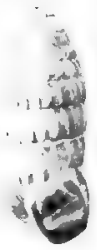

28
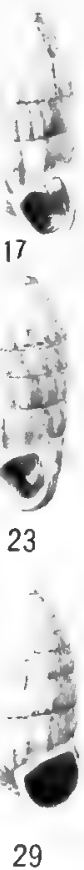

17

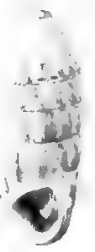

23

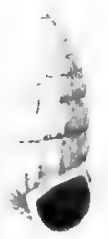

29

30

Fics. 1-36. First generation of Florida-grown Cerion casablanca from Colony C on Loggerhead Key. 1915. 



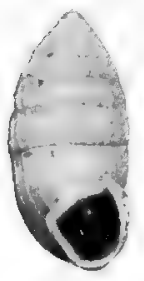

1

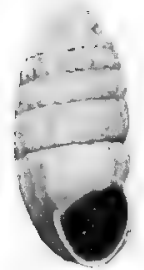

7

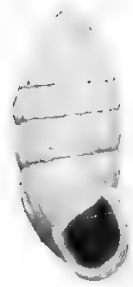

13

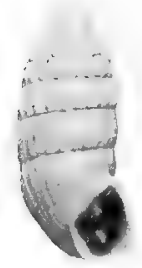

19

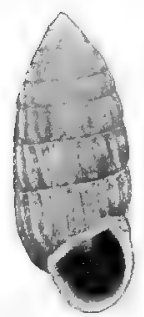

25
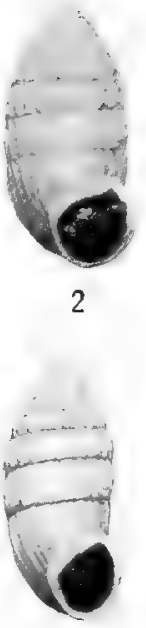

8

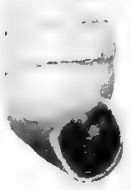

14

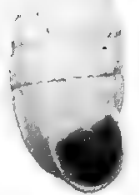

15

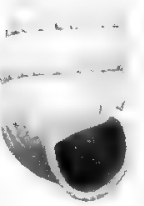

16

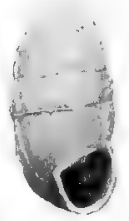

21

20
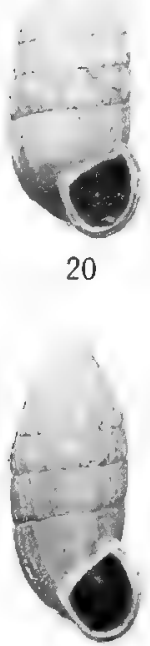

26

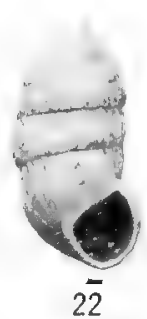

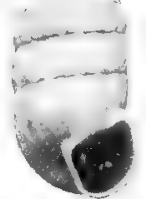

11

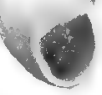

6

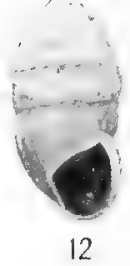

12

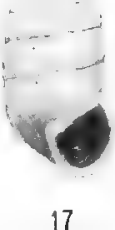

17

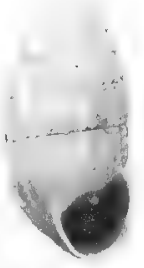

18
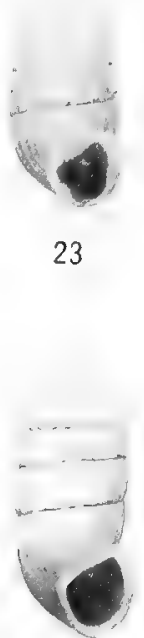

29

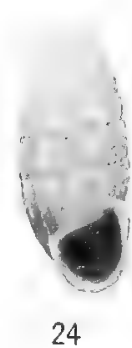

FIGs. 1-30. Second generation of Florida-grown Cerion casablance, from Colony C on Loggerhead Kiey. 



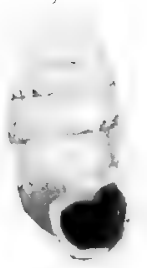

31

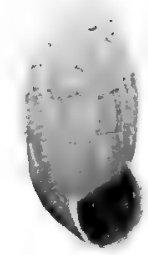

32

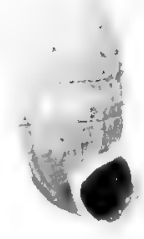

33

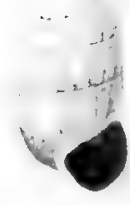

35

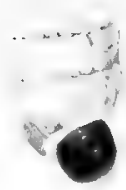

36

34

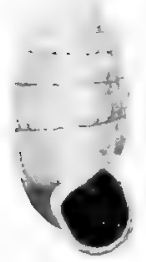

37

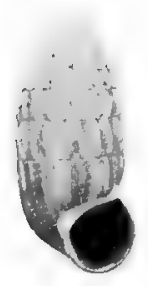

43

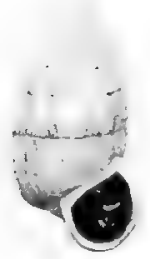

49

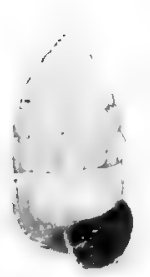

55

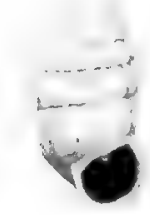

38

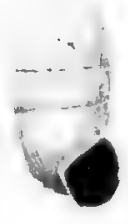

39

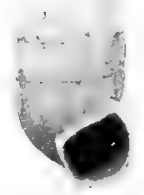

40

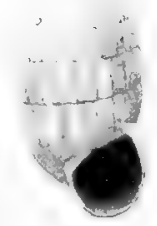

45

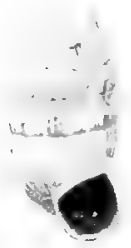

51

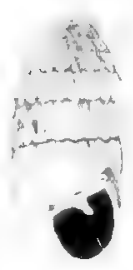

57

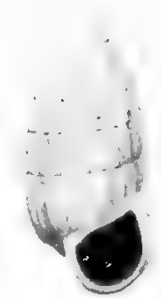

46

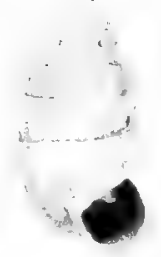

52

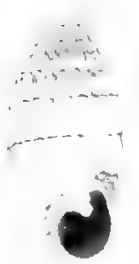

58

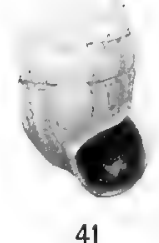

41

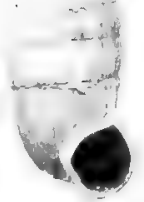

42

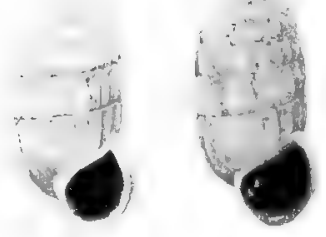

47

FIGS. 31-60. Second generation of Florida-grown Cerion casablance from Colony C on Loggerhead Key. 



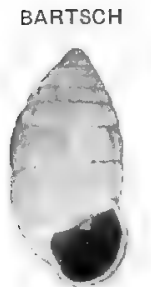

61

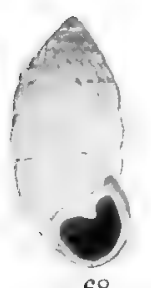

68

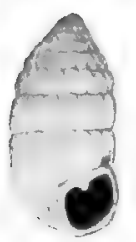

75
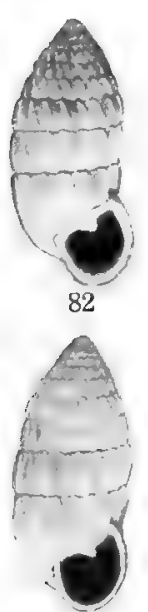

89

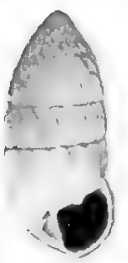

95

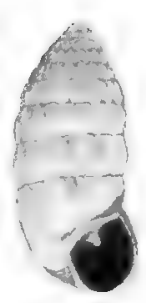

62

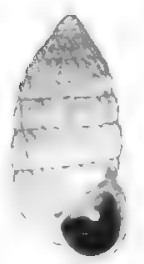

69

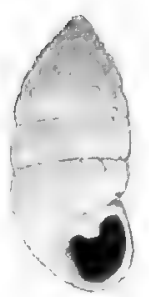

63

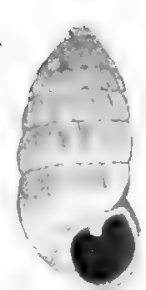

64
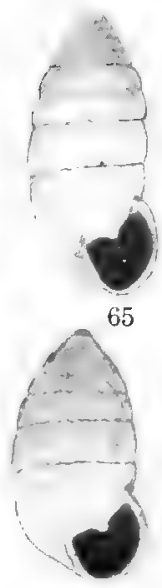

72
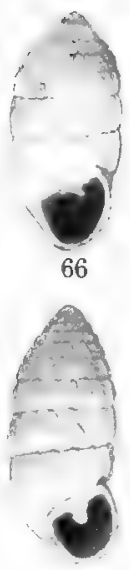

73

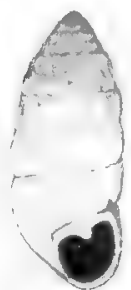

80
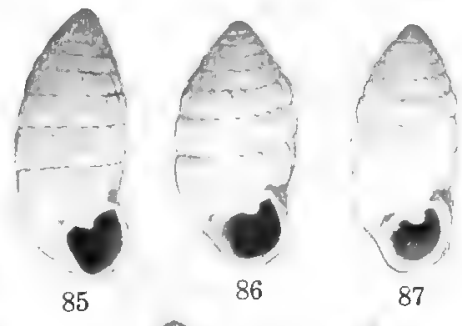

87

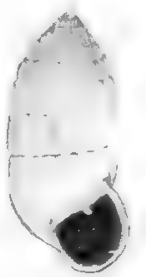

93

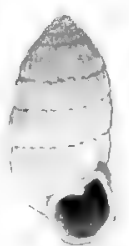

99

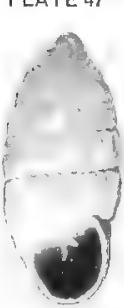

67

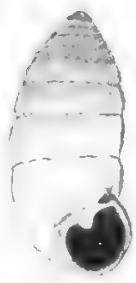

74

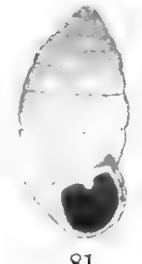

81

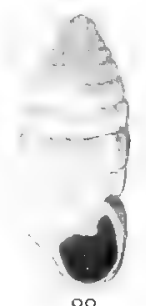

88

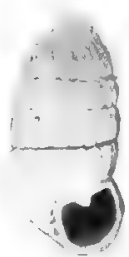

94

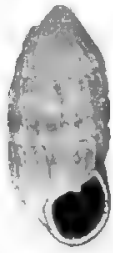

100

Figs. 61-100. Second generation of Florida-grown Cerion casablance from Colony C on Loggerhead Key. 



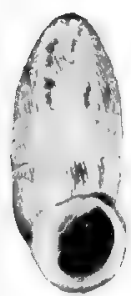

1

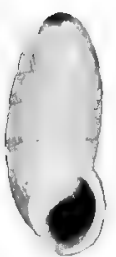

7

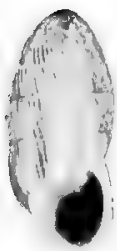

12

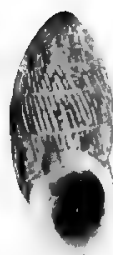

19

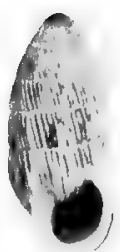

25

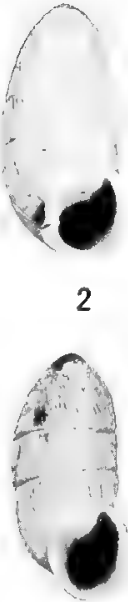

8

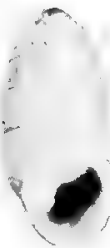

14

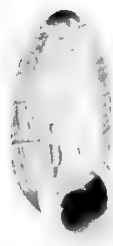

20

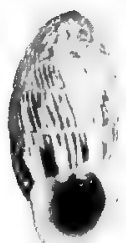

26

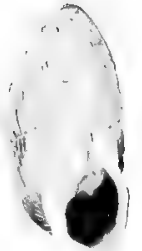

3

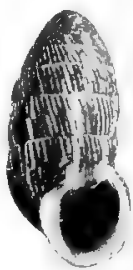

9

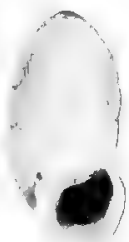

15

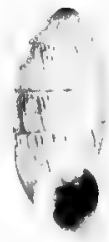

21

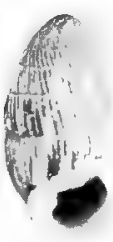

27

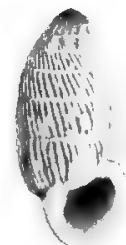

33

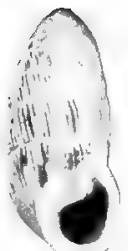

4

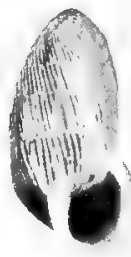

10

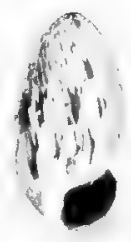

16

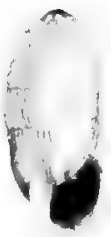

22

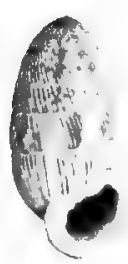

28

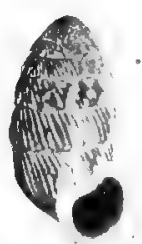

34

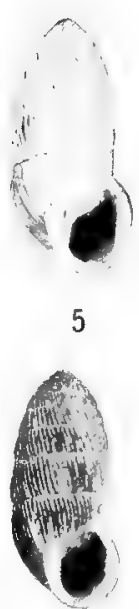

11

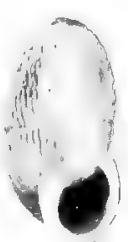

17

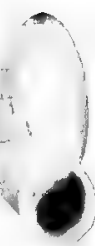

23
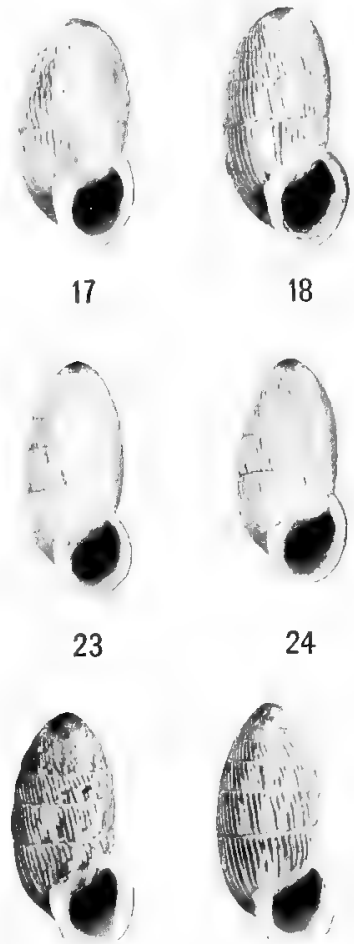

30
12

18

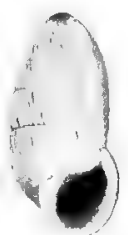

24

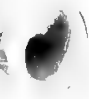

6

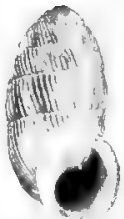

8
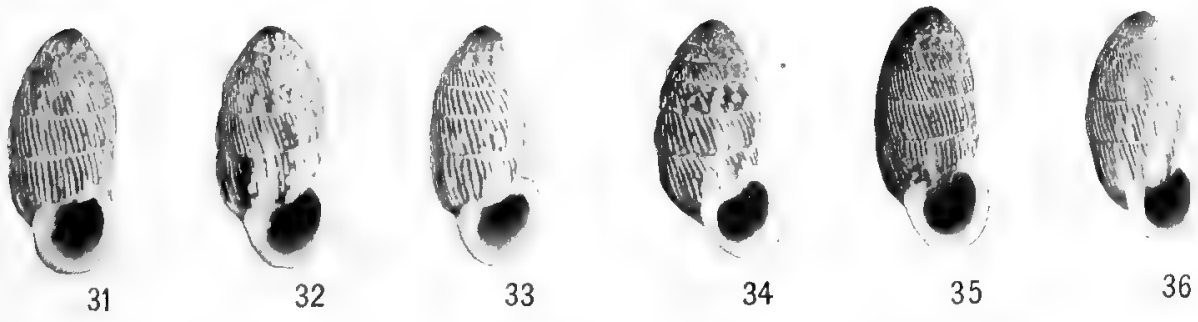


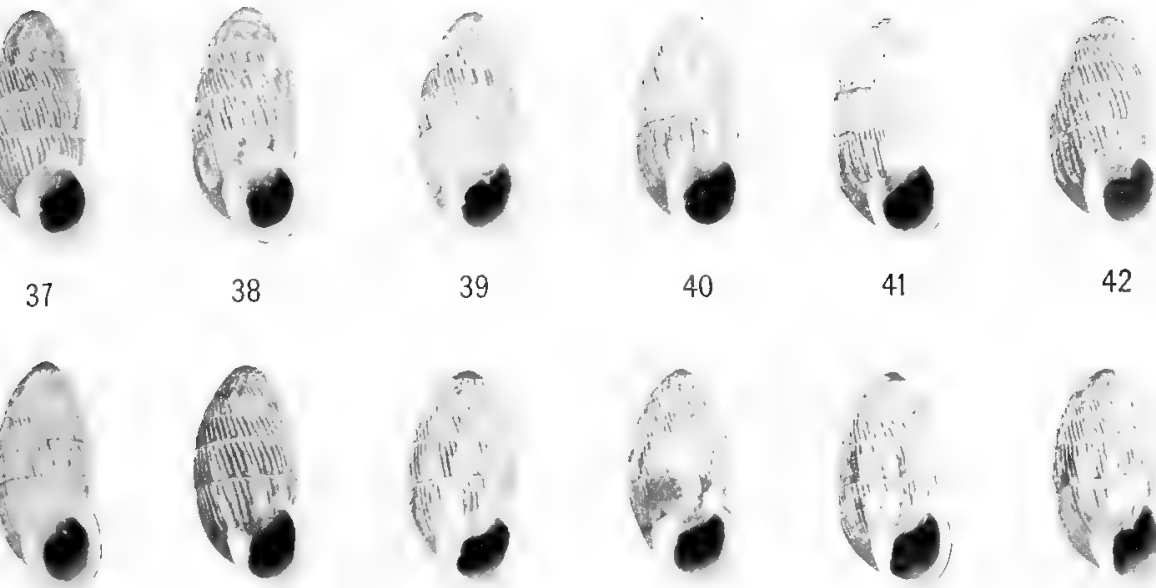

38

39

40

41

42
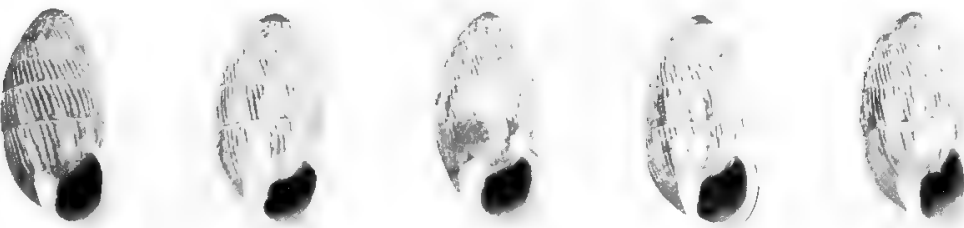

43

44

45

46

47

48
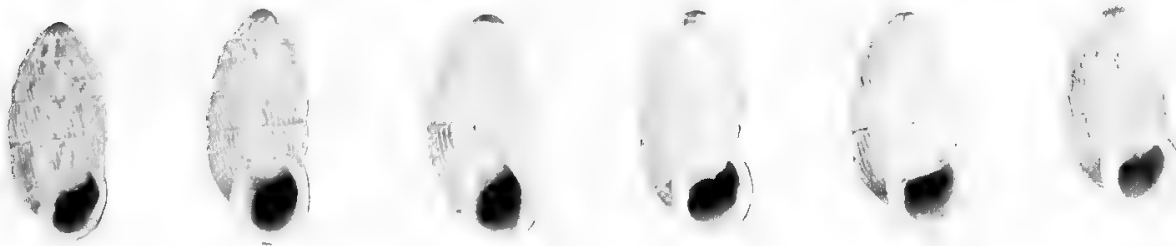

49

50

51

52

53

54
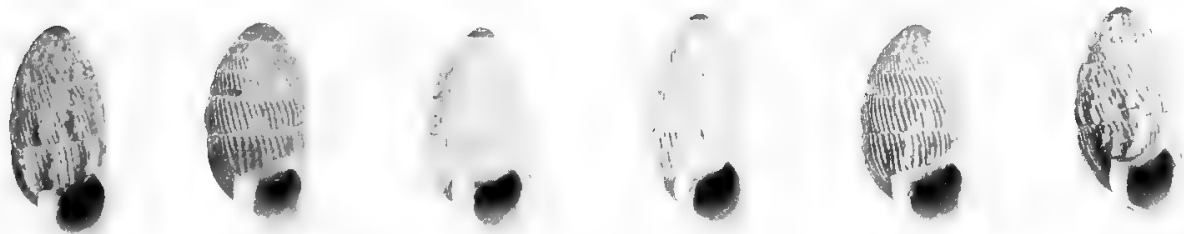

55

56

57

58

59

60
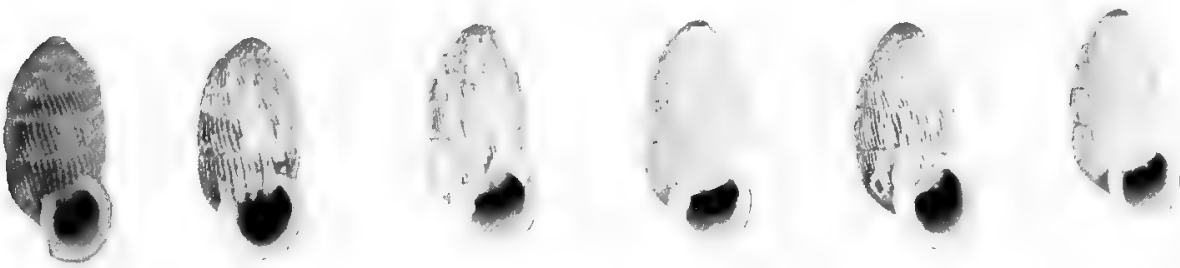

61

62

63

64

65

66
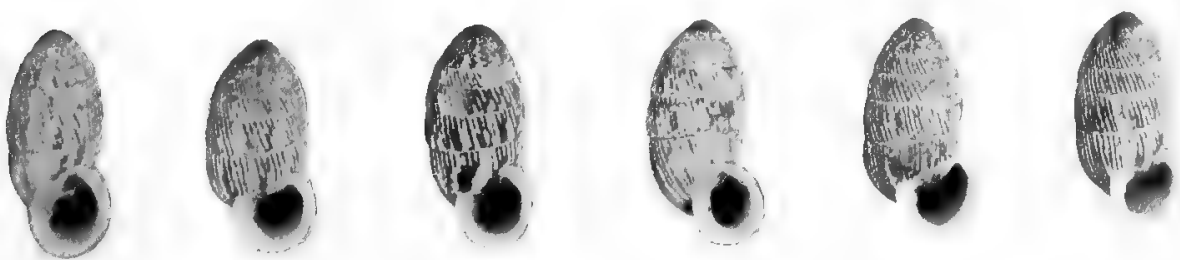

Fras. 37-72. Check series of Cerion crassilabris. 



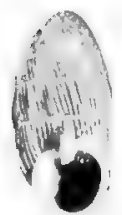

73

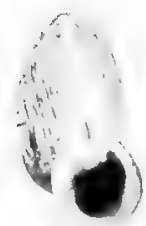

79

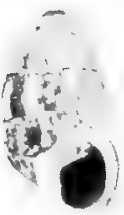

85

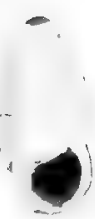

91

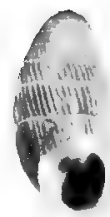

74

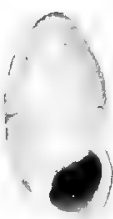

80

81

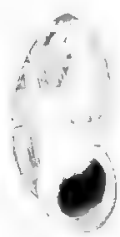

87

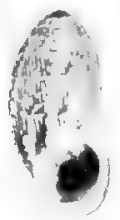

93

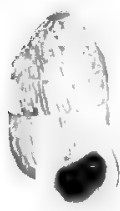

98

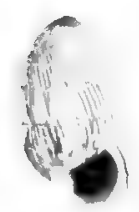

97

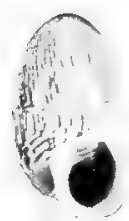

76

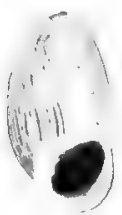

82

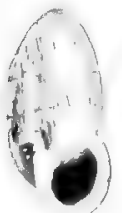

88

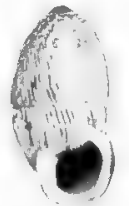

94

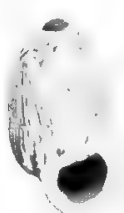

99

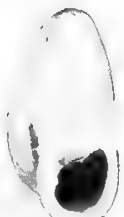

77

78

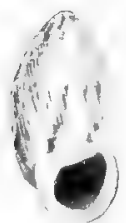

83

84
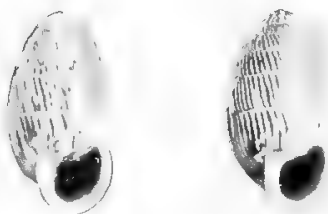

89

90
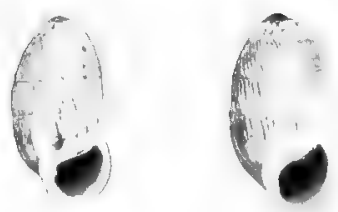

96

Figs. 73-100. Check series of Cerion crassilabris. 



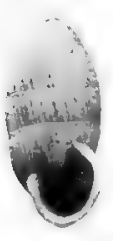

1

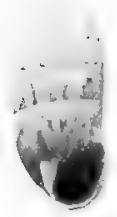

8

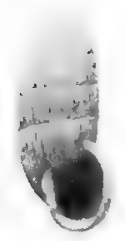

15

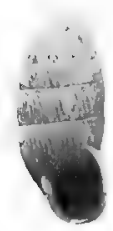

22

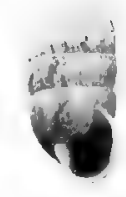

2

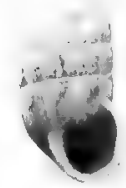

9

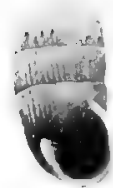

3

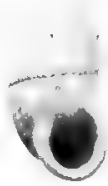

10

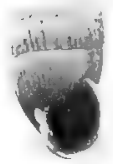

16

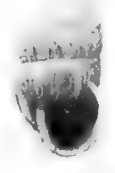

17

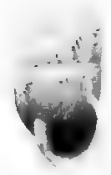

4

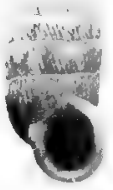

11

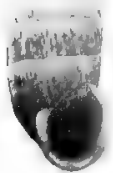

18

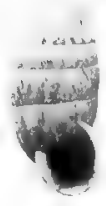

24

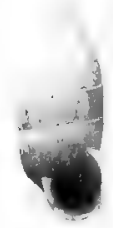

25

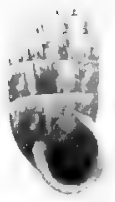

5

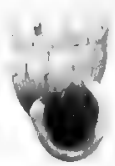

12

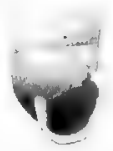

19

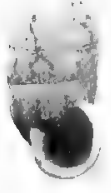

32

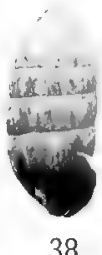

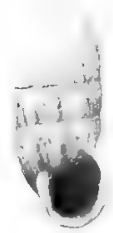

26

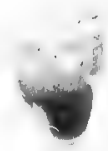

33

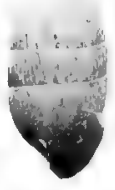

39

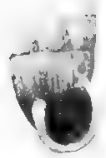

6

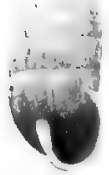

7

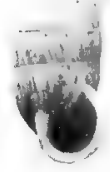

13

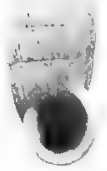

14

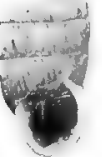

21

20
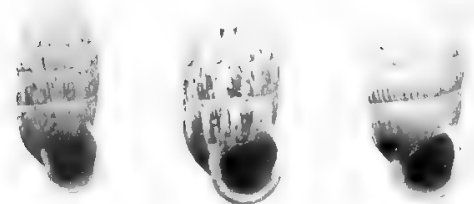

31

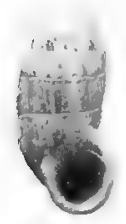

36

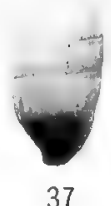

37
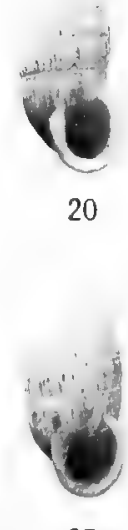

27

28

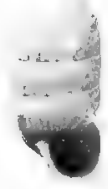

34
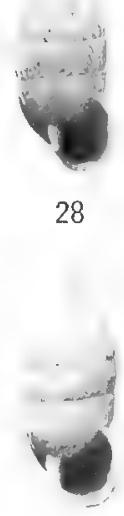

35

FIGs. 1-40. First generation of Florida-grown Cerion crassilabris, from Colony L on Loggerhead Kiey. 


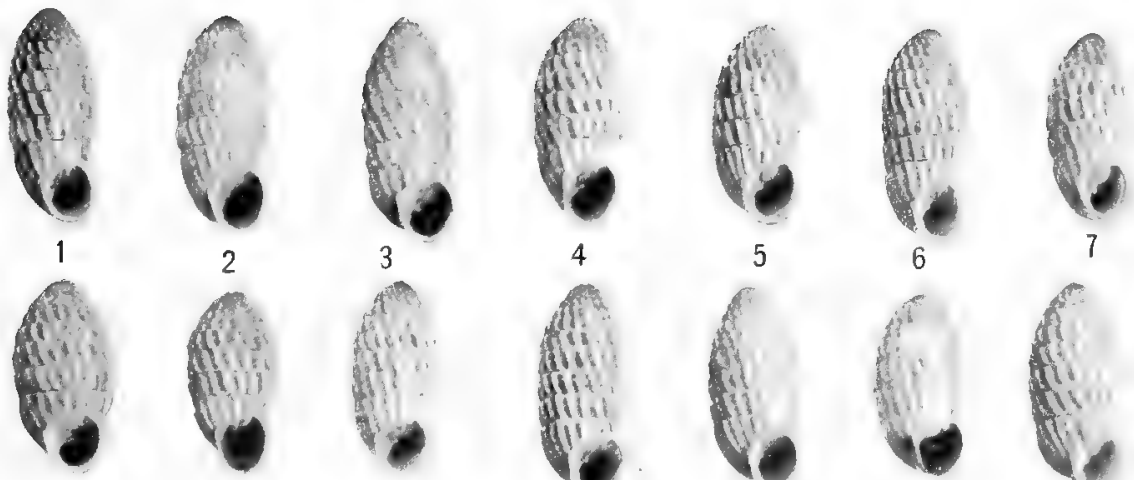

3

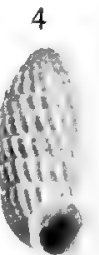

5

6

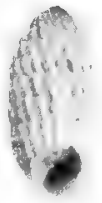

10
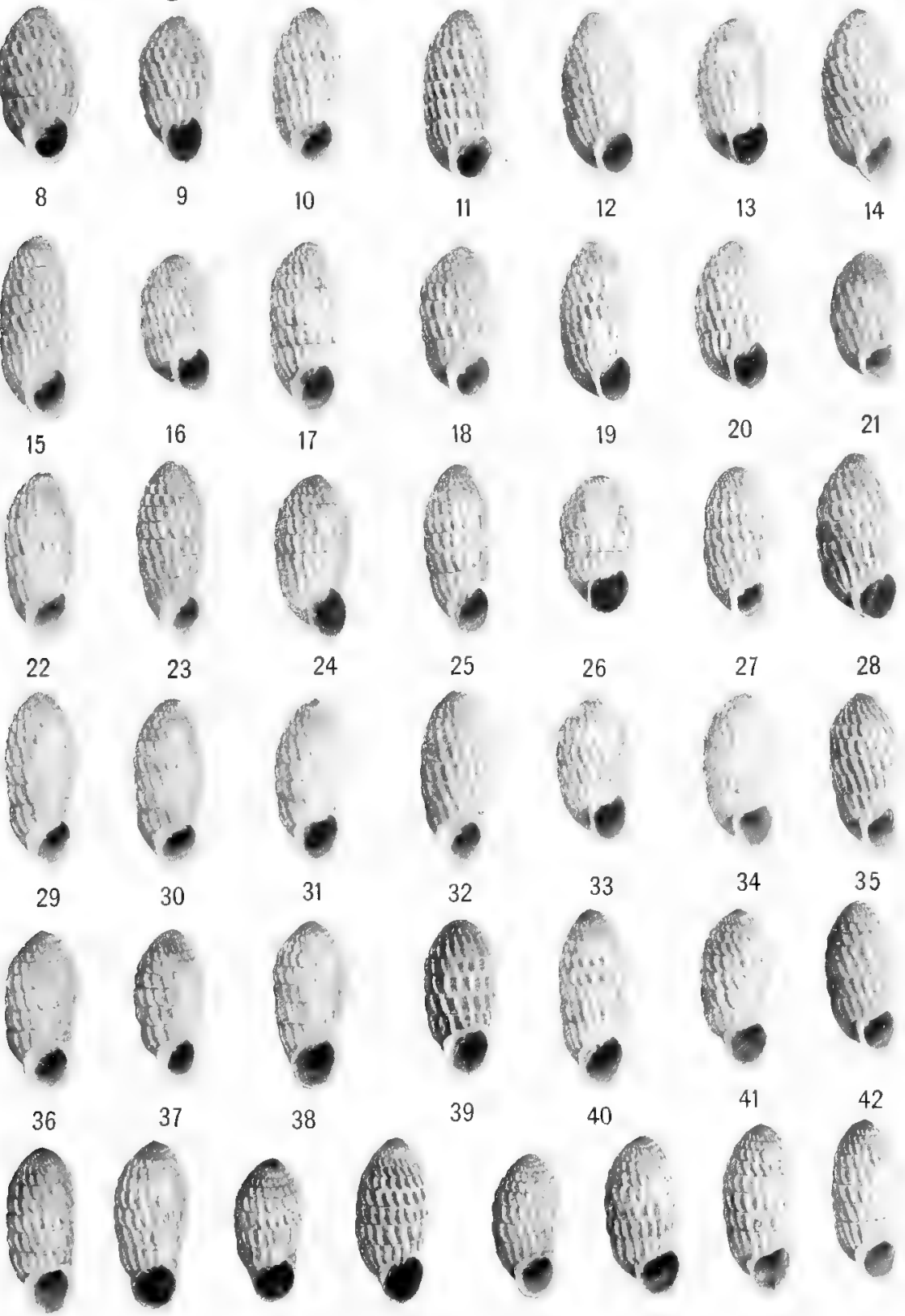

38

39

43

44
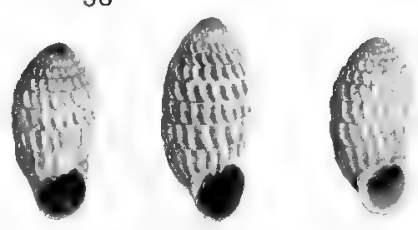

40

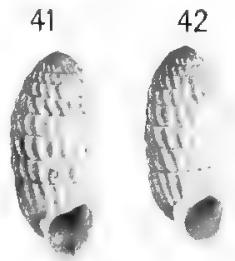

45

46

47

49

Figs.1-50. Check series of Cerion uva. 


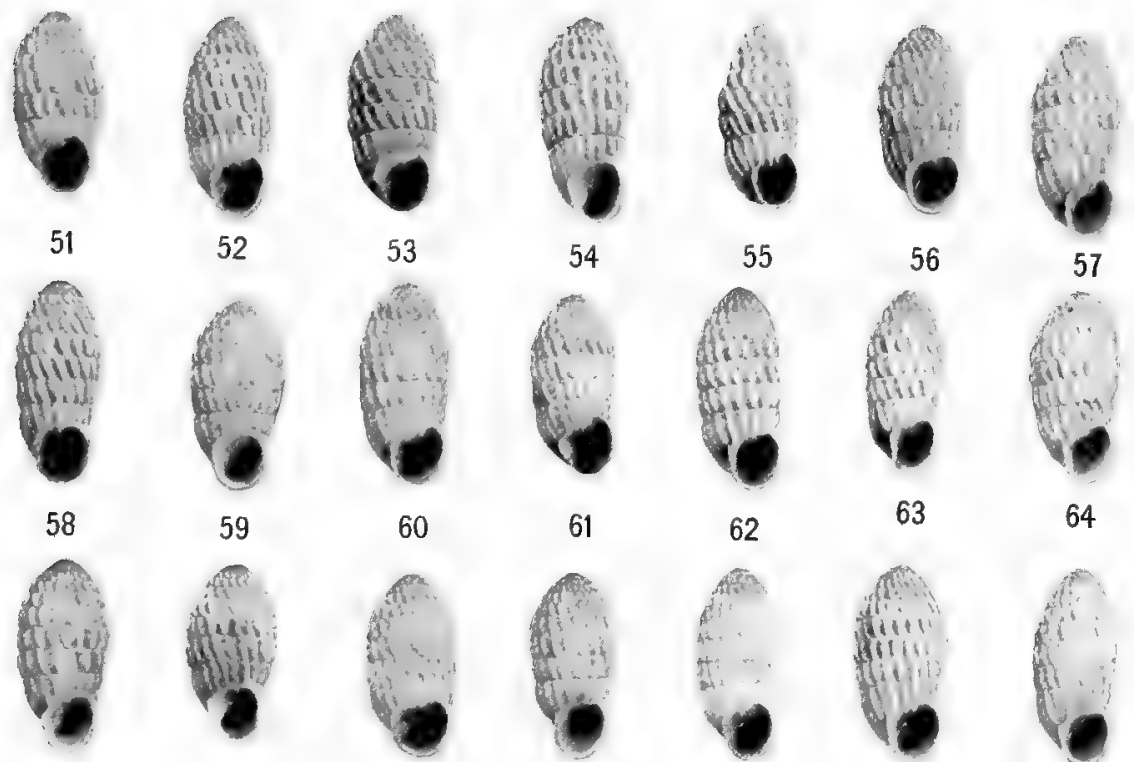

65

66
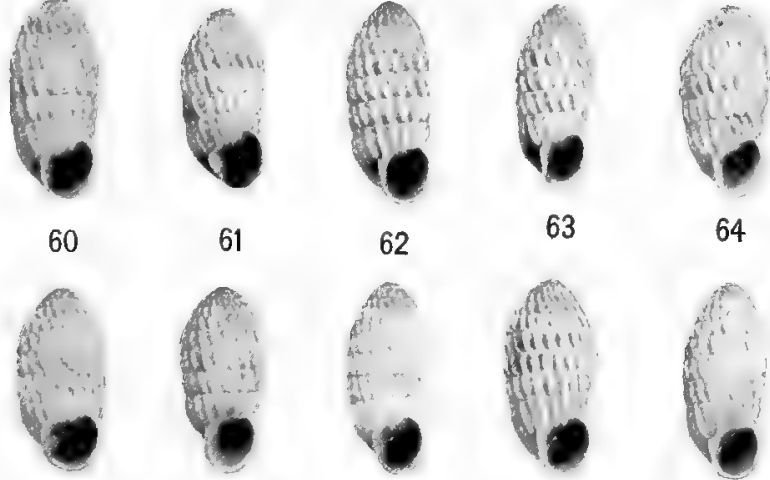

64
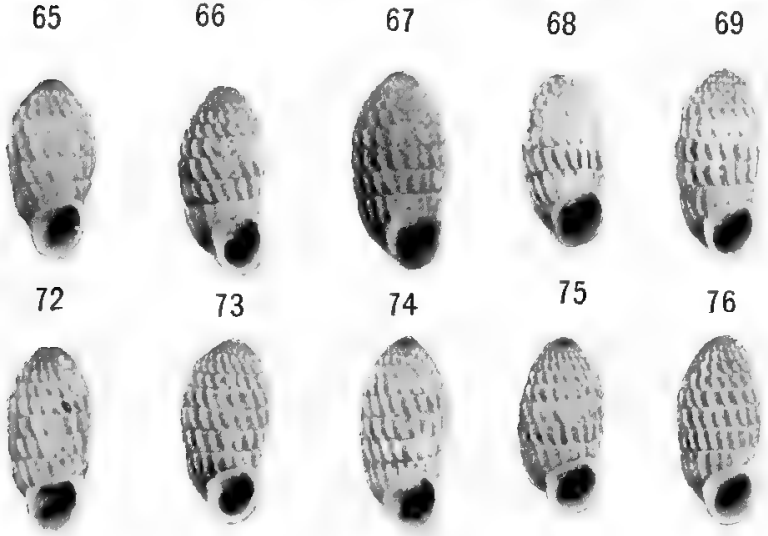

76
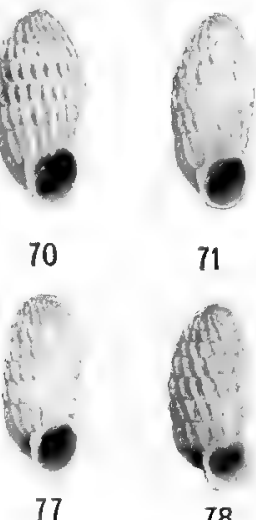

79
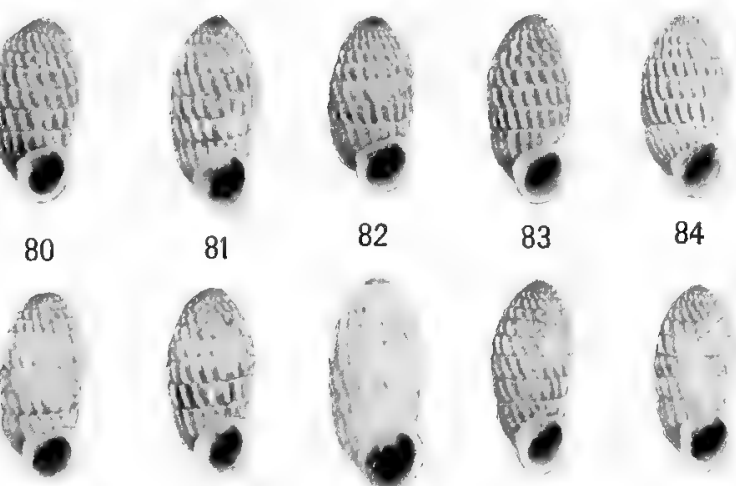

83

84
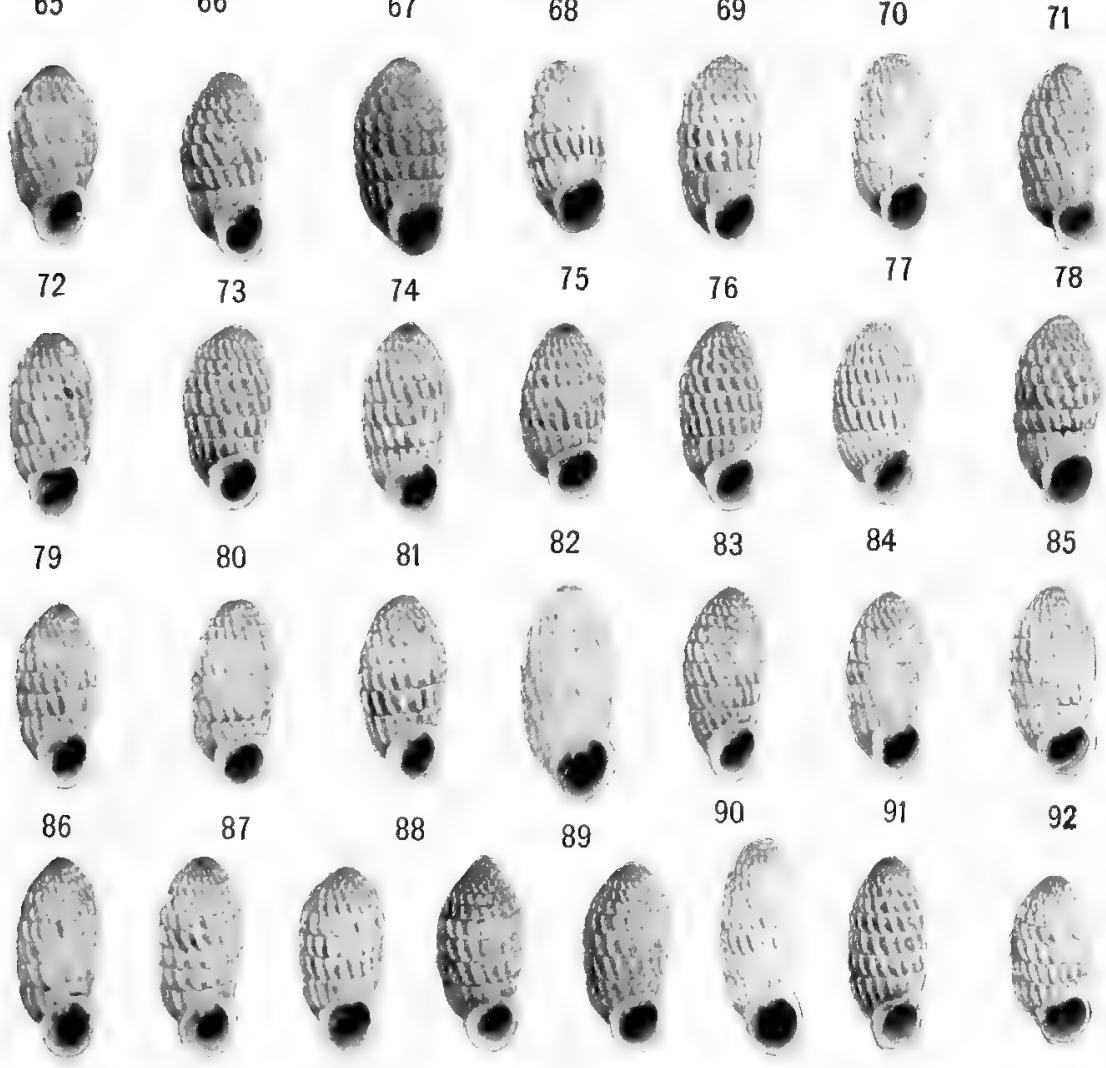

88

89

90

91

92
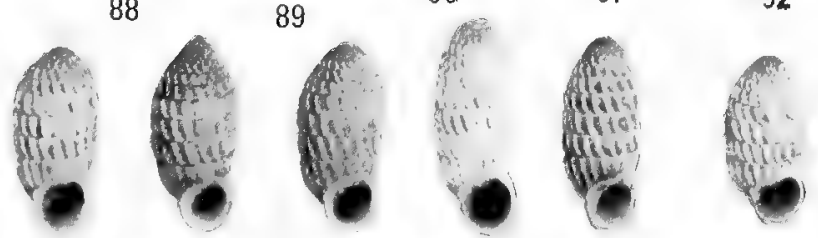

95

96

97

98

99

100

Figs. 51-100. Check series of Cerion uva. 


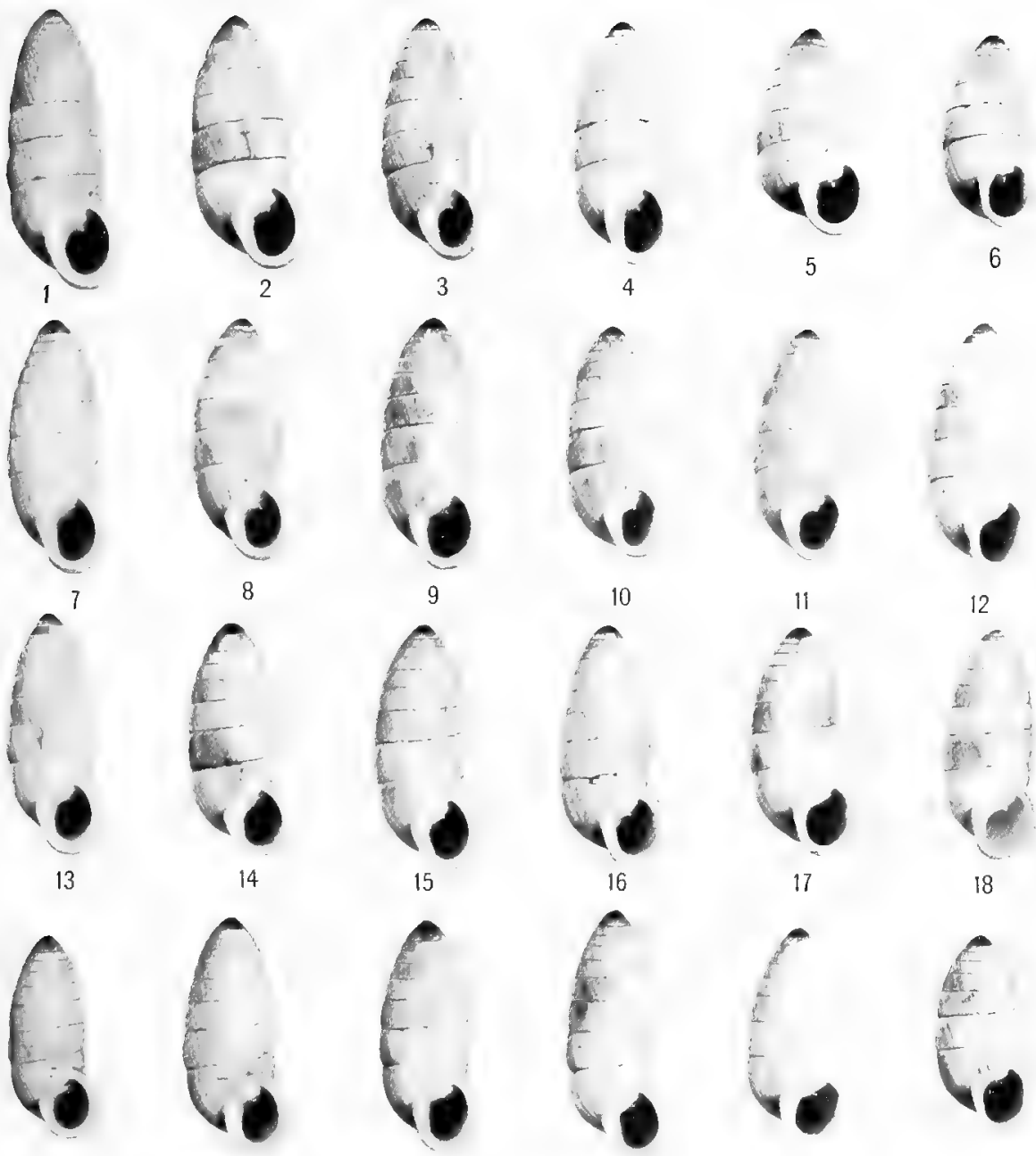

18
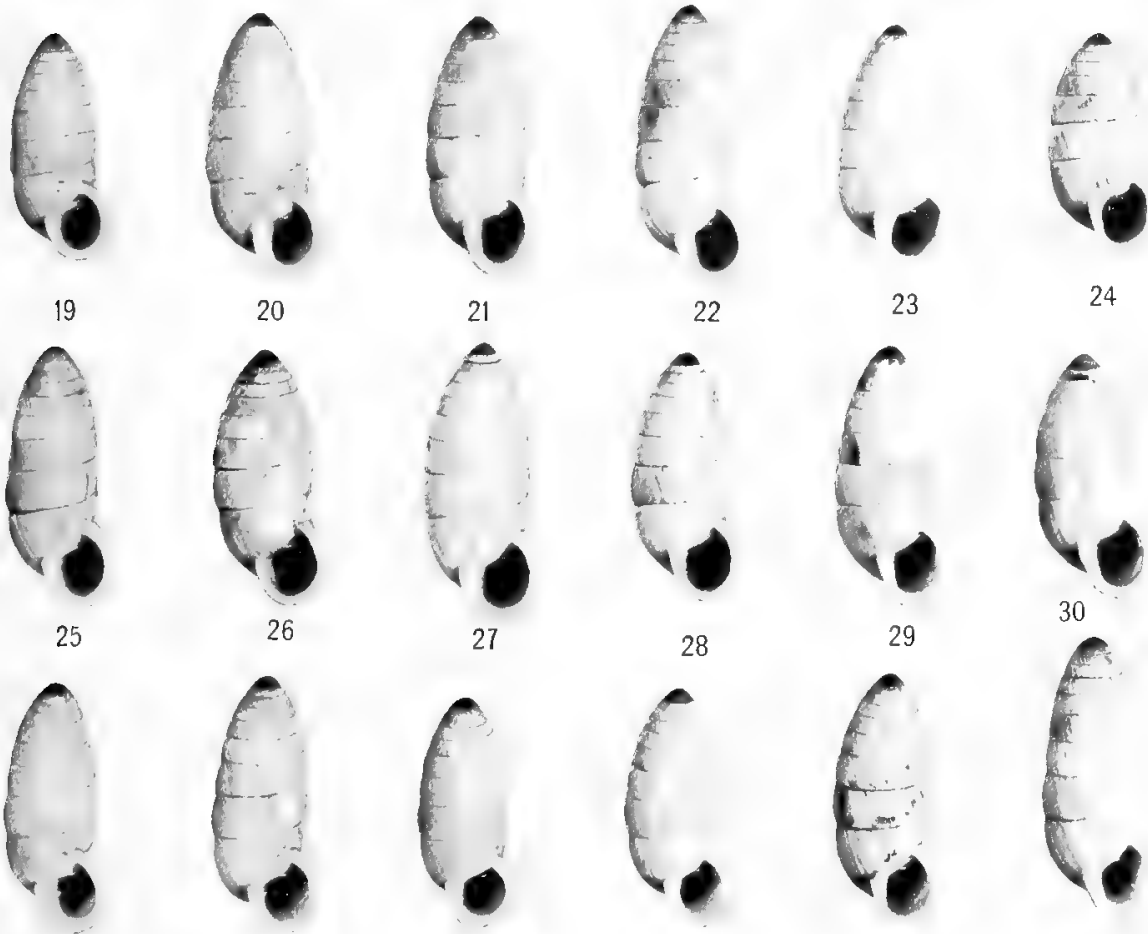

32
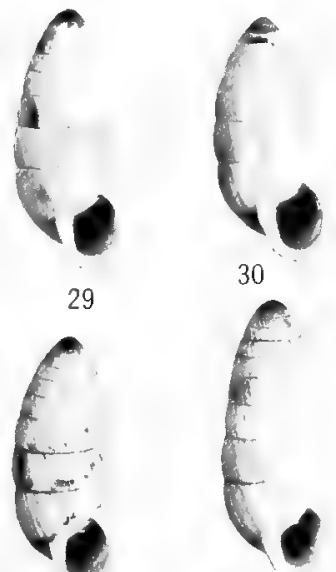

FIgs. 1-36. Check series of Cerion incanum. 



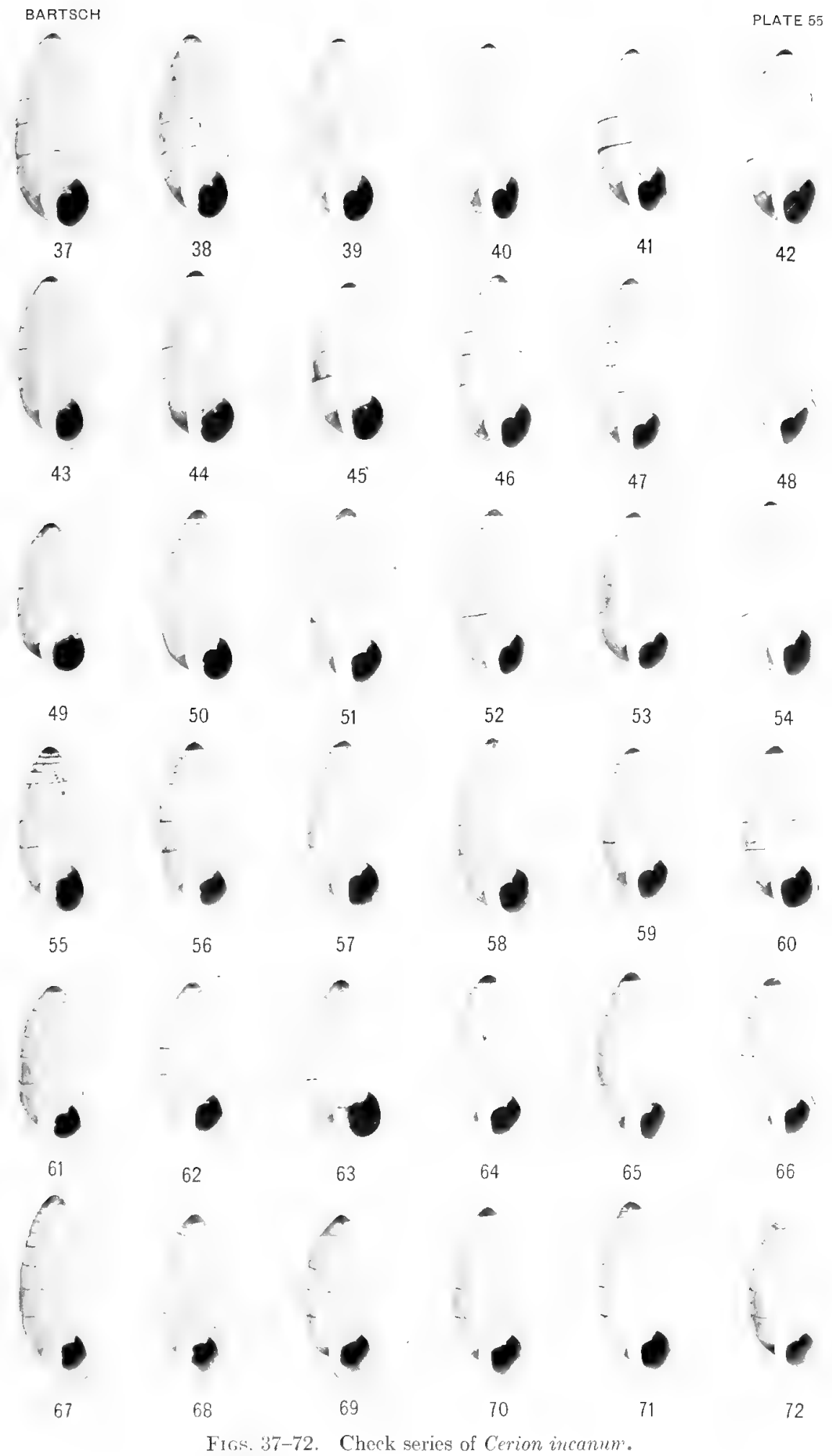





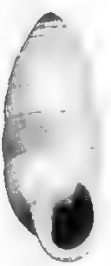

73

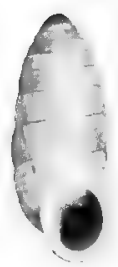

79

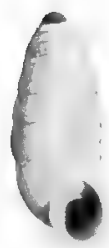

85

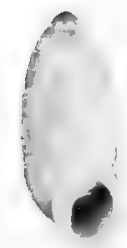

91

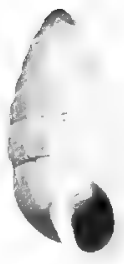

74

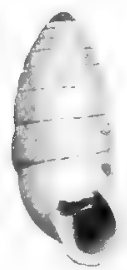

80

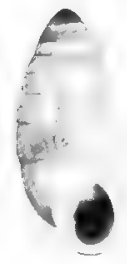

86

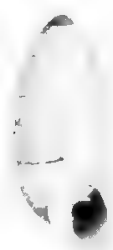

92

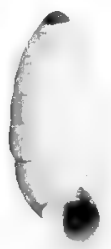

97

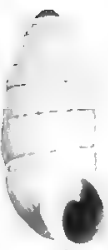

75

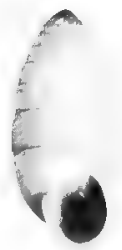

81

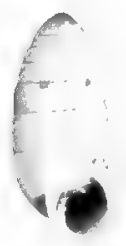

87

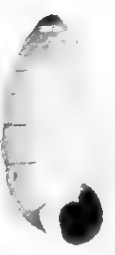

93

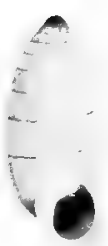

98

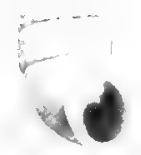

76

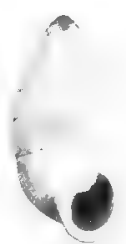

82

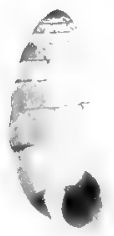

88

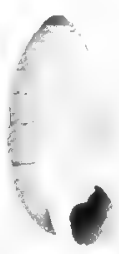

94

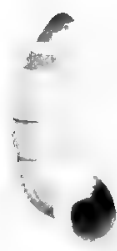

99

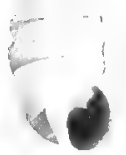

77

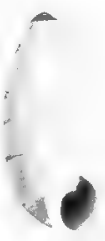

83

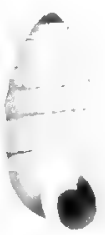

89

90

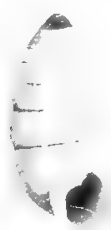

95

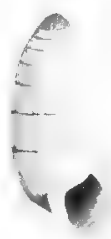

100

FIGs. 73-100. Check series of Cerion incanum. 



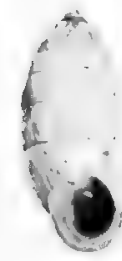

1

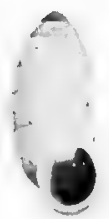

8
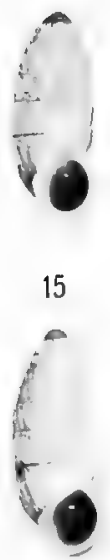

22

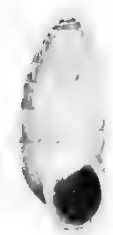

29

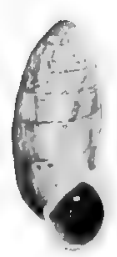

36

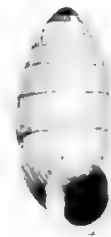

2

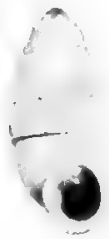

9

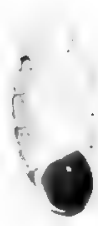

16

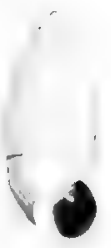

23

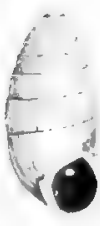

30

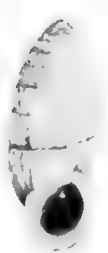

37

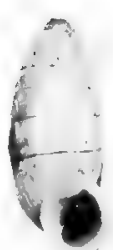

3

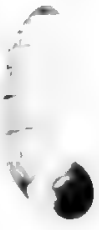

10

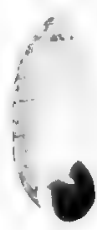

17

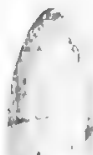

(o

24
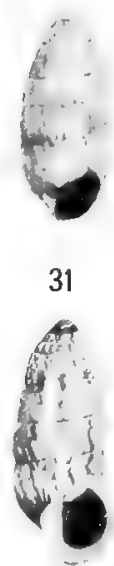

38

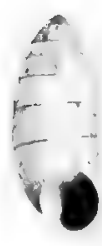

4

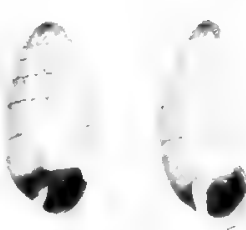

12

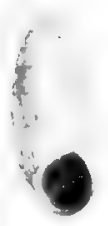

19

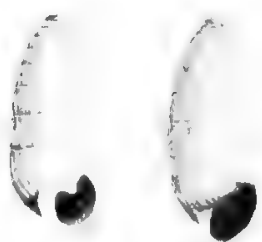

27

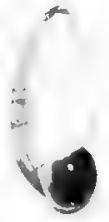

20

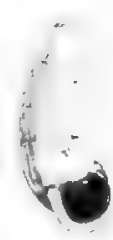

25
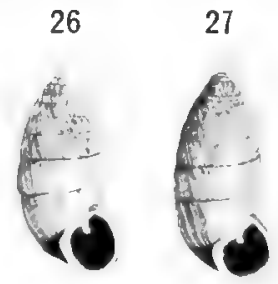

34

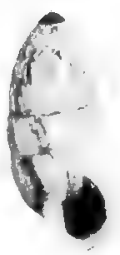

41

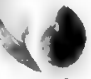

7

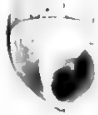

14

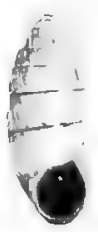

21

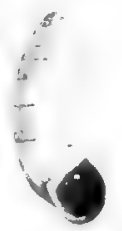

28

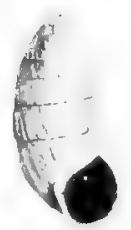

35

Frgs. 1-42. Cerion incanum $\times$ Cerion viaregis from Newfound Harbor Key. 



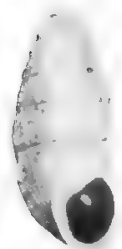

43

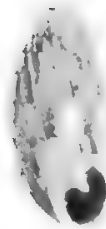

50

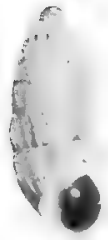

57

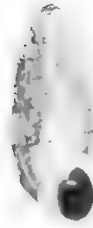

64

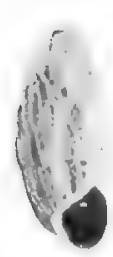

71

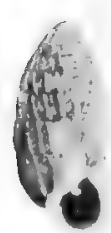

78

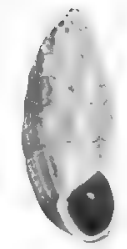

44

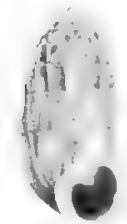

51

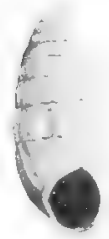

58
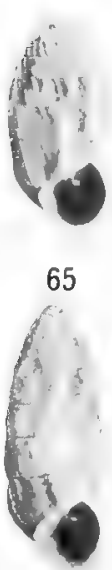

72

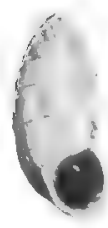

45

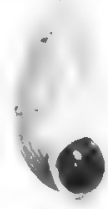

52

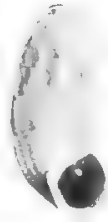

59

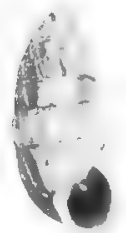

66
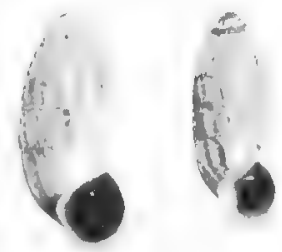

74

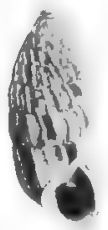

81

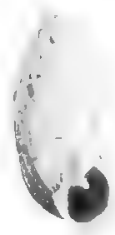

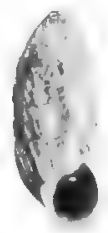

80

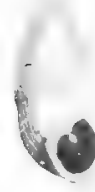

47
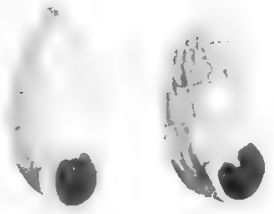

55

56
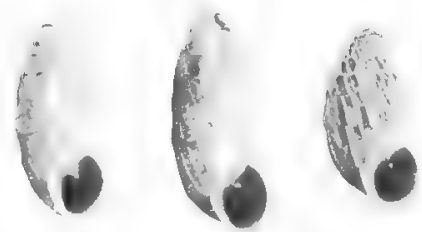

62

63
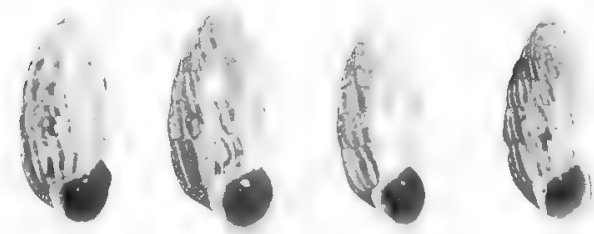

68

69

70
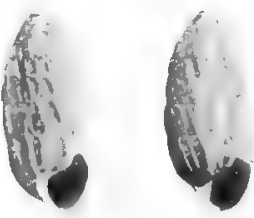

76

77

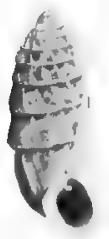

79

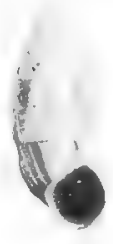

75

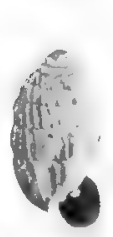

82

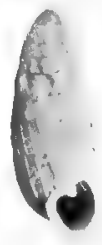

83

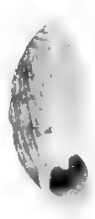

84

Figs. 43-84. Cerion incanum $\times$ Cerion viaregis from Newfound Harbor Key. 



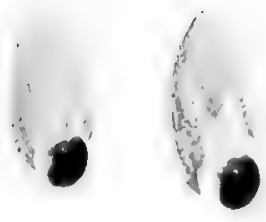

85

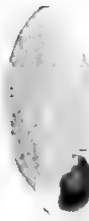

92

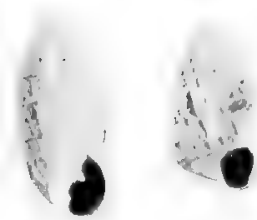

99

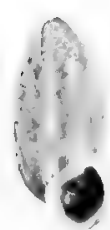

106

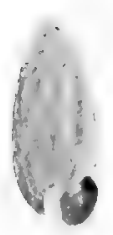

113

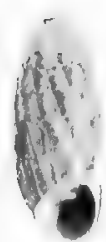

120

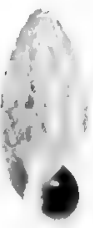

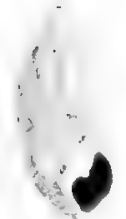

87

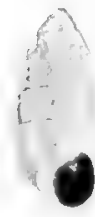

94

93

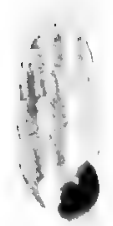

88

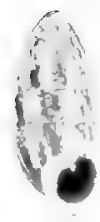

89

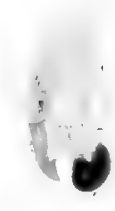

90

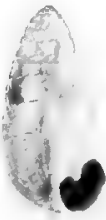

96

95

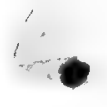

102
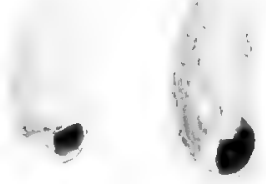

103

104
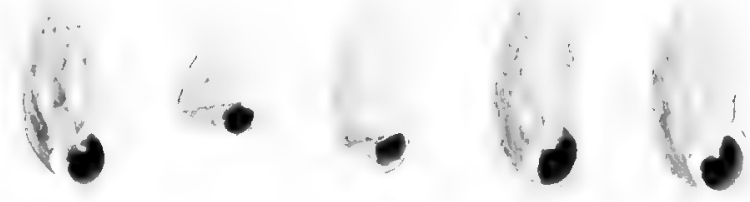

101

105
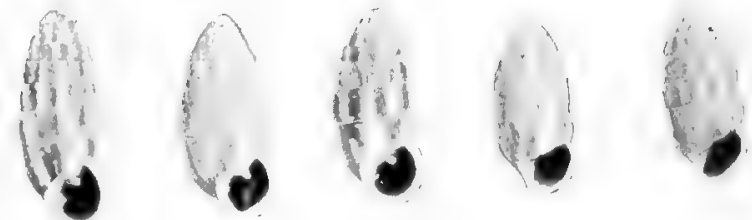

109

111

112
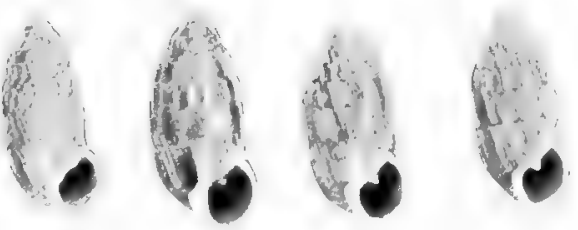

115

116

117

118

119
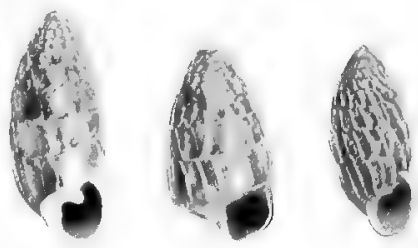

123

124

125

FIGS. 85-125. Cerion incanum $\times$ Cerion viaregis from Newfound Harbor Key. 








